UNIVERSIDADE DE BRASÍLIA INSTITUTO DE GEOCIÊNCIAS

\title{
ANÁLISE GEOQUÍMICA, MICROBIOLÓGICA E SUAS IMPLICAÇÕES EM ESTUDOS AMBIENTAIS NO RIO DAS ANTAS-GO
}

CRISTIANE APARECIDA DE OLIVEIRA

Dissertação de Mestrado $\mathbf{n}^{\circ} 074$ 


\title{
UNIVERSIDADE DE BRASÍLIA
} INSTITUTO DE GEOCIÊNCIAS

\section{ANÁLISE GEOQUÍMICA, MICROBIOLÓGICA E SUAS IMPLICAÇÕES EM ESTUDOS AMBIENTAIS NO RIO DAS ANTAS-GO}

\author{
CRISTIANE APARECIDA DE OLIVEIRA
}

Dissertação de Mestrado $n^{\circ} 074$

Orientador:

Prof. Dr. Geraldo Resende Boaventura (Orientador- IGD/UnB)

Banca Examinadora:

Prof. Dr. Luciano Soares da Cunha (IGD/UnB)

Prof. Dr. Éder de Souza Martins (EMBRAPA) 


\section{AGRADECIMENTOS}

A Deus pela oportunidade que me concedeu de alcançar mais esta vitória. À minha família e às Irmãs Oblatas do Menino Jesus pela força, incentivo constante, amor e carinho recebidos no decorrer de toda a trajetória desta pesquisa.

Ao Professor Dr. Geraldo pelo apoio e competência em orientar minhas habilidades e sua confiança em minha capacidade para a execução deste trabalho e aos integrantes da comissão avaliadora Dr. Éder e Dr. Luciano que gentilmente aceitaram o convite, trazendo contribuições relevantes para o aprimoramento desta Dissertação.

Ao Programa de Pós-Graduação em Geociências Aplicadas da Universidade de Brasília na pessoa do Dr. José Eloi pela oportunidade e incentivo de ingressar neste curso e progredir em meus estudos e aos docentes que contribuíram para meu aperfeiçoamento à pesquisa.

Aos técnicos do Laboratório de Geoquímica da UnB, Myller e Fernando pelo auxílio nas análises geoquímicas das amostras e à Prof. ${ }^{a}$ Edi do Laboratório de Difratometria de Raio-X da UnB, pelo subsídio na análise mineralógica das amostras de sedimento de fundo e interpretação dos resultados.

À CAPES, CNPQ, Secretaria de Estado da Educação de Goiás e à SANEAGO/GO pelos auxílios financeiros essenciais à execução e divulgação deste trabalho. À Secretaria do Meio Ambiente de Anápolis/GO na pessoa do professor Neivaldo e ao Wellington Barcelo (SANEAGO) pela ajuda na realização das coletas realizadas nos trabalhos de campo.

Às minhas amigas Érika e Leila pela contribuição prestada à minha Dissertação e também minha amiga Carla Jovânia pelo incentivo em me ingressar no curso de Mestrado da UnB. Enfim, agradeço a todas as pessoas que, de forma direta ou indireta tenha contribuído para a realização e conclusão desta Dissertação de Mestrado.

A todos, meu muito Obrigado! 


\section{RESUMO}

A qualidade da água é resultante das condições geológicas e alterações procedentes do uso e ocupação do solo. O estudo da qualidade da água e sedimentos de fundo representa importante meio de vinculação entre a geoquímica das rochas, solos e substâncias lançadas pelo homem nos ecossistemas terrestres e aquáticos. Na presente pesquisa realizou-se estudo geoquímico do Rio das Antas-GO com objetivo de avaliar a qualidade da água por meio dos parâmetros físico-químicos e microbiológicos. Para as análises das amostras utilizaram-se técnicas de ICP/OES, espectrofotometria UV/Visível e métodos volumétricos. A abertura das

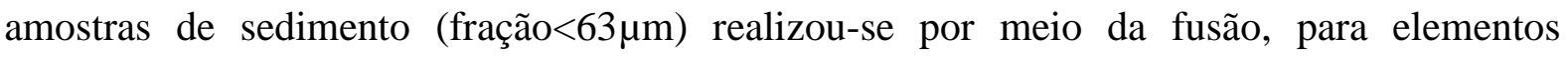
maiores, e ataque ácido para traço. A análise microbiológica foi obtida pela técnica dos tubos múltiplos com substrato enzimático. Para determinação do Oxigênio Dissolvido usou-se o método idométrico e Demanda Bioquímica de Oxigênio estipulou-se o consumo de oxigênio necessário para decompor a matéria orgânica. $\mathrm{Na}$ interpretação dos resultados foram utilizadas estatísticas multivariadas além de índice de geoacumulação. O estudo pôde determinar a fonte dos compostos na água, o Fe, $\mathrm{Al}, \mathrm{Mn} \mathrm{e} \mathrm{SO}_{4}{ }^{2-}$ originaram da oxidação dos sulfetos e pirita; $\mathrm{HCO}_{3}{ }^{-}, \mathrm{Ca}, \mathrm{K}, \mathrm{Mg}, \mathrm{Zn}, \mathrm{Ba}$, da dissolução de minerais dolomíticos e produtos agroquímicos como fertilizantes e inseticidas. Total de Sólidos Dissolvidos (TDS), $\mathrm{NH}_{3}$, $\mathrm{NO}_{3}{ }^{-}$e turbidez tiveram sua entrada por meio de esgotos domésticos. $\mathrm{PO}_{4}{ }^{3-}$ não foi encontrado em água, sendo adsorvido em sedimentos de fundo cuja principal responsável pela retenção foi a goethita e a caulinita. A correlação de Spearman revelou que, elevadas quantidades de bactérias coliformes $\left(9,4.10^{4}\right)$ correspondem às maiores quantidades encontradas de Escherichia Coli $\left(7,9.10^{4}\right)$ e Demanda Bioquímica de Oxigênio (7,00). O agrupamento hierárquico, interpretado juntamente com a análise mineralógica e o índice de geoacumulação possibilitou distinguir as influências ocasionadas pelos depósitos minerais na acumulação de metais nos sedimentos estudados. Obteve acumulação "forte a extremamente enriquecidos" o $\mathrm{MgO}, \mathrm{Mn}, \mathrm{Co}$ e Ba evidenciando a dissolução de rochas carbonáticas pelo aumento de $\mathrm{MgO}$ e diminuição de $\mathrm{CaO}, \mathrm{Na}_{2} \mathrm{O}, \mathrm{K}_{2} \mathrm{O}$. No nível "acumulação moderada" estão $\mathrm{SiO}_{2}, \mathrm{Fe}_{2} \mathrm{O}_{3}, \mathrm{Cu}$, $\mathrm{Ni}, \mathrm{Zn}$, Sr, e Cr. A acumulação do $\mathrm{SiO}_{2}$ e $\mathrm{Fe}_{2} \mathrm{O}_{3}$ demonstraram origem associada a silicatos de $\mathrm{Fe}$ e Al, como os argilominerais. Tais resultados possibilitaram a criação do modelo geoquímico que auxiliasse na identificação das fontes e distribuição dos elementos e metais presentes na água e sedimento de fundo da região estudada. 


\section{ABSTRACT}

Water quality is a result of geological conditions and changes coming from the use and occupation of land. The water quality study and bottom sediments is an important means of connection between the geochemistry of rocks, soils and substances discharged by man in terrestrial and aquatic ecosystems. In the present study, an important geochemical study was performed in Rio das Antas-GO in order to evaluate water quality through physical, chemical and microbiological parameters. For the analysis of samples, techniques such as ICP/OES, UV/Visible spectrophotometry and volumetric methods were use. The opening of sediment samples (fraction $<63 \mu \mathrm{m}$ ) was held by fusion, to major elements, and acid attack to trace. Microbiological analysis was obtained by the multiple tubes with enzyme substrate. For the determination of Dissolved Oxygen the idometric method and Biochemical Oxygen Demand were used and one stipulated the consumption of oxygen needed to decompose organic matter. By interpreting the results, one used multivariate statistical and also geoaccumulation index. The study was able to determine the source of the compounds in water, $\mathrm{Fe}, \mathrm{Al}, \mathrm{Mn}$ and SO42- originated from the oxidation of sulphides and pyrite; $\mathrm{HCO}, \mathrm{Ca}, \mathrm{Mg}, \mathrm{Zn}, \mathrm{Ba}$, dolomite mineral dissolution and agrochemicals such as fertilizers and insecticides. Total Dissolved Solids (TDS), NH3, NO3- and turbidity had their input via wastewater. $\mathrm{PO}_{4}$ - was not found in water, being adsorbed on bottom sediments whose main retainer was goethite and kaolinite. The Spearman correlation revealed that high amounts of coliform bacteria $\left(9,4.10^{4}\right)$ correspond to larger amounts of Escherichia Coli found $\left(7,9.10^{4}\right)$ and Biochemical Oxygen Demand (7,00). The hierarchical clustering, interpreted along with the mineralogical analysis and the geoaccumulation index allowed one to distinguish the influences caused by mineral deposits in the accumulation of metals in the studied sediments. It obtained a "strong to extremely enriched" accumulation: $\mathrm{MgO}, \mathrm{Mn}$, $\mathrm{Co}$ and $\mathrm{Ba}$ evidencing the dissolution of carbonate rocks by the increase of $\mathrm{MgO}$ and decrease of $\mathrm{CaO}, \mathrm{Na}_{2} \mathrm{O}, \mathrm{K}_{2} \mathrm{O}$. In the "moderate accumulation" level there are $\mathrm{SiO}_{2}, \mathrm{Fe}_{2} \mathrm{O}_{3}, \mathrm{Cu}, \mathrm{Ni}, \mathrm{Zn}, \mathrm{Sr}$, and $\mathrm{Cr}$. The accumulation of $\mathrm{SiO}_{2}$ and $\mathrm{Fe}_{2} \mathrm{O}_{3}$ demonstrated an origin associated with $\mathrm{Fe}$ and $\mathrm{Al}$ silicates, such as clay minerals. These results enabled the creation of the geochemical model that help in the identification of sources and distribution of elements and metals present in the water and bottom sediments of the studied area. 


\section{SUMÁRIO}

\section{CAPÍTULO 1- INTRODUÇÃO}

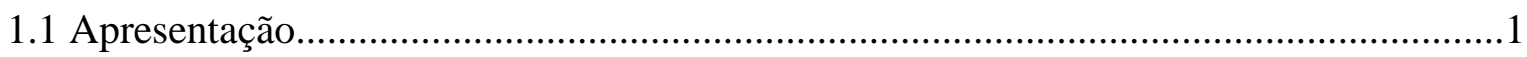

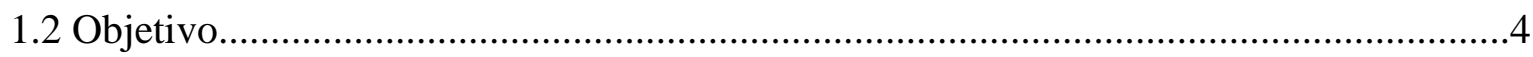

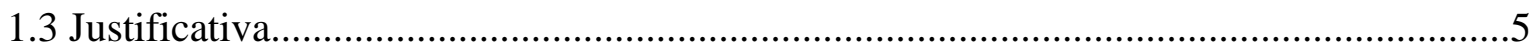

\section{CAPÍTULO 2- REVISÃO BIBLIOGRÁFICA}

2.1 Intemperismo e Processos Erosivos .6

2.2 Parâmetros: Temperatura, pH, Alcalinidade, Condutividade Elétrica (CE), Total de

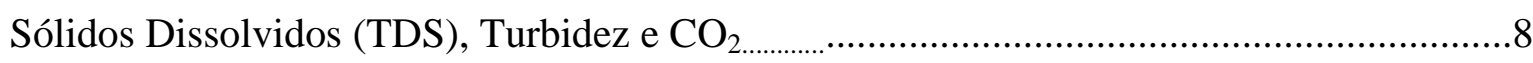

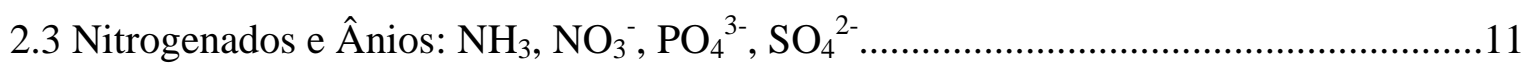

2.4 Oxigênio Dissolvido (OD), Demanda Bioquímica de Oxigênio (DBO) e Indicadores

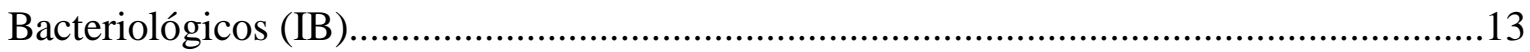

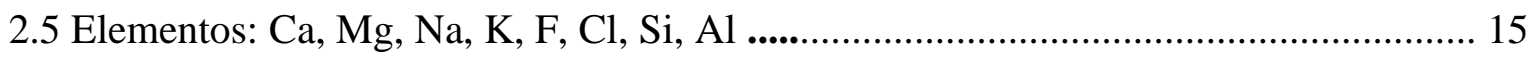

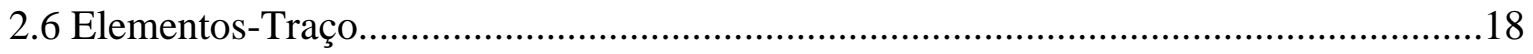

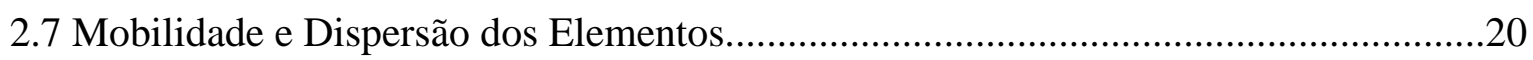

2.8 Métodos Geoquímicos na Avaliação dos Recursos Hídricos...........................................21

2.9 Métodos Analíticos para Determinação de Metais em Água e Sedimentos.....................22

2.10 Análise Mineralógica por Difração de Raio-X para Estudo do Sedimento de Fundo. .23

2.11 IQA e Uso dos Métodos: Geoquímicos, $\mathrm{I}_{\mathrm{geo}}$ e Estatísticos na Avaliação da Qualidade

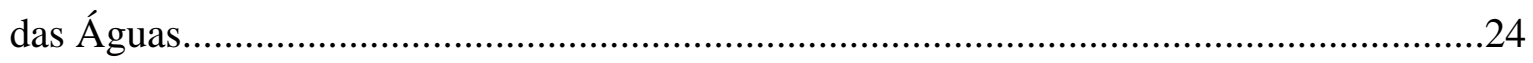

2.12 Trabalhos Relacionados ao uso das Técnicas Geoquímicas e Estatísticas....................26

\section{CAPÍTULO 3- ASPECTOS FISIOGRÁFICOS}

3.1 Localização da Área de Estudo - Rio das Antas, Anápolis-GO.....................................29

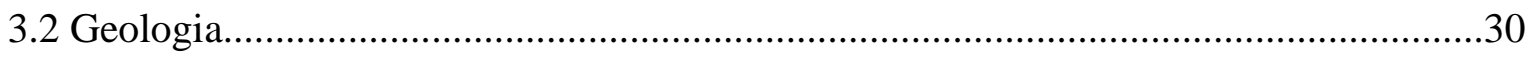

3.2.1 Complexo Granulítico Anápolis-Itauçu...............................................................32

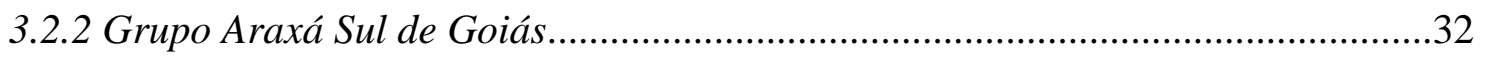

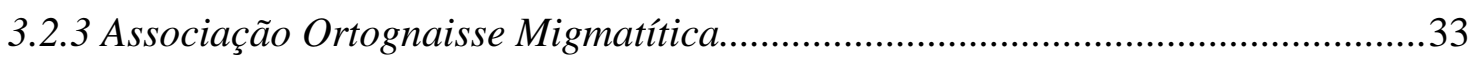

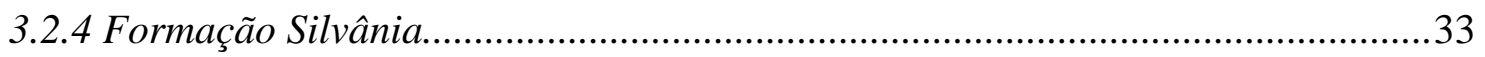




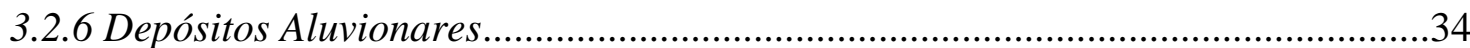

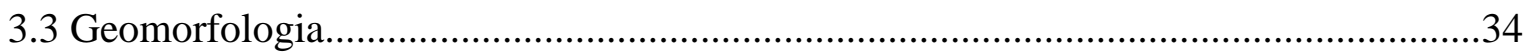

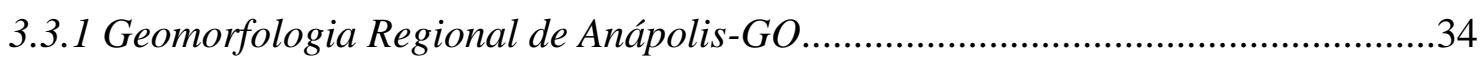

3.3.2 Geomorfologia Local: Rio das Antas, Perímetro Urbano de Anápolis-GO...........36

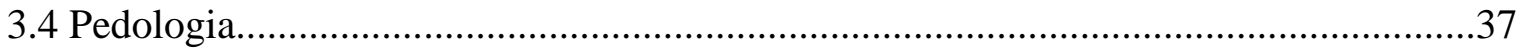

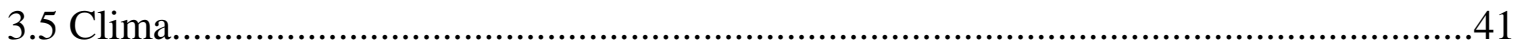

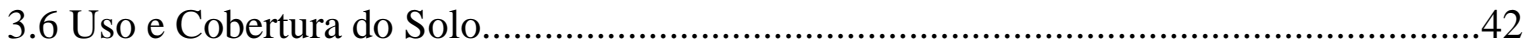

\section{CAPÍTULO 4- METODOLOGIA}

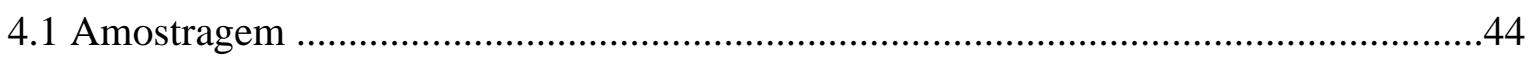

4.2 Análise das Amostras de Água e Sedimentos de Fundo................................................46

4.2.1 Determinação dos parâmetros físico-químicos.........................................................46

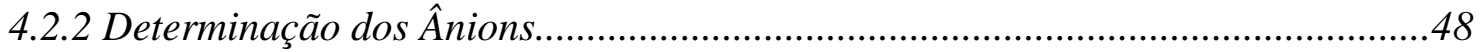

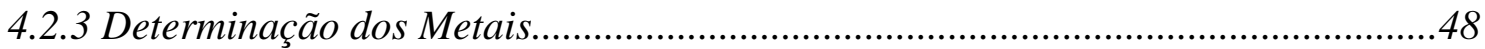

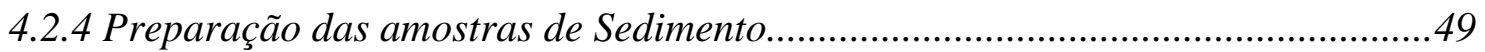

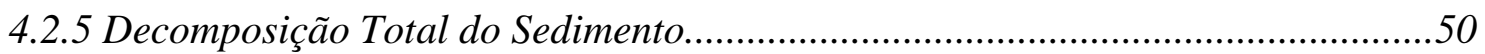

4.2.6 Matéria Orgânica e Sólidos Voláteis....................................................................51

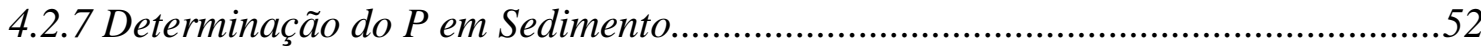

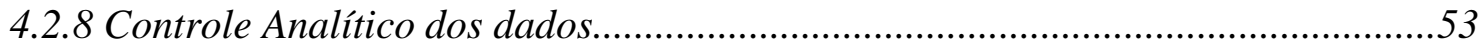

4.2.9 Análise Mineralógica por Difração de Raio-X.......................................................55

4.3 Procedimentos Microbiológicos Analíticos em Água Bruta...........................................56

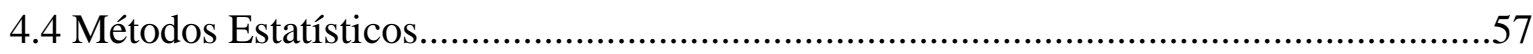

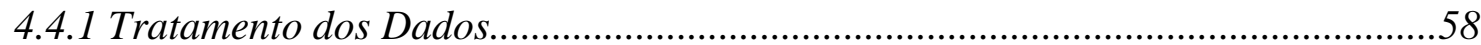

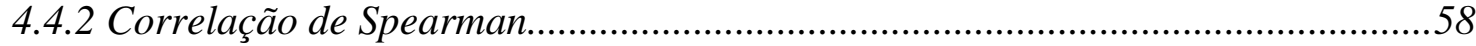

4.4.3 Análise de agrupamento (Cluster Analysis) Hierárquico......................................59

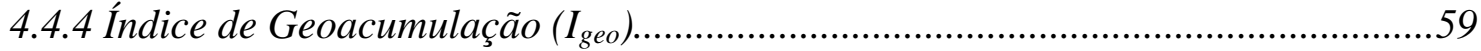

\section{CAPÍTULO 5- RESULTADOS E DISCUSSÃO}

5.1 Determinação dos Parâmetros Físico-Químicos e Microbiológico da água. 
5.1.1 Parâmetros Físicos da Água: Temperatura e Turbidez

5.1.2 TDS e Parâmetros Químicos da Água: $\mathrm{CE}, \mathrm{Ca}, \mathrm{Mg}, \mathrm{Na}$ e $\mathrm{K}, \mathrm{Cl}^{-}, \mathrm{NH}_{3}, \mathrm{NO}_{3}{ }^{-} \mathrm{PO}_{4}{ }^{3-}$

5.1.3 Parâmetros Químicos da Água: $\mathrm{SO}_{4}{ }^{2-}$ .63

$5.1 .4 \mathrm{pH}, \mathrm{HCO}_{3}^{-}, \mathrm{Fe}$ e $\mathrm{Al}$. 68

5.1.5 Indicadores Bacteriológicos e correlação com Parâmetros Físico-Químicos da Água .71

5.1.6 Oxigênio Dissolvido (OD) e Demanda Bioquímica de Oxigênio (DBO) . .73

5.1.7 Análise de Sedimentos Matéria Orgânica e Sólidos Voláteis (SV). . .74

5.2 Valor de Referência e Índice de Geoacumulação. .75

5.3 Correlação de Spearman - Parâmetros Físico-Químicos da Água e Sedimentos de Fundo. .79

5.4 Análise de Agrupamento Hierárquico (Cluster Analysis). .83

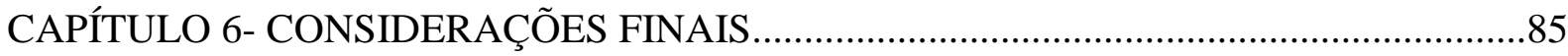

CAPÍTULO 7- REFERÊNCIAS BIBLIOGRÁFICAS........................................................87

ANEXOS 101

Anexo 1- Resultados dos parâmetros físico-químicos nas amostras de água do período seco.

Anexo 2- Resultados dos parâmetros físico-químicos nas amostras de água do período chuvoso 103

Anexo 3- Resultados da Análise de Sedimento de Fundo dos Elementos-Traço. 104 Anexo 4-I geo $_{\text {Calculado para Óxidos }}$ 105

Anexo 5 - Igeo Calculado para Elementos-Traço 106

Anexo 6 - Difratogramas obtidos nas análises mineralógicas. 107 


\section{LISTA DE FIGURAS}

Figura 1- Localização da Área de Estudo

Figura 2- Mapa Geológico da área do Rio das Antas (SIEG, 2013). .31

Figura 3- Mapa Geomorfológico da Área de Estudo (SIEG, 2013) .35

Figura 4- Mapa de Solo da Área de Estudo (SIEG, 2013) .38

Figura 5- Mapa de Cobertura do Solo (SIEG, 2013)...

Figura 6- Localização dos pontos de coleta de Água e Sedimentos de Fundo (SIEG,2013 Modificado).

Figura 7- Procedimento de abertura ácida de amostras de sedimento (Ataque III). .50

Figura 8- Procedimento de fusão de amostras de sedimento (Ataque II). .51

Figura 9- Fluxograma da enumeração de Coliformes Totais e Escherichia Coli em água bruta - Técnica dos Tubos Múltiplos (NMP) com substrato enzimático .57

Figura 10- Gráfico de temperatura $\left({ }^{\circ} \mathrm{C}\right)$ das águas do Rio das Antas nas estações seca e chuvosa.

Figura 11 - Turbidez (FTU) das águas do Rio das Antas nas estações seca e chuvosa .62

Figura 12- Panorama do Rio das Antas na região central do município de Anápolis/GO. Construção de novos canais de drenagem e do viaduto. .63

Figura 13- (A) Valores de $C E(\mu S / \mathrm{cm})$ e (B) TDS $\left(\mathrm{mg} \mathrm{L}^{-1}\right)$ das águas do Rio das Antas nas estações seca e chuvosa.. .64 
Figura 14- Matriz Scatterplots entre os parâmetros CE e os elementos $\mathrm{Ca}, \mathrm{Mg}$, Na e $\mathrm{K}$ no período da Seca.

Figura 15- Concentração de $\mathrm{P}_{2} \mathrm{O}_{5}$ em Sedimentos.....

Figura 16- Difratograma de sedimentos de fundo contendo os minerais predominantes da área (Amostra P4) .68

Figura 17- Concentração de $\mathrm{SO}_{4}{ }^{2-}$ em Águas.... .68

Figura 18- Comparação entre as concentrações de Concentrações de $\mathrm{Ca}, \mathrm{Mg}$ e $\mathrm{SO}_{4}{ }^{2-}$ $\left(m g L^{-1}\right)$, demonstrando a ocorrência de sedimentação nos pontos P19 e P20.

Figura 19- Concentração de pH no Rio das Antas durante a estação seca e chuvosa . .70

Figura 20- Concentração de $\mathrm{HCO}_{3}{ }^{-}$e pH no Rio das Antas durante a seca e chuvosa .70

Figura 21- Concentração de $\mathrm{Fe}_{2} \mathrm{O}_{3}$ e $\mathrm{Al}_{2} \mathrm{O}_{3}(\%)$ no sedimento de fundo do Rio das Antas....71

Figura 22- Coeficiente da Correlação de Spearman $(-1<r<1)$ e significância estatística dos parâmetros físico-químicos no Rio das Antas com valores de Coliformes Totais e E. Coli (significativo para $p<0,05)$ na terceira campanha de coleta (10 Pontos). 72

Figura 23- Concentração de OD e DBO no Rio das Antas - GO. . .74

Figura 24- Dendograma de Cluster das análises de água no período seco e chuvoso e dos sedimentos de fundo do Rio das Antas..... .83 


\section{LISTA DE TABELAS}

Tabela 1- Município de Anápolis: Evolução da População no período de 1991- 2010

Tabela 2- Granulometria em \% no Alto Curso do Rio das Antas.

Tabela 3- Pontos de Coleta de Água e Sedimento de Fundo. 44

Tabela 4- Comprimento de onda dos elementos utilizado no ICP/OES. .49

Tabela 5- Resultados obtidos para o padrão ION-915 53

Tabela 6- Resultados obtidos para o padrão PERADE. .53

Tabela 7- Resultados obtidos para o padrão SAN JOAQUIN SOIL 54

Tabela 8- Controle de qualidade do padrão C - basalto .54

Tabela 9- Resultados estatísticos relevantes e figuras de mérito obtidas pela análise de 5 curvas de calibração independentes lidas em 3 dias diferentes. .55

Tabela 10- Classificação do Índice de geoacumulação e descrição da qualidade do sedimento.

Tabela 11 Parâmetros Químicos da água na estação seca e chuvosa 66

Tabela 12- Descrição da Concentração dos parâmetros microbiológicos e físico-químicos...72

Tabela 13- Classificação da Correlação Spearman entre Parâmetros Microbiológicos e Físico-Químicos do Rio das Antas - GO. 
Tabela 14- Resultados obtidos para Óxidos e Sólidos Voláteis (PC) nos Sedimentos de Fundo.

Tabela 15- Valores de background - Anápolis - GO

Tabela 16- Classificação das amostras de acordo com o índice de geoacumulação

Tabela 17- Referência Geoquímica para as concentrações de sedimentos de fundo no Rio das Antas Anápolis - GO

Tabela 18- Correlação de Spearman na época seca. Os valores em vermelho apresentam correlação na época de seca e chuvosa. Os valores em negrito apresentam correlação apenas na seca. $\mathrm{R} \geq 50 \%$ 80

Tabela 19- Correlação de Spearman na época chuvosa. Os valores em vermelho apresentam correlação na época de seca e chuvosa. Os valores em negrito apresentam correlação apenas na época chuvosa. $\mathrm{R} \geq 50 \%$ . .81

Tabela 20- Correlação de Spearman sedimentos de fundo. Os valores em azul apresentam correlação em que $\mathrm{R} \geq 50 \%$ 


\section{LISTA DE SIGLAS}

ANA- Agência Nacional das Águas

APA- Área de Proteção Ambiental

APHA- American Public Health Association

AWWA- American Water Works Association

CE- Condutividade Elétrica

CETESB- Companhia Estadual de Tecnologia e Saneamento Básico

DBO- Demanda Bioquímica de Oxigênio

DRX- Difratometria de Raios-X

Eh- Potencial Redox

EAA- Espectrofometria de Absorção Atômica

EMBRAPA- Empresa Brasileira de Pesquisa Agropecuária

ETA- Estação de Tratamento de Água

HCA- Análise de Agrupamento Hierárquico

IB- Indicadores Bacteriológicos

IBGE- Instituto Brasileiro de Pesquisa e Estatística

IC- Cromatógrafo Iônico

ICP/OES - inductively coupled plasma optical emission spectrometry (espectrometria de emissão óptica por plasma acoplado indutivamente)

$\mathrm{I}_{\mathrm{geo}}$ - Índice de Geoacumulação

IPTG- isopropil- $\beta$-D-1-tio-galactopiranosídio

IQA- Índice de Qualidade de Ambiental

LAGEO- Laboratório de Geoquímica

LD- Limite de Detecção

LQ- Limite de Quantificação

MPI- Índice de Poluição Metálica

MS- Material em Suspensão

MUG- metilumbeliferil- $\beta$-D-glicoronideo

NIST- National Institute of Standards and Technology

NMP- Número Mais Provável

NWRI- National Water Research Institute 
OD- Oxigênio Dissolvido

ODI- Oxigênio Dissolvido Inicial

ODF- Oxigênio Dissolvido Final

pH - Potencial Hidrogeniônico

PLGB- Programa de Levantamentos Geológicos Básicos do Brasil

SANEAGO- Saneamento de Goiás

SIEG- Sistema de Informação Geográfica do Estado de Goiás

SQG $_{\mathrm{S}-}$ Normas de Qualidade de Sedimentos

TDS- Total de Sólidos Dissolvidos

WPCF- Water Pollution Control Federation 


\section{CAPÍTULO 1}

INTRODUÇÃO

A água, essencial à manutenção da vida, encontra-se presente em quase todas as atividades humanas. Ela é utilizada para diferentes fins como abastecimento público, dessedentação de animais, irrigação, recreação, pesca, indústria e transporte. O uso constante da água de maneira não planejada e irracional altera sua composição química e qualidade em relação a seu destino (GUEDES, 2012a). A considerável descarga de poluentes no meio aquático pela indiscriminada entrada de sólidos em suspensão, metais dissolvidos, nutrientes, organismos patogênicos e outros, são os principais contribuintes na poluição dos mananciais. Essas concentrações em grande escala, acabam comprometendo a capacidade de transporte e dissolução dos rios causando impactos negativos em muitas biotas. de Oliveira e Marins (2011) afirmam que a introdução de substâncias alheias ao ambiente, "tanto pela exploração dos recursos naturais quanto pela descarga de resíduos [...], começou a superar, em muitas regiões, a resiliência do ambiente", se tornando uma preocupação à preservação da vida.

Segundo Rohde (2004) o impacto ambiental ocasiona uma "mudança sensível, positiva ou negativa, nas condições de saúde e bem estar das pessoas e na estabilidade do ecossistema". Vale lembrar que nem toda alteração ambiental é produzidas pelas atividades humanas, podendo ser também de origem natural. Compreende-se por causas naturais a interação contínua e constante entre litosfera, biosfera e atmosfera, definindo um equilíbrio dinâmico para o ciclo da água (REBOUÇAS; BRAGA, 2002). Os vários processos controladores da qualidade da água de determinado manancial fazem parte de um frágil equilíbrio natural, motivo pelo qual alterações de ordem física, química, climática ou antrópica, podem modificar a sua composição (DONADIO; GALBIATTI; de PAULA, 2005).

O desequilíbrio de um ecossistema está associado a toda e qualquer alteração que modifique o balanceamento natural do ambiente. Valores elevados de elementos químicos ou compostos orgânicos, necessariamente não indicam instabilidade do meio aquático, mas podem ser provenientes de componentes geológicos. Partindo do pressuposto que as atividades humanas aceleram e modificam o ambiente, nas paisagens alteradas pela presença de indústrias, população e agricultura "pode-se inferir, caso se encontre excesso de elementos 
químicos em água, em sedimentos de fundo e/ou em suspensão, que sua presença denota interferência antrópica no ambiente" (GUEDES, 2012a).

Dentre as ações humanas de maior influência sobre os recursos hídricos estão a expansão e intensificação das atividades econômicas e o adensamento populacional desordenado. As principais alterações nos ecossistemas originários do desenvolvimento das cidades sobre o ciclo hidrológico estão ligadas ao aumento das superfícies impermeáveis próximas a zonas de expansão ou inseridas no perímetro urbano. As impermeabilizações aumentam o runoff, influenciam na taxa de erosão e na entrada de poluentes derivados de lixos, vazamentos, resíduos industriais e veiculares (TUCCI, 1997). Aliado à extração da cobertura vegetal, o escoamento superficial favorece a desagregação inicial das partículas das rochas e, portanto, sua concentração em sedimentos na enxurrada provocando o assoreamento dos rios (VANZELA; HERNANDEZ; FRANCO, 2010).

Ferreira e Matos (2012) atribuem às águas pluviais nas cidades, o transporte de diversas substâncias acumuladas em tempo seco para os sistemas lóticos, resultantes, sobretudo de ações urbanas e do tráfego. Estas substâncias podem ser "partículas poluentes dissolvidas, coloidais e sólidas, numa mistura heterogênea que inclui compostos orgânicos e inorgânicos, nutrientes, óleos, gorduras e metais pesados" (FERREIRA; MATOS, 2012). Na pesquisa realizada em Lisboa, Ferreira e Matos (2012) encontraram referências bem acima das que são consideradas pela legislação portuguesa para qualidade de águas pluviais. Segundo os autores apenas $40 \%, 60 \%$ e $15 \%$ perfaziam valores limite de emissão para parâmetros como, carência bioquímica em oxigênio, carência química em oxigênio e sólido suspenso total, respectivamente. Os resultados de coliformes totais e fecais excediam em todas as amostras os padrões limítrofes definidos para a classe de água pluvial.

O lançamento de esgotos e efluentes aliados a baixa infraestrutura de muitas cidades tem contribuído para tornar o acesso à água de boa qualidade mais difícil, refletindo de maneira negativa na saúde da população. Estudos realizados na Romênia constataram que $43 \%$ da população não possuem fontes de água potável e apresentam a pior infraestrutura neste campo, com a pontuação, de 5,6 em uma escala de 1 a 10, sendo que a média é de 9,8 na União Européia (CÃLIN; ROŞU, 2011). Segundo Popovici, Verart e Van de Kerk (2008), nos anos de 1985 e 1996, a Romênia foi acometida de 2.913 casos de Baby Blue Desease, dos quais 102, fatais. Tudor (2007) relatou ainda o fato de 128 casos infantis ocorridos em Alba 
de methemoglobine aguda, dentre elas, três fatais, procedentes da água consumida pela população.

$\mathrm{O}$ acúmulo de $\mathrm{N}$ e $\mathrm{P}$, fator predominantemente urbano (esgoto doméstico) e agrícola (superfosfatos) modificador da qualidade da água, adicionam produtos como fezes, urina, restos de comida e elementos químicos advindos da limpeza em processos industriais. Os sabões e detergentes não biodegradáveis contribuem para elevar o teor das concentrações de fosfatos na água induzindo ao conhecido tipo de poluição denominado eutrofização (RYDING; RAST, 1989), fenômeno natural quando há envelhecimento do sistema aquático, ou acelerado, se persistir o lançamento de efluentes domésticos, escoamento superficial urbano e de áreas agrícolas. A eutrofização tem como consequência, significativa redução da concentração de $\mathrm{O}_{2}$ e mudança das características da água como turbidez, cor, pH e condutividade elétrica. Aumenta-se também a quantidade de $\mathrm{NH}_{3}$ que causa liberação de $\mathrm{CH}_{4}$ e $\mathrm{H}_{2} \mathrm{~S}$, substância que provoca odor e toxidez na água eliminando diversos organismos aquáticos.

Segundo Andreoli e Carneiro (2005) o P é considerado o maior responsável pela eutrofização artificial e concentrações superiores a $0,03 \mathrm{mg} \mathrm{L}^{-1}$ em águas superficiais. As substâncias introduzidas no meio aquático diminuem a entrada da luz solar, aumentam a decomposição da matéria orgânica e favorecem o crescimento excessivo de algas. De acordo com Rocha e Branco (1985) a razão entre N e P nos esgotos domésticos de apenas 8:1, 6:1 ou 4,5:1, já permitem condições suficientes para florações de algas. Em outras palavras, é necessário entre 15 a 30 partes de $\mathrm{N}$ para 1 de $\mathrm{P}$, relação geralmente não encontrada nas águas naturais consideradas em bom estado de conservação. Branco (1986), estudando os lagos de Wisconsin (EUA) verificou que o fenômeno da floração de algas se dava sempre que a concentração de $\mathrm{N}$ se elevava a $0,30 \mathrm{mg} \mathrm{L}^{-1}$ e a de $\mathrm{P}$ a $0,01 \mathrm{mg} \mathrm{L}^{-1}$, prevalecendo a razão de $30: 1$.

A agricultura, atividade potencialmente impactante, não só pelo fato de consumir muita água, mas também por contribuir com um volume cumulativo de inseticida, pesticida e fertilizante, liberam aos ecossistemas aquáticos metais como $\mathrm{Zn}, \mathrm{Cu}$ e outros. Gimeno-Garcia (1996) verificou esse fato em uma pesquisa onde se utilizava pesticidas e fertilizantes no cultivo de arroz. Os resultados detectaram elevadas concentrações de $\mathrm{Cu}, \mathrm{Zn}, \mathrm{Co}$ e $\mathrm{Cd}$ em superfosfatos e Zn, Mn, Fe e Ni em pesticidas. Os solos avaliados continham altos teores de metais apresentando-se tóxicos. Bortoluzzi et al. (2006) asseguraram que, apesar da existência 
de alguns processos atuantes na imobilização das moléculas de agrotóxicos e da adsorção das mesmas e elementos traço por cargas constituintes do solo, cerca de $20 \%$ acabam por atingir as águas superficiais. Um estudo na lavoura de fumo por estes autores ratificou o comprometimento da qualidade das águas superficiais em Agudo-RS, atestando a presença de princípios ativos dos agrotóxicos imidacloprid, atrazina e clomazone.

Diversos estudiosos têm buscado compreender a interação existente entre os ecossistemas e mencionam que a composição química da água está fortemente relacionada ao meio litológico a qual circula. "Ao associar-se a geologia, geomorfologia, hidrogeologia, recursos minerais têm-se o escopo que pode explicar a hidrogeoquímica dos recursos hídricos, no tocante à sua qualidade ambiental" (GUEDES, 2012a). Diante do que foi apresentado fica evidente que os problemas ambientais precisam ser analisados cautelosamente para se evitar complicações irreversíveis. Nesse sentido, a geoquímica vem auxiliar e contribuir na ampliação do conhecimento a respeito do tema. Sua capacidade de relacionar a distribuição e o comportamento dos elementos químicos possibilita identificar as alterações de origem natural e antrópica, além dos diversos processos que ocorrem em uma bacia de drenagem, sendo considerada uma poderosa ferramenta para estudos nesse âmbito.

\subsection{Objetivo}

\subsubsection{Geral}

Avaliar a qualidade da água e sedimentos de fundo do Rio das Antas - GO desenvolvendo modelo geoquímico que possa ser aplicado em sistemas aquáticos da região. Este modelo servirá de auxílio para definir quais as fontes da geologia local e antrópica que contribuem ou interferem na composição físico-química da água.

\subsubsection{Específicos}

- Identificar as fontes dos compostos físico-químicos e metais na água e sedimentos de fundo.

- Identificar níveis de alteração da água a partir de índices hidrogeoquímicos.

- Realizar análises bacteriológicas verificando a qualidade da água quanto à presença/ausência e quantificação de microorganismos patogênicos por meio de indicadores de Coliformes Totais e Escherichia Coli. 
- Propor modelo de avaliação ambiental aplicado ao estudo da qualidade da água em regiões que sofrem interferências urbanas semelhantes à área de estudo.

\subsection{Justificativa}

Das cinco microbacias hidrográficas que fazem parte da macrorregião de AnápolisGO, a Microbacia do Rio das Antas é uma das que apresenta situação bastante frágil por percorrer não só áreas rurais, mas também grande parte do centro urbano. Dentre as cidades que formam o Estado de Goiás, o município de Anápolis localiza-se em uma Área de Proteção Ambiental (APA): a APA do Rio João Leite criado pelo Decreto No 5.704/2002. O processo histórico de ocupação da cidade mostrou que os usos de solo permitidos no assentamento do vale do Rio das Antas e seus tributários, foram os mais diversos possíveis, não constando nenhum plano relacionado à preservação dos recursos naturais, sobretudo córregos, nascentes e matas (CORRÊA, 2005).

Das transformações ocorridas no meio urbano em Anápolis, a mais visível é o aumento do número e intensidade das inundações provocadas pelo transbordamento do rio devido a impermeabilização e canalização de sua planície. Em períodos chuvosos as águas chegam a invadir casas localizadas nas margens, sendo a qualidade dessas águas questionáveis. A preocupação em relação à qualidade da água do Rio das Antas se justifica pela deposição de esgotos domésticos, industriais e rejeitos de drenagens urbanas nas águas fluviais, fatores que podem agregar possíveis passivos que direta ou indiretamente são capazes de comprometer a saúde da população local.

Poucos estudos têm sido efetivamente realizados no que tange à qualidade das águas do sistema lótico em questão, Corrêa (2005), Ferreira (2009), Júnior et al. (2010) e Oliveira, Barcello e Peixoto (2013). Estes estudos realizados no Rio das Antas tiveram como base apenas análises isoladas de amostras de água ou macroscópicas, nenhum deles associou a interação da ocupação urbana com aspectos da composição da água e sedimentos de fundo propostos pela geoquímica ambiental, ferramenta dessa pesquisa. Assim, ao término deste trabalho espera-se obter dados importantes sobre a real situação do Rio das Antas em suas peculiaridades e um conhecimento empírico da área na avaliação da qualidade ambiental. 


\section{CAPÍTULO 2}

REVISÃO BIBLIOGRÁFICA

\subsection{Intemperismo e Processos Erosivos}

As paisagens formadoras da crosta terrestre refletem os mecanismos que associam os processos de sua composição geológica e geomorfológica. Certos tipos de sedimentos são restritos a específicas localidades (MIRLEAN; TELLES; DUARTE, 2006). Define-se como intemperismo todo processo onde as estruturas minerais complexas por meio da ação de agentes físicos, químicos e biológicos resultam na desagregação de partículas tornando se estruturas mais simples (FORMOSO, 2006). Os processos físicos (fragmentação sem a modificação química e mineralógica da rocha matriz) favorecem as reações químicas provenientes de agentes como a água, o oxigênio livre e o dióxido de carbono. Tais processos ocorrem com maior intensidade em regiões tropicais influenciadas pela ação do clima modificando as estruturas geológicas naturais.

$\mathrm{O}$ agente mais significante do intemperismo é a água. Ela é um solvente muito ativo capaz de reagir com o meio percolado incorporando substâncias orgânicas e inorgânicas. É considerada de fundamental importância nas mudanças de estrutura do solo, desintegração dos minerais das rochas e liberação de íons (MARTINS et al., 2011). Seu efeito mais intenso se dá à medida que se acidifica devido à dissolução de $\mathrm{CO}_{2}$ da atmosfera ou à presença de ácidos húmicos. As principais reações da água são: hidratação, dissolução, oxidação e hidrólise.

A hidratação refere à associação de moléculas de água ou de grupos $\mathrm{OH}$ com os minerais. Essa reação promove a "quebra" do retículo cristalino da substância e forças existentes entre cátions e ânions no sólido são substituídos por forças entre água e íons.

$$
\mathrm{CaSO}_{4}+2 \mathrm{H}_{2} \mathrm{O}===>\mathrm{CaSO}_{4} \cdot \mathrm{H}_{2} \mathrm{O}
$$

(anidrita) (gipso)

A dissolução é a solubilização direta de alguns minerais por ácido para substâncias polares ou iônicas transformando-as em soluções aquosas. Sais simples como $\mathrm{NaCl}$, dissolvem-se facilmente dando origem a soluções iônicas, podendo ser rapidamente 
transportados e precipitados em outros locais. Esse tipo de dissolução é chamado dissolução por dissociação, típica dos sais (SPOSITO, 2008). A interação entre as moléculas do solvente (água) e as do soluto é que são responsáveis pelo processo de solubilização. Os carbonatos são minerais muito susceptíveis a este tipo de reação. Se houver $\mathrm{CO}_{2}$ dissolvido na água, ocorre a seguinte reação:

$$
\mathrm{CaCO}_{3}+\mathrm{H}^{+}+\mathrm{HCO}_{3}^{-}===>\mathrm{Ca}\left(\mathrm{HCO}_{3}\right)_{2}
$$

(calcita) (bicarbonato de cálcio)

Segundo Fiorucci e Benedetti Filho (2005) o agente oxidante mais importante em águas naturais é o $\mathrm{O}_{2}$. Devido à oxidação, os minerais formados em ambientes deficitários em $\mathrm{O}_{2}$ são convertidos em compostos de valência mais elevados. Essa reação afeta rochas cujos minerais contém $\mathrm{Fe}^{2+}$ que se oxida $\mathrm{em} \mathrm{Fe}^{3+}$ e é acompanhada por uma variação de cor avermelhada ou amarelada nas superfícies afetadas (EMSLEY, 1998).

$$
\begin{aligned}
& \mathrm{Fe}_{2} \mathrm{SiO}_{4}+1 / 2 \mathrm{O}_{2}+2 \mathrm{H}_{2} \mathrm{O}<== \\
& \begin{array}{l}
\text { (olivina) } \\
\text { (hematita) }
\end{array} \mathrm{Fe}_{2} \mathrm{O}_{3}+\mathrm{H}_{4} \mathrm{SiO}_{4}
\end{aligned}
$$

A hidrólise promove a interação entre os íons $\mathrm{H}^{+}$e $\mathrm{OH}^{-}$da água com os íons do mineral que rompe as ligações entre o $\mathrm{O}_{2}$ e o $\mathrm{Si}$ ou entre o $\mathrm{O}_{2}$ e os metais, ou ainda entre o $\mathrm{O}_{2}$ e o C.

$$
\begin{aligned}
& \mathrm{KAl}_{2} \mathrm{Si}_{3} \mathrm{O}_{8}+\mathrm{H}^{+}+\mathrm{OH}===>\mathrm{H}^{-}\left(\mathrm{AlSi}_{3} \mathrm{O}_{8}\right)+\mathrm{K}^{+}+\mathrm{OH}^{-} \\
& \text {(feldspato-K) }
\end{aligned}
$$

$\mathrm{Na}$ superfície do mineral, os ions $\mathrm{H}^{+}$substituem os ions $\mathrm{K}^{+}$fazendo o mineral ficar instável. Continuando sua decomposição hidrolítica tem-se:

$$
\begin{gathered}
2 \mathrm{H}\left(\mathrm{AlSi}_{3} \mathrm{O}_{8}\right)+5 \mathrm{H}^{+}+5 \mathrm{OH}^{-}===> \\
2 \mathrm{Al}_{2} \mathrm{Si}_{2} \mathrm{O}_{5}(\mathrm{OH})_{4}+4 \mathrm{H}_{2} \mathrm{SiO}_{3} \\
(\text { caulinita }) \\
2 \mathrm{Al}_{2} \mathrm{Si}_{2} \mathrm{O}_{5}(\mathrm{OH})_{4}+5 \mathrm{H}^{+}+5 \mathrm{OH}===>2 \mathrm{Al}(\mathrm{OH})_{3}+2 \mathrm{H}_{4} \mathrm{SiO}_{4} \\
\text { (caulinita) } \\
\text { (gibbsita) }
\end{gathered}
$$


Considerando que essas reações incidem em diferentes tipos de rochas ao originar solos com composição mineralógica distintas, o resultado é uma variedade de minerais portadores de metais-traço presente em rochas ígneas, metamórficas e sedimentares. Dentre os três tipos de rochas, as ígneas são as que mais favorecem os estudos de proveniência e balanço de perdas e ganhos dos elementos químicos, por se destacarem quanto ao ponto de partida na ciclagem dos elementos em ambientes naturais (PHILLIPS et al., 1998).

\subsection{Parâmetros: Temperatura, pH, Alcalinidade, Condutividade Elétrica (CE), Total de Sólidos Dissolvidos (TDS), Turbidez e $\mathrm{CO}_{2}$}

A temperatura caracteriza grande parte dos outros parâmetros físicos da água tais como a densidade, viscosidade, pressão de vapor e solubilidade dos gases dissolvidos (TUCCI, 2004). O fato de a água atingir a densidade máxima a temperatura de $4{ }^{\circ} \mathrm{C}$, proporciona-lhe uma capacidade de ocupar as camadas mais profundas de rios e lagos. Essa característica faz com que no inverno os lagos em países frios congele apenas a superfície favorecendo a sobrevivência de muitos peixes e outras espécies aquáticas. Em ambientes tropicais, a temperatura é mais elevada e a tendência dos organismos pequenos e das partículas em suspensão é ir para o fundo devido a viscosidade da água ser menor, por viscosidade, entendese a resistência do líquido ao escoamento.

A concentração dos gases na água depende da chamada pressão parcial do gás e da temperatura, ou seja, se um gás a uma temperatura de $20^{\circ} \mathrm{C}$ apresentar solubilidade química absoluta de $43 \mathrm{mg} \mathrm{L}^{-1}$ de oxigênio, esse valor, ao ser multiplicado pela pressão parcial do gás resulta na quantidade máxima que o mesmo pode atingir no meio (BRASIL, 2006). Assim, em sistemas aquáticos tropicais há pouca disponibilidade de $\mathrm{O}_{2}$ se comparados com os de clima temperado, ou o aumento deste em ambientes hídricos próximos ao nível do mar (maior pressão atmosférica) em relação a outros localizados nas montanhas.

A temperatura aliada ao $\mathrm{pH}$, também afeta a taxa das reações químicas/biológicas e a distribuição de substâncias dissolvidas em rios e lagos. A determinação do pH é um dos parâmetros mais importantes no contexto da química da água. Ele fornece a concentração de íons de hidrogênio $\mathrm{H}^{+}$de forma antilogarítmica numa faixa de 0 a 14 indicando condições de acidez (0 a 7), neutralidade (7) ou alcalinidade ( 7 a 14). De modo geral, quando a temperatura da água aumenta o pH diminui, salvo exceções semelhantes às encontradas por Neves, Horn e 
Fraga (2008) que depararam com uma variação sazonal cuja temperatura média oscilava em torno de $3^{\circ} \mathrm{C}$ e apresentava $\mathrm{pH}$ ácido. Segundo os autores, essa ocorrência predominou em locais de elevado teor com ácidos húmicos resultante da decomposição da matéria orgânica. Os critérios de proteção da vida aquática costumam fixar $\mathrm{pH}$ entre 6 e 9, muitos peixes e outros animais podem sobreviver a $\mathrm{pH}$ menor que 5, contudo, nesse valor, os metais se solubilizam facilmente, aumentando a possibilidade de toxidez (MACEDO, 2006). Brasil (2006) destaca exemplos de variação em pH abaixo do valor prefixado (6 a 9) para desenvolvimento de seres aquáticos fazendo referência aos que se desenvolvem em cursos d'água na bacia amazônica. Em decorrência da decomposição da vegetação na Amazônia, os rios da região têm cores intensas e o pH das águas é ácido variando de 4 a 6 .

Com a atividade fotossintética (absorção de ácido carbônico) ocorre elevação no valor do pH na superfície e diminuição do mesmo no fundo em função do predomínio de processos respiratórios (liberação de gás carbônico). Geralmente um $\mathrm{pH}$ muito ácido ou muito alcalino está associado à presença de despejos industriais. Ele reflete o tipo de solo por onde a água percola, uma vez que sua fonte natural emana da dissolução de rochas, adsorção de gases da atmosfera, oxidação da matéria orgânica e da fotossíntese. Quando a quantidade de H é abundante, os íons da água reagem para neutralizá-los como meio de resistir às mudanças do parâmetro $(\mathrm{pH})$, a esse artifício dá-se o nome de alcalinidade. Seus principais constituintes são $\mathrm{HCO}_{3}{ }^{-}, \mathrm{CO}_{3}{ }^{2-}$ e $\mathrm{OH}^{-}$. Nem sempre o processo de neutralização acontece de maneira homogenia, Silva, Galvíncio e Almeida (2010), encontraram núcleos de altos valores de $\mathrm{pH}$ onde a temperatura se elevava. Eles presenciaram o aumento das concentrações de $\mathrm{CO}_{3}{ }^{2-} \mathrm{e}$ $\mathrm{HCO}_{3}{ }^{-}$em regiões semi-áridas ou quando ocorriam altas insolações. Tal estudo abrangeu áreas no curso do Alto, médio e submédio do Rio São Francisco em 30 estações fluviométricas, coletadas de 1976 a 2008, através da Agência Nacional das Águas (ANA).

$\mathrm{A}$ alcalinidade está associada à dureza da água se correlacionada a $\mathrm{CO}_{3}{ }^{2-}$. "Águas de elevada dureza reduzem a formação de espuma, [...] além de provocar incrustações nas tubulações de água quente, caldeiras e aquecedores, em função da precipitação dos cátions em altas temperaturas" (BRASIL, 2006). Determina-se o grau de dureza do meio líquido através da quantidade de cátions multivalentes de $\mathrm{Ca}^{2+}$ e $\mathrm{Mg}^{2+}$ e em menor escala de $\mathrm{Fe}^{2+}, \mathrm{Mn}^{2+}, \mathrm{Sr}^{2+}$ e $\mathrm{Al}^{3+}$ associados aos ânions da solução aquosa (MORAIS, 2008). Em sistemas hídricos de dureza reduzida, a biota se torna mais sensível à presença de substâncias tóxicas, já que a toxicidade é inversamente proporcional ao grau de dureza da água. 
A CE é outro parâmetro variante em função da temperatura e influenciado pela quantidade de substâncias ionizadas dissolvidas (KEMERICH et al., 2013). Seus valores, expressos em micro Siemens $\left(\mu \mathrm{S} \mathrm{cm}^{-1}\right)$, manifesta a capacidade de conduzir a corrente elétrica em razão da dissociação em ânions e cátions das substâncias diluídas. Para Esteves (1998) e Silva, Galvíncio e Almeida (2010) a CE não determina especificamente quais íons estão presentes na água, mas pode alertar para o reconhecimento de prováveis impactos ambientais porque indica modificações na composição da água, especialmente na sua concentração mineral. Neves, Horn e Fraga (2008) comprovaram essa propriedade, ao observarem valores elevados de CE em pontos de despejo receptores de efluente doméstico. Sobre o assunto, Brasil (2006) afirma que, “enquanto as águas naturais apresentam teores de condutividade na faixa de 10 a $100 \mu \mathrm{S} \mathrm{cm}^{-1}$, em ambientes poluídos por esgotos domésticos ou industriais os valores podem chegar até $1.000 \mu \mathrm{S} \mathrm{cm}^{-1}$,.

Sampaio et al. (2007), mostraram que a CE apresenta relação proporcional à concentração de TDS em águas residuárias, no entanto, segundo Mestrinho (1999), as concentrações desses dois parâmetros dependem da mobilidade, valência dos ânions e da temperatura da água no momento da medição. O TDS engloba, além de materiais dissolvidos, os coloidais, voláteis, não voláteis, com ou sem conteúdo orgânico. Estudo desenvolvido por Martinelli et al. (1989) no rio Amazonas quantificou o transporte total de material dissolvido lançado no oceano, cerca de $2,7 \times 10^{8} \mathrm{t}^{-1}$, sendo considerado por este resultado, um rio de grande mobilidade de elementos. Segundo os autores, as áreas de drenagem da bacia amazônica rica em $\mathrm{Ca}$ e $\mathrm{SiO}_{2}$ são os fatores responsáveis pela elevada dissolução de silicatos encontrados.

A turbidez aliada à Cor expressa a dificuldade da água transmitir luz. As principais fontes provêm de partículas como silte, argila e materiais suspensos oriundos dos processos de intemperismo que ocorrem em rochas e solos ou das atividades do homem. Também a presença de matéria orgânica, plâncton e outros organismos microscópicos contribuem para o aumento da turbidez e pode causar problemas como o aumento de $\mathrm{CO}_{2}$ (SANTOS, 1997). $\mathrm{Na}$ decomposição do material orgânico ou na falta de luz, os vegetais deixam de converter $\mathrm{CO}_{2}$ em $\mathrm{O}_{2}$ e utilizam $\mathrm{O}_{2}$, liberando $\mathrm{CO}_{2}$. Se o índice de $\mathrm{CO}_{2}$ for muito alto poderá prejudicar a vida aquática, aconselha-se evitar índices acima de $30 \mathrm{mg} \mathrm{L}^{-1}$ (PÁDUA, 2010). O $\mathrm{CO}_{2}$ dissolvido na água está diretamente ligado ao $\mathrm{pH}$ e aos $\mathrm{CO}_{3}{ }^{2-}$, pois, as reações químicas entre eles juntamente com a contribuição do $\mathrm{H}_{2} \mathrm{SO}_{4}, \mathrm{HCl}$ e $\mathrm{HNO}_{3}$ geram $\mathrm{H}_{2} \mathrm{CO}_{3}$ reduzindo o $\mathrm{pH}$. 
Para que isso não ocorra, as águas naturais contêm quantidades variáveis de $\mathrm{CO}_{2}$ que estabelecem um equilíbrio com os $\mathrm{CO}_{3}{ }^{2-}$ existentes, principalmente o $\mathrm{Ca}$, ou seja, “[...] o teor de $\mathrm{CO}_{2}$ define uma proporção entre as quantidades de carbonatos e bicarbonatos, substâncias fundamentais ao sistema de "tamponamento" do meio aquático" (PÁDUA, 2010).

\subsection{Nitrogenados e Ânios: $\mathrm{NH}_{3}, \mathrm{NO}_{3}{ }^{-}, \mathrm{PO}_{4}{ }^{3-}, \mathrm{SO}_{4}{ }^{2-}$}

O N alterna-se entre várias formas e estados de oxidação. As mais importantes do ponto de vista ambiental se diferenciam no grau de oxidação do átomo, um é a $\mathrm{NH}_{3}$ e outro, $\mathrm{o}_{3}{ }^{-}$. $\mathrm{O} \mathrm{NO}_{2}{ }^{-}$, por estar em pequena quantidade, é bastante instável na presença de $\mathrm{O}_{2}$ ocorrendo no estado intermediário entre $\mathrm{NH}_{3}$ e $\mathrm{NO}_{3}^{-}$(nitrificação) ou entre $\mathrm{NO}_{3}{ }^{-}$e gás nitrogênio (denitrificação) (PEREIRA, 2004). $\mathrm{A} \mathrm{NH}_{3}$ é a forma mais reduzida de nitrogênio orgânico e inclui $\mathrm{NH}_{3}$ e $\mathrm{NH}_{4}{ }^{+}$dissolvidos. Embora seja somente um pequeno componente no ciclo total do $\mathrm{N}$, esta contribui para a fertilização da água, mas é tóxica para os peixes. Em concentrações acima de 0,2 $\mathrm{mg} \mathrm{L}^{-1}$ ou, conforme Bitton (1994), 4,6 mg de $\mathrm{O}_{2}$ para cada miligrama de $\mathrm{NH}_{4}{ }^{+}$, pode causar a morte de algumas espécies. $\mathrm{O}_{\mathrm{NH}_{4}}{ }^{+}$é considerado uma substância não persistente e não cumulativa.

$\mathrm{O} \mathrm{NO}_{3}{ }^{-}$existe em sais, soluções aquosas e no $\mathrm{HNO}_{3}$. É a forma mais oxidada do $\mathrm{N}$. Com exceção de algumas ocorrências como evaporíticos, o $\mathrm{N}$ e seus compostos não são encontrados nas rochas da crosta terrestre. Ele é continuamente reciclado pelas plantas e animais ao converter $\mathrm{NO}_{3}{ }^{-}$em $\mathrm{N}$ orgânico. A maioria das águas de superfície contém $\mathrm{NO}_{3}{ }^{-}$, contudo, valores acima de $5 \mathrm{mg} \mathrm{L}^{-1}$ podem indicar condições sanitárias inadequadas, pois os resíduos humanos e de animais são enriquecidas fontes que colaboram para aumentar sua concentração (OGERA, 1995). "Do ponto de vista sanitário, esse elemento, ao ser incorporado a qualquer água, aumenta a proliferação de microrganismos, podendo aumentar a DBO do sistema" (DONADIO; GALBIATTI; de PAULA, 2005). Os compostos de N na água são usualmente admitidos como indicação da presença de matéria orgânica e dependendo dos teores, interpretadas como sinal de poluição. Eles mostram o estágio da eventual alteração, se esta é recente, o $\mathrm{N}$ estará na forma de $\mathrm{N}$ orgânico ou $\mathrm{NH}_{3}$, e se antiga, basicamente na forma de $\mathrm{NO}_{3}{ }^{-}$. Em seres humanos, principalmente bebês, o consumo da água com elevadas quantidades de $\mathrm{NO}_{3}{ }^{-}$pode desenvolver a metaemoglobinaemia. O Sistema Digestório das crianças com menos de três meses de idade possuem bactérias que reduzem o $\mathrm{NO}_{3}{ }^{-} \mathrm{a} \mathrm{NO}_{2}{ }^{-}$, 
este se liga a moléculas de hemoglobina, impedindo-as de transportarem oxigênio para células do organismo. A deficiência em $\mathrm{O}_{2}$ leva a danos neurológicos permanentes, dificuldade de respiração e em casos mais sérios, à morte por asfixia. Pesquisa realizada pela USEPA $(U . S$. Environmental Protection Agency, 1992) constatou em território norte americano cerca de 75 000 crianças expostas a água com presença de $\mathrm{NO}_{3}{ }^{-}$.

As formas de $\mathrm{P}$ encontradas na natureza são diversas, sendo as mais comuns os ortofosfatos (disponíveis para os microorganismos sem necessidade de conversão a formas mais simples) representados pelos radicais $\mathrm{PO}_{4}{ }^{3-}, \mathrm{HPO}_{4}{ }^{2-}$ e $\mathrm{H}_{2} \mathrm{PO}_{4}{ }^{-}$, polifosfato (moléculas mais complexas com dois ou mais átomos de $\mathrm{P}$ ) e $\mathrm{P}$ orgânico (normalmente de menor importância) (STUMM; MORGAN, 1996). "O fósforo é essencial à vida aquática e ao crescimento de microorganismos responsáveis pela estabilização da matéria orgânica, e na forma de fosfatos dissolvidos é um importante nutriente para produtores primários" (PEREIRA, 2004, p.30). A disponibilidade do P para o meio aquático depende das rochas fosfatadas e dos ciclos internos dos lagos, influenciadas pela decomposição e excreção de organismos (TUNDISI; TUNDISI, 2008). O "lançamento de despejos ricos em fosfatos num curso d'água pode, em ambientes com boa disponibilidade de nutrientes nitrogenados, estimular o crescimento de micro e macroorganismos fotossintetizadores" (PEREIRA, 2004, p. 30) desencadeando florações indesejáveis e consequentemente, diminuir a biodiversidade local (eutrofização). Por outro lado, em sistemas lóticos com altas concentrações de material suspenso, este nutriente é retirado do ambiente na sua forma solúvel por adsorção ficando indisponibilizado aos produtores primários (PEREIRA, 2004). As maiores fontes não pontuais de nutrientes para os ecossistemas aquáticos são as áreas cultiváveis. Se forem regiões ausentes de práticas conservacionistas de uso do solo, a entrada de $\mathrm{P}$ se torna um problema maior como constataram Donadio, Galbiatti e de Paula (2005) ao analisarem a qualidade das águas do Córrego Rico/SP. Os ortofosfatos têm a característica de formar complexos estáveis com o $\mathrm{Al}, \mathrm{Fe}, \mathrm{Mg}, \mathrm{SO}_{4}{ }^{2-}, \mathrm{CO}_{3}{ }^{2-}, \mathrm{F}^{-}$e espécies orgânicas. No entanto, isso depende de alguns fatores relacionados a concentrações relativas de $\mathrm{PO}_{4}{ }^{3-}$, dos íons metálicos, do $\mathrm{pH}$ e da presença desses ligantes (WETZEL, 2001).

Os íons de $\mathrm{SO}_{4}{ }^{2-}$ são encontrados na água devido à lixiviação das rochas sedimentares, sua distribuição é fortemente influenciada pela formação geológica tornando-o um dos elementos mais abundantes na natureza. As maiores fontes provém da $\mathrm{CaSO}_{4} \cdot 2 \mathrm{H}_{2} \mathrm{O}, \mathrm{CaSO}_{4}$, oxidação de matéria orgânica e rejeitos industriais. "Em ambientes próximos ao mar, as 
concentrações de sulfato são maiores, já que nos oceanos o sulfato é mais abundante" (PEREIRA, 2004). Calvin (2008), ao correlacionar diversos parâmetros na bacia hidrográfica de Louisiana (EUA) presenciou fortes indicativos constituintes de alterações aquáticas oriundas da presença de $\mathrm{SO}_{4}{ }^{2-}, \mathrm{Na}$ e nutrientes $\mathrm{NO}_{3}{ }^{-}, \mathrm{NO}_{2}{ }^{-}, \mathrm{NH}_{4}{ }^{+}$e $\mathrm{PO}_{4}{ }^{3-}$.

No referido estudo de Calvin (2008), as quantidades de $\mathrm{SO}_{4}{ }^{2-}$ variavam muito, altos níveis ocasionais foi encontrado na porção sul da bacia, local afetado por águas salobras marinhas do Lago Pontchartrain. As águas da respectiva região eram influenciadas pela precipitação e pela água doce proveniente de insumos, apresentando diferentes graus de concentração do elemento ao longo do ano. Encontrou também elevados teores vindos de fontes pontuais onde havia laticínios e áreas agrícolas ou acelerado desenvolvimento urbano. Fato que preocupa, pois, ao se referir à saúde humana, o $\mathrm{SO}_{4}{ }^{2-}$ é um elemento que induz o organismo a efeitos laxativos se utilizado em águas para abastecimento público (PEREIRA; FILHO; DANTAS, 2011). Na rede de esgoto, ele pode ser transformado em $\mathrm{H}_{2} \mathrm{~S}$, ocorrendo a exalação do gás sulfídrico, principalmente em trechos de baixa declividade ou onde se deposita a matéria orgânica. Tal ácido pode corroer os coletores de esgoto, causar odor, além de ser tóxico.

\subsection{Oxigênio Dissolvido (OD), Demanda Bioquímica de Oxigênio (DBO) e Indicadores Bacteriológicos (IB)}

As análises físico-químicas e bacteriológicas avaliam as características da água refletindo seu padrão qualificando-a sob aspectos geológicos e higiênico-sanitários (CEBALLOS et al., 1995; STURMER et al., 2001). A interrelação entre os parâmetros possibilita um diagnostico da atual situação em que se encontra o sistema hídrico ao fornecer ferramentas necessárias sobre variações ocorridas através da combinação de parâmetros de diferentes dimensões (BONNET; FERREIRA; LOBO, 2008). O OD, a DBO e os IB estabelecem uma correlação ímpar estando interligadas entre si. O OD é essencial à manutenção do equilíbrio no ambiente aquático e sua disponibilidade pode ser medida pela DBO utilizada na estabilização da matéria orgânica pela ação catalisadora de microrganismos aeróbios. Assim, a introdução de compostos orgânicos além da capacidade de depuração do meio, prolifera a ação microbiológica reduzindo os teores de $\mathrm{O}_{2}$ que vão suprir a DBO, tornando o sistema hídrico alterado em relação ao seu estado normal (MACEDO, 2007). 
Favorecidas pelos intensos processos de decomposição e respiração, as bactérias heterotróficas contribuem para a diminuição na concentração de $\mathrm{pH}$ em um ambiente aquático. Consequentemente há a liberação de $\mathrm{CO}_{2}$ que gera a formação de $\mathrm{H}_{2} \mathrm{CO}_{3}, \mathrm{H}^{+}$, processos metabólicos de nitrificação, presença de ácidos orgânicos e inorgânicos dentre outros (ESTEVES, 1998). Situações favoráveis de temperatura, entrada de substâncias diversas e presença de nitrogenados também colaboram para o desenvolvimento dessas bactérias. Tais bactérias requerem o carbono orgânico como fonte de nutrientes e são causadoras de odores desagradáveis característicos da redução do $\mathrm{SO}_{4}{ }^{2-}$ em $\mathrm{H}_{2} \mathrm{~S}$ (METCALF; EDDY, 1979; BRASIL, 2006).

As bactérias heterotróficas geralmente não são patogênicas, porém, a densidade destas pode comprometer a detecção das bactérias do grupo coliforme, utilizadas como indicadoras de esporos de origem fecal e patogênicas (BRASIL, 2006). Dentre os organismos de referência fecais mais utilizados está a da Escherichia Coli, bactéria que ocupa um lugar privilegiado com "presença garantida nas fezes humanas e animais homeotérmicos com percentuais em torno de 96 a 99\%" (GLEESON; GRAY, 1997). Também reúne todas as exigências descritas por Santos (2010) ao atender a requisitos como:

- “ser aplicável a todos os tipos de água;

- $\quad$ ter uma população mais numerosa no ambiente que os demais patógenos;

- $\quad$ sobreviver mais que os possíveis patógenos (especialmente importante na avaliação da água clorada);

- ter como habitat natural apenas o trato intestinal humano ou de outros animais homeotérmicos;

- não se multiplicar facilmente fora deste ambiente;

- $\quad$ ser facilmente evidenciado por técnicas laboratoriais simples".

A escolha de microorganismos apontadores de mudanças consideráveis na água é habitualmente utilizada, pois a detecção de organismos patogênicos exige metodologias complexas, onerosas e a obtenção dos resultados demandam muito tempo (MACEDO, 2007). Os indicadores bacteriológicos assumem relevante importância e são encontrados em locais que recebem efluentes de esgoto doméstico ricos em matéria fecal caracterizando águas potencialmente perigosas à saúde humana (GRAY, 1995; WHO, 2004). A presença da Escherichia Coli, um bastonete gram-negativo, por exemplo, causa várias doenças como 
gastroenterite, meningite neonatal, infecções das vias urinárias e sepse. Jawetz et al. (2009) destacaram ainda que $90 \%$ das infecções de vias urinárias em mulheres jovens e a maioria das infecções hospitalares são causadas por este microorganismo.

Microorganismos patogênicos podem agregar-se a partículas sólidas de suspensão presentes em altos valores de turbidez provocando sua difusão, absorção e reduzindo a penetração da luz interferindo diretamente na fotossíntese, além de diminuir a eficiência da desinfecção da água utilizada para abastecimentos públicos (SPERLING, 1996). Existe a ainda a possibilidade de crescimento bacteriano, uma vez que cada microrganismo possui uma faixa ideal de temperatura, proveniente da elevação da temperatura desencadeada pela introdução de poluição térmica ou esgoto. Em temperaturas altas, a solubilidade dos sais minerais é maior e há a diminuição da solubilidade dos gases, viscosidade da água, tensão superficial, calor específico, compressibilidade, calor latente de vaporização e constante de ionização.

\subsection{Elementos: Ca, Mg, Na, K, F, Cl, Si, Al}

As principais fontes de Ca são os minerais feldspatos, anfíbolas, plagioclásios cálcicos, $\mathrm{CaCO}_{3}, \mathrm{CaMg}\left(\mathrm{CO}_{3}\right)_{2}, \mathrm{CaSO}_{4} \cdot 2 \mathrm{H}_{2} \mathrm{O}$ e $\mathrm{CaF}_{2}$. Este elemento pode aparecer em quantidades variadas também em argilitos, siltitos e arenitos (WEDEPOHL, 1978). Com exceção das rochas carbonatadas compostas basicamente por $\mathrm{CaCO}_{3}$, os teores médios de Ca variam entre 0,9\% e 7,4\%. Em solos cuja presença é abundante, ele acaba por inibir a disponibilidade do Fe (REIMANN; CARITAT, 1998). Sua presença em sistemas aquáticos se dá principalmente pela passagem da água em depósitos de pedra calcária ou outra que contém o elemento, assumindo a forma de $\mathrm{HCO}_{3}{ }^{-}$. A quantidade de Ca expressa na água do mar é cerca de $20 \%$

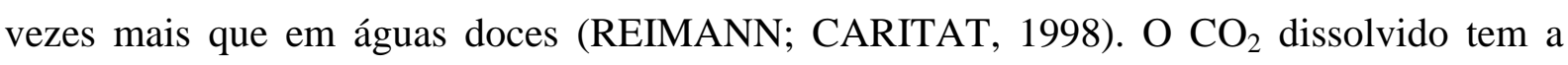
função de solubilizá-lo, contudo, isso depende da influência da temperatura e da pressão. $\mathrm{O}$ Ca é o principal elemento responsável pela dureza da água e apresenta mobilidade muito elevada.

$\mathrm{O} \mathrm{Mg}$, diferente do $\mathrm{Ca}$, forma sais mais solúveis sendo amplamente distribuído na natureza em minerais como magnesita, brucita, dolomita e carnalita. Predominam-se maiores quantidades de $\mathrm{Mg}$ em rochas que em solos (AIKAWA; MERIAN, 1991). Nas águas subterrâneas, as fontes fornecedoras mais comuns se encontram em rochas como: biotita, 
anfibólios e piroxênios. Estes minerais são mais estáveis diante do intemperismo químico, explicando assim seu menor percentual em relação ao Ca.

O Na é um dos elementos mais abundante na terra, possivelmente se faz presente na maioria das águas naturais por ser altamente solúvel e, os minerais que o contém, pouco resistentes ao intemperismo. Como há sensíveis variações no arranjo químico das rochas é de se esperar certa relação entre sua composição na água e na rocha da área. Também, a geologia e o tipo de água influenciam na disposição do Na. Branco (2011) destaca que áreas litorâneas apresentam níveis elevados de $\mathrm{Na}, 10 \mathrm{mg} \mathrm{L}^{-1}$ ou mais, em salmoura natural em decorrência das intrusões marinhas. Nas águas subterrâneas o teor varia entre 0,1 e $100 \mathrm{mg} \mathrm{L}^{-1}$ e frequentemente excede $50 \mathrm{mg} \mathrm{L}^{-1}$, considerando que há um enriquecimento gradativo deste metal a partir das zonas de recarga (KEMERICH et al., 2013). Muitas águas superficiais, incluindo aquelas que recebem efluentes, têm níveis bem abaixo de $50 \mathrm{mg} \mathrm{L}^{-1}$ (PROCHNOW; PROCHNOW; LIBERMAN, 2009). O Na é um elemento ativo para os organismos vivos, assim ele é frequentemente medido onde a água é utilizada para dessedentação de animais ou para agricultura. "Em plantas, sua concentração é bastante variável, regionalizada, parecendo não afetar estes organismos do mesmo modo que afeta animais, podendo apresentar-se de 0,003 até 0,3\% em peso" (PROCHNOW; PROCHNOW; LIBERMAN, 2009). Valores acima de $200 \mathrm{mg} \mathrm{L}^{-1}$ pode dar à água um gosto não aceitável e em certos tipos de solo onde seu teor é elevado, sua estrutura pode degradar-se afetando o desenvolvimento das plantas. "É um contaminante ambiental amplamente ligado às atividades antrópicas" (PROCHNOW; PROCHNOW; LIBERMAN, 2009). O aumento das concentrações de Na na água advém de seu uso na agricultura, lançamentos de esgotos domésticos, rejeitos industriais e do uso sazonal de sais em rodovias para controlar neve e gelo, principalmente nos países da América do Norte e Europa.

$\mathrm{O} \mathrm{K}$ é um elemento químico abundante na crosta terrestre e deficiente em águas subterrâneas. "[...] está presente em solos em teores que variam de 0,02\% a 0,20\% e, em águas, sua concentração pode ficar entre 0,5 e 1,0 mg L $\mathrm{m}^{-1}$ " ( PROCHNOW; PROCHNOW; LIBERMAN, 2009). Apresenta-se na forma iônica sendo altamente solúvel e incorporado nas estruturas das rochas ou acumulado pela biota aquática devido ao seu valor nutricional. Ele provém de minerais como: feldspato potássico, mica moscovita e biotita. Sua facilidade de fixação em argilas e intensivo consumo pelos vegetais, aliado à resistência relativa de suas rochas às ações intempéricas, o faz um elemento pouco disponível em águas naturais. 
Entretanto, esses percentuais podem aumentar pelo uso de $\mathrm{K}$ "na indústria e em fertilizantes para lavoura, entrando nas águas doces através das descargas industriais e lixiviação das terras agrícolas" (BRANCO, 2011).

O F encontra-se em pequenas quantidades na forma de $\mathrm{F}^{-}\left(0,1\right.$ a 2,0 $\left.\mathrm{mg} \mathrm{L}^{-1}\right)$. Surge nos sistemas aquáticos através dos minerais: fluorita, apatita, flúor-apatita, turmalina, topázio e mica. Diferente de outros halogênios constitui complexos estáveis com o $\mathrm{Al}, \mathrm{Fe}, \mathrm{B}$ e $\mathrm{Ca}$ e pode ser removido das águas coprecipitado aos óxidos ou complexados de fosfato. Na saúde humana, promove o endurecimento da matriz mineral dos dentes e esqueleto se fazendo eficiente na prevenção de cáries, mas, valores elevados indicam prejuízos, tanto para seres humanos quanto para animais (ANDREAZZINI; FIGUEIREDO; LICHT, 2006). Certas raízes e turbéculos como mandioca (Manihot esculenta e Manihotdulcis), inhame (Dioscorea), cará (Colocasia esculenta), apresentam níveis relativamente altos de $\mathrm{F}^{-}$, e também folhas de chá. Esses vegetais são constituintes básicos da dieta em muitas regiões tropicais, sobretudo na América do Sul e no Pacífico. Fonseca Janaína, Marchi e Fonseca Jassyara (2008) afirmam que "produtos de peixe, em particular os enlatados, como as sardinhas, [...], chegam a apresentar $40 \mathrm{mg} \mathrm{kg}^{-1}$ de fluoreto”. Vale ressaltar, a quantidade máxima permitida varia de acordo com a idade do consumista e a ingestão diária. Se o $\mathrm{F}$ for adicionado aos sistemas de abastecimento público deve-se ter um rigoroso controle na sua quantidade, principalmente onde o consumo de água se fizer maior como é o caso dos países tropicais.

Todas as águas naturais, em maior ou menor escala, contêm íons de $\mathrm{Cl}^{-}$resultantes da dissolução de sais. Eles se encontram na forma de sólidos diluídos naturalmente ou por meio de ações humanas no lançamento de efluentes. Seu teor é elevado em esgotos uma vez que o $\mathrm{NaCl}$ está presente na urina, dependendo da composição destes, pode variar de 20 a 100 $\mathrm{mg} \mathrm{L}^{-1}$. "Teores anômalos são indicadores de contaminação por água do mar e por aterros sanitários" (VIANA et al., 2009). O íon $\mathrm{Cl}^{-}$é o ânion inorgânico que mais ocorre, seu poder reativo além de alterar o equilíbrio do sistema, pode comprometer a potabilidade da água e potencializar corrosões em tubulações (KEMERICH et al., 2013).

O Si é o segundo elemento mais abundante da superfície terrestre sendo superado em quantidade apenas pelo $\mathrm{O}_{2}$ (COTTON et al., 1999). Os cristais ultrapuros de sua formação apresentam brilho metálico azul acinzentado (EMSLEY, 1998). Em temperatura ambiente é um mau condutor de calor e eletricidade enquanto que a altas temperaturas ele se torna bom 
adutor (CSUROS; CSUROS, 2000). Seu constituinte mais importante é o $\mathrm{SiO}_{2}$ encontrado na maioria das rochas e cujo mineral típico é o quartzo. Outros minerais ricos em $\mathrm{SiO}_{2}$ são os feldspatos, as micas e outros silicatos. As associações naturais deste elemento são essencialmente com o Al (DEER; HOWIE; ZUSSMAN, 1966; REIMANN; CARITAT, 1998).

O Al não acontece naturalmente no estado elementar. Ele é distribuído amplamente pela superfície em combinação com $\mathrm{O}_{2}$ e $\mathrm{H}$ (bauxita), complexado com o $\mathrm{Na}$ e $\mathrm{F}^{-}$(criolita), silicatos (feldspatos e micas) e outros componentes. Está nas rochas em geral e nos solos varia muito com o tipo de material originário e com o pH dos mesmos. Segundo Siegel (1979), rochas ígneas possuem a variância de $2 \%$ e rochas ultrabásicas 8,8\%. Nas rochas sedimentares o conteúdo de $\mathrm{Al}$ torna-se mais expressivo em argilitos $(8 \%)$ e bastante baixo em $\mathrm{CO}_{3}{ }^{2-}$ $(0,42 \%)$. Em solos de $\mathrm{pH}$ inferior a 5,5, principalmente argilosos, a competição de $\mathrm{Al}^{3+}$ com os cátions de outros elementos faz com que ocorra a substituição dos átomos de $\mathrm{Al}$ ou outros trivalentes por $\mathrm{Si}$, gerando um excesso de cargas negativas na superfície desses agregados (KABATA-PENDIAS; PENDIAS, 2001). A exposição deste elemento à água e aos oxidantes proporciona-lhe uma resistência à corrosão e alta reatividade combinando-se com outros elementos (WHO, 1997), isso é possível por causa da camada superficial de $\mathrm{Al}_{2} \mathrm{O}_{3}$ que lhe é formada. Dentre os óxidos e hidróxidos de alumínio, se destacam a $\mathrm{Al}(\mathrm{OH})_{3}$, a $\mathrm{Al}_{2} \mathrm{Si}_{2} \mathrm{O}_{5}(\mathrm{OH})_{4}$, a $\mathrm{Al}_{2} \mathrm{SiO}_{5}$ e o $\mathrm{Al}_{2} \mathrm{O}_{3}$ (CSUROS; CSUROS, 2000). Ele é considerado um elemento essencial para certos organismos, sendo, no entanto, tóxico para os peixes a $\mathrm{pH}$ baixo e prejudicial a humanos sob forma de íons livres (REIMANN; CARITAT, 1998).

\subsection{Elementos-Traço}

Os metais-traço são elementos não degradáveis, podem ser encontrados na solução do solo, adsorvidos eletrostaticamente aos sítios de troca, incorporados à superfície da fase inorgânica na forma de óxidos de $\mathrm{Al}, \mathrm{Fe}$ e de $\mathrm{Mn}$ ou ligados a compostos orgânicos. Eles prevalecem como nutrientes essenciais em pequenas quantidades para o desenvolvimento da biota, assim como dos seres humanos (HOODA, 2010). A reconhecida importância dos metais-traço para cultivo e nutrição de gado é conhecida a anos (WEBB, 1975). Normalmente são utilizadas faixas muito estreitas e dosagens bem calculadas. Licht (2001) e Selinus et. al. (2005) ao justificarem seu uso, salientaram que a "deficiência e/ou excesso de metais como o 
$\mathrm{Cu}, \mathrm{Zn}, \mathrm{Mo}, \mathrm{Co}, \mathrm{Se}, \mathrm{Fe}, \mathrm{Mn}$ e Cr podem levar ao fracasso do plantio ou à morte dos animais”. Martins et al. (2011) explicaram a importância dessa observação, acrescentando que esses elementos podem vir a constituir uma fonte potencial para a poluição ambiental, passando de micronutrientes à condição de elementos tóxicos visto às propriedades prejudiciais de bioacumulação que possuem.

Dentre os diversos metais-traço, o Fe e o Mn, possuem características bem específicas quanto à capacidade de sorção, são mais elevadas em relação aos demais óxidos e hidróxidos e se dissolvem quando o potencial redox decresce e precipitam à medida que o sistema se oxigena. Estes elementos tendem a manter os óxidos de $\mathrm{Fe}$ e $\mathrm{Mn}$ com baixo grau de cristalinidade, apesar de ser bastante ativos (JENNE, 1968), isso proporciona facilidade na incorporação de íons estranhos em sua estrutura. O Mn é encontrado naturalmente em rochas ígneas (CARVALHO, 2006). "Geralmente ocorre no meio natural como $\mathrm{Mn}^{2+}$ (em solução, hidratado ou como cátion adsorvido), $\mathrm{Mn}^{3+}$ (bastante reativo) e como $\mathrm{Mn}^{4+}$ (óxidos de grande estabilidade)" (NASCIMENTO; HYPOLITO; RIBEIRO, 2006). Grande quantidade de Mn pode provocar distúrbio neurológico em humanos através de exposições crônicas ao ar. Em meio aquático assume a coloração negra, com predominância dos estados de oxidação $\mathrm{Mn}^{2+} \mathrm{e}$ $\mathrm{Mn}^{4+}$, sendo o primeiro mais solúvel. Ele é extremamente sensível às variações de $\mathrm{pH}$ e Eh. Alloway (1995) chega a dizer que a elevação de uma unidade do $\mathrm{pH}$, por exemplo, causa diminuição na concentração de Mn (total) cerca de 100 vezes. Segundo WHO (1981) o minério Mn pirolusita com $40 \%$ a $80 \%$ de $\mathrm{MnO}_{2}$ é o de maior ocorrência na natureza. Sua forma oxidada e precipitação cresce com o aumento do $\mathrm{pH}$.

$\mathrm{O}$ Fe ocorre quase sempre em conjunto com Mn vindo da dissolução de compostos ferrosos de solos arenosos, terrenos de aluvião ou pântanos. Suas fontes são minerais escuros (máficos) como a magnetita, biotita, pirita, piroxênios, anfibólios. Em concentrações elevadas, se caracteriza um problema de qualidade da água na irrigação localizada. O Fe na forma reduzida $\left(\mathrm{Fe}^{2+}\right)$ torna-se solúvel sob a forma iônica ou $\mathrm{CO}_{3}{ }^{2-}$, e na forma oxidada $\left(\mathrm{Fe}^{3+}\right)$ encontra-se, consideravelmente precipitado ou complexado na forma de hidróxido de ferro hidratado. Segundo Esteves (1998), isso acontece sob influência da interação que este elemento tem com bactérias filamentosas dos gêneros Gallionella e Leptothrix. Ford e Tucker (1986), acreditam que apenas concentrações acima de $0,4 \mathrm{mg} \mathrm{L}^{-1}$ de Fe utilizada em sistema de irrigação localizado é que pode provocar o desenvolvimento dessas bactérias férricas filamentosas. No entanto, Hernandez e Petinari (1998) caracterizaram um "grave problema, 
representado pela obstrução de 58,4\% da área interna de uma tubulação após apenas 25 meses de uso, impregnada por $0,354 \mathrm{~kg}$ de material seco de elevada concentração de ferro por metro de tubo de 50 mm" (FRANCO; HERNANDEZ, 2009). Nas águas superficiais, o nível de Fe aumenta nas estações chuvosas devido ao carreamento de solos, a ocorrência de processos de erosão das margens e a contribuição de efluentes industriais. O excesso de Fe pode resultar doenças hepáticas, cardíacas, diabetes, disfunções hormonais e do sistema imunológico e mesmo doenças crônico-degenerativas, bem como alterações na pigmentação da pele (SIQUEIRA; ALMEIDA; ARRUDA, 2003; LIEU, et al., 2001).

\subsection{Mobilidade e Dispersão dos Elementos}

A mobilidade dos elementos químicos no ambiente tem como fundamento a propriedade de apresentar agrupamentos ou perdas no ambiente proporcionado a sua movimentação. "Um guia aproximado para a mobilidade é dado pelo potencial iônico, obtido pelo quociente da carga iônica pelo raio iônico" (LICHT, 2001). Fatores como pH, Eh, granulometria, regime hidrológico, propriedades químicas dos elementos e dissolução dos minerais são influenciadores em seu comportamento (LICHT, 1998; TABOADA et al., 2006). Quando o pH é extremamente ácido $\left(\mathrm{H}^{+} \mathrm{em}\right.$ quantidade maior no meio), o íon férrico liberado da destruição de minerais como micas, epidotos, hornblendas e cloritas é encontrado em solução. Porém, se o pH aumenta por possível neutralização de $\mathrm{CO}_{3}{ }^{2-}$, o $\mathrm{Fe}$ solúvel se precipita. Dessa forma, em meios ácidos, podem ser encontrados elementos em solução, o que em meios alcalinos isso não seria possível evidenciando a importância do estudo do $\mathrm{pH}$ nos sistemas aquáticos (REBERTUS; BUOL, 1985).

A granulometria também influi na maior ou menor mobilidade e distribuição dos elementos. Rochas formadas por grãos maiores se desintegram com mais facilidade que outras formadas por grãos pequenos. Dependendo da desagregação e dos processos físicoquímicos, essa desestruturação das rochas e do solo pode levar a aberturas de sulcos, ravinas e voçorocas. A coloração da rocha é uma característica a se considerar. Rochas escuras, por se aquecerem mais, se desagregam com facilidade. Do mesmo modo, rochas de cor uniforme são menos susceptíveis a se fragmentarem do que rochas de coloração variada. $O$ intemperismo juntamente com a dispersão seletiva de componentes da rocha matriz promove a maior ou menor mobilização dos elementos (LICHT, 1998). O $\mathrm{TiO}_{2}$ e o $\mathrm{ZrSiO}_{4}$ são alguns 
dos minerais considerados resistentes aos processos intempéricos, portanto, possui pouca mobilidade. "Se a resistência ao intemperismo do mineral que contém o elemento químico é alta, a mobilidade tende a ser menor" (HOLANDA; BUENO, 2010). A dispersão hidromórfica de um elemento pode ocorrer na forma de íons livres, ou seja, baixo potencial iônico $(\mathrm{Ca}, \mathrm{Na}, \mathrm{Cu}, \mathrm{Zn}, \mathrm{Pb})$ ou como íons complexos, potenciais iônicos muito elevados que se combinam com o $\mathrm{O}_{2}$ e formam oxi-ânions solúveis $\left(\mathrm{PO}_{4}{ }^{2-}, \mathrm{SO}_{4}{ }^{2-}, \mathrm{MoO}_{4}{ }^{2-}\right)$. Os elementos com potencial iônico intermediário, Al, Ti e Sn, possuem forte tendência à adsorção em superfícies, tornando-se imóveis em virtude de sua baixa solubilidade. Diferenças no estado de oxidação (valência) também resultam em mobilidades diferentes (ROSE; HAWKES; WEBB, 1979).

Segundo Jesus et al. (2004), a disponibilidade dos metais depende de quão forte for a interação ligante/suporte. $\mathrm{O} \mathrm{Fe}^{2+}$ e o $\mathrm{Mn}^{2+}$ são oxidados mais facilmente $\mathrm{F} \mathrm{Fe}^{3+}$ e $\mathrm{Mn}^{3+}$ ou $\mathrm{Mn}^{4+}$ respectivamente em ambientes com alto redox (GARRELS; CHRIST, 1965), assim é comum encontrar estes elementos sob a forma de óxidos ou hidróxidos. Os óxidos hidratados de Fe e Mn uma vez formados têm a tendência de capturar ou adsorver elementos com os quais entrem em contato. Na Uganda, por exemplo, as águas do córrego Nakivubo não foram alteradas, apesar do enriquecimento de $\mathrm{Pb}$ e $\mathrm{Mn}$ presentes nos efluentes lançados em suas águas. Tais elementos sofreram imobilização dentro do meio aquático na forma de oclusão ou incorporação na coprecipitação de óxidos (SEKABIRA et al., 2010). No entanto, metais precipitados ou adsorvidos podem ser liberados por ataques químicos suaves (chuva ácida) ou ácidos fortes dependendo da hidratação do suporte e do tempo de ligação. Além da capacidade de adsorção mais elevadas, à medida que o potencial redox decresce a capacidade de adsorção do $\mathrm{Fe}$ e do $\mathrm{Mn}$ se dissolve e precipita à medida que o sistema se torna mais oxigenado (JENNE, 1968). Essa característica os coloca em uma posição privilegiada em relação aos óxidos de $\mathrm{Al}$ e Si nos estudos geoquímicos.

\subsection{Métodos Geoquímicos na Avaliação dos Recursos Hídricos}

Os métodos geoquímicos vêm sendo praticado desde 1930 e intensificado a partir de 1970 em áreas urbanizadas ou com forte influência antrópica. O sucesso da nova metodologia provocou rápida disseminação por vários países sendo pesquisada e aplicada com êxito em diferentes ambientes geológicos e fisiográficos do planeta (SILVA; GALVÍNCIO; 
ALMEIDA, 2010). Sua importância se dá ao fato de estudar a química da Terra como um todo e cada um dos seus componentes em particular, bem como a distribuição e migração no espaço e no tempo dos elementos químicos (GUEDES, 2012a).

Licht (1998) subdivide esta ciência (a geoquímica) em dois ciclos baseados nos seus respectivos ambientes: o profundo e o superficial. O profundo constitui-se de processos magmáticos e metamórficos que darão origem à cristalização de minerais, formação e transformação das rochas. No superficial, ocorrem processos de modificação por erosão, sedimentação, agentes biológicos e antrópicos, sendo estes, os mais atuantes na crosta e presentes na composição química da água e sedimentos de fundo. Defini-se sedimentos de fundo as partículas não consolidadas de rochas, solos ou restos de biota em decomposição distribuída ao longo dos vales do sistema de drenagem e orientada a partir da interação constante e contínua dos processos de erosão (GUEDES 2012a). As amostras de sedimento de rios, lagos e lagoas representam a relação de todos os processos que ocorrem no ecossistema aquático à montante (OWENS, 2005) e podem elucidar a poluição atribuída aos elementostraço e/ou substâncias tóxicas orgânicas por representar o principal compartimento de geoacumulação ou transferência de elementos. Reforçando essa teoria, Pereira et al. (2007) ao mencionarem a distribuição dos íons metálicos e os metalóides entre as fases solúveis, coloidal ou material em suspensão, afirmam que apenas $1 \%$ das espécies químicas orgânicas e inorgânicas se concentra dissolvidas em água e mais de 99\% são estocadas no compartimento sedimentar.

\subsection{Métodos Analíticos para Determinação de Metais em Água e Sedimentos}

A determinação de metais em sedimentos abrange vários métodos analíticos, tais como: espectroscopia de absorção atômica, análise por ativação de nêutrons, fluorescência de raiosX, espectroscopia de emissão atômica e métodos polarográficos (FÖRSTNER, 1980). Quando as concentrações de metais e metalóides são muito baixas recomenda-se a utilização de técnicas sensíveis (PETRY, 2005). Dentre estas, a Espectrometria de Emissão com Plasma Indutivamente Acoplado (ICP/OES) representa um dos maiores avanços em tecnologia analítica dos últimos tempos, no que diz respeito à determinação de metais. Esta técnica possibilita baixos limites de detecção, resultados rápidos e precisos para um grande número 
de elementos químicos, em determinações sequenciais ou simultâneas e ainda, a obtenção de grande número de dados para diversos estudos (BOAVENTURA, 1991).

A espectrometria de emissão com plasma indutivamente acoplado é uma técnica espectroscópica convencional onde a introdução do analito em solução é submetida a altas temperaturas, causando a dissociação e a excitação (ou ionização) dos átomos da amostra sendo possível a observação da emissão do espectro (CEOTTO, 2009). Sua propriedade única deriva da fonte de excitação utilizada, o plasma indutivamente acoplado. O plasma consiste de um gás com uma significante fração de átomos ou moléculas ionizadas. O gás ionizado ou plasma é um condutor elétrico e pode ser rapidamente aquecido por campo magnético indutivamente acoplado (PETRY, 2005). Segundo Petry (2005) a capacidade multielementar da técnica de ICP/OES permite a determinação de aproximadamente 70 elementos em uma ampla variedade de amostras.

\subsection{Análise Mineralógica por Difração de Raio-X para Estudo do Sedimento de Fundo}

O sedimento, em geral, é caracterizado por seu conteúdo químico-mineralógico e a difração de raios-X informa sobre sua composição (DIAS, 2004). Os raios-X são radiações eletromagnéticas que podem ser polarizadas, difratadas, refratadas e refletidas. A difração, resultante de um cristal compreendendo posições e intensidades das linhas de difração, é uma propriedade física fundamental da substância, servindo não só para a identificação como também ao estudo de sua estrutura. As radiações mais usadas na difração de raios-X são as $\mathrm{K} \alpha$, com comprimento de onda compreendida entre 0,56 e 2,29 A. Os tubos que geram essas radiações são de $\mathrm{Cr}, \mathrm{Mn}, \mathrm{Fe}, \mathrm{Co}, \mathrm{Ni}, \mathrm{Cu}, \mathrm{Mo}$ e $\mathrm{Ag}$, sendo que o mais utilizado é o de $\mathrm{Cu}$ (PUC-RIO, 2013). Uma das grandes aplicações da difração de raios-X consiste na identificação e no estudo dos argilominerais. Dentre as vantagens da técnica de difração de raios $\mathrm{X}$, destaca-se a simplicidade, rapidez do método e a confiabilidade dos resultados obtidos (ALBERS, 2002). A difratometria de raios $\mathrm{X}$ corresponde a uma técnica de caracterização microestrutural de compostos cristalinos, sejam eles inorgânicos ou orgânicos.

A composição e as fases cristalinas são parâmetros fundamentais para a caracterização de solos, sedimentos e argilas (SCAPIN, 2003). É a técnica mais indicada, considerando que na maioria dos sólidos (cristais), os átomos se ordenam em planos cristalinos separados entre si por distâncias da mesma ordem de grandeza dos comprimentos de onda dos raios $\mathrm{X}$ 
(ALBERS, 2002). Essa interferência construtiva ocorre apenas nas direções de empalhamento dos feixes que satisfazem a Lei de Bragg, quando o espalhamento e a radiação incidente possuem o mesmo comprimento de onda. A análise de DRX relaciona a distância interplanar $(d)$ a qual corresponde a distância entre camadas sucessivas ao longo do plano, com o comprimento de onda e os ângulos de incidência e reflexão da onda com o plano (PUC-RIO, 2013).

Os argilominerais geralmente são de granulometria menor que $2 \mathrm{~mm}$ e desempenham um papel importante na mobilidade dos elementos no ambiente superficial devido a sua capacidade sortiva. A capacidade sortiva está relacionada à facilidade dos argilominerais em receber moléculas de água ou cátions entre as lâminas que constituem sua estrutura (Licht, 1998). Ao se caracterizar os argilominerais, a utilização da técnica de DRX torna-se ainda mais indicada, pois uma análise química reportaria os elementos químicos presentes no material, mas não a forma como eles estão ligados (ALBERS, 2002).

\subsection{IQA e Uso dos Métodos: Geoquímicos, $I_{\text {geo }}$ e Estatísticos na Avaliação da Qualidade das Águas}

Bonnet, Ferreira e Lobo (2008), ao considerarem os fatores bióticos, abióticos, externos e internos (intemperismo, erosão, ocupação e uso do solo) numa dinâmica de perdas e ganhos, afirmam que há diferentes indicadores de qualidade de água para os sistemas hídricos. Partindo do pressuposto que o homem modifica significativamente o meio onde vive e as características peculiares de cada curso d'água, ao se avaliar o estado de conservação dos recursos hídricos por IQA's, “o ideal é a obtenção de índices de qualidade das águas que reflitam resumidamente e objetivamente as suas alterações, com ênfase para as intervenções humanas [...]" (COUILLARD; LEFEBVRE, 1985).

Um IQA é um número adimensional que exprime atributos da água. Esse número é obtido agregando-se dados físico-químicos e bacteriológicos através de metodologias especificas. Para Haase, Krieger e Possoli (1989) e Toledo e Nicolella (2002) é importante que os modelos geoquímicos sejam baseados em métodos estatísticos. Tais métodos auxiliam na definição dos parâmetros indicadores da qualidade evitando subjetividade na interpretação dos resultados. Primavesi et al. (2002) em seu estudo da qualidade da água do Ribeirão Canchim-SP fizeram uso da estatística multivariada na avaliação e notaram que o $\mathrm{pH}$, a 
alcalinidade e a dureza total se correlacionavam.

Os índices baseados em técnicas estatísticas ajudam a selecionar os indicadores mais influentes do sistema hídrico em estudo (HAASE; KRIEGER; POSSOLI, 1989). Serve ainda como instrumento de avaliação ao longo do tempo ou do espaço permitindo um acompanhamento das alterações ocorridas no eixo hidrográfico. Segundo Palácio et al. (2009) esse tipo de tratamento é muito utilizado para caracterizar e avaliar a qualidade das águas superficiais "sendo útil para evidenciar variações espaciais e temporais causadas por fatores naturais e antropogênicos vinculados à sazonalidade”.

Por meio da análise temporal é possível fazer um levantamento sistemático de dados em pontos de amostragem (localização dos pontos de coleta, escolha das variáveis, determinação da frequência e tipo de amostragem estatística) para acompanhar a evolução das condições da qualidade da água ao longo do tempo garantindo sua manutenção. Na análise espacial, observa-se o comportamento de certo parâmetro de qualidade para pontos situados ao longo de um mesmo corpo hídrico. Tal procedimento permite identificar trechos críticos, nos quais a qualidade da água se encontra comprometida em função de eventual sazonalidade de lançamentos poluidores ou alterações na vazão (HESPANHOL, 2009).

Atualmente são desenvolvidos modelos geoquímicos que variam de acordo com a geologia local servindo de referência a estudos realizados na própria região ou regiões que possuem formação geológica semelhantes. Os autores que trabalham com este tipo de aplicação acreditam alcançar resultados positivos ao combinarem uma série de fatores (água, solo, intemperismo) correlacionados à paisagem (urbanização, agricultura, indústria e outras). Neste modelo é levado em conta que a presença do homem e suas atividades produzem alterações no ambiente natural sendo identificáveis nos sedimentos de fundo. Considera-se também a forma de ocorrência e dispersão dos constituintes químicos e sua relação com processos de sorção em argilas, óxidos hidratados de Al, Fe, Mn e matéria orgânica. Assim, princípios de hidrodinâmica, como transporte e deposição, fazem com que haja acumulação desses resíduos em determinadas posições dos canais da rede de drenagem natural.

O método geoquímico é realizado em coletas de água, sedimentos e análises laboratoriais. Uma das formas empregadas para esses procedimentos é através de análises de amostras de água, uso de equipamentos específicos como ICP/OES, espectrofotometria UV/Visível, titulação automática e métodos volumétricos. Nos sedimentos utiliza-se ataque ácido para determinação dos elementos-traço e fusão de metaborato de lítio no caso dos 
elementos maiores. Também para sedimentos empregam-se técnicas de ICP/OES e EAA, a fração recomendada no preparo das amostras é $0,063 \mu \mathrm{m}$ concluindo com o estudo da mineralogia através do uso de DRX.

\subsection{Trabalhos Relacionados ao uso das Técnicas Geoquímicas e Estatísticas}

Diversos trabalhos evidenciaram a contribuição dessas técnicas. Hortellani et al., (2013) conseguiram distinguir as origens e as fontes antrópicas no estudo que realizou no reservatório Billings-SP. Segundo os autores, somente Fe e Co estavam associados com a composição natural do sedimento ou processos de intemperismo natural. Os outros elementos encontrados na amostra, $\mathrm{Al}, \mathrm{Cd}, \mathrm{Cr}, \mathrm{Cu}, \mathrm{Hg}, \mathrm{Mn}, \mathrm{Ni}, \mathrm{Pb}$, e $\mathrm{Zn}$ indicaram aumento em suas concentrações, sugerindo associação com fontes antropogênicas. Nessa pesquisa, quatro metodologias foram utilizadas: normas de qualidade de sedimentos $\left(\mathrm{SQG}_{\mathrm{S}}\right)$, índice de geoacumulação ( $\mathrm{I}_{\mathrm{geo}}$ ), índice de poluição metálica (MPI) e análises estatísticas. O "MPI identificou as áreas mais críticas em relação à concentração total de metais enquanto $\mathrm{I}_{\mathrm{Geo}}$ identificou o metal específico para cada área” (HORTELLANI et al., 2013).

Neves, Horn e Fraga (2008) a partir da análise geoquímica integrada solo, água e sedimentos, constataram a influência direta do substrato geológico como fonte de elementos químicos primários para o sistema. Pôde deste modo, inferir quais alterações teriam sido produzidas pelas atividades antrópicas nas margens e cabeceiras do Ribeirão das Pedras-MG que modificaram a distribuição e concentração desses metais no solo e na água. Segundo seu estudo, o conteúdo geoquímico dos solos apresentou localmente ocorrências naturais anômalas dos elementos $\mathrm{As}, \mathrm{Zn}, \mathrm{Pb} \mathrm{Cu}, \mathrm{Cr}, \mathrm{Cd}$, relacionados à mineralogia das rochas e processos pedogenéticos. No entanto, nos sedimentos de fundo a reflectância do substrato agregou aumento na quantidade de alguns deles e introdução de outros como forma de contaminações pontuais de $\mathrm{Cd}, \mathrm{Pb}, \mathrm{Hg}$, relacionados à atuação constante de garimpos. Notou também em períodos chuvosos um aumento proporcional aos teores de algumas substâncias químicas, especialmente de $\mathrm{Fe}$ e $\mathrm{Al}$ devido às altas taxas de lixiviação e turbidez das águas.

Mulholland, Boaventura e Araújo (2012) reforçaram que a análise geoquímica conjunta da água e sedimento pode fornecer dados importantes sobre a avaliação de impactos ambientais. Sua pesquisa em Paracatu-MG validou informações por meio da apreciação multivariada na interpretação dos resultados da qualidade de água. A conexão da análise dos 
componentes principais com a mineralógica e o índice de geoacumulação possibilitaram distinguir, de forma multielementar, as distintas influências ocasionadas pelos depósitos minerais na acumulação de metais nos sedimentos.

Dentre as metodologias estatísticas mais usadas, a que mais se destaca é a multivariada. Sua função é reduzir a dimensão dos dados ao apresentar os resultados visando melhor entendimento gráfico a duas ou três dimensões (LANDIM, 2011). Conforme o interesse da pesquisa, o método verifica como as amostras se relacionam (LANDIM, 2011). Palácio et al. (2009) e Oliveira et al (2012) empregaram o procedimento da análise multivariada em locais diferentes, Minas Gerais e Ceará respectivamente. Contudo, os estudos dos dois pesquisadores basearam-se apenas em análises de amostras de água. Mendonça e Marques (2011) chamaram a atenção para o cuidado com estudos voltados à qualidade de águas embasado somente em diagnósticos laboratoriais isolados. Segundo eles, este tipo de estudo torna duvidoso o resultado das análises devido sua caracterização fornecer um panorama somente no instante da coleta, não detectando, portanto, despejos descontinuados e clandestinos.

Dos métodos da multivariada, destaca-se a análise de agrupamento hierárquico (HCA), no qual o tratamento matemático de cada amostra é definido por um ponto no espaço multidimensional descrito pelas variáveis escolhidas. Através deste ponto, é possível calcular a distância a todos os outros pontos, constituindo-se assim uma matriz que descreve a proximidade entre as amostras estudadas (MOITA NETO, 2004). Baseada nessa matriz se constrói um diagrama de similaridade, o dendograma, formado por HCA correspondente a um algoritmo específico. No dendograma, duas amostras próximas têm valores semelhantes para as variáveis medidas. Ele hierarquiza esta analogia e oferece uma visão bidimensional da similaridade ou dissimilaridade do conjunto de amostras utilizadas no estudo. Se, no entanto, têm-se variáveis de escalas diferentes, estas devem ser submetidas a um tratamento prévio dos dados. O pré-tratamento mais empregado é o que transforma as medidas de cada variável para que o conjunto de informações obtenha média zero e variância um. A finalidade deste procedimento é equalizar a importância estatística de todas as variáveis empregadas.

A análise quantitativa do enriquecimento dos elementos nos sedimentos pode ser avaliada através do Índice de geoacumulação $\left(\mathrm{I}_{\mathrm{geo}}\right)$ empregando valores de background tais como a média da região estudada, valores da área de controle ou média da crosta terrestre mundial. Em resposta a essa liberação físico-química transformadora do meio, os sedimentos 
tornam-se fontes difusas de contaminação da água e/ou auxiliar na avaliação dos teores existentes. Guedes (2012b) ao relacionar o ambiente natural com as atividades humanas desenvolvidas, justifica os excessos encontrados nos sistemas lóticos que interceptam áreas antropizadas a altas cargas de poluentes recebidas diariamente através deste método. O $\mathrm{I}_{\text {geo }}$ introduzido por Müller (1979), consta de uma equação logarítmica e um folhelho padrão dividido em 7 classes de poluição distribuídos em função dos graus que variam de 0 (não poluído) a 6 (altamente poluído). No estudo de Guedes (2012b), em Rio Jundiaí, Macaíba/RN, o $I_{\text {geo }}$ foi utilizado para cada ponto de amostragem (9 pontos), tomando como background geoquímico de referência este folhelho. Guedes (2012b) estava interessando em quantificar a presença de metais pesados (Al, Fe, Ba, $\mathrm{Co}, \mathrm{Cu}, \mathrm{Cr}, \mathrm{Pb}, \mathrm{Mn}, \mathrm{Ni}$ e $\mathrm{Zn}$ ). Nos pontos no trecho urbano a proporção das concentrações foram elevadas destacando $\mathrm{Pb}$ como o elemento de maior índice poluidor. A metodologia se deu a partir de amostragem de campo (chuvosa e seca) e fragmentação dos elementos químicos a partículas inferiores a 0,063 $\mu \mathrm{m}$, pois, enquanto menores, mais capacidade de adsorverem metais as partículas possuem. Os teores foram determinados nas respectivas amostras por ICP/OES.

Trabalho semelhante realizou-se no Ribeirão Piancó, Anápolis-GO por Borges (2009) para avaliar a qualidade dos sedimentos da bacia e suas implicações ao meio ambiente. No entanto, os pesquisadores determinaram apenas as concentrações dos constituintes menores $\mathrm{Cu}, \mathrm{Zn}, \mathrm{Co}, \mathrm{Ni}, \mathrm{Cr}$ em 12 pontos amostrados. Os resultados no Ribeirão Piancó assinalaram, indicadores de poluição correspondentes às intensidades, "praticamente não poluído" e "Moderado poluído", respectivamente para os sedimentos de fundo conforme o folheto padrão. Para o fator de contaminação, os metais-traço, $\mathrm{Cu}$, Ni e $\mathrm{Cr}$ não apresentaram contrastes tão significativos quando comparados com os valores relativos ao ponto de controle (P1). Desta forma, a geoquímica ambiental aliada a métodos estatísticos têm se mostrado importante nas pesquisas em sistemas aquáticos, validada também por outros pesquisadores como Licht (2001) em Curitiba-PR e Maia (2004) em Goiânia-GO. Estes estudos ostentam a eficácia do método e avançam cada vez para novos conhecimentos capazes de ajudar na interface homem/meio ambiente. 


\section{CAPÍTULO 3}

ASPECTOS FISIOGRÁFICOS

\subsection{Localização da Área de Estudo - Rio das Antas, Anápolis - GO}

Em Anápolis-GO, a delimitação de suas macrozonas foi realizada através das microbacias hidrográficas considerando os divisores de água da região, exceto a macrozona urbana onde o limite é o perímetro da cidade. O município anapolino localiza-se no centro-sul do Estado de Goiás na denominada zona fisiográfica do Mato Grosso Goiano, cujas coordenadas são 16¹9’39” S e 48 57'10” W. Possui altitude média de 1.017 metros acima do nível do mar (CASTRO, 2004) e encontra-se geograficamente situada entre duas capitais, a $150 \mathrm{~km}$ de Brasília e a $50 \mathrm{~km}$ de Goiânia se tornando um dos principais entroncamentos rodoviários do país pelas BRs 153/060.

A localização privilegiada fez de Anápolis o principal centro de comercialização de grãos do Estado, bem como um dos maiores fornecedores de produtos hortifrutigranjeiros para a Central de Abastecimentos de Goiás-Ceasa (JUNIOR et al., 2010). A instalação da Base Aérea, implantação da Plataforma Logística Multimodal e o crescimento do setor industrial são fatores que constituem subsídios significativos para o crescimento de cidade (CASTRO, 2009). Sua área de 918,38 $\mathrm{km}^{2}$ tinha em 2010, segundo estimativa do IBGE (2010), uma população de 335.032 habitantes, classificada como predominantemente urbana (Tabela 1).

Tabela 1 - Município de Anápolis: Evolução da População no período de 1991 - 2010.

\begin{tabular}{ccccccccc}
\hline & 1991 & & \multicolumn{3}{c}{2000} & & \multicolumn{2}{c}{2010} \\
\hline Total & Urbana & Rural & Total & Urbana & Rural & Total & Urbana & Rural \\
239.378 & 226.925 & 12.453 & 288.085 & 280.164 & 7.921 & 335.032 & 329.170 & 5.862 \\
\hline
\end{tabular}

Fonte: IBGE, Censo 2010.

A microbacia do Rio das Antas possui a maior representatividade real do município e área contendo quase $17 \mathrm{~km}^{2}$ (FERREIRA, 2009). O Rio das Antas é um afluente pela margem direita do rio Corumbá que deságua no rio Paranaíba tributário do rio Paraná, se tornando, portanto integrante do maior corredor hidrográfico do Brasil. Nesse estudo, será considerando como parte da pesquisa apenas o rio que perpassa o perímetro urbano de Anápolis e alguns 
pontos situados à jusante, contemplando uma extensão de aproximadamente $29 \mathrm{~km}$, declividade média de $0,51 \%$ e nascentes ao sul da cidade (Figura 1).

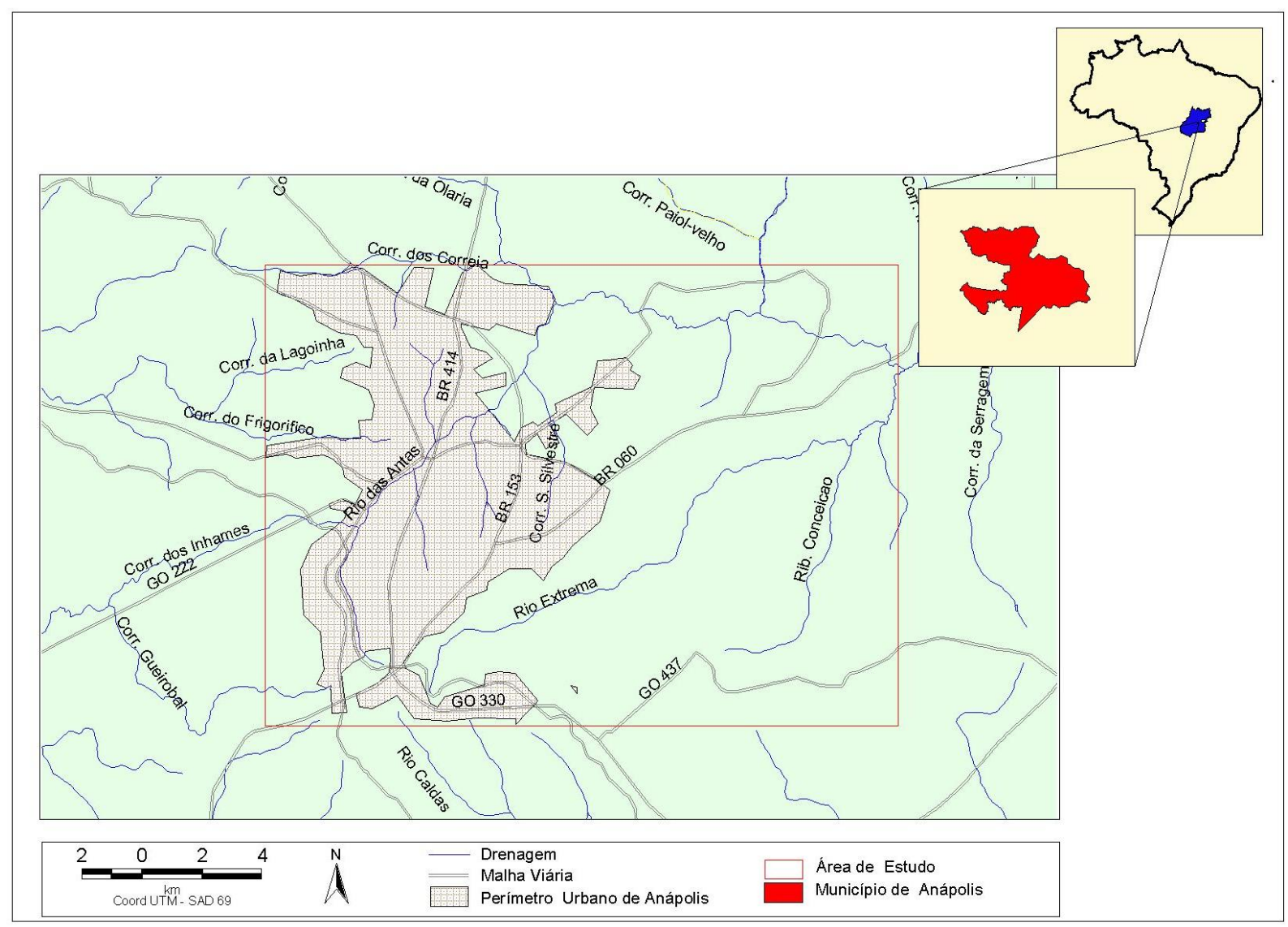

Figura 1 - Localização da Área de Estudo.

A largura transversal do Rio das Antas varia de $2 \mathrm{~m}$ a $10 \mathrm{~m}$ e a profundidade média oscila entre $0,30 \mathrm{~m}$ a $1,10 \mathrm{~m}$. Em sua trajetória, recebe águas de importantes tributários, dentre eles os córregos Góis, Cesários, Água Fria, Ipiranga, Felizardos e Reboleiras (CORRÊA, 2005). Alguns desses tributários são diluidores de elevadas cargas de poluição, como o Córrego dos Cesários, receptor de $1.200 \mathrm{~m}^{3}$ diários de efluentes provenientes da lavagem de filtros da Estação de Tratamento de Água (ETA) lançados no ribeirão sem nenhum tipo de tratamento (OLIVEIRA; BARCELLO; COLARES, 2013).

\subsection{Geologia}

A área do Rio das Antas está inserida no Maciço Mediano de Goiás entre o cráton do São Francisco a leste e o cráton Amazônico a oeste. Geologicamente é descrita segundo os 
dados de Radaelli (1994) na folha Anápolis SE.22-X-B-11, (escala 1:50.000) a qual integra o programa de levantamentos geológicos básicos do Brasil (PLGB). Anápolis situa-se em uma região de zonas de cisalhamento dúcteis transcorrentes e falhas de rumo essencialmente rúptil em direções NW, variações em EW ou ENE. Esse incidente influencia no deflúvio do Rio das Antas a partir do seu médio curso fazendo com que águas percorram encaixadas na falha, determinando a assimetria da bacia (JESUS, 2013).

A região de Anápolis é formada por um solo rico em ocorrências minerais de argila, água potável e manganês. Outros recursos minerais como o granito e a $\mathrm{FeTiO}_{3}$ (ilmenita) também fazem parte da sua composição pedológica. A estratigrafia da área é composta por unidades litológicas do Complexo Granulítico Anápolis-Itauçú, Grupo Araxá Sul de Goiás, Associação Ortognaisse Migmatitica, Formação Silvânia, Cobertura Detrito-lateríticas e Depósitos Aluvionares. O grupo Araxá Sul de Goiás está subdividido em duas unidades: unidade A e unidade B, cuja área de estudo se encontra na unidade B em um trecho restrito na porção oeste (Figura 2).

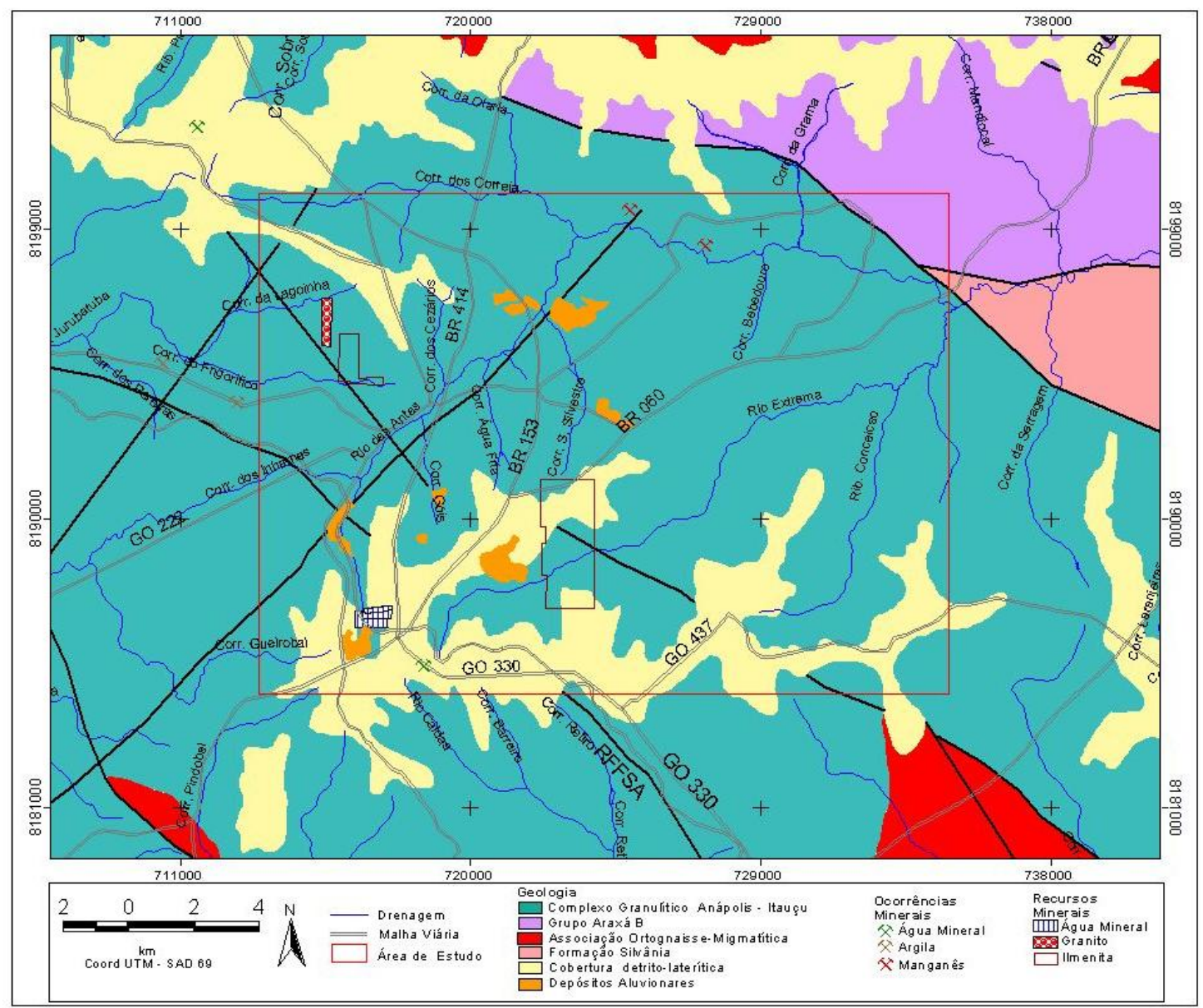

Figura 2 - Mapa Geológico da área do Rio das Antas (SIEG, 2013) 


\subsubsection{Complexo Granulítico Anápolis-Itauçu}

Este complexo trata-se de uma intrincada associação de granulitos e gnaisses derivados de rochas ígneas e sedimentares desenvolvida durante o arqueano proterozóico inferior. É formado por granulitos ortoderivados como metagabróides, metabásicas, enderbitos, charnoenderbitos, charnockitos e metapiroxenitos. A estes, intercalam-se os paraderivados: granada gnaisses, biotita-granada gnaisses, biotita-sillimanita-granada gnaisses, cianitagranada gnaisses, granada quartzitos, gonditos e calcissilicáticas (RIBEIRO, 2008). Os granulitos ortoderivados na região de Anápolis são formados por rochas de origem vulcânica apresentando granulação fina constituídas por epidoto, clorita, sericita, tremolita e carbonato (Radaelli, 1994), enquanto que os paraderivados são essencialmente félsicas provenientes de rochas sedimentares.

Apesar de não estarem registrados no mapa geológico, os paragranulitos foram encontrados em perfis de solo do horizonte $\mathrm{C}$, expostos em taludes, durante trabalhos de campo realizados por Jesus (2007) na bacia do Rio das Antas. Apresenta também saprólito com características coloração róseo-esbranquiçada, indícios de rocha alterada e estrutura de minerais conservados. Outro material de origem secundário (argila branca) foi produzido pelos agentes intempéricos a partir dos feldspatos. (JESUS, 2007).

\subsubsection{Grupo Araxá Sul de Goiás}

Navarro, Zanardo e Conceição (2013) destacam alguns aspectos da evolução geológica do grupo Araxá no Estado de Goiás como os xistos (tectonicamente acima e abaixo do Complexo Anápolis-Itauçu) e Associação Ortognáissica Migmatítica. Conforme os autores, na porção sul, ocorrem sequências metavulcanossedimentares associadas aos metassedimentos do grupo e grande quantidade de corpos intrusivos graníticos. Na base superior, aflora parte da sequência metavulcanossedimentar e a quantidade de corpos graníticos é inferior com destaque para os granitoides.

O Grupo Araxá na porção sul de Goiás inclui um conjunto de metassedimentos onde predominam micaxistos alternados com camadas quartzíticas. A primeira unidade, "A" é formada por xistos com duas micas, finos a grosseiros e com granada, estaurolita, turmalina, rutilo, cianita, cordierita e intercalações de quartzitos, por vezes ferríferos, micáceos finos a 
grosseiros e anfibolitos. A segunda, "B" constitui-se por calcixistos com intercalações de calcários geralmente pouco espessos (RIBEIRO, 2008). Cerca de $80 \%$ das ocorrências do Grupo Araxá B na Folha Anápolis se dá em meio aos granulitos dominantes com predominância de gnaisses (JESUS, 2007).

\subsubsection{Associação Ortognaisse Migmatítica}

A formação Ortognáissica-Migmatítica provavelmente data da idade arqueana a proterozóica. Constituída por granitóides de filiação calcialcalina e baixo potássio, origina da transposição de foliação e lineação mineral de granulitos composta por ortognaisses tonalíticos, granodioríticos e graníticos, às vezes migmatíticos. "Associam-se-lhes encraves de granulitos, o que possibilita supor que derivaram de anatexia, parcial ou total, de rochas do Complexo Granulítico Anápolis-Itauçu” (IBGE FOLHA SE.22-X-B, GOIÂNIA, 1980).

\subsubsection{Formação Silvânia}

Na Formação Silvânia existe rochas de filiação vulcânica, sob a denominação de Complexo Metamórfico Vulcano-Sedimentar. Nesta mesma área prevalecem ocorrências de vulcano-clásticas intercaladas na forma de lentes entre os metassedimentos resultantes de ações tectônicas em regime de cisalhamento dúctil. Nas porções centro-norte e noroeste da formação situa intercalações de biotita, muscovita, quartzo e xisto com lentes de epidoto anfibolito. Nos litótipos das sequencias geológicas onde situa a região de Anápolis ocorrem frequentes intercalações de cianita, clorita, muscovita, biotita xistos e granada anfibolitos, com presença de veios de quartzo e de feldspato cortando o anfibolito (IBGE FOLHA SE.22X-B, GOIÂNIA, 1980).

\subsubsection{Cobertura Detrítico-Laterítica}

São solos pertencentes aos períodos terciário/quaternário que se desenvolveram em unidades geológicas pré-cambrianas, ocorrendo preferencialmente nas superfícies planas dos topos e vertentes superiores dos interflúvios, em altitudes por volta de $1000 \mathrm{~m}$ (JESUS, 2013). Possui espessura superior a 10m, aparência avermelhada constituídos por sedimentos 
conglomeráticos, argilosos parcial e/ou totalmente ferruginizados, areno-argilosos e parcialmente laterizadas (RIBEIRO, 2008). Esta unidade autóctone encontra-se extensamente distribuída na Folha Anápolis sob a forma de crostas ferruginosas mais ou menos degradadas, geralmente recobrindo as superfícies tabulares de cimeira. As coberturas detrito-lateríticas se manifestam no modelado de aplanamento do curso do Rio das Antas bordejando-o a leste, oeste e sul.

\subsubsection{Depósitos Aluvionares}

Cobertura quaternária representada por sedimentos arenosos de granulação média a fina, síltico-argilosos e cascalho. As areias são predominantemente formadas por grãos de quartzo contendo minerais pesados como a magnetita e ilmenita. Os depósitos aluvionares encontram restritos principalmente às calhas das drenagens de porte médio adjacentes ao perímetro urbano onde se retira areia para a construção civil. As planícies fluviais do Rio das Antas, recobertas por depósitos aluvionares, apresentam larguras que variam entre 50 e 200 metros (LACERDA, 2005). Em algumas calhas de outros rios da Folha Anápolis encontra-se níveis de cascalhamento e pequenas turfeiras associadas (RADAELLI, 1994).

\subsection{Geomorfologia}

\subsubsection{Geomorfologia Regional de Anápolis - GO}

Anápolis-GO situa-se na parte do planalto central brasileiro onde se localiza a subunidade do Planalto do Alto Tocantins-Paranaíba (JESUS, 2007). Pode ser subdividido em diferentes tipos, com características peculiares, sobretudo ao que diz respeito à forma, ao espaçamento interfluvial e à potencialidade erosiva. Faz parte de domínio dos chapadões recobertos por cerrados e penetrados por matas de galerias. Seu relevo ondulado apresenta formas convexas associadas a formas tabulares amplas.

Os topos planos ocorrem em altitudes de 1.080 a 1.120 metros e formam os divisores das bacias hidrográficas dos principais cursos d'água da área originando várias nascentes (CORRÊA, 2005). São caracterizados pela presença da cobertura detrito-laterítica, tem gradientes inferiores a $2 \%$ e drenagem superficial ausente. A partir dos topos planos, em 
direção às drenagens principais, incidem rampas retilíneas com declividades da ordem de $2 \%$ a $4 \%$ ao longo dos interflúvios maiores e $4 \%$ a $8 \%$ nos perfis transversais. As rampas aparecem a altitudes de $1000 \mathrm{~m}$ a $1080 \mathrm{~m}$ e são pouco suscetíveis a processos erosivos por apresentar baixa declividade (LACERDA et al., 2005). As cabeceiras das drenagens ao contrário das rampas, bastante susceptíveis a erosões aceleradas, comportam um relevo caracterizado pela maior declividade das vertentes, geralmente entre $8 \%$ a $20 \%$ e, localmente, superior a 30\% chegando em alguns casos, a 50\% (LACERDA et al., 2005). No obstante, a maior parte do território do município possui um relevo medianamente dissecado por erosões causadas pelas águas das chuvas e dos rios, com potencialidade erosiva fraca e poucas dissecações de potencial erosivo forte (Figura 3).

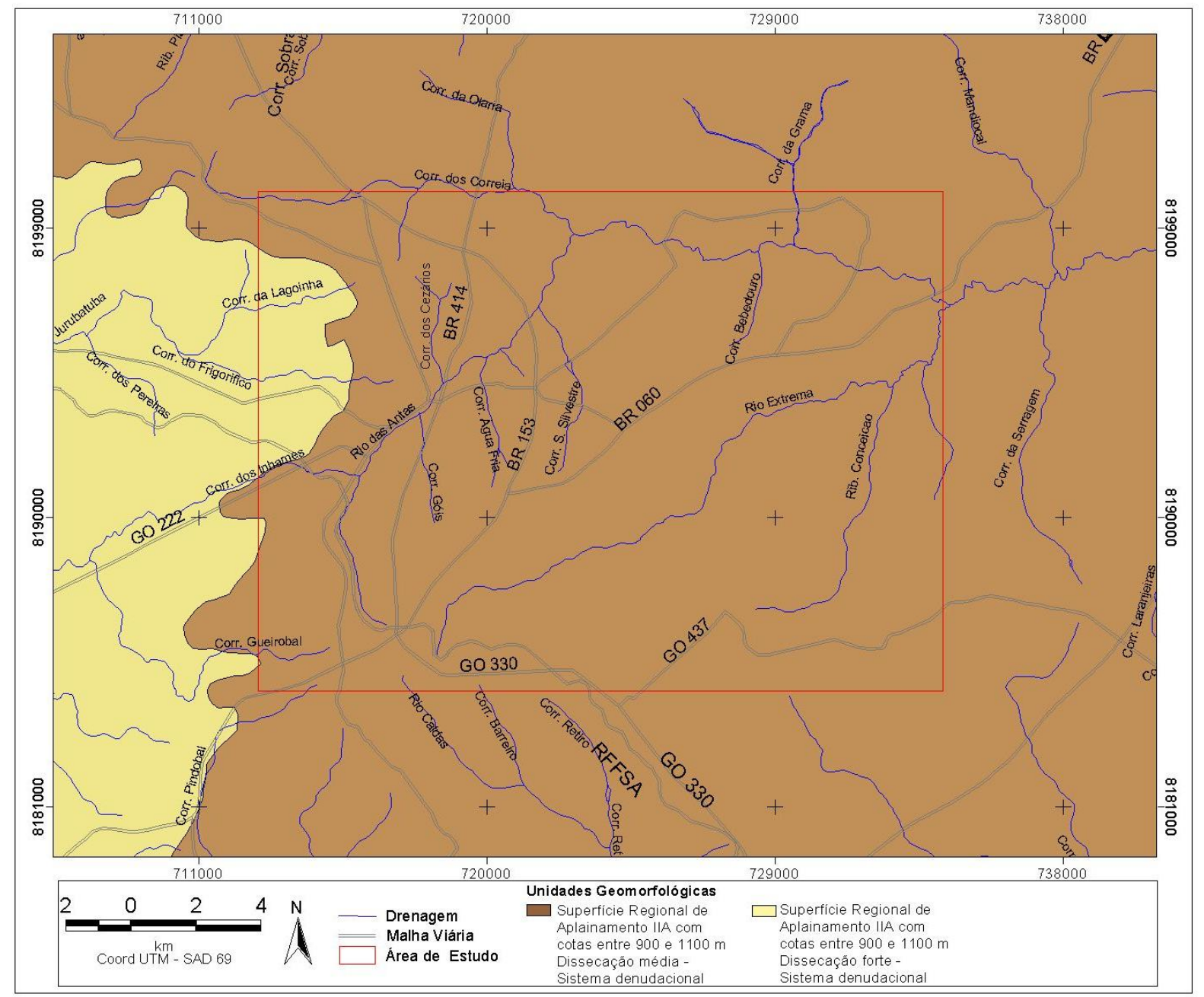

Figura 3 - Mapa Geomorfológico da área do Rio das Antas (SIEG, 2013) 


\subsubsection{Geomorfologia Local: Rio das Antas, Perímetro Urbano de Anápolis - GO}

Lacerda et al. (2005) e Jesus (2013) delineiam a cartografia do relevo da microbacia urbana de Anápolis como Modelados de Aplanamento, Dissecação e Acumulação seguindo conceitos já definidos por Ross (2000).

\section{* $\quad$ Modelado de Aplanamento}

Compreende formas tabulares localizadas em altitudes acima de $1100 \mathrm{~m}$, conectados a rampas com baixas declividades. Morfologicamente este compartimento contém interflúvios maiores a sul $(1.115 \mathrm{~m}$ e $1.151 \mathrm{~m})$, leste $(1.130 \mathrm{~m})$ e oeste $(1.110 \mathrm{~m}$ e $1.125 \mathrm{~m})$ sendo pouco aptas à erosão devido às declividades quase nulas. Nesses locais, geralmente as rampas abrangem de $2 \mathrm{~km}$ a $4 \mathrm{~km}$ e perfis retilíneos. Com um pouco mais de declividade (4\% a 8\%) e rampas de $700 \mathrm{~m}$, se encontram os perfis transversais caracterizados como ligeiramente convexos. No curso do rio, ao longo dos limites entre rampas e topos existe um rebordo erosivo a oeste da bacia representado por um segmento de vertente com declividades da ordem de $10 \%$ a $20 \%$. As altitudes vão decrescendo em direção ao norte evidenciando topos planos com altitudes inferiores a $1000 \mathrm{~m}$ e planícies com declividades inferiores a $5 \%$ cujas vertentes variam de $5 \%$ a maior de $30 \%$.

\section{* Modelado de Dissecação}

A passagem do modelado de Aplanamento para o de Dissecação ocorre por uma fração retilínea que conecta o topo plano de ambas as margens a segmentos suavemente convexos. Na parte oeste do Rio das Antas há uma associação de morros e esporões que se projetam das áreas mais elevadas em direção às mais baixas. Este modelado possui muitas cabeceiras de drenagem, altitudes entre $1000 \mathrm{~m}$ e $1100 \mathrm{~m}$ e declividades relativamente elevadas, o que favorece a susceptibilidade a erosões.

Os comprimentos das encostas são da ordem de $200 \mathrm{~m}$ a $500 \mathrm{~m}$ e dependendo da posição no modelado, as vertentes adquirem formas variadas de declividades de $5 \%$ a $10 \%$ naquelas de trecho superior e $10 \%$ a maior de $25 \%$ nas médias vertentes, através de rupturas de declive. As ocupações por habitação nesses locais são inadequadas principalmente porque os 
traçados das ruas ao longo das declividades, com carências de sistemas de drenagens ou inexistências deles, propicia um grande número de erosões em sulcos, ravinas e voçorocas ou alagamentos pela água do escoamento superficial.

Nas baixas vertentes, as declividades de 5\% a 10\% voltam a aparecer. Às margens leste, elas têm comprimento médio de aproximadamente $1.267 \mathrm{~m}$, e a oeste, cerca de $850 \mathrm{~m}$, diferença associada em função da assimetria da bacia. Diversas vezes na margem oeste, as vertentes passam de um modelado para o outro de forma direta. Destacam-se, na região do médio curso da bacia, à margem oeste, vertentes convexas ou retilíneas em perfil e côncavas em planta. As declividades nesse curso geralmente se mostram no intervalo de $8 \%$ a $20 \%$ com desníveis de $40 \mathrm{~m}$ a $80 \mathrm{~m}$.

\section{* Modelado de Acumulação}

Este modelado é formado por processos deposicionais quase sempre nos fundos dos vales e na porção centro-leste da bacia ao longo do Rio das Antas e de alguns afluentes. É assinalada por planícies de inundação com formações do tipo aluvionar compostas de sedimentos arenosos ou areno-argilosos. Localiza-se em altitudes menores que $1000 \mathrm{~m}$ e declividades inferiores a $5 \%$ onde as larguras variam entre $50 \mathrm{~m}$ e $200 \mathrm{~m}$. "O vale fluvial do rio das Antas apresenta fundo em "V" até o médio curso, a partir de onde exibe um fundo côncavo [...] e dá lugar a um vale de fundo chato com conformação próxima de "U" (JESUS, 2007). A carta topográfica não possibilita a distinção de uma planície fluvial segmentada ao longo do rio das Antas, mas Jesus (2007) registrou a presença dessa planície em várias partes do curso do rio, onde há acúmulo de sedimentos. Alguns estavam sob a forma de cone de dejeção por causa do fundo chato.

\subsection{Pedologia}

Anápolis possui formação pedológica composta por couraças lateríticas, colúvios, saprolitos, aluviões, rocha original intemperizada e fraturada. Os solos estão classificados de acordo com a nova nomenclatura da EMBRAPA (2006) em: Associação Latossolo Vermelho não-férrico com Latossolo Vermelho férrico, Latossolo Vermelho não-férrico com Latossolo Vermelho-Amarelo, Plintossolo Pétrico Concrecionário, Latossolo Vermelho-Amarelo e 
Argissolo Vermelho Eutrófico (Figura 4).

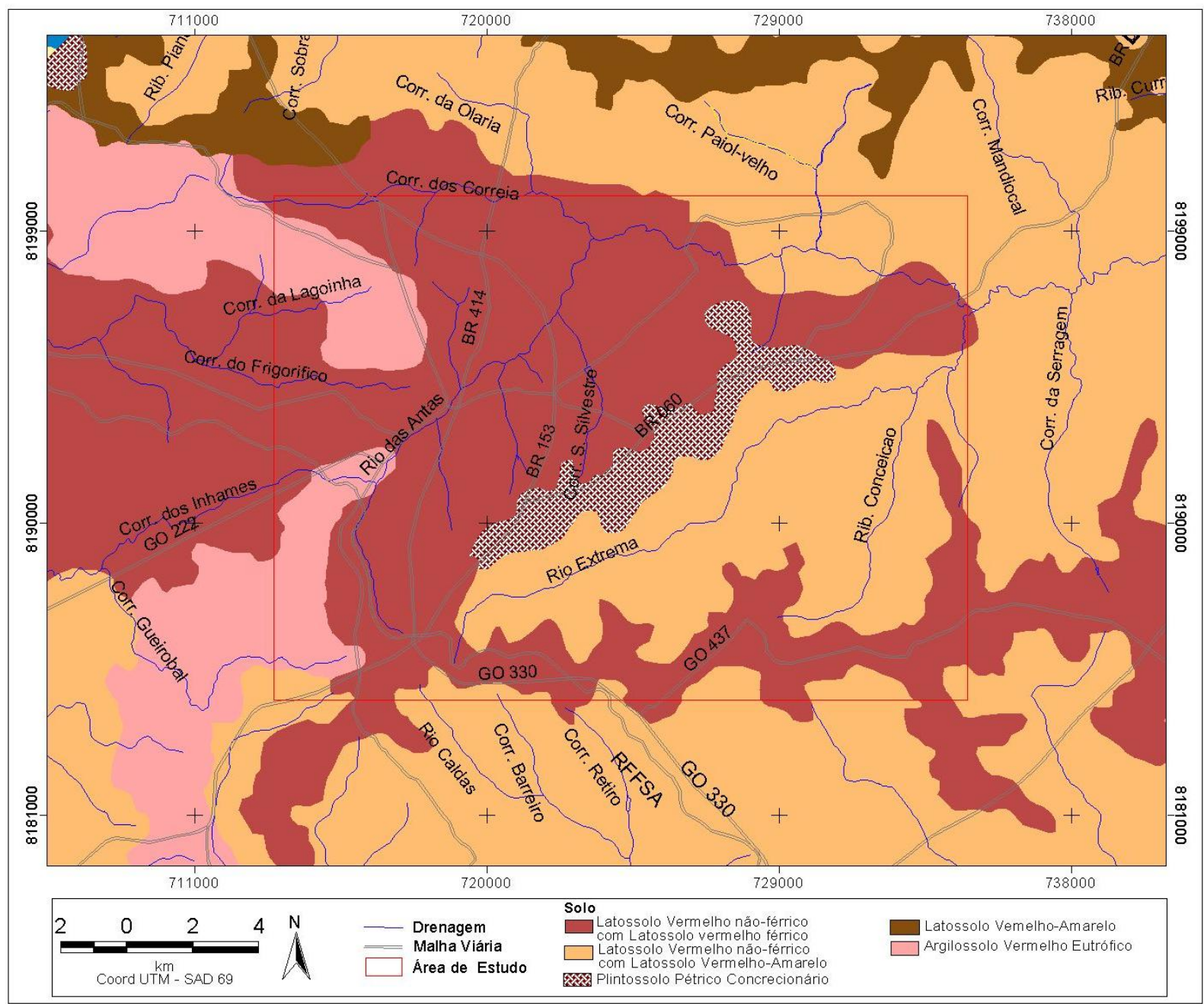

Figura 4 - Mapa de Solo da Área de Estudo (SIEG, 2013).

\section{* Associação Latossolo Vermelho não-férrico com Latossolo Vermelho férrico}

Solos profundos, homogêneos, muito permeáveis, altamente intemperizados e de textura argilosa (EMBRAPA, 2006). Na área de estudo eles se encontram quase sempre com cobertura laterítica e ocupam os terrenos planos e os relevos suavemente ondulados nas superfícies baixas.

\section{* Latossolo Vermelho não-férrico com Latossolo Vermelho-Amarelo}

Estes solos estão amplamente distribuídos na Folha Anápolis em locais planos no alto 
dos morros e em terrenos suavemente ondulados nas baixas altitudes. Apresentam nódulos e concreções avermelhadas, são menos profundos que os Latossolos Vermelhos e mais úmidos. Apesar de bastante ácidos, pobres em nutrientes e com pouca fixação de fósforo, quando adubados se tornam produtivos.

\section{* Plintossolo Pétrico Concrecionário}

Apresentam horizonte litoplíntico, contínuo ou semicontínuo, com mais de $10 \mathrm{~cm}$ de espessura ou 50\% de petroplíntita a $40 \mathrm{~cm}$ da superfície do solo (JESUS, 2013). Podem também surgir imediatamente após o horizonte A ou E com coloração mosqueado vermelhoamareladas e pálido acinzentado, branco ou amarelo claro, com espessura de $2 \mathrm{~m}$, contendo manchas decimétricas marrons. Jesus (2007) encontrou plintossolos no horizonte C, expostos em perfis de solo na bacia do Rio das Antas sobre remanescentes de superfície de erosão. A espessura total observada é da ordem de $7 \mathrm{~m}$, numa seção composta, elaborada a partir de exposições descontínuas. Imediatamente acima do horizonte $\mathrm{C}$ aparece uma zona de pequenos nódulos de óxidos e hidróxidos em matriz amarelada sobreposta a um horizonte petroplíntico coberto por cascalho ou sedimento arenoso similar à da zona subjacente decorrente da degradação da mesma.

Relevos planos ou suavemente ondulados, áreas de várzea e outras sujeitas à oscilação freática apresentam a formação de Plintossolos Pétricos sobre o Modelado de Aplanamento e sua gênese está associada a alternâncias pretéritas de períodos secos e úmidos. Aparece também em rampas de altitudes de $1.040 \mathrm{~m}$ a $1.100 \mathrm{~m}$, na região sul e norte da área, grande parte das formações superficiais que tem o saprolito na sua base, recobertos por uma camada de cascalho laterítico, de espessura entre $1 \mathrm{~m}$ a $2 \mathrm{~m}$. Tal cascalho é proveniente da degradação do regolito laterítico composto por clastos centimétricos-decimétricos de concreções lateríticas com pouca matriz arenosa.

\section{* Latossolo Vermelho-Amarelo}

Texturas muito argilosas ocorrem em relevo plano e frequentemente concrecionário. $\mathrm{Na}$ área de pesquisa, possuem horizonte $\mathrm{B}$ menos espesso que os Latossolos Vermelhos, isso porque, as declividades das vertentes são maiores fazendo com que a pedogênese seja 
atenuada pelos processos morfogenéticos não permitindo seu maior aprofundamento. Os Latossolos Vermelho-Amarelo são distróficos, recobrem residuais de superfícies de aplanamento e outras paisagens com perfis de topo na porção sul e norte da bacia. "Quanto ao caráter distrófico, refere-se à baixa saturação por bases” (JESUS, 2007). No Rio das Antas, eles correspondem ao modelado de dissecação nos primeiros $100 \mathrm{~cm}$ do horizonte $\mathrm{B}$, mas apresentam-se também nos horizontes A com altura de $10 \mathrm{~cm}$ sobreposto ao horizonte B de espessuras superiores a 1,5m tornando-se mais perceptíveis na vertente inferior devido à contribuição coluvionar. Nas vertentes médias, o horizonte $C$ com aproximadamente $9 \mathrm{~m}$ permite visualizar no talude da voçoroca um manto intempérico branco-rosáseo refletindo fielmente a orientação dos minerais da rocha matriz (JESUS, 2007).

Nas baixas vertentes existem saprolitos com até 10m de espessura originada de rocha metamórfica e estruturas reliquiares como fraturas e bandamento constituído por argilominerais, quartzo e mica formado de diferentes óxidos de ferro. Na parte superior do saprolito observa-se uma formação de veios de quartzo in situ. Os clastos, predominantemente constituídos por quartzo recobrem o saprolito por um horizonte muito pequeno de cascalho marrom e acima se obtém um horizonte areno-argiloso de espessura métrica e cor marrom amarelada.

\section{* Argissolo Vermelho Eutrófico}

São mais férteis que os outros solos do Cerrado, possuem textura média/argilosa e se desenvolve em relevo ondulado. Quanto à textura, os Argissolos revelaram diferenças nos percentuais de argila e areia no curso do Rio das Antas analisada por Jesus (2007). O horizonte Bt pode ser classificado em argiloso e o horizonte C, arenoso (Tabela 2). Jesus (2007) afere essa diferença de horizontes a processos de estágio de pedogênese e à influência do material de origem (rocha). Destaca que, a ocorrência da maior erodibilidade do solo no horizonte $\mathrm{C}$ se caracteriza por causa dos altos teores de areia as quais confirmam o caráter ácido e félsico da rocha alterada com a estrutura conservada. 
Tabela 2 - Granulometria em \% no Alto Curso do Rio das Antas

\begin{tabular}{ccccc}
\hline Horizonte & Areia Grossa & Areia Fina & Silte & Argila \\
\hline $\mathrm{Bt}$ & 26 & 16 & 11 & 47 \\
$\mathrm{C}$ & 66 & 18 & 5 & 11 \\
\hline
\end{tabular}

Fonte: Jesus, 2007 (Adaptado)

Apesar de não aparecer no mapa, Jesus (2007) destaca a presença de Gleissolos Melânicos na região do Rio das Antas. Os Gleissolos Melânicos são solos minerais que possuem normalmente uma profundidade de $10 \mathrm{~cm}$ a $50 \mathrm{~cm}$ situados $\log$ abaixo do horizonte A apresentando coloração em tons variados de cinza. Possui menos de $15 \%$ de plintita, são pouco desenvolvidos e de textura constante, quando argilosos possuem consistência plástica e pegajosa. "Estes solos podem ser ricos ou pobres em bases, ou com teores elevados de alumínio e teores variados (médios a altos) de carbono orgânico" (JESUS, 2007). No curso do Rio das Antas, os Gleissolos Melânicos ocorrem nas cabeceiras de drenagem onde há inundações e em áreas de várzea sob terrenos planos. Também aparece em algumas partes, no Modelado de Acumulação ao longo da planície de inundação e em solos onde o encharcamento acontece o ano todo devido à elevação do nível freático.

\subsection{Clima}

O clima da região de acordo com a classificação de Koeppen é do tipo AW, tropical subúmido. A temperatura média anual oscila de $20^{\circ} \mathrm{C}$ a $23^{\circ} \mathrm{C}$ destacando a existência de duas estações bem definidas, uma seca e outra chuvosa. Freitas (1995) afirma que no mês de julho ela pode chegar a $7^{\circ} \mathrm{C}$ e de janeiro a março, atingir $30^{\circ} \mathrm{C}$. A umidade relativa do ar fica em torno de 50\% a 60\%, ultrapassando 80\% nos períodos chuvosos (JESUS, 2013). Segundo Ferreira (2009) na estação seca (abril a setembro) a precipitação permanece abaixo de $10 \mathrm{~mm}$ mensais e supera $250 \mathrm{~mm}$ durante a úmida (outubro a março). Freitas (1995) quantifica a precipitação pluviométrica anual de Anápolis em 1.450mm, no entanto, Jesus (2013) alega a variância dessas precipitações em torno de $1.750 \mathrm{~mm}$ a $2.000 \mathrm{~mm}$, citando dados do Centro Meteorológico Militar da Base Aérea de Anápolis (2005) a qual os registros comprovam precipitações superiores a $2000 \mathrm{~mm}$ durante alguns anos. 


\subsection{Uso e Cobertura do Solo}

Na área do rio das Antas, a vegetação foi bastante alterada com pastagens, remanescentes esparsos de cerrado e pequenos fragmentos de mata onde não há urbanização. Em detrimento da formação dessas pastagens, os remanescentes do cerrado assim como as matas foram dizimadas e as manchas ainda existentes ocupavam, em sua maioria, as áreas mais elevadas da região de Anápolis. Segundo Magnano et al. (1983) apud Jesus (2007), “a bacia do rio das Antas está inserida numa área de tensão ecológica, representada pelo contato entre vegetação de savana e floresta estacional”.

As savanas possuem árvores e arbustos espalhados de formação descontínua englobando Palmeiral, Veredas, Cerrado Denso, Cerrado Ralo e Cerrado Rupestre. Já nas formações florestais prevalecem espécies arbóreas na variação de Mata Ciliar e Mata de Galeria, fisionomias associadas a cursos d'água. A predominância na área de estudo é da Mata de Galeria nas proximidades dos vales fluviais e nas cabeceiras de drenagem. A fitofissionomia savânica predominante se refere ao Cerrado Ralo, um subtipo de vegetação arbóreo-arbustiva de porte médio, medindo de dois a três metros com cobertura de 5\% a 20\% (RIBEIRO; WALTER, 1998). Esses remanescentes estão sob os Plintossolos Pétricos Concrecionários nos topos planos do Modelado de Aplanamento.

Jesus (2013) traçou um perfil para o uso e cobertura do solo abordando a evolução do mesmo no decorrer de 1965 a 2010 e suas respectivas tendências. Seu estudo mostrou variações importantes onde é possível observar redução gradativa das áreas de pastagens, formações savânicas e avanço de regiões antropizadas e agricultura. A vegetação natural foi perdendo espaço nas formações savânicas de maneira bem mais acelerada do que as formações florestais. Jesus (2013) acredita que essa perda está relacionada à formação das fazendas existentes antes da urbanização de Anápolis. A Figura 5 apresenta o mapa de uso e cobertura do solo do município de Anápolis/GO segundo informações da base de dados do Sistema de Informação Geográfica do Estado de Goiás (SIEG, 2013). 


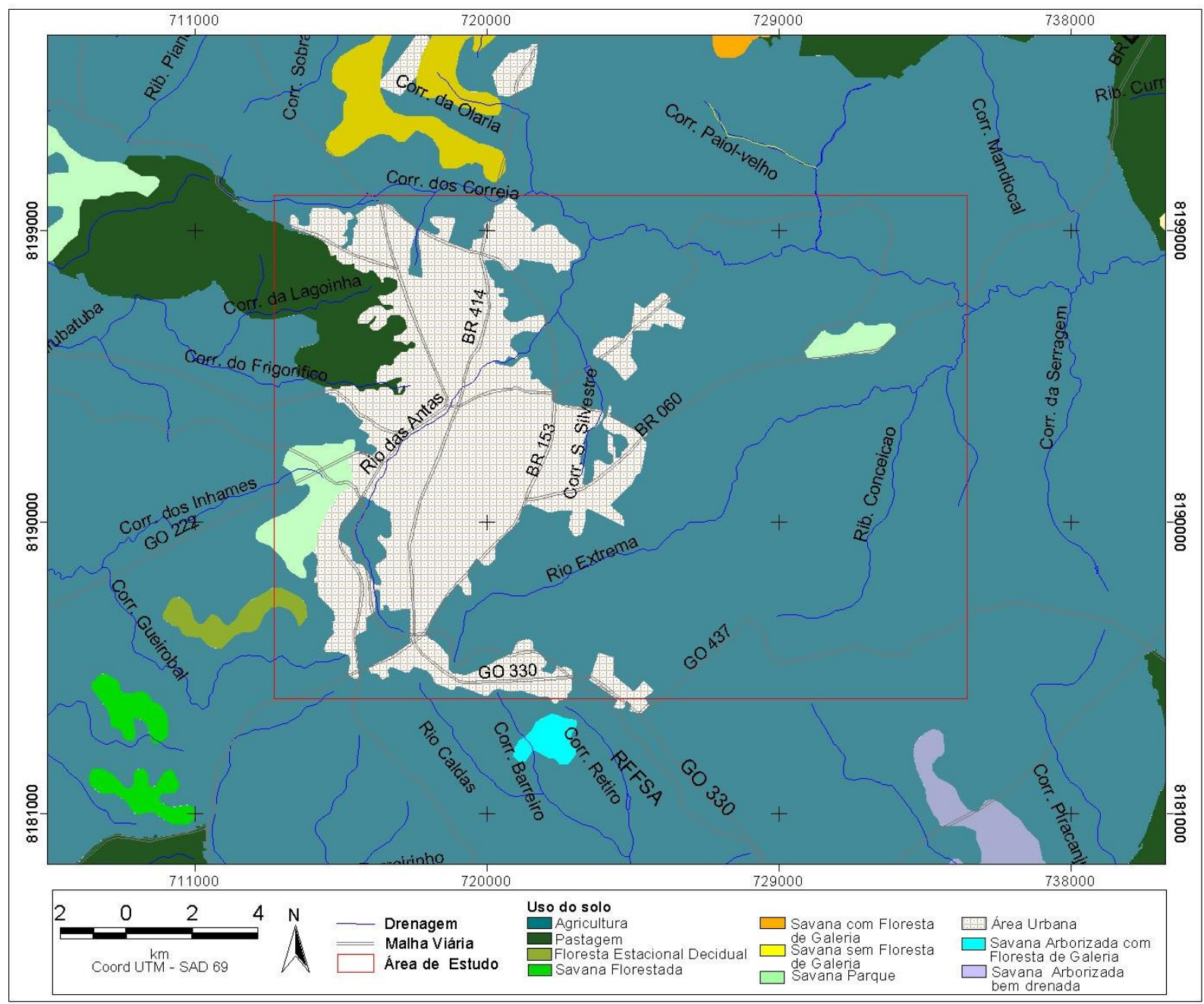

Figura 5 - Mapa de Cobertura do Solo (SIEG, 2013) 
METODOLOGIA

\subsection{Amostragem}

Para a obtenção das amostras de água e sedimento de fundo, dividiu-se a coleta em três etapas distintas, a primeira (água) e a segunda (sedimento de fundo) foram realizadas em 22 pontos distribuídos ao longo do Rio das Antas de acordo com as unidades geológicas e os diversos tipos de uso do solo durante as estações seca (agosto de 2013) e chuvosa (março de 2014). A terceira etapa ocorreu em 10 pontos estrategicamente distribuídos no mês de junho de 2014 de acordo com a possibilidade de influências externas e internas do meio. $\mathrm{Na}$ terceira etapa, coletou-se apenas água para amostragens referentes a análises de microorganismos (coliformes totais e fecais) e complemento de parâmetros que não foram analisados na primeira etapa, como OD e DBO. A Tabela 3 descreve os locais amostrados com suas respectivas coordenadas geográficas e a Figura 6 mostra os pontos de coleta das etapas na área de estudo.

Tabela 3 - Pontos de Coleta de Água e Sedimento de Fundo

\begin{tabular}{|c|c|c|c|c|c|}
\hline \multicolumn{6}{|c|}{ Primeira e Segunda Etapa - Água e Sedimento de Fundo } \\
\hline Ponto & \multicolumn{2}{|c|}{ Coordenadas } & Ponto & \multicolumn{2}{|c|}{ Coordenadas } \\
\hline & $\mathrm{N}$ & $\mathrm{E}$ & & $\mathrm{N}$ & $\mathrm{E}$ \\
\hline 1 & 8186254 & 716295 & 12 & 8194216 & 719581 \\
\hline 2 & 8188995 & 715877 & 13 & 8195184 & 721105 \\
\hline 3 & 8191674 & 715485 & 14 & 8196070 & 721795 \\
\hline 4 & 8192453 & 717515 & 15 & 8196403 & 722216 \\
\hline 5 & 8192472 & 718702 & 16 & 8196310 & 722245 \\
\hline 6 & 8193149 & 718650 & 17 & 8196983 & 722351 \\
\hline 7 & 8193391 & 719008 & 18 & 8197935 & 729098 \\
\hline 8 & 8194328 & 717533 & 19 & 8198503 & 730196 \\
\hline 9 & 8196974 & 719133 & 20 & 8197960 & 729211 \\
\hline 10 & 8194313 & 719018 & 21 & 8197746 & 732000 \\
\hline 11 & 8194978 & 720212 & 22 & 8197453 & 733482 \\
\hline \multicolumn{6}{|c|}{ Terceira Etapa - Água } \\
\hline Ponto & \multicolumn{2}{|c|}{ Coordenadas } & Ponto & \multicolumn{2}{|c|}{ Coordenadas } \\
\hline & $\mathrm{N}$ & $\mathrm{E}$ & & $\mathrm{N}$ & $\mathrm{E}$ \\
\hline 1 & 8186285 & 716266 & 6 & 8198575 & 723218 \\
\hline 2 & 8188837 & 716291 & 7 & 8199085 & 724500 \\
\hline 3 & 8192423 & 717455 & 8 & 8198483 & 726187 \\
\hline 4 & 8194216 & 719551 & 9 & 8197684 & 731999 \\
\hline 5 & 8194972 & 720806 & 10 & 8195950 & 734575 \\
\hline
\end{tabular}




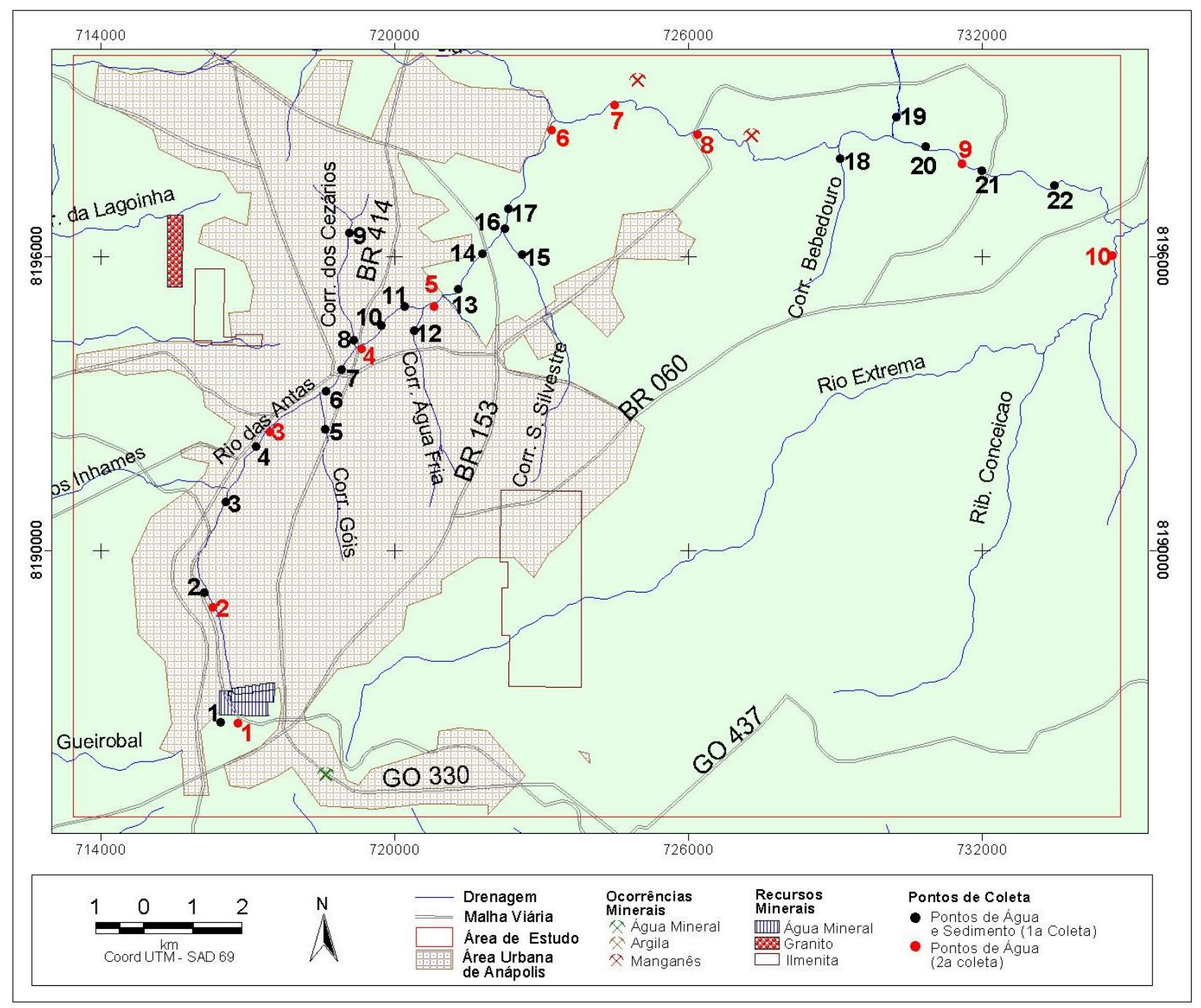

Figura 6 - Localização dos pontos de coleta de Água e Sedimentos de Fundo (primeira e segunda etapa destacadas em preto, terceira etapa em vermelho) (SIEG, 2013 Modificado).

A coleta realizada no ponto P1 (nascente) representa amostra extraída em local de área preservada também considerada Backgroud em valores referência para o trabalho. Os pontos 18 a 22 (primeira e segunda etapa), 7 a 10 (terceira etapa) refletem a qualidade da água após passar pelo perímetro urbano. Mendonça e Marques (2011) indicam esse procedimento para avaliar a influência da área à montante do sistema lótico, pois, durante o curso do rio ainda podem ocorrer várias transformações em suas características devido à capacidade de depuração do ambiente, atuação de microrganismos entre outros.

No trabalho de campo, fez-se uso de mapas hidrogeológicos do município de AnápolisGO, aparelho de GPS e termômetro para aferição da temperatura. Para armazenamento das amostras de água utilizou-se frascos de polietileno de 1L descontaminados com ácido diluído e para sedimentos, sacos de polietileno de $1 \mathrm{~kg}$, todos previamente identificados. As coletas 
de sedimentos de fundo se realizaram em locais de influência ativa, no leito do rio ou próximas às suas margens. Nas coletas de amostras de água destinadas a análises bacteriológicas utilizou-se frascos de vidro, com capacidade de $250 \mathrm{~mL}$, devidamente higienizados e esterilizados em autoclave a $121{ }^{\circ} \mathrm{C}$ por 15 minutos. Os frascos esterilizados possuíam como proteção do gargalo e da tampa um envoltório de papel que foi retirado com cuidado no momento da coleta. Esse procedimento realizou-se de maneira que o gargalo ou a parte interna da tampa não entrasse em contato com as mãos ou com material estranho (terra, por exemplo).

Para os parâmetros OD e DBO, utilizou-se frascos de polietileno de $500 \mathrm{~mL}$ lavados com ácido nítrico $1,59 \mathrm{~mol} \mathrm{~L}^{-1}$ e com água obtida por sistema de purificação MilliQ (resistividade de $18,2 \mathrm{M} \Omega \mathrm{cm}^{-1}$ a $25^{\circ} \mathrm{C}$ ). No momento da coleta, todos os recipientes foram ambientados com a mesma água da amostra coletada e depois acondicionados sob refrigeração em caixas térmicas até a chegada ao laboratório.

\subsection{Análise das Amostras de Água e Sedimentos de Fundo}

\subsubsection{Determinação dos parâmetros físico-químicos}

Ao serem encaminhadas ao laboratório de geoquímica da UnB (LAGEO/UnB), as amostras foram divididas em duas frações e filtradas para frascos de centrífuga de $50 \mathrm{~mL}$ utilizando membranas HA em ésteres de celulose, Millipore, estéril, com 0,45 $\mu \mathrm{m}$ de poro. Uma das frações foi acidificada com ácido nítrico suprapur® Merck $1,59 \mathrm{~mol} \mathrm{~L}^{-1}$ até $\mathrm{pH}<2$ para determinação de metais e a outra reservada para análise dos ânions, ambas refrigeradas a $4{ }^{\circ} \mathrm{C}$. O pH, a condutividade elétrica e o TDS foram determinados no trabalho de campo utilizando um multiparâmetro portátil da marca Hach, série Sension, previamente calibrados com as respectivas soluções padrões. A temperatura aferida em campo realizou-se com o auxílio de um termômetro químico calibrado (Incoterm) e filamento de mercúrio graduado em décimos até $100{ }^{\circ} \mathrm{C}$.

A determinação da turbidez e $\mathrm{NH}_{3}$ foram feitas através de técnicas de espectrofotometria UV/Visível com leitura direta em equipamento Hach modelo DR 2000 a $425 \mathrm{~nm}$. Mediu-se o íon amônio $\left(\mathrm{NH}_{4}{ }^{+}\right)$pelo método colorimétrico utilizando kits de reação para amônia (Mineral Stabilizer, Alcool polivinílico e reagente de Nessler). A determinação 
do $\mathrm{CO}_{2}$ livre se deu por titulação com $\mathrm{Na}_{2} \mathrm{CO}_{3} \quad 0,02$ mol L $\mathrm{L}^{-1}$ até $\mathrm{pH} 8,3$ e indicador fenolftaleína, empregando o seguinte cálculo: $\mathrm{CO}_{2}\left(\mathrm{mg} \mathrm{L}^{-1}\right)=\mathrm{V}_{\text {titulado }} \mathrm{x} 0,04 \times 22000 \times \mathrm{x}_{\text {amostra }}{ }^{-1}$.

As determinações de OD e DBO foram realizadas no laboratório da SANEAGO/SA. Usou-se o método idométrico para determinação de OD que consistiu em encher lentamente um frasco de Winkler com amostra de água bruta (evitando formação de bolhas). Adicionou na amostra, $2 \mathrm{~mL}$ de solução sulfato manganoso com a ponta da pipeta mergulhada no interior do líquido e colocando em seguida $2 \mathrm{~mL}$ de solução álcali-iodeto. Tampou-se o frasco, agitando-o por inversões sucessivas, num intervalo correspondente a 3 minutos para a decantação do precipitado (na solução de sulfato manganoso em meio alcalino ocorre a fixação do oxigênio dissolvido). Acrescentou-se $2 \mathrm{~mL}$ de ácido sulfúrico concentrado, fechou o frasco e repetiu o procedimento de agitação descrito anteriormente (na adição de solução ácida ocorre a formação de íons). Em seguida, $200 \mathrm{~mL}$ da amostras foram titulados com tiossulfato de sódio 0,01 mol L-1 $\left(\mathrm{Na}_{2} \mathrm{~S}_{2} \mathrm{O}_{3}\right)$ até o aparecimento de coloração amarelo-palha. Adicionou-se 5 gotas de amido, prosseguindo a titulação até o desaparecimento da cor azul. O volume de tiossulfato de sódio utilizado na titulação é o valor de OD expresso em $\mathrm{mg} \mathrm{L}^{-1}$ $\mathrm{O}_{2}$ (APHA, 2005).

Para a determinação da DBO estipulou-se o consumo de oxigênio necessário para decompor a matéria orgânica biologicamente degradável em um período de 5 dias à temperatura de $20^{\circ} \mathrm{C}$. A princípio, determinou-se o oxigênio dissolvido inicial (ODI). Para o oxigênio dissolvido final (ODF) incubou-se o frasco de Winkler com amostra de água bruta a $20{ }^{\circ} \mathrm{C} \pm 0,5{ }^{\circ} \mathrm{C}$ durante 5 dias (APHA, 2005). $\mathrm{O}$ valor de DBO é expresso em $\mathrm{mg} \mathrm{L}^{-1} \mathrm{O}_{2}$ obtido pela seguinte fórmula:

\section{$\mathrm{DBO}=\underline{(\mathrm{ODI}-\mathrm{ODF}) \times 100}$ \\ $\mathrm{V}$}

Onde:

ODI=oxigênio dissolvido inicial $\left(\mathrm{mg} \mathrm{L}^{-1}\right)$;

$\mathrm{ODF}=$ oxigênio dissolvido final $\left(\mathrm{mg} \mathrm{L}^{-1}\right)$

$\mathrm{V}=$ volume da fração decimal da amostra utilizada (L) 


\subsubsection{Determinação dos Ânions}

Os ânions $\mathrm{F}^{-}, \mathrm{Cl}^{-}, \mathrm{NO}_{3}{ }^{-}, \mathrm{PO}_{4}{ }^{3-} \mathrm{e} \mathrm{SO}_{4}{ }^{2-}$ foram determinados no (LAGEO/UnB), por meio do cromatógrafo iônico (IC) da marca Dionex, modelo Ion Chromatography System (ICS90). Características do sistema utilizado:

- fluxo isocrático de eluente $\mathrm{Na}_{2} \mathrm{CO}_{3}: \mathrm{NaHCO}_{3} \quad 3,5: 1 \mathrm{mM}$ a $1,2 \mathrm{~mL} \mathrm{~min}^{-1}$ e pressão aproximada de 1500 psi;

- $\quad$ volume de injeção de $25 \mu \mathrm{L}$ definido por alça de amostragem;

- $\quad$ detector de condutividade suprimida modelo CS5;

- coluna e pré-coluna do tipo troca iônica com superfície funcionalizada de alquil amônio quaternário, modelos AS14A e AG14A, respectivamente;

- $\quad$ supressor de condutividade modelo AMMS-300 regenerado com $\mathrm{H}_{2} \mathrm{SO}_{4} 50$ mol L-1.

A alcalinidade foi determinada por método titulométrico de análise com $\mathrm{H}^{2} \mathrm{SO}^{4} 0,01$ mol L $\mathrm{L}^{-1}$ padronizado com $\mathrm{NaOH} 0,05 \mathrm{~mol} \mathrm{~L}^{-1}$, utilizando um titulador automático da marca Schott, modelo Titroline easy através do cálculo:

$$
\mathrm{HCO}_{3}{ }^{-}\left(\mathrm{mg} \mathrm{L}^{-1}\right)=\mathrm{V}_{\text {ácido }} \mathrm{X} \mathrm{M}_{\text {ácido }} \mathrm{x} 61000 \times \mathrm{XV}_{\text {amostra }}{ }^{-1} \text {. }
$$

\subsubsection{Determinação dos Metais}

Determinou-se o elemento $\mathrm{Na}(589,00 \mathrm{~nm})$ e $\mathrm{K}(766,49 \mathrm{~nm})$ em sedimento de fundo por Espectrofometria de Absorção Atômica (EAA) em espectrofotômetro, marca Perkin Elmer, modelo Analyst 200 e fonte de excitação chama de ar-acetileno na proporção de 10: 2,5 $\mathrm{L} \mathrm{min}^{-1}$. A fenda utilizada foi de $1,8 \mathrm{~mm}$ de altura $\times 0,6 \mathrm{~mm}$ de largura ( As análises das amostras para determinar os elementos maiores e traço foram realizadas no Espectrômetro de Emissão Atômica com Plasma indutivamente acoplado (ICP/OES), marca Spectro Analitycal Instruments GmbH e modelo Spectroflame-FVMO3 com nebulizador Meinhard. O plasma foi mantido pelo gás argônio qualidade industrial a um fluxo principal de $1 \mathrm{~L} \mathrm{~min}^{-1}$, fluxo auxiliar de $0,6 \mathrm{~L} \mathrm{~min}^{-1}$ e fluxo para resfriamento de $13 \mathrm{~L} \mathrm{~min}^{-1}$. As linhas espectrais para o comprimento das ondas em função da maior sensibilidade de cada elemento estão expressas na Tabela 4. 
Tabela 4 - Comprimento de onda dos elementos utilizado no ICP/OES

\begin{tabular}{cc}
\hline Elemento & Linha Analítica (nm) \\
\hline $\mathrm{Al}$ & 308,21 \\
$\mathrm{Fe}$ & 259,95 \\
$\mathrm{Si}$ & 251,61 \\
$\mathrm{Ca}$ & 317,93 \\
$\mathrm{Mg}$ & 279,88 \\
$\mathrm{Ti}$ & 334,94 \\
$\mathrm{Sr}$ & 407,77 \\
$\mathrm{Ni}$ & 231.60 \\
$\mathrm{~V}$ & 311,07 \\
$\mathrm{Cu}$ & 324,75 \\
$\mathrm{Cr}$ & 267,72 \\
$\mathrm{Mn}$ & 257,61 \\
$\mathrm{Ba}$ & 233,53 \\
$\mathrm{Zn}$ & 213,86 \\
$\mathrm{Co}$ & 228,62 \\
\hline
\end{tabular}

\subsubsection{Preparação das amostras de Sedimento}

Para as análises de amostras de sedimento de fundo utilizou-se a metodologia padrão do LAGEO/UnB delimitadas para estudos ambientais desenvolvidas através de complementações do trabalho de Boaventura (1991). Ao chegar ao laboratório as amostras foram colocadas em bandejas previamente lavadas com $\mathrm{HNO}_{3}\left(3,17 \mathrm{~mol} \mathrm{~L}{ }^{-1}\right)$, cobertas com papel e colocado para secar a temperatura ambiente. Após secagem, as mesmas foram desagregadas e passadas por uma peneira na fração menor que $2 \mathrm{~mm}$ para a retirada de plantas, pedregulhos e objetos maiores.

O procedimento explicado acima é importante porque, segundo Cota, Rezende e Piovani (2006) os sedimentos são constituídos por "diferentes substratos geoquímicos, os quais possuem alta superfície específica e, portanto, alta capacidade de troca catiônica", sendo um bom indicador do enriquecimento de metais no sedimento. O material resultante da primeira peneira $(2 \mathrm{~mm})$ foi submetido a uma nova etapa de peneirada na fração menor que $63 \mu \mathrm{m}$ (silte/argila) a fim de ser utilizada na determinação dos elementos químicos, matéria orgânica, sólidos voláteis e mineralogia do sedimento. As frações mais finas "compreendem os principais carreadores dos componentes naturais e antropogênicos a partir da coluna d'água" (COTA; REZENDE; PIOVANI, 2006). 


\subsubsection{Decomposição Total do Sedimento}

Tendo em vista que as amostras se encontram em estado sólido e que para sua análise em ICP/OES deve encontrar-se em solução, exceto para determinações em materiais sólidos, então a matriz a ser analisada teve que passar por processo de decomposição a fim de que os metais fossem disponibilizados para a solução. Em análise de sedimentos, geralmente é feito a decomposição completa com a utilização de $\mathrm{HF}$ combinado com $\mathrm{HClO}_{4}, \mathrm{HNO}_{3}$ e $\mathrm{HCl}$. Nesse tipo de decomposição ocorre a liberação total de metais, tanto os ligados à matriz cristalina característico de contribuição natural, quanto aqueles fracamente ligados com disponibilidade potencial para o meio aquático. No presente trabalho, a determinação dos elementos-traço foi realizada a partir da decomposição total dos sedimentos, que consistiu em uma abertura ácida com $\mathrm{HF} / \mathrm{HNO}_{3} / \mathrm{HClO}_{4} / \mathrm{HCl}$ (modificado de BOAVENTURA, 1991) apresentando fator de diluição de 100x (Figura 7). Para determinação de elementos maiores, o procedimento consistiu na fusão com metaborato de lítio (Figura 8) e fator de diluição igual a $10000 x$.

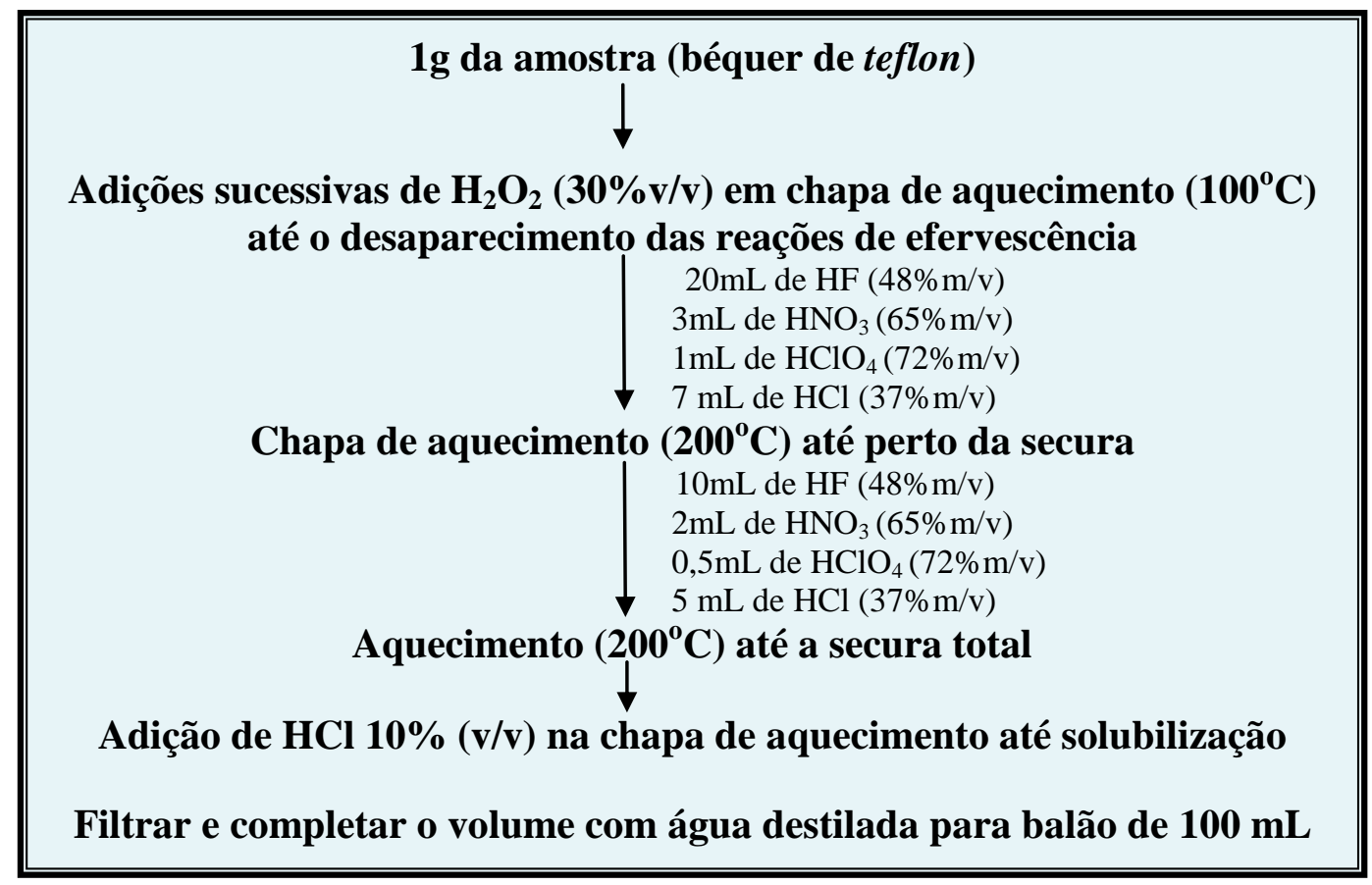

Figura 7- Procedimento de abertura ácida de amostras de sedimento (Ataque III) 


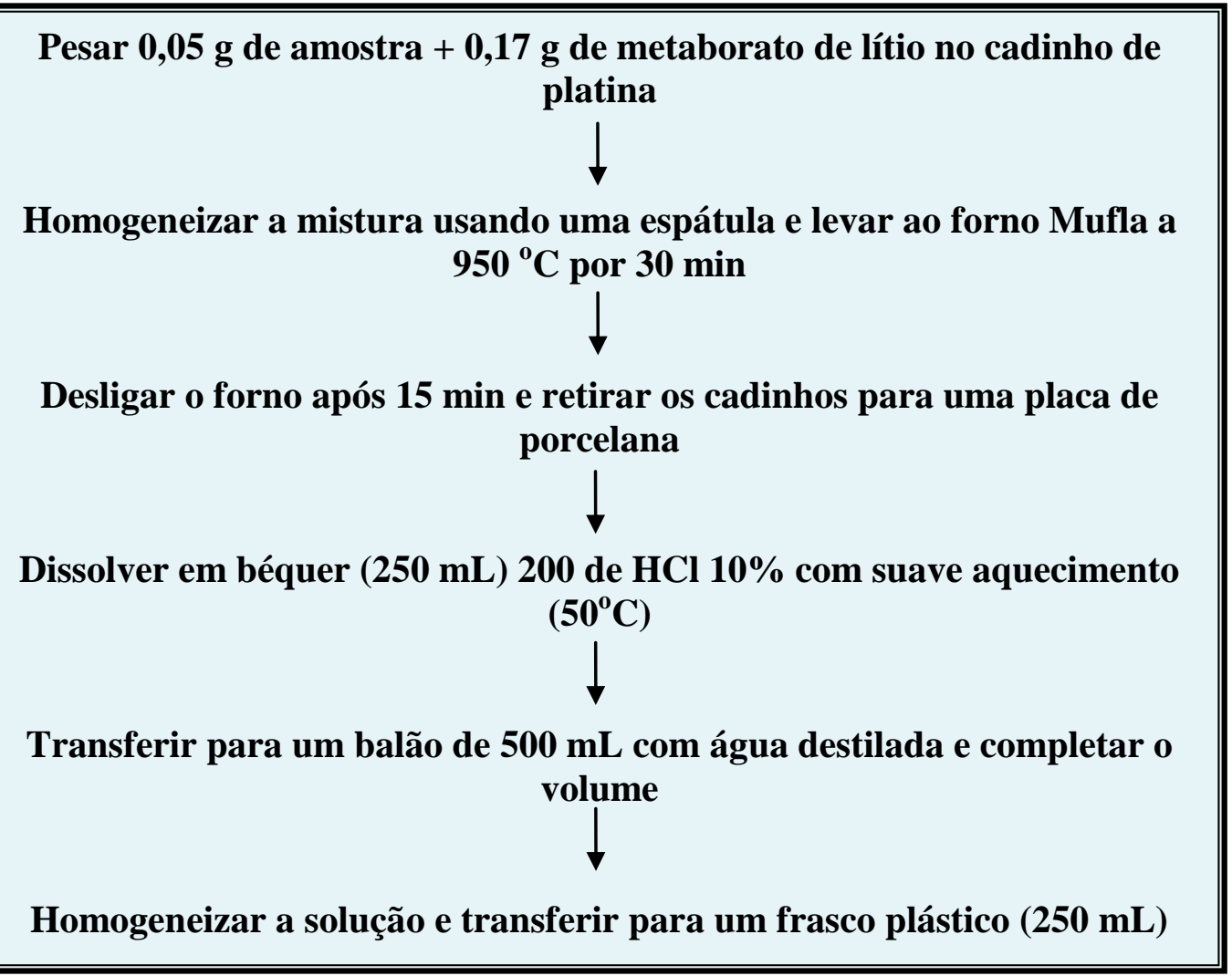

Figura 8- Procedimento de fusão de amostras de sedimento (Ataque II)

\subsubsection{Matéria Orgânica e Sólidos Voláteis}

A matéria orgânica nos solos e nos sedimentos de drenagens é constituída por um complexo grupo de componentes de origem biológica. Ela desempenha papel importante através da formação de complexos estáveis com os compostos metálicos (LICHT, 1998). A determinação da matéria orgânica por ataque químico com o dicromato de potássio em meio sulfúrico é o conhecido método de Walkley-Black (EMBRAPA, 2009). Este método foi utilizado por Moreira e Boaventura (2003) em um estudo no Lago Paranoá (DF) obtendo boas correlações entre o teor de matéria orgânica e sólidos voláteis. Apesar de ter se mostrado apropriado para quantificar a matéria orgânica, Araújo (2012) fazendo um estudo isotópico dos elementos $\mathrm{Cu}$ e Zn no mesmo lago Paranoá (DF), testou duas formas de decompor a matéria orgânica, a primeira utilizando $\mathrm{H}_{2} \mathrm{O}_{2}$ e a segunda realizando a calcinação prévia das amostras ao ataque ácido. Em relação aos sedimentos, a primeira foi eficiente na dissolução da fase mineral e ineficiente na decomposição da matéria orgânica a altos teores. A segunda apresentou alta eficiência na dissolução da matéria orgânica e praticidade na sua execução. 
Baseado nesses resultados optou-se para este estudo, estimar o teor da matéria orgânica pela segunda forma, calcinou-se $1 \mathrm{~g}$ de amostra à $1000^{\circ} \mathrm{C}$ em cadinhos de porcelana durante uma hora em mufla, em seguida, a amostra foi novamente pesada e a partir da diferença entre o peso inicial e final da amostra calculou-se o percentual de matéria orgânica e sólidos voláteis.

\subsubsection{Determinação do P em Sedimento}

Após o tratamento das amostras de sedimento de fundo conforme o item 4.2 .4 e a preparação por digestão via ácida (Ataque III) descrita na Figura 6, preparou-se as soluções de $\left(\mathrm{NH}_{4}\right)_{6} \mathrm{Mo}_{7} \mathrm{O}_{24} .4 \mathrm{H}_{2} \mathrm{O}\left(5 \% \mathrm{~g} \mathrm{~g}^{-1}\right)$ (apenas o suficiente para o dia) e $\mathrm{NH}_{4} \mathrm{VO}_{3}\left(0,25 \% \mathrm{~g} \mathrm{~g}^{-1}\right)(\mathrm{em}$ curtos períodos de tempo) para a determinação do P. O procedimento consistiu em dissolver $50 \mathrm{~g}$ de $\left(\mathrm{NH}_{4}\right)_{6} \mathrm{Mo}_{7} \mathrm{O}_{24} .4 \mathrm{H}_{2} \mathrm{O}$ em $500 \mathrm{~mL}$ de água desmineralizada quente deixando em repouso por várias horas. A solução foi filtrada e diluída para $1000 \mathrm{~mL}$ com água desmineralizada e depois estocada em garrafa de polietileno. Para o $\mathrm{NH}_{4} \mathrm{VO}_{3}\left(0,25 \% \mathrm{~g} \mathrm{~g}^{-1}\right)$ dissolveu 2,5g em $500 \mathrm{~mL}$ de água desmineralizada quente e após esfriar, adicionou $20 \mathrm{~mL}$ de $\mathrm{HNO}_{3} \mathrm{CO}$ deixando esfriar novamente e em repouso várias horas. Filtrou e diluiu a solução para $1000 \mathrm{~mL}$ com água desmineralizada estocando em garrafa de vidro. Para a determinação deste elemento utilizou-se de um padrão titrisol de $\mathrm{PO}_{4}{ }^{3-}$ de um $\mathrm{mg} \mathrm{L}^{-1}$.

A determinação do $\mathrm{P}\left(\mathrm{P}_{2} \mathrm{O}_{5}\right.$ após fator de conversão para óxido) foi realizada através da espectrofometria em um aparelho da marca Spectophotometer modelo T60U. As alíquotas provenientes do ataque III foram colocadas em balões de $100 \mathrm{~mL}$ e adicionadas a elas, os reagentes na seguinte ordem e quantidade: 5,0 mL de $\mathrm{HNO}_{3}$ concentrado; $10,0 \mathrm{~mL}$ de metavanato de amônio $\left(0,25 \% \mathrm{~g} \mathrm{~g}^{-1}\right)$ e $20 \mathrm{~mL}$ de molibdato de amônio (5\% $\left.\mathrm{g} \mathrm{g}^{-1}\right)$ sendo completadas as soluções para $100 \mathrm{~mL}$ com água demineralizada. Depois de homogeneizadas as amostras permaneceram em repouso por 15 minutos e foram lidas em 460nm no mesmo dia juntamente com o branco e a solução padrão de fosfato. 


\subsubsection{Controle Analítico dos dados}

As amostras de água e sedimento de fundo foram analisadas em triplicata e o controle analítico dos resultados validados por amostras de padrão internacional de concentração certificada. Na análise de água, utilizou-se padrões da marca Canadá NWRI (National Water Research Institute) ION-915 e PERADE, lotes 0310 e 1109, respectivamente (Tabela 5 e Tabela 6), água destilada e dados obtidos da água da torneira, cujo acompanhamento é feito pelo Laboratório de Geoquímica da Universidade de Brasília desde 2008. Para sedimentos, usou-se o padrão NIST (National Institute for Standards and Technology - USA) SEM 2709a San Joaquin Soil (Tabela 7) e padrão C de rocha basalto (Tabela 8) na aferição da metodologia de digestão e análise.

Tabela 5 - Resultados obtidos para o padrão ION-915

\begin{tabular}{|c|c|c|c|c|c|c|c|c|c|}
\hline Parâmetro & $\underset{\left(\mathrm{mgL}^{-1}\right)}{\mathbf{C a}}$ & $\underset{\left(\mathrm{mgL}^{-1}\right)}{\mathbf{M g}}$ & $\underset{\left(\mathrm{mgL}^{-1}\right)}{\mathbf{N a}}$ & $\underset{\left(\mathrm{mgL}^{-1}\right)}{\mathbf{K}}$ & $\underset{\left(\mathrm{mgL}^{-1}\right)}{\mathbf{F}^{-}}$ & $\begin{array}{c}\mathrm{Cl}^{-} \\
\left(\mathrm{mg} \mathrm{L}^{-1}\right)\end{array}$ & $\begin{array}{l}\mathbf{N O}_{3}^{-} \\
\left(\mathrm{mgL}^{-1}\right)\end{array}$ & $\begin{array}{l}\mathbf{S O}_{4}{ }^{2-} \\
\left(\mathrm{mgL}^{-1}\right)\end{array}$ & $\underset{\left(\mathrm{mgL}^{-1}\right)}{\mathbf{H C O}_{3}}$ \\
\hline Valor Esperado & 13,40 & 2,80 & 1,35 & 0,49 & $0,05^{\mathrm{b}}$ & 1,39 & 1,52 & 3,40 & 42,30 \\
\hline $\begin{array}{l}\text { Resultado Obtido } \\
\left(\text { média } \pm \mathbf{t}_{\alpha / 2} * \mathbf{d p}^{*} \mathbf{n}^{-1 / 2}\right)\end{array}$ & $\begin{array}{r}13,20 \\
\pm 0,70\end{array}$ & $\begin{array}{c}2,70 \\
\pm 0,20\end{array}$ & $\begin{array}{c}1,42 \\
\pm 0,20\end{array}$ & $\begin{array}{c}0,55 \\
\pm 0,20\end{array}$ & $\begin{array}{r}0,02^{\mathrm{b}} \\
\pm 0,03\end{array}$ & $\begin{array}{c}1,53 \\
\pm 0,08\end{array}$ & $\begin{array}{c}1,45 \\
\pm 0,30\end{array}$ & $\begin{array}{c}3,56 \\
\pm 0,17\end{array}$ & $\begin{array}{l}38,20 \\
\pm 0,50\end{array}$ \\
\hline $\mathbf{C V}^{\mathrm{c}}(\%)$ & 1 & 4 & 5 & 12 & $57^{\mathrm{b}}$ & 10 & 5 & 5 & 10 \\
\hline
\end{tabular}

Tabela 6 - Resultados obtidos para o padrão PERADE

\begin{tabular}{|c|c|c|c|c|c|c|c|c|c|}
\hline Parâmetro & $\begin{array}{c}\mathbf{C a} \\
\left(\mathrm{mgL}^{-1}\right)\end{array}$ & $\underset{\left(\mathrm{mgL}^{-1}\right)}{\mathbf{M g}}$ & $\begin{array}{c}\mathbf{N a} \\
\left(\mathrm{mgL}^{-1}\right)\end{array}$ & $\underset{\left(\mathrm{mgL}^{-1}\right)}{\mathbf{K}}$ & $\begin{array}{c}\mathbf{F}^{-} \\
\left(\mathrm{mgL}^{-1}\right)\end{array}$ & $\begin{array}{c}\mathrm{Cl}^{-} \\
\left(\mathrm{mg} \mathrm{L}^{-1}\right)\end{array}$ & $\begin{array}{l}\mathbf{N O}_{3}^{-} \\
\left(\mathrm{mgL}^{-1}\right)\end{array}$ & $\begin{array}{l}\mathbf{S O}_{4}{ }^{2-} \\
\left(\mathrm{mgL}^{-1}\right)\end{array}$ & $\begin{array}{r}\mathbf{H C O}_{3}^{-} \\
\left(\mathrm{mgL}^{-1}\right)\end{array}$ \\
\hline Valor Esperado & 3,04 & 0,44 & 1,50 & 0,36 & $0,04^{b}$ & 0,96 & 1,02 & 3,26 & 6,35 \\
\hline 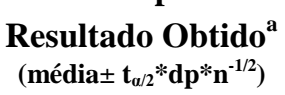 & $\begin{array}{c}3,22 \\
\pm 0,25\end{array}$ & $\begin{array}{c}0,45 \\
\pm 0,06\end{array}$ & $\begin{array}{c}1,60 \\
\pm 0,09\end{array}$ & $\begin{array}{c}0,37 \\
\pm 0,06\end{array}$ & $\begin{array}{r}0,04^{\mathrm{b}} \\
\pm 0,01\end{array}$ & $\begin{array}{c}0,95 \\
\pm 0,08\end{array}$ & $\begin{array}{c}0,90 \\
\pm 0,05\end{array}$ & $\begin{array}{c}3,35 \\
\pm 0,09\end{array}$ & $\begin{array}{c}6,64 \\
\pm 0,02\end{array}$ \\
\hline $\mathbf{C V}^{\mathrm{c}}(\%)$ & 6 & 1 & 5 & 3 & $0^{\mathrm{b}}$ & 1 & 11 & 3 & 5 \\
\hline
\end{tabular}

${ }^{\mathrm{a}}$ série temporal de 2011 a $2014 ;{ }^{\mathrm{b}}$ resultado não significativo $<$ LQ segundo tabela $9 ;{ }^{\mathrm{c}}$ Coeficiente de variação=dp x média ${ }^{-1}$ 
Tabela 7 - Resultados obtidos para o padrão SAN JOAQUIN SOIL

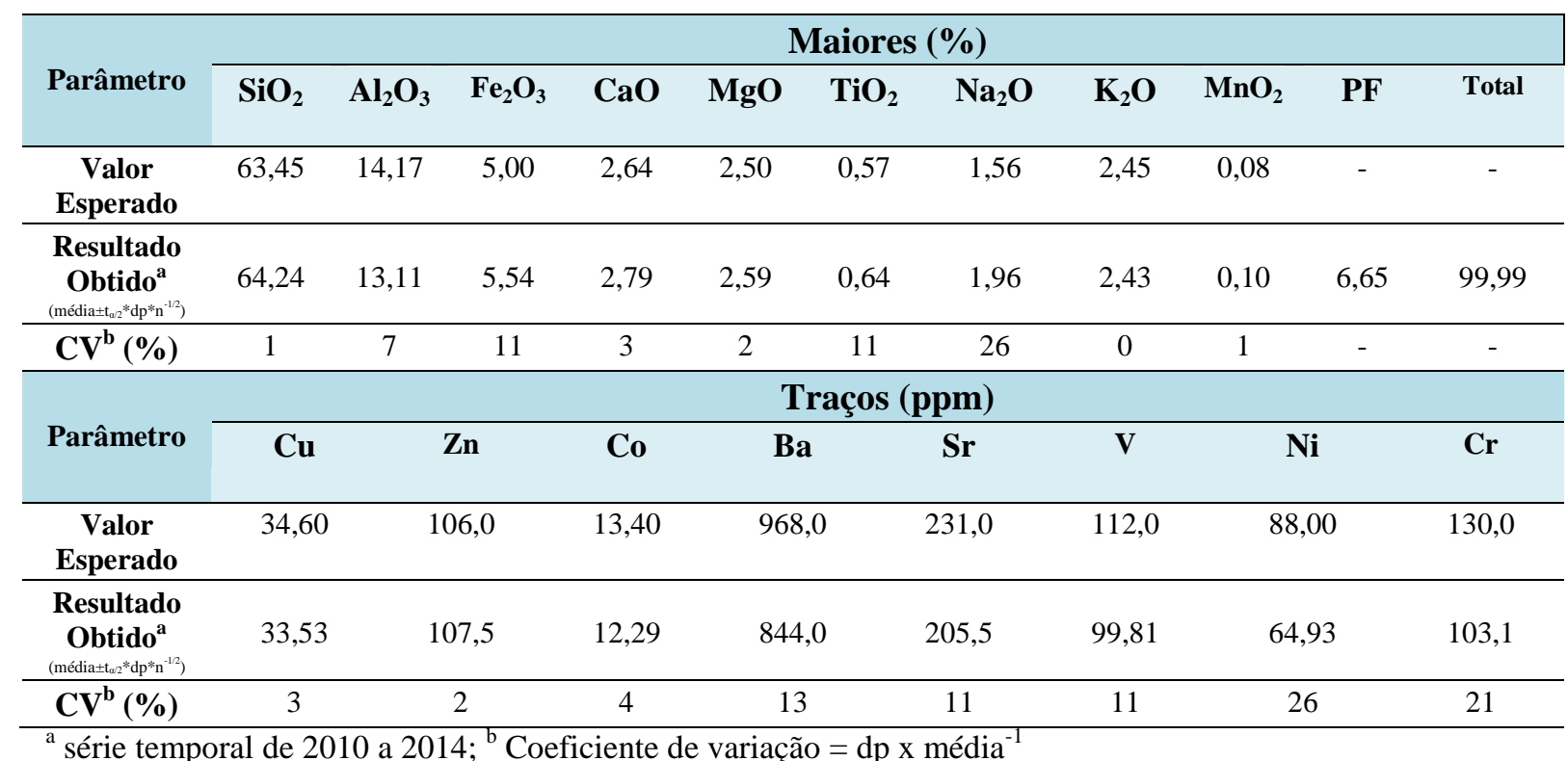

Tabela 8 - Controle de qualidade do padrão C - basalto

\begin{tabular}{|c|c|c|c|c|c|c|c|c|c|c|c|}
\hline \multirow[b]{2}{*}{ Parâmetro } & \multicolumn{11}{|c|}{ Maiores (\%) } \\
\hline & $\mathrm{SiO}_{2}$ & $\mathrm{Al}_{2} \mathrm{O}_{3}$ & $\mathrm{Fe}_{2} \mathrm{O}_{3}$ & $\mathrm{CaO}$ & MgO & $\mathrm{TiO}_{2}$ & $\mathrm{Na}_{2} \mathrm{O}$ & $\mathbf{K}_{2} \mathbf{O}$ & $\mathrm{MnO}_{2}$ & PF & Total \\
\hline $\begin{array}{c}\text { Valor } \\
\text { Esperado }\end{array}$ & 50,00 & 12,50 & 15,80 & 9,00 & 5,20 & 4,04 & 2,66 & 0,75 & 0,20 & - & - \\
\hline 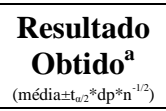 & 50,00 & 12,96 & 14,78 & 9,54 & 5,00 & 4,01 & 2,43 & 0,64 & 0,20 & 0,46 & 99,99 \\
\hline $\mathrm{CV}^{\mathbf{b}}(\%)$ & 3 & 9 & 6 & 4 & 3 & 2 & 4 & 10 & 3 & 9 & 3 \\
\hline \multirow[b]{2}{*}{ Parâmetro } & \multicolumn{11}{|c|}{ Traços (ppm) } \\
\hline & $\mathrm{Cu}$ & & $\mathbf{Z n}$ & Co & $\mathbf{B a}$ & & $\mathbf{S r}$ & $\mathbf{V}$ & $\mathbf{N i}$ & & $\mathrm{Cr}$ \\
\hline $\begin{array}{c}\text { Valor } \\
\text { Esperado }\end{array}$ & 110,0 & & 3,00 & 115,0 & 410,0 & & 498,0 & 470,0 & 50,00 & & 51,00 \\
\hline 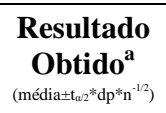 & 117,1 & & 28,6 & 106,4 & 389,4 & & 490,1 & 515,9 & 60,92 & & 70,42 \\
\hline $\mathrm{CV}^{\mathbf{b}}(\%)$ & 10 & & 7 & 6 & 3 & & 1 & 10 & 43 & & 13 \\
\hline
\end{tabular}

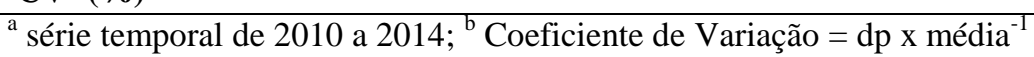

As curvas analíticas do EAA, ICP/OES e IC foram preparadas com soluções padrões de $1000 \mathrm{mg} \mathrm{L}^{-1}$ da marca Vetec e a partir delas, feitas as diluições necessárias para cada elemento. Todas as metodologias utilizadas nas análises químicas seguiram orientações do Standard Methods for the Examination of Water and Wastewater; $20^{\mathrm{a}}$ edição da American Public Health Association (APHA), da American Water Works Association (AWWA), e da 
Water Pollution Control Federation (WPCF). Os parâmetros de validação: limite de detecção (LD), limite de quantificação (LQ), coeficiente de regressão e faixa linear de trabalho foram calculados a partir de cinco leituras das curvas de calibração respectivas (Tabela 9). O limite de quantificação (LQ) considerado foi 10x o limite de detecção (LD).

Tabela 9 - Resultados estatísticos relevantes e figuras de mérito obtidas pela análise de 5 curvas de calibração independentes lidas em 3 dias diferentes

\begin{tabular}{|c|c|c|c|c|c|}
\hline Equipamento & Parâmetro & $\mathbf{L D}^{\mathrm{a}}\left(\mathrm{mg} \mathrm{L}^{-1}\right)$ & $\mathbf{L} Q^{b}\left(\mathrm{mg} \mathrm{L}^{-1}\right)$ & FLT $^{\mathrm{c}}\left(\mathrm{mg} \mathrm{L}^{-1}\right)$ & $R 2^{d}$ \\
\hline \multirow[b]{2}{*}{$\mathbf{A A}$} & $\mathrm{Na}$ & 0,02 & 0,09 & $0,5-5$ & 0,99 \\
\hline & $\mathbf{K}$ & 0,03 & 0,09 & $0,5-5$ & 0,99 \\
\hline \multirow{5}{*}{ IC } & $\mathbf{F}^{-}$ & 0,01 & 0,08 & $0,2-1$ & 0,99 \\
\hline & $\mathrm{Cl}^{-}$ & 0,05 & 0,18 & $0,5-10$ & 0,99 \\
\hline & $\mathrm{NO}_{3}^{-}$ & 0,02 & 0,08 & $0,2-10$ & 0,99 \\
\hline & $\mathrm{PO}_{4}{ }^{3-}$ & 0,01 & 0,02 & $0,2-5$ & 0,98 \\
\hline & $\mathrm{SO}_{4}{ }^{2-}$ & 0,05 & 0,20 & $0,7-15$ & 0,99 \\
\hline \multirow{15}{*}{ ICP/OES } & $\mathrm{Si}$ & 0,011 & 0,10 & $1,0-10$ & 0,99 \\
\hline & Al & 0,027 & 0,20 & $1,0-30$ & 0,98 \\
\hline & $\mathbf{F e}$ & 0,022 & 0,20 & $1,0-20$ & 0,99 \\
\hline & $\mathrm{Ca}$ & 0,066 & 0,60 & $0,8-40$ & 0,97 \\
\hline & Mg & 0,017 & 0,10 & $2,0-18$ & 0,99 \\
\hline & $\mathbf{T i}$ & 0,03 & 0,40 & $1,0-10$ & 0,99 \\
\hline & $\mathrm{Cu}$ & 0,20 & 2,00 & $2,0-4$ & 0,98 \\
\hline & $\mathbf{Z n}$ & 0,04 & 0,40 & $0,8-4$ & 0,99 \\
\hline & Co & 0,18 & 1,18 & $1,3-4$ & 0,99 \\
\hline & $\mathbf{B a}$ & 0,30 & 3,00 & $4,0-20$ & 0,98 \\
\hline & $\mathbf{S r}$ & 0,30 & 3,00 & $3,5-20$ & 0,98 \\
\hline & Mn & 0,01 & 0,10 & $0,7-20$ & 0,99 \\
\hline & $\mathbf{V}$ & 0,20 & 2,00 & $2,0-20$ & 0,99 \\
\hline & $\mathbf{N i}$ & 0,15 & 1,50 & $1,7-20$ & 0,99 \\
\hline & $\mathrm{Cr}$ & 0,20 & 2,00 & $2,7-20$ & 0,99 \\
\hline
\end{tabular}

${ }^{a}$ Limite de detecção, calculado pelo aparelho em relação ao BEC ou ruído do aparelho; ${ }^{b}$ Limite de quantificação: para AA e IC foi calculado pela curva de calibração: $10 \mathrm{x} \mathrm{S}_{\mathrm{y} / \mathrm{x}} \mathrm{x}^{-1}\left(\mathrm{~S}_{\mathrm{y} / \mathrm{x}}=\right.$ desvio padrão da curva de resíduos para ao ajuste linear e $\mathrm{b}=$ coeficiente angular da curva de resíduos) ou; para ICP/OES foi igual a 10x o valor do LD; ${ }^{\mathrm{c}}$ Faixa linear de trabalho obtida pelo teste de homocedasticidade; ${ }^{\mathrm{d}}$ Coeficiente de correlação da curva de calibração.

\subsubsection{Análise Mineralógica por Difração de Raio-X}

Todas as frações utilizadas para determinação dos metais $(<63 \mu \mathrm{m})$, foram submetidas à análise de difratometria de Raios-X (DRX) no Laboratório de Difratometria de Raio-X da 
UnB. Essa análise consistiu em três varreduras distintas: uma da amostra total $(\mathrm{T})$ e duas da fração argila: orientada e seca ao ar $(\mathrm{N})$ e com etilenoglicol $(\mathrm{G})$. Na análise de T, as amostras foram pulverizadas, compactadas a seco em lâminas vazadas e analisadas. Para a obtenção da fração argila, as amostras liquidificadas com água destilada foram submetidas à centrifugação e em seguida colocadas em lâminas orientadas para a leitura da fração argila normal e depois glicoladas passando pelo processo de leitura. As análises de Difratometria de Raios-X foram procedidas utilizando-se de um aparelho Rigaku $D-M A X B$ com radiação de $C u K \alpha$, velocidade de varredura de $2 \min ^{-1}$ e intervalo de medida de $0,05^{\circ}$. O intervalo de varredura foi de 2 a $65^{\circ}$ para $\mathrm{T}$ e de 2 a $35^{\circ}$ para $\mathrm{N}$ e $\mathrm{G}$. $\mathrm{Na}$ interpretação dos difratogramas bem como a identificação dos minerais utilizou-se o software JADE 3.0 Windows, XRD Pattern Procesing for the PC, 1991-1995 Materials Data, Inc.

\subsection{Procedimentos Microbiológicos Analíticos em Água Bruta}

A análise das amostras microbiológicas realizada no laboratório da SANEAGO/SA seguiu os protocolos estabelecidos pela American Public Health Association (APHA, 2005) procedendo a determinação do Número Mais Provável (NMP/100 mL) de Coliformes Totais e Escherichia Coli. A enumeração de Coliformes Totais e Escherichia Coli foram obtidas através da técnica dos tubos múltiplos com substrato enzimático cromogênico 1-isopropil- $\beta$ D-1-tio-galactopiranosídio (IPTG), 5-bromo-4-cloro-3-indolil- $\beta$-D-galactopiranosídeo (XGAL) e fluorogênico 4-metilumbeliferil- $\beta$-D-glicoronideo (MUG).

Utilizando-se três séries de cinco tubos contendo caldo fluorocult lauril sulfato, inoculou-se $1 \mathrm{~mL}$ da amostra na primeira série, e nas $2^{\mathrm{a}}$ e $3^{\mathrm{a}}$ séries, $1 \mathrm{~mL}$ da diluição $10^{-1}$ e 1 $\mathrm{mL}$ da diluição $10^{-2}$, respectivamente, empregando como diluente, $9 \mathrm{~mL}$ de água peptonada tamponada. Após homogeneização, os tubos foram incubados de 18 a 24 horas a $35{ }^{\circ} \mathrm{C}$ sendo consideradas positivas para Coliformes Totais as amostras que apresentaram coloração verdeazulada.

Para a confirmação de E.Coli, os tubos positivos de Coliformes Totais foram submetidos à luz ultravioleta de 336nm de comprimento de onda. O MUG, composto não fluorescente, utilizado como substrato para indicar a presença da enzima $\beta$-glicuronidase produzida pela E. Coli, ao ser degradado, forma um produto (4-metilumbeliferona) fluorescente sob luz ultravioleta de onda longa (336nm). Foram considerados positivos para a 
presença de E. Coli., aqueles tubos que apresentaram coloração verde-azulada e com desenvolvimento de fluorescência azul sob luz ultravioleta (4W), ondas longas (366nm) em uma cabine escura.

Para a confirmação adicional da presença de E.Coli gotejou-se o reativo de Indol, segundo Kovacs, nos tubos que apresentaram fluorescência. O desenvolvimento de um anel vermelho-rosado na superfície do tubo indicava reação positiva, pois o triptofano presente na composição do meio é desdobrado pela enzima triptofanase da E.Coli produzindo indol. $\mathrm{O}$ Número Mais Provável (NMP) foi calculado a partir da combinação de números de tubos positivos e negativos em três séries de cinco tubos, empregando-se a tabela conforme o protocolo descrito pela APHA (2005). A Figura 9 apresenta o fluxograma de enumeração de Coliformes Totais e Escherichia Coli.

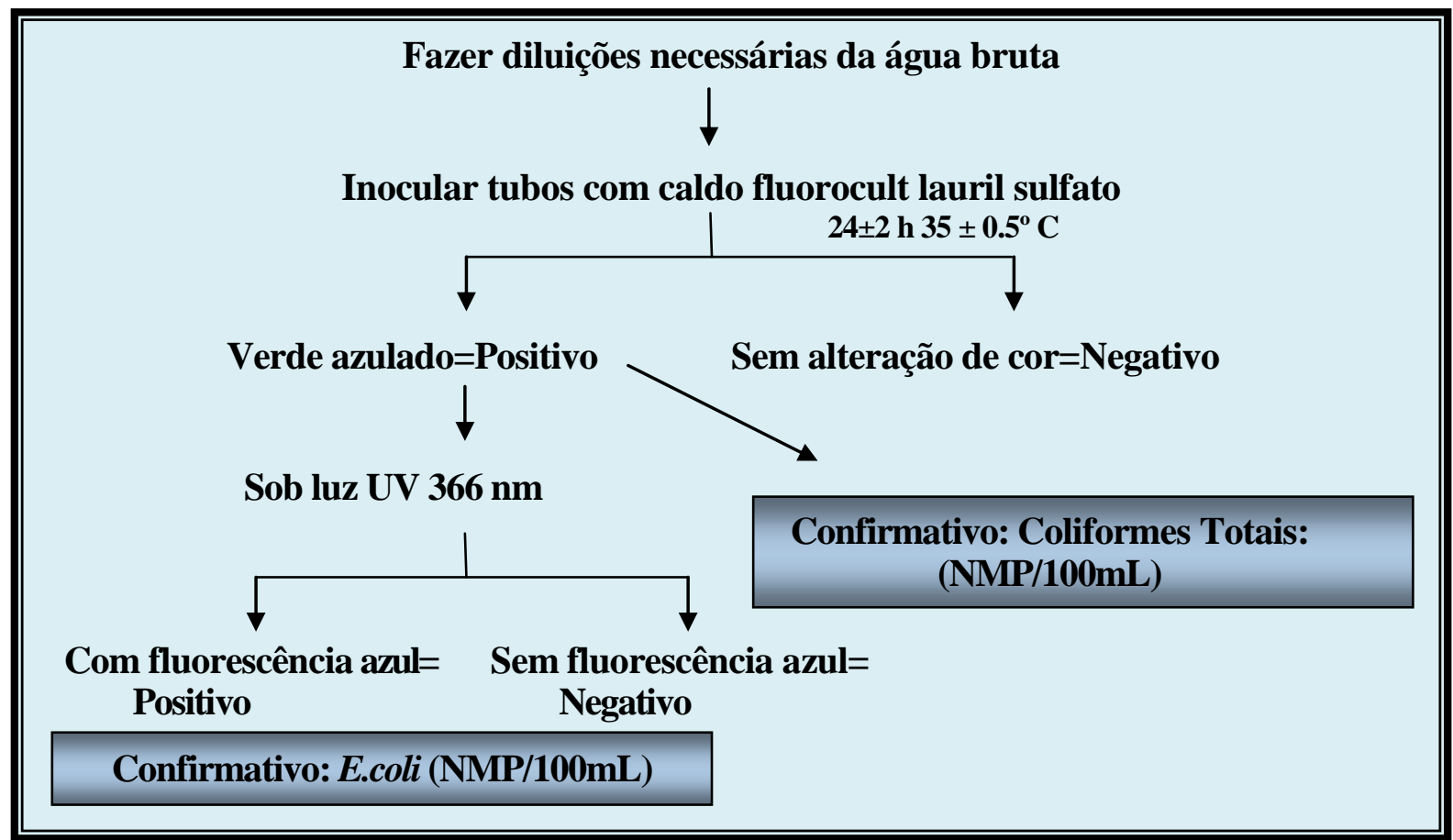

Figura 9- Fluxograma da enumeração de Coliformes Totais e Escherichia Coli em água bruta - Técnica dos Tubos Múltiplos (NMP) com substrato enzimático.

\subsection{Métodos Estatísticos}

Neste estudo optou-se por usar técnicas de análises multivariadas que reduzem a grande quantidade de dados em um pequeno número de fatores a fim de serem melhores interpretados (VOUDOURIS et al., 2000). Os dados foram submetidos à Correlação de 
Spearman juntamente com o Agrupamento Hierárquico. Esses métodos e programas estatísticos estão disponibilizados no site do Portal Action (http://www.portalaction.com.br. Acesso 30/07/2013), cujo software desenvolvido é integrado ao Excel (2007). Para a Correlação de Spearman considerou correlação significativa valores $\geq 50 \%$. Como a amostragem foi realizada nos dois períodos (seca e chuva), confeccionaram-se duas matrizes de correlação distintas para análises de água (uma para cada período) e outra para análises de sedimentos de fundo. Considerando que os elementos provêm das mesmas fontes, o agrupamento hierárquico abrangeu apenas correlações ocorridas simultaneamente nos dois períodos, seca e chuva, e as correlações significativas em análises de sedimento de fundo.

\subsubsection{Tratamento dos Dados}

O uso de algumas técnicas estatísticas apresenta resultados confiáveis se as observações não registrarem valores nulos, ausentes e letras/símbolos tendo como consideração a existência das três possibilidades de resultados: o valor nulo, valores reais e valores abaixo do limite de detecção. Como os aparelhos espectrômetros de emissão atômica e de massa costumam ter limitações na detecção de determinados elementos por não conseguirem quantificá-los, estes exibem valores nulos, o que não significa ausência do elemento na amostra, mas sim, valores abaixo da capacidade de percepção do aparelho (BARROS, 2002). Para evitar distorções nos resultados estatísticos deste estudo, as concentrações abaixo do limite de detecção $(<\mathrm{LD})$ detectadas pelo ICP/OES de algumas amostras foram substituídas por valores correspondentes à metade do LD para aquele parâmetro. Valores nulos (zero) nas determinações receberam metade do menor valor da série para aquele parâmetro. Tais procedimentos acima foram propostos e aplicados por Chen et al.(2007) e Petersen et al. (2001) com o único objetivo de não perder informações.

\subsubsection{Correlação de Spearman}

Para avaliar a relação de intensidade, direção da relação linear ou não-linear entre duas ou mais variáveis foi utilizada a análise de coeficiente de Correlação de Spearman, método mais indicado, segundo Guilford (1950) para um número pequeno de amostras $(<30)$. Esse método fornece a mesma estimativa do Coeficiente de Correlação Linear de Pearson, a 
diferença é que ele não é sensível a assimetrias na distribuição, nem à presença de outliers, não exigindo que os dados provenham de duas populações normais.

O coeficiente $\rho$ de Spearman varia entre -1 e 1 . Quanto mais próximo estiver destes extremos, maior será a associação entre as variáveis. O sinal negativo da correlação significa que as variáveis variam em sentido contrário, isto é, as categorias mais elevadas de uma variável estão associadas a categorias mais baixas da outra variável. Essa correlação é uma ferramenta muito importante, pois avalia a relação entre duas medidas quantitativas sendo possível verificar a associação entre elas e também predizer o valor de uma variável a partir de outra.

\subsubsection{Análise de agrupamento (Cluster Analysis) Hierárquico}

Para reunir os parâmetros, observações semelhantes e separar os mais distantes, recorreu-se à análise de agrupamento hierárquico. O agrupamento hierárquico unifica os parâmetros em classes (clusters) ou grupos na qual a variação das observações é similar (SINGH et al., 2005). Primeiramente, os objetos mais similares são agrupados formando um único grupo e o processo é repetido. Com o decréscimo da similaridade, todos os subgrupos são agrupados, formando um único grupo com todos os objetos (VICINI, 2005). Os resultados são representados graficamente em um dendograma sintetizando as análises do trabalho desenvolvido. Nele ocorre uma pequena perda da informação, mas nada que comprometa o desenvolvimento do mesmo, demonstrando grande utilidade para a classificação, comparação e discussão de agrupamentos (VICINI, 2005).

\subsection{4 Índice de Geoacumulação ( $\left.\mathrm{I}_{\text {geo }}\right)$}

O $\mathrm{I}_{\text {geo }}$, proposto por Müller em 1979, é utilizado na avaliação da intensidade de acumulação de metais no sedimento em relação aos valores background. Originalmente, estabelece a relação entre os teores de metais encontrados na região em análise e um valor referencial equivalente à média mundial para metais associados a argilas (MALM et al., 1989). O valor obtido permite classificar os níveis de enriquecimento dos metais em sete estratos, com intensidades progressivas, que variam de 0 a 6 . O valor mais alto corresponde a um enriquecimento de aproximadamente 100 vezes em relação ao nível de background. $\mathrm{O} \mathrm{I}_{\text {geo }}$ 
é uma medida quantitativa calculada pela fórmula:

$$
\mathrm{I}_{\mathrm{geo}}=\log _{2} \frac{\mathrm{C}_{\mathrm{n}}}{1,5 \times \mathrm{C}_{\mathrm{b}}}
$$

Onde:

- $\mathrm{C}_{\mathrm{n}}$ é a concentração do elemento a ser classificado;

- $\mathrm{C}_{\mathrm{b}}$ é a concentração média de background;

- 1.5 é o fator de correção para possíveis variações no background devido a efeitos litogênicos (FÖRSTNER, 1983).

A Tabela 10 demonstra a classificação de acordo com o índice obtido.

Tabela 10 - Classificação do Índice de geoacumulação e descrição da qualidade do sedimento

\begin{tabular}{lll}
\hline Acumulação & Classe & Igeo \\
\hline Extrema & 6 & Igeo $>5$ \\
Forte a Extrema & 5 & $4<$ Igeo $<5$ \\
Forte & 4 & $3<$ Igeo $<4$ \\
Moderada a Forte & 3 & $2<$ Igeo $<3$ \\
Moderada & 2 & $1<$ Igeo $<2$ \\
Ausente à Moderada & 1 & $0<$ Igeo $<1$ \\
Ausente & 0 & Igeo $<0$ \\
\hline
\end{tabular}

Neste trabalho, o cálculo dos índices foi adaptado às concentrações obtidas na fração silte/argila $<63 \mu \mathrm{m}$ seguindo os procedimentos prescritos por Moreira e Boaventura (2003) onde, $\mathrm{C}_{\mathrm{n}}$ passa a ser a concentração do elemento $\mathrm{n}$ na fração silte+argila do sedimento a ser classificado e $\mathrm{C}_{\mathrm{b}}$, a concentração média de background da área de controle. Tal procedimento representa de forma objetiva as contribuições litológicas da área de estudo (MOREIRA; BOAVENTURA, 2003). 


\subsection{Determinação dos Parâmetros Físico-Químicos e Microbiológicos da Água}

Os parâmetros físico-químicos, além de discriminar a qualidade dos rios são os mais influenciados pelas estações do ano (SILVA et al., 2008). Os elementos químicos Ti, Cu, Zn, $\mathrm{Co}, \mathrm{Ba}, \mathrm{Sr}, \mathrm{V}, \mathrm{Ni}$ e Cr dissolvidos nas amostras de água ficaram abaixo da quantificação do método estabelecido para este estudo não sendo possível sua avaliação geoquímica em água, apenas em sedimentos de fundo.

\subsubsection{Parâmetros Físicos da Água: Temperatura e Turbidez}

A temperatura do Rio das Antas não apresentou grandes mudanças nas estações seca e chuvosa nem diferenças significativas entre os pontos amostrados. Registrou valores de $18^{\circ}$ a $26{ }^{\circ} \mathrm{C}$ na seca e $21^{\circ}$ a $29{ }^{\circ} \mathrm{C}$ na chuvosa, apresentando leve acréscimo entre as estações conforme Figura 10. A diferença registrada entre as temperaturas nos dois períodos está diretamente ligada às estações do ano, no hemisfério sul, a seca coincide com o período do inverno, época de dias mais frios e curtos.

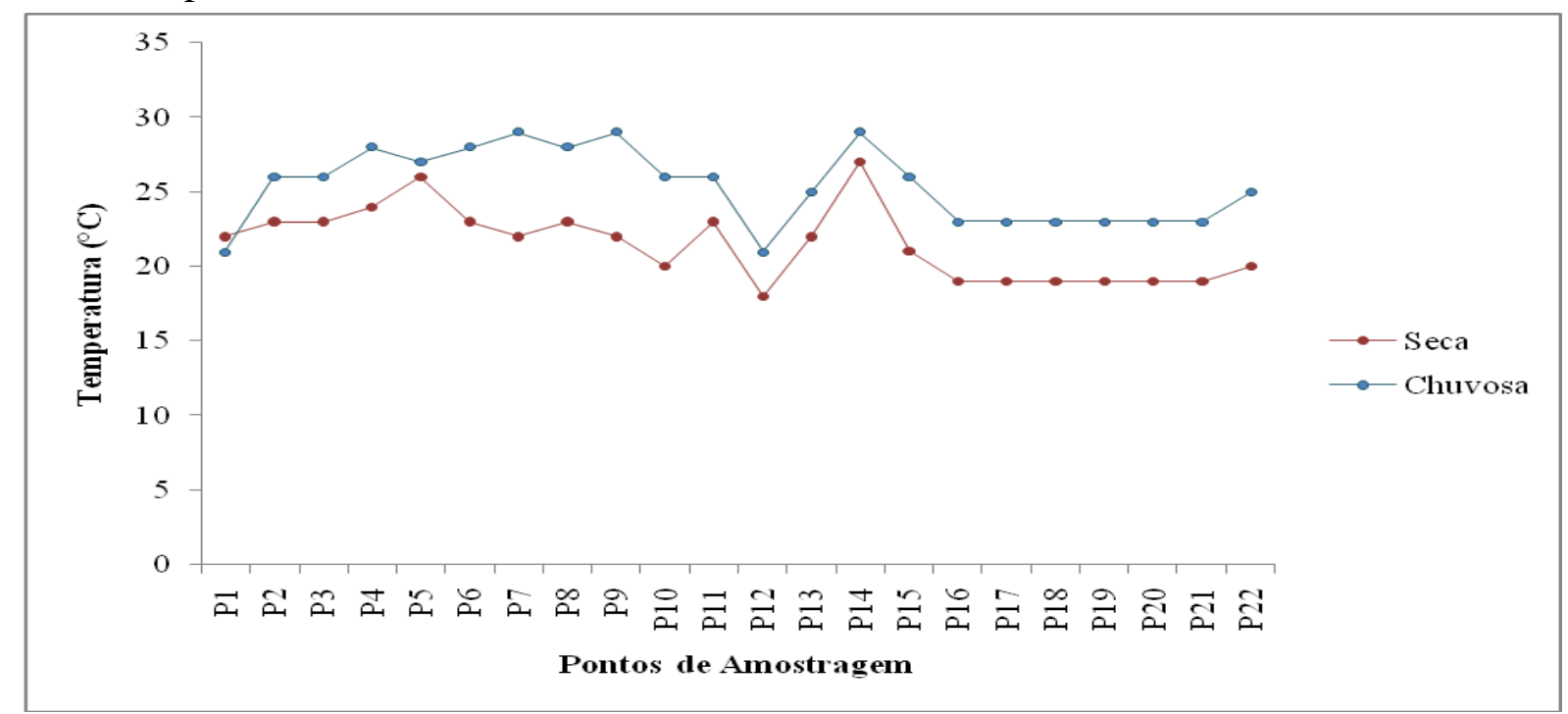

Figura 10 - Gráfico de temperatura $\left({ }^{\circ} \mathrm{C}\right)$ das águas do Rio das Antas nas estações seca e chuvosa. 
De modo geral, a turbidez encontrou-se excessivamente carregada no período chuvoso indicando que a precipitação pluviométrica e o runoff influenciaram na concentração desse parâmetro (Figura 11). As fontes dos materiais suspensos ou dissolvidos nas águas do Rio das Antas estão ligadas a partículas de solos erodidos em taludes desmatados do rio, principalmente no ponto P5 (seca).

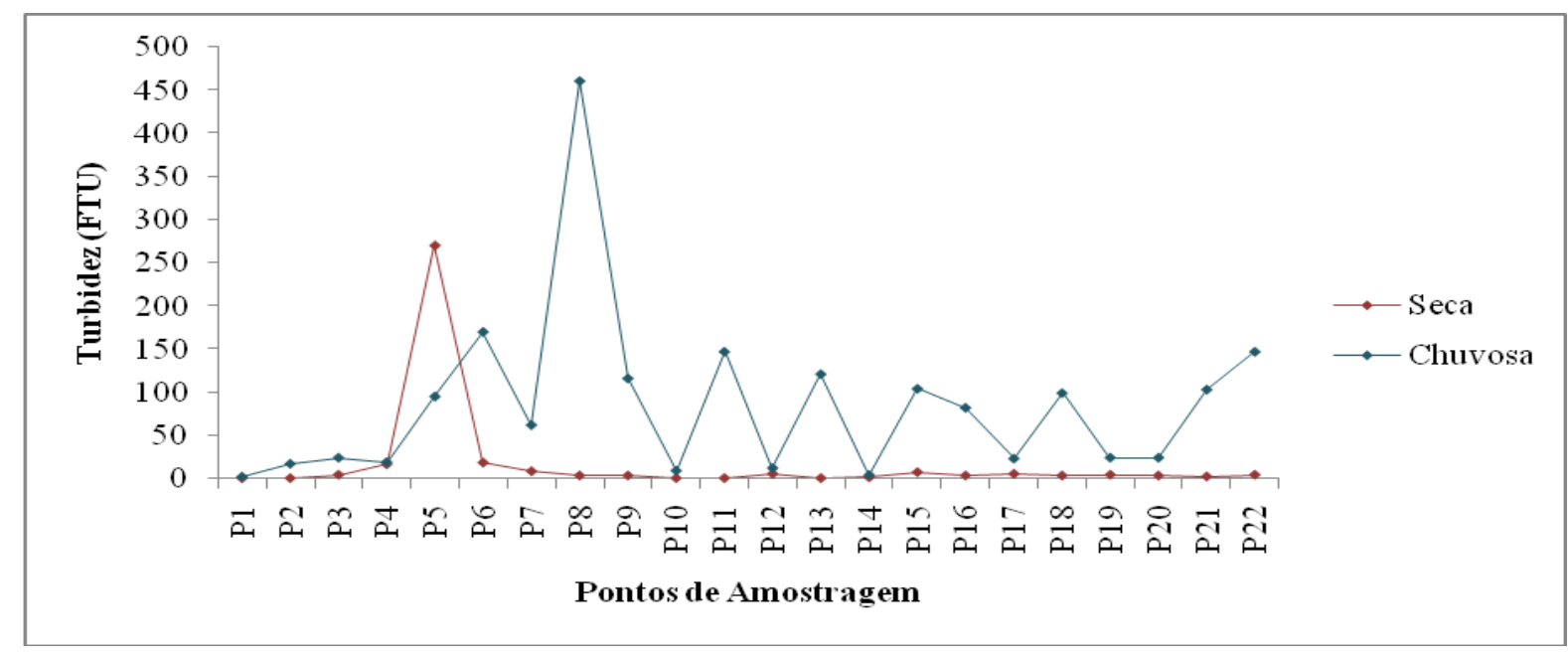

Figura 11 - Turbidez (FTU) das águas do Rio das Antas nas estações seca e chuvosa.

No período da seca, o decréscimo no valor da turbidez aconteceu pela influencia da menor quantidade no volume de água e dos meandros formados em terrenos planos facilitando a deposição dos materiais particulados nos aluviões. Escoamentos de diversos materiais inorgânicos, orgânicos, solo, além dos processos habituais de intemperismo das rochas e erosão contribuíram para os altos valores de turbidez registrados no período chuvoso. Importante ressaltar que os elevados valores de turbidez a partir do ponto P5 (chuva) se devem também a obras de engenharia civil realizadas para melhorias de canaletas de drenagem e construção de viadutos no município de Anápolis (Figura 12). A anomalia localizada em P8 (estação chuvosa) aconteceu por coincidência de horários entre a lavagem dos filtros da estação de tratamento de água (ETA) e o horário da coleta da amostra, diariamente descargas de efluentes in natura da ETA são periodicamente lançados no tributário do Rio das Antas (Corrego dos Cesários).

Baixos valores de turbidez no período chuvoso se encontram em locais amostrados com vegetação preservada diminuindo o escoamento superficial de particulados e matéria orgânica. À jusante da área de estudo (P21 e 22, estação chuvosa) observa-se novamente aumento da turbidez onde há falta de cobertura natural em solos removidos para agricultura. 


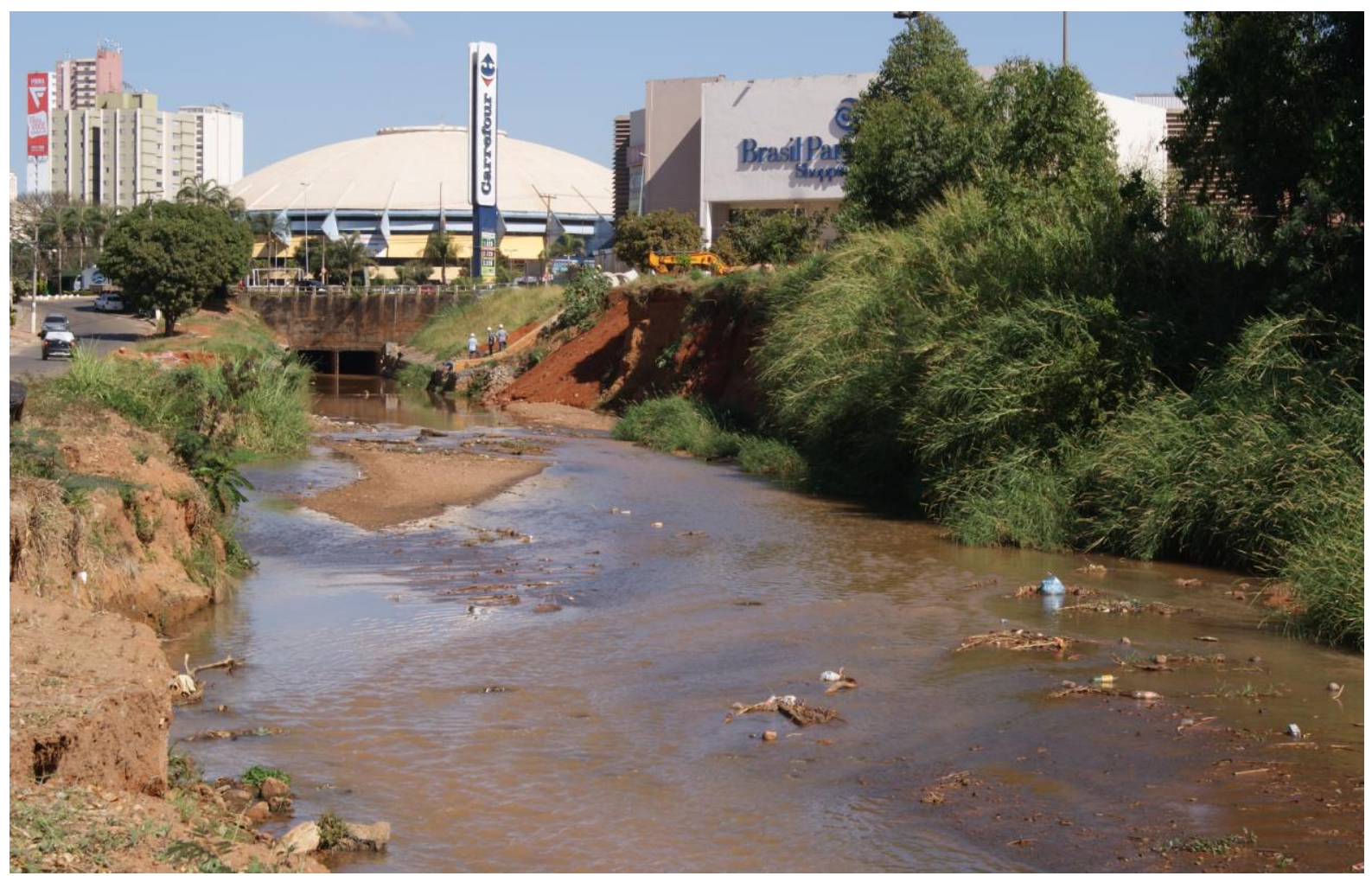

Figura 12 - Panorama do Rio das Antas na região central do município de Anápolis/GO. Construção de novos canais de drenagem e do viaduto.

\subsubsection{Total de Sólidos Dissolvidos (TDS) e Parâmetros Químicos da Água: Condutividade Elétrica (CE), $\mathrm{Ca}, \mathrm{Mg}, \mathrm{Na}$ e $\mathrm{K}, \mathrm{Cl}^{-}, \mathrm{NH}_{3}, \mathrm{NO}_{3}{ }^{-}, \mathrm{PO}_{4}{ }^{3-}$}

A CE e o TDS apresentaram proporcionalidade na concentração de íons. Se comparados entre si, percebe-se que há uma analogia linear para a condutividade em relação aos sólidos totais e dissolvidos (SAMPAIO et al., 2007) (Figura 13A e 13B). 


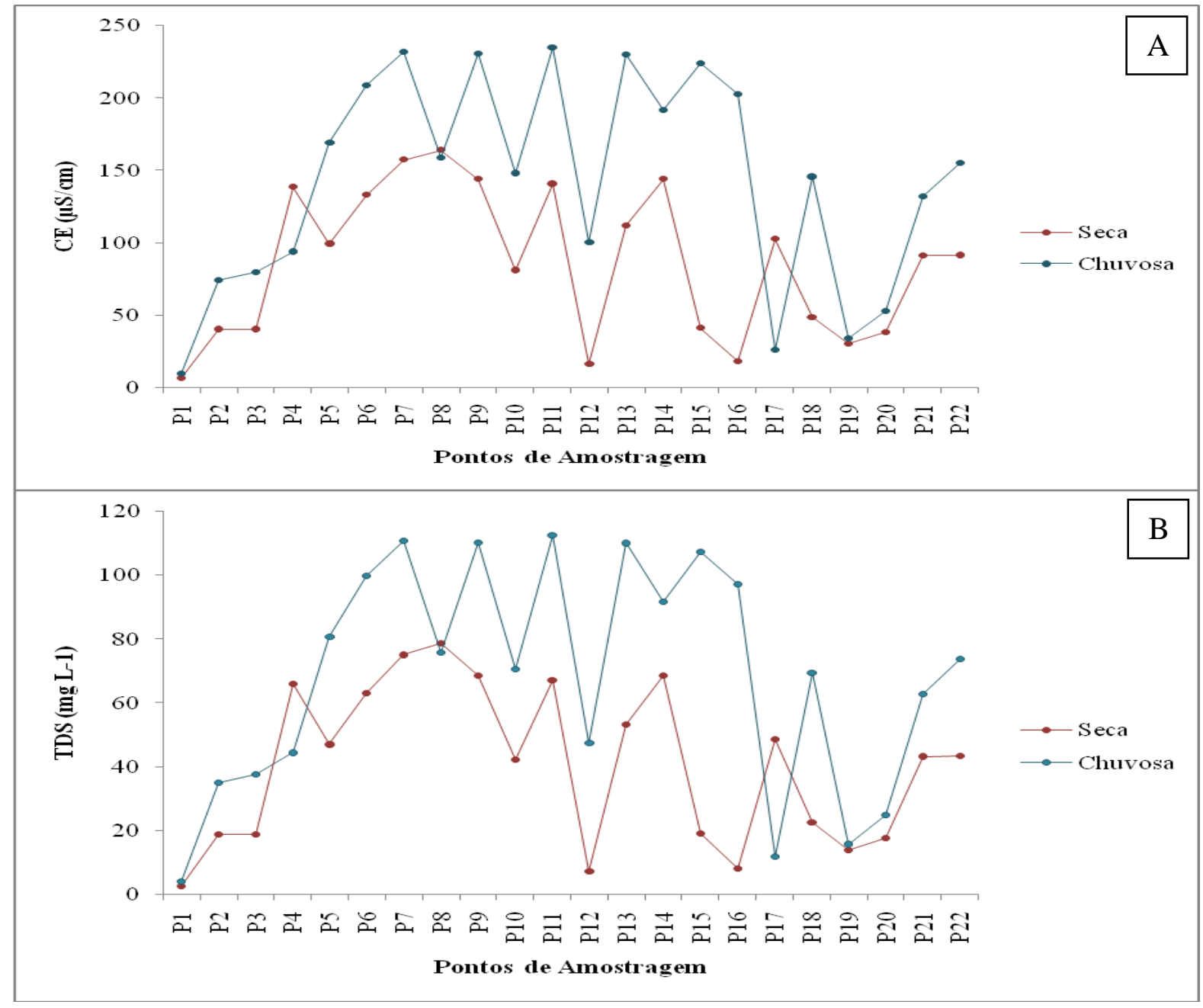

Figura 13 - (A) Valores de $C E(\mu S / \mathrm{cm})$ e (B) TDS $\left(\mathrm{mg} \mathrm{L}^{-1}\right)$ das águas do Rio das Antas nas estações seca e chuvosa.

A partir dos gráficos, observa-se que valores de CE e TDS variaram de montante a jusante apresentando concentrações maiores em seu curso que passa pelo intenso perímetro urbano e lavouras. Para Esteves (1998) apud Petruf, Sacco e Lucio (2011), os íons diretamente responsáveis pela alta da $\mathrm{CE}$ são os macronutrientes $\mathrm{Ca}, \mathrm{Mg}$, $\mathrm{Na}$ e $\mathrm{K}$. No sistema lótico em questão, esses elementos químicos foram encontrados em valores elevados, lançados pela drenagem de terrenos agrícolas ao sul dos locais amostrados, e em menor escala, disponibilizados pelos minerais extraídos de rochas silicatadas (granito) e calcissilicáticas (rochas metamórficas com protólito rico em magnésio, cálcio e sílica) do Complexo Granulítico Anápolis-Itauçu.

Sendo os solos do município de Anápolis considerados ácidos e pobres em nutrientes, para torná-los produtivos utilizam-se grandes quantidades de fertilizantes que contém 
compostos de $\mathrm{Ca}, \mathrm{Mg}$, Na e K. Reafirmando a posição de Esteves (1998) apud Petruf, Sacco e Lucio (2011) entre a afinidade da CE e os elementos $\mathrm{Ca}, \mathrm{Mg}, \mathrm{Na}$ e $\mathrm{K}$, os valores desses elementos na presente pesquisa (Figura 14) apresentaram forte correlação com a CE em percentuais que variaram de $89 \%$ a $96 \%$ no período seco e $74 \%$ a $92 \%$ no período chuvoso.

Nos pontos P21 e P22, os teores de Ca não são especificamente atribuídos a fertilizantes, mas às calagens, procedimento agrícola que usa o calcário para reduzir a alta saturação do Al e corrigir o pH do solo (CORRÊA, 2000). Segundo Reimann e Caritat (1998) a alta presença do $\mathrm{Ca}$ em solos dificulta a disponibilidade do $\mathrm{Fe}$ nas águas, nos resultados encontrados para os elementos $\mathrm{Ca}$ e $\mathrm{Fe}$, essa proporção inversa apresenta-se no meio aquático em questão.

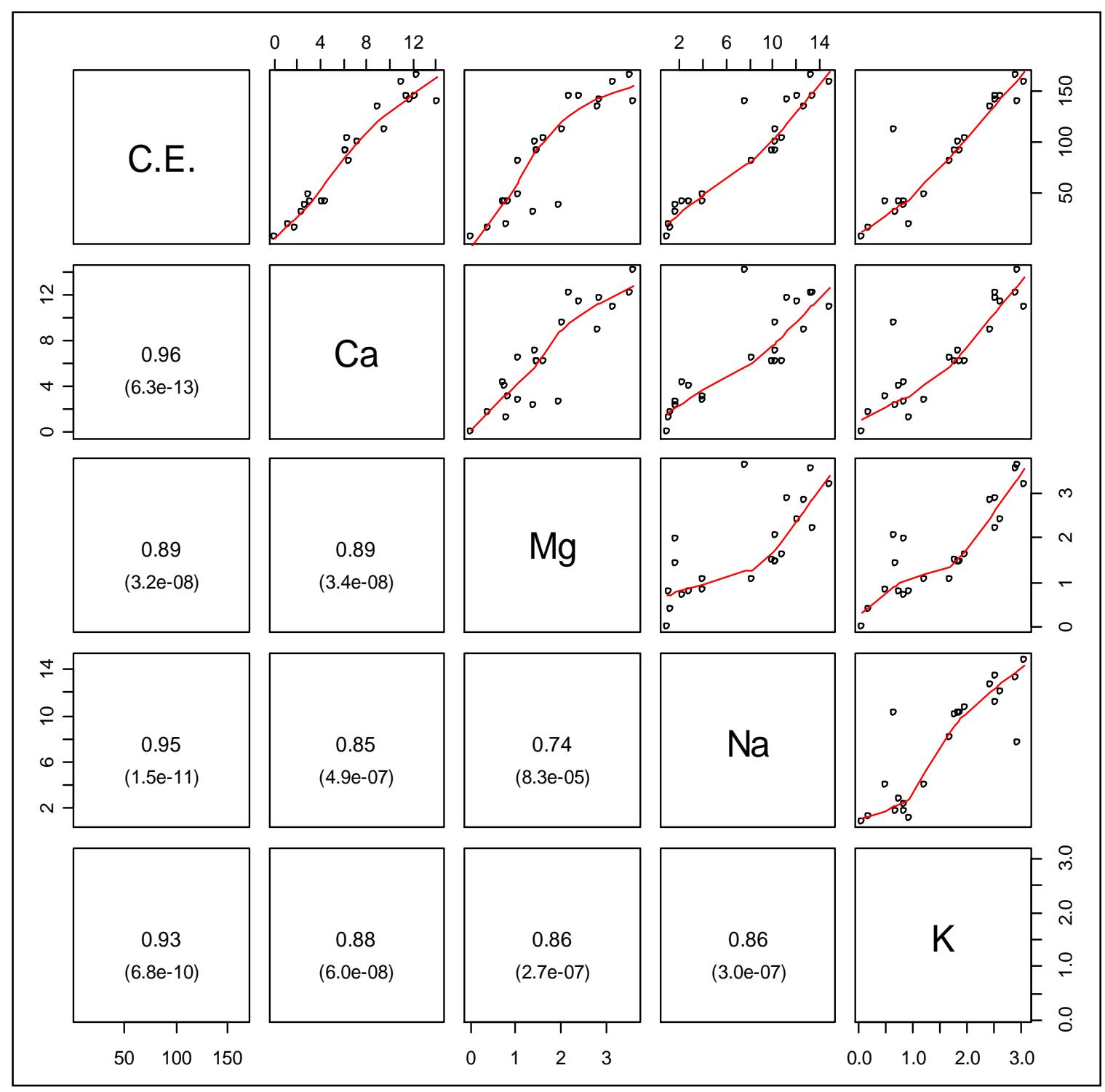

Figura 14 - Matriz Scatterplots entre os parâmetros CE e os elementos Ca, Mg, Na e K no período da Seca. 
Nesse mesmo trecho urbano onde foram encontradas altas concentrações de $\mathrm{Ca}, \mathrm{Mg}$, $\mathrm{Na}$ e $\mathrm{K}$, foram também registrados também altos índices de $\mathrm{Cl}^{-}, \mathrm{NH}_{3}, \mathrm{NO}_{3}{ }^{-}$(Tabela 11), compostos de efluentes enriquecidos com esgoto doméstico despejados no leito do rio sem tratamento prévio. $\mathrm{O} \mathrm{Cl}^{-}$, considerado bom indicador de contaminação das águas por esgoto, sofreu aumento médio em suas concentrações $\left(4,2 \mathrm{mg} \mathrm{L}^{-1}\right.$, período seco e 5,0 $\mathrm{mg} \mathrm{L}^{-1}$, período chuvoso).

Tabela 11- Parâmetros Químicos da água na estação seca e chuvosa

\begin{tabular}{|c|c|c|c|c|c|c|c|c|}
\hline & \multicolumn{2}{|c|}{$\mathrm{Cl}^{-}$} & \multicolumn{2}{|c|}{$\mathrm{NH}_{3}$} & \multicolumn{2}{|c|}{$\mathrm{NO}_{3}{ }^{-}$} & \multicolumn{2}{|c|}{$\mathrm{PO}_{4}{ }^{3-}$} \\
\hline & Seca & Chuva & Seca & Chuva & Seca & Chuva & Seca & Chuva \\
\hline P1 & $<\mathrm{LQ}$ & 0,39 & $<\mathrm{LQ}$ & $<\mathrm{LQ}$ & 0,89 & 0,69 & $<\mathrm{LQ}$ & $<\mathrm{LQ}$ \\
\hline P2 & 0,86 & 1,15 & 0,07 & $<\mathrm{LQ}$ & 1,90 & 1,74 & $<\mathrm{LQ}$ & $<\mathrm{LQ}$ \\
\hline P3 & 1,29 & 1,49 & 0,07 & $<\mathrm{LQ}$ & 0,80 & 2,95 & $<\mathrm{LQ}$ & $<\mathrm{LQ}$ \\
\hline P4 & 4,73 & 1,60 & 0,78 & 0,48 & 6,92 & 2,88 & $<\mathrm{LQ}$ & $<\mathrm{LQ}$ \\
\hline P5 & 4,38 & 6,52 & 1,93 & 0,63 & 2,50 & 15,47 & $<\mathrm{LQ}$ & $<\mathrm{LQ}$ \\
\hline P6 & 8,70 & 8,05 & 1,12 & 1,55 & 15,36 & $\mathbf{5 , 5 9}$ & $<\mathrm{LQ}$ & $<\mathrm{LQ}$ \\
\hline P7 & 10,21 & 9,25 & 2,30 & 2,45 & 12,87 & 9,36 & $<\mathrm{LQ}$ & $<\mathrm{LQ}$ \\
\hline P8 & 9,16 & 5,35 & 1,85 & 1,76 & 13,12 & 11,09 & $<\mathrm{LQ}$ & 0,74 \\
\hline P9 & 7,30 & 9,80 & 1,12 & 2,40 & 12,15 & 10,99 & $<\mathrm{LQ}$ & $<\mathrm{LQ}$ \\
\hline P10 & 3,90 & 4,66 & 0,48 & $<\mathrm{LQ}$ & 12,29 & 14,19 & $<\mathrm{LQ}$ & $<\mathrm{LQ}$ \\
\hline P11 & 7,13 & $\mathbf{9 , 8 9}$ & 0,90 & 1,84 & 14,44 & 10,64 & $<\mathrm{LQ}$ & $<\mathrm{LQ}$ \\
\hline P12 & 0,79 & 2,88 & $<\mathrm{LQ}$ & 1,03 & 0,40 & 1,18 & $<\mathrm{LQ}$ & $<\mathrm{LQ}$ \\
\hline P13 & 5,40 & 9,57 & 0,07 & 1,65 & 18,39 & 10,75 & $<\mathrm{LQ}$ & $<\mathrm{LQ}$ \\
\hline P14 & 8,84 & 6,30 & 0,56 & $<\mathrm{LQ}$ & 11,75 & 17,80 & $<\mathrm{LQ}$ & $<\mathrm{LQ}$ \\
\hline P15 & 2,92 & $\mathbf{9 , 5 3}$ & $<\mathrm{LQ}$ & 1,40 & 2,20 & 10,28 & $<\mathrm{LQ}$ & $<\mathrm{LQ}$ \\
\hline P16 & 0,76 & 8,19 & 0,10 & 1,12 & 1,51 & 9,05 & $<\mathrm{LQ}$ & $<\mathrm{LQ}$ \\
\hline P17 & 4,79 & 0,71 & 1,38 & $<\mathrm{LQ}$ & 2,66 & 0,65 & $<\mathrm{LQ}$ & $<\mathrm{LQ}$ \\
\hline P18 & 2,00 & 5,01 & 0,48 & 1,03 & 1,36 & 9,19 & $<\mathrm{LQ}$ & $<\mathrm{LQ}$ \\
\hline P19 & 0,29 & 0,79 & 0,08 & $<\mathrm{LQ}$ & 0,21 & 0,31 & $<\mathrm{LQ}$ & $<\mathrm{LQ}$ \\
\hline P20 & 1,04 & 0,99 & 0,04 & $<\mathrm{LQ}$ & 1,30 & 1,59 & $<\mathrm{LQ}$ & $<\mathrm{LQ}$ \\
\hline P21 & 3,84 & 4,45 & 0,97 & 0,62 & 2,90 & 8,20 & $<\mathrm{LQ}$ & 0,72 \\
\hline P22 & 4,20 & 5,10 & 1,00 & 0,48 & 3,53 & 13,12 & $<\mathrm{LQ}$ & $<\mathrm{LQ}$ \\
\hline
\end{tabular}

Entre os compostos nitrogenados, $\mathrm{o}^{\mathrm{NO}_{3}}{ }^{-}$mostrou situação de alteração maior em relação à $\mathrm{NH}_{3}$, reafirmando características oxidantes das águas superficiais. Enquanto os resultados para $\mathrm{NH}_{3}$ apresentaram-se baixos, elevaram-se os teores de $\mathrm{NO}_{3}{ }^{-}$sugerindo a este estudo, condições sanitárias inadequadas provenientes de fontes antigas. As maiores concentrações desses compostos ocorreram em valores acima de $5 \mathrm{mg} \mathrm{L^{-1 }}$ acentuando a proposição de que a alteração encontrada emana de esgotos e fertilizantes (HERMES e SILVA, 2004). Valores altos de $\mathrm{NH}_{3}$ em alguns pontos amostrados indicam aporte pontual de efluentes domésticos recentes. 
$\mathrm{O} \mathrm{P}$ na forma de $\mathrm{PO}_{4}{ }^{3-}$, raramente é encontrado em águas superficiais em altas concentrações por ser um composto bem solúvel, situação que se observa no Rio das Antas, apenas dois pontos amostrados acusaram presença de $\mathrm{PO}_{4}{ }^{3-}$ em valores bastante baixos conforme Tabela 12. Segundo Paula Filho, de Moura e Marins (2012) o modo preferencial do $\mathrm{P}$ para transporte aquático são os particulados, assim, a ausência deste elemento em águas, indica que o mesmo esteja sendo retirado da sua forma solúvel por adsorção e aportado nos sedimentos de fundo (PEREIRA, 2004). Em Parnaíba-PI, os autores Paula Filho, de Moura e Marins (2012) encontraram 53\% de concentração de P em sedimentos, no Rio das Antas- GO, o P na forma de $\mathrm{P}_{2} \mathrm{O}_{5}$ resultou aproximadamente a $25 \%$ da composição sedimentar (Figura $15)$.

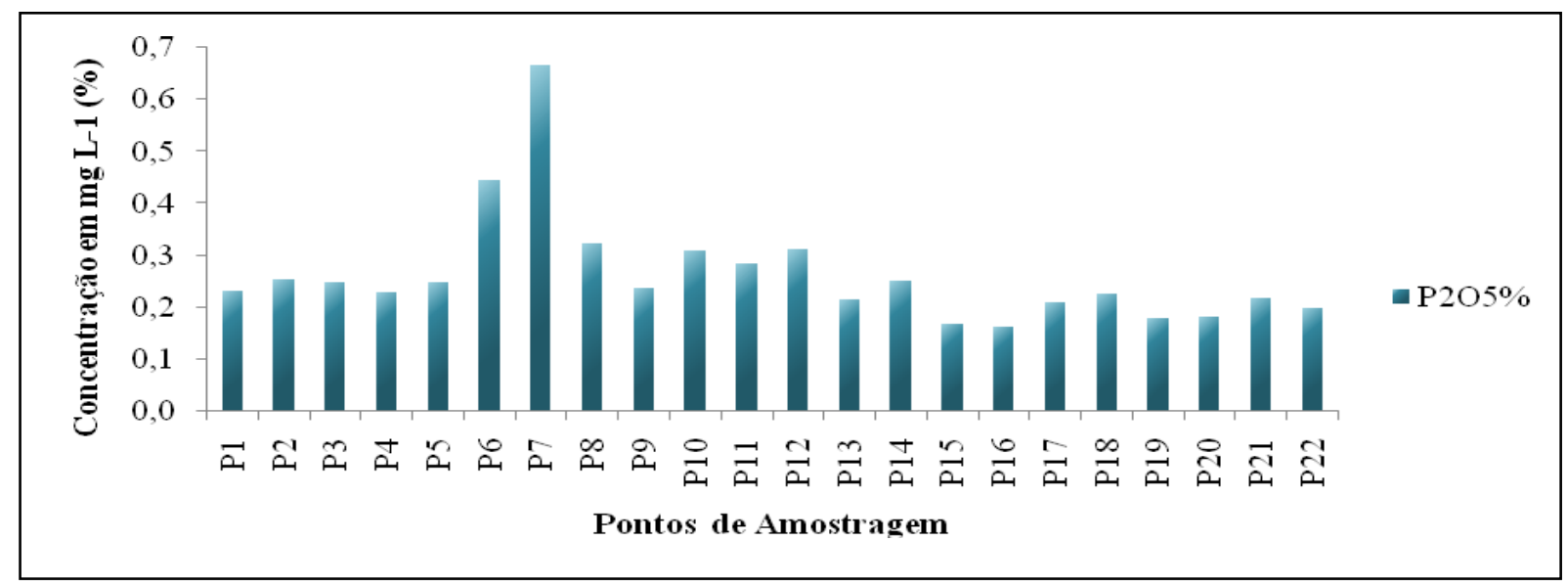

Figura 15- Concentração de $\mathrm{P}_{2} \mathrm{O}_{5}$ em Sedimentos.

A capacidade de adsorção do $\mathrm{P}$ no solo e sedimentos de fundo relaciona-se principalmente com a mineralogia (BAHIA FILHO et al.,1983). Bahia Filho et al, (1983) afirmaram ser a caulinita, gibbsita e material amorfo, os responsáveis pela maior retenção de P. Bigham (1977) atribui ao material de argila goethítico, o principal componente na adsorção máxima dessa espécie química. Bahia Filho et al (1983) mensurou 86\% de adsorção de P em goethita nas observações realizadas em amostras de Latossolos do Planalto Central. Sendo a mineralogia de Anápolis rica desses minerais (Figura 16) subtende-se que $\mathrm{P}$ em quantidade proporcionalmente elevada está em solos sendo disponibilizado aos sedimentos de fundo. 


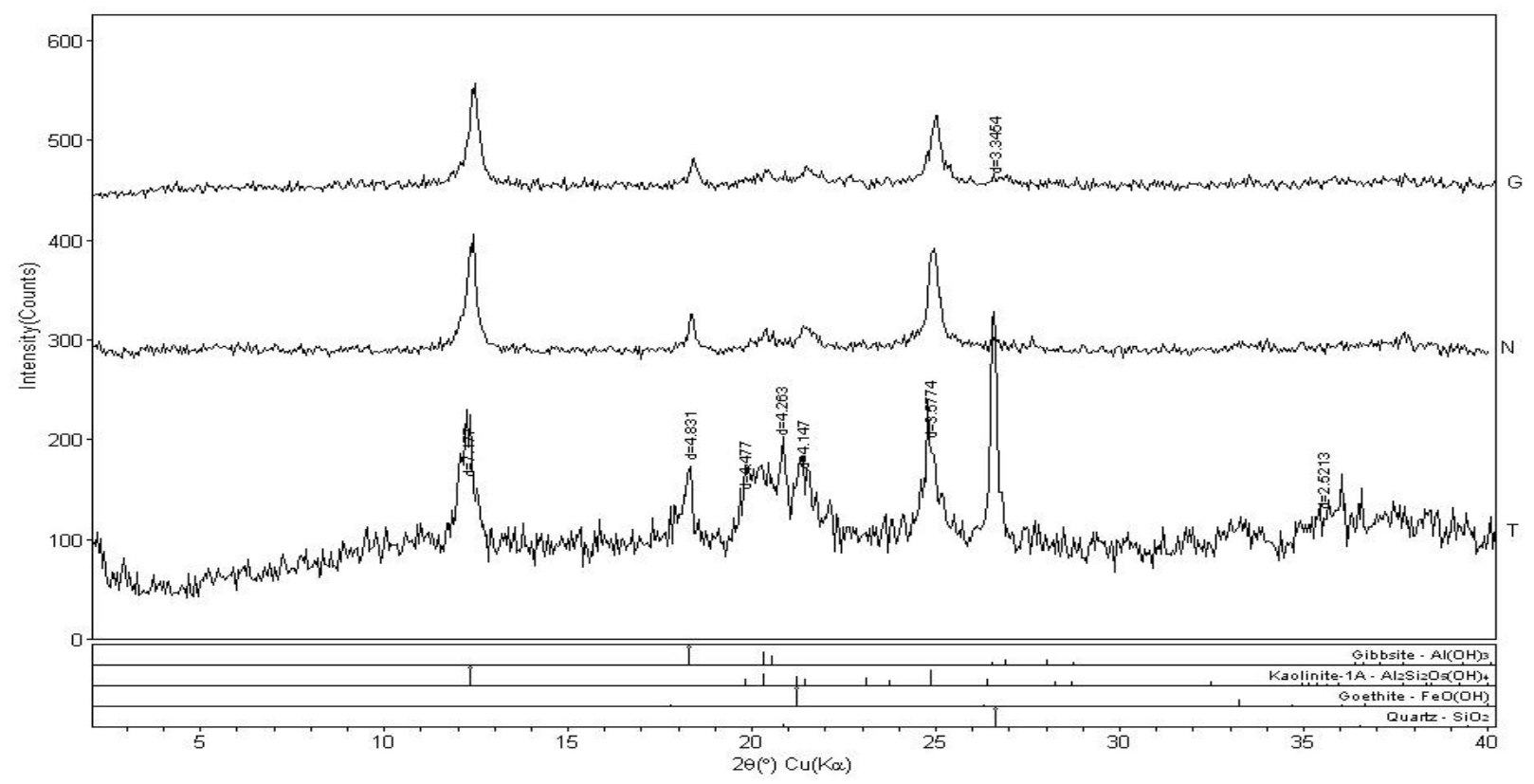

Figura 16- Difratograma de sedimentos de fundo contendo os minerais predominantes da área (Amostra P4).

\subsubsection{Parâmetros Químicos da Água: $\mathrm{SO}_{4}{ }^{2-}$}

$\mathrm{O} \mathrm{SO}_{4}{ }^{2-}$, (Figura 17) apresentou maior concentração no período chuvoso onde a origem está fortemente influenciada pela formação geológica como a oxidação da $\mathrm{FeS}_{2}$ (liberação de $\mathrm{SO}_{4}{ }^{2-}$ e íons $\mathrm{H}^{+}$) e lixiviação de rochas sedimentares incluindo o xisto e composto sulfatado $\mathrm{CaSO}_{4}$ produzindo águas de $\mathrm{pH}$ ácido (LITCH, 1998). À exceção do $\mathrm{P} 1$ (pH= 4,63 estação seca e $\mathrm{pH}=4,93$ estação chuvosa), as amostras estudadas não apresentaram $\mathrm{pH}$ baixos o que sugere neutralização por $\mathrm{HCO}_{3}{ }^{-}$.

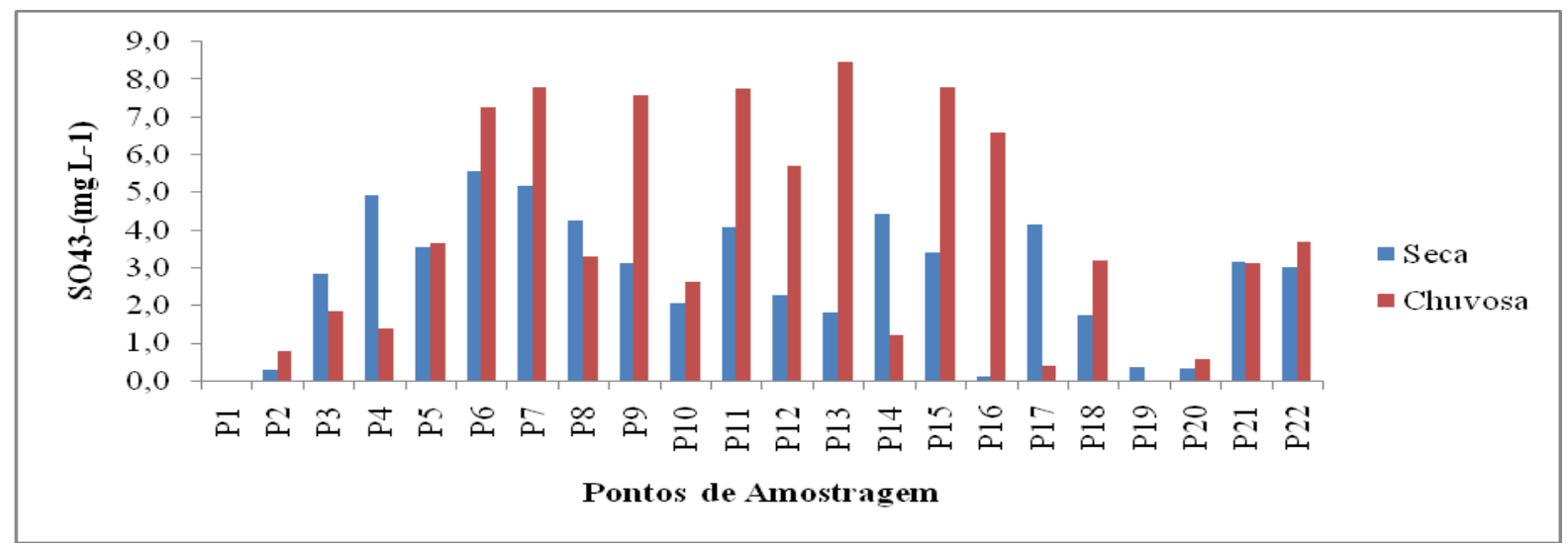

Figura 17- Concentração de $\mathrm{SO}_{4}{ }^{2-}$ em Águas nas duas estações estudadas. 
As determinações de $\mathrm{SO}_{4}{ }^{2-}$ demonstraram altos teores de sais entre os pontos P6 a P16, (estação chuvosa) relacionado à composição geológica e sulfetos dissolvidos na água percolante pela oxidação de matéria orgânica e rejeitos industriais da ETA no tratamento da purificação da água, a qual utiliza sulfato de alumínio. Valores mais baixos (P1, P19 e P20) correspondem a locais onde a concentração de $\mathrm{SO}_{4}{ }^{2-}$ sedimenta-se com o Ca e $\mathrm{Mg}$, presentes na área (Figura 18).

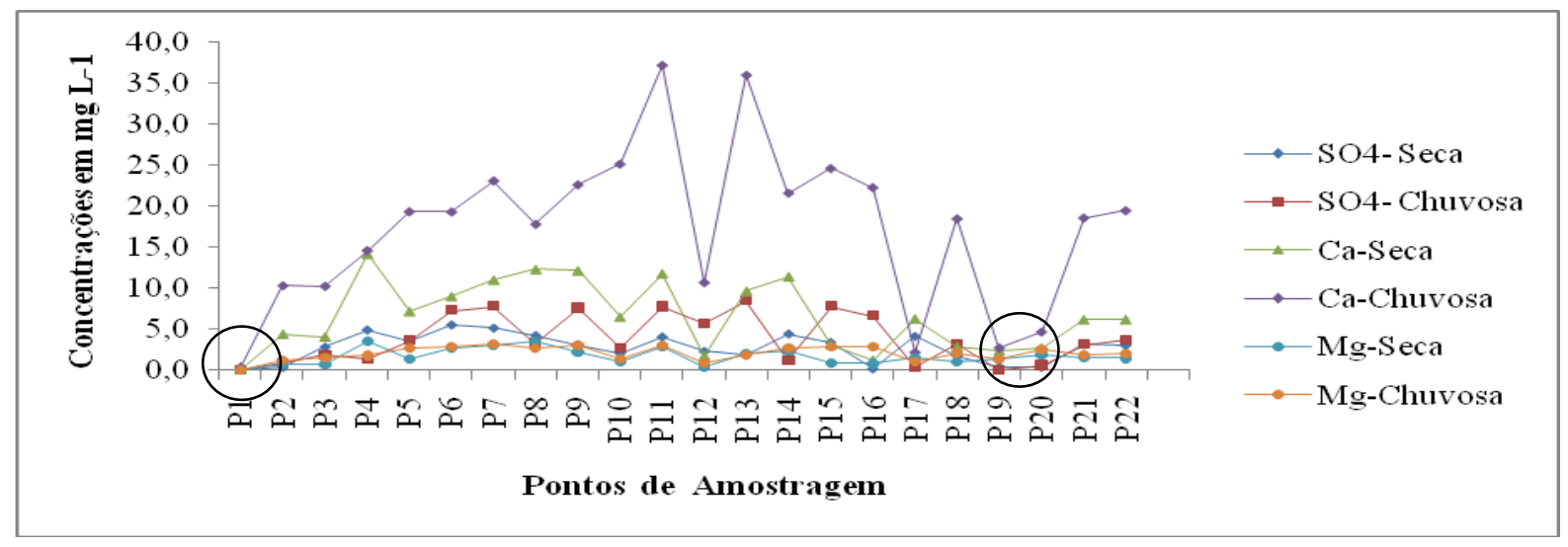

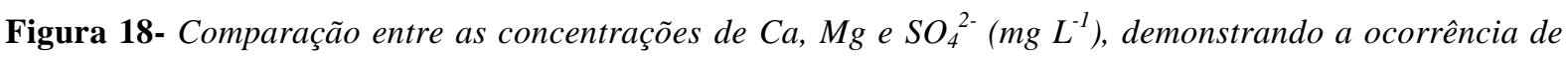
sedimentação nos pontos $\mathrm{P} 19$ e P20.

\subsection{4 pH, $\mathrm{HCO}_{3}^{-}, \mathrm{Fe}$ e Al}

O pH (Figura 19), durante as duas estações (seca e chuvosa) apresentou variação entre 4,6 a 7,4 e média de 6,8 (seca) a 6,9 (chuvosa). No período chuvoso houve um aumento percentual de $50 \%$ em pontos com pH acima de 7. Do universo amostrado (22 em cada período), 59\% obtiveram valores compreendidos entre 6-7, ou seja, águas ligeiramente ácidas tendendo à alcalinidade, $36 \%$ abrangeram valores superiores a 7 caracterizadas como alcalinas e 5\%, estão com pH abaixo de 6, condição ácida. Esses resultados mostraram que as águas da área pesquisada derivam de nascentes, infiltração direta de chuva e recebem influência da composição geológica do solo que são "ácidos e empobrecidos pela lixiviação de bases" (MORAIS JÚNIOR, et al., 2013). Comportamento semelhante foi encontrado por Paula Filho, de Moura e Marins (2012) em Parnaíba-PI, região predominantemente composta por Latossolos onde os valores de $\mathrm{pH}$ se mostraram inferiores a 7, média igual a 6,4 com tendência à acidez, principalmente nas nascentes. 


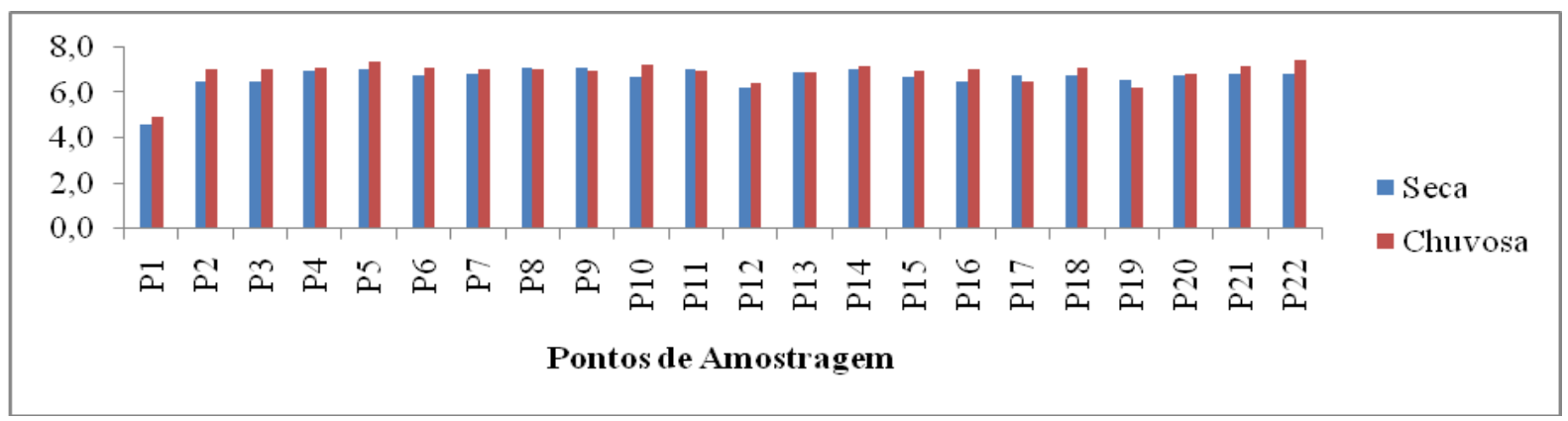

Figura 19- Concentração de pH no Rio das Antas durante a estação seca e chuvosa.

Se comparados ao P1, ponto de background localizado em área de preservação (4,6 seca e 4,9 chuvosa), os resultados demonstraram considerável tamponamento por $\mathrm{HCO}_{3}{ }^{-}$. A presença de $\mathrm{HCO}_{3}{ }^{-}$está diretamente relacionada ao $\mathrm{pH}$ e à quantidade de $\mathrm{CO}_{2}$ nas águas. Reações químicas ocorridas entre água, $\mathrm{HCO}_{3}{ }^{-}$e $\mathrm{CO}_{2}$ geram $\mathrm{H}_{2} \mathrm{CO}_{3}$ que faz o $\mathrm{pH}$ diminuir. A dureza carbonatada indicada pelo grau ou capacidade de tamponamento da água para manter o pH mais estável possível, atua pelo processo de solubilidade ou precipitação de carbonatos. É notável maior quantidade de $\mathrm{HCO}_{3}^{-}$em período chuvoso (Figura 20) influenciando o pH da área estudada, nessa estação há maior introdução de acidez na água por fatores associados à presença de ácidos húmicos livres em solução e elevada concentração de $\mathrm{CO}_{2}$ capturado da atmosfera e dissolvido na água precipitada. A contribuição de águas pluviais no sistema aquático favorece a redução do $\mathrm{pH}$ até o valor de equilíbrio, iniciando o processo de solubilização do $\mathrm{HCO}_{3}{ }^{-}$com disponibilização de íons ao sistema. Cessadas as chuvas, $\mathrm{o} \mathrm{pH}$ se eleva e $\mathrm{O} \mathrm{HCO}_{3}{ }^{-}$retorna à forma precipitada (AZEVEDO; CAMPOS, BOAVENTURA, 2014).

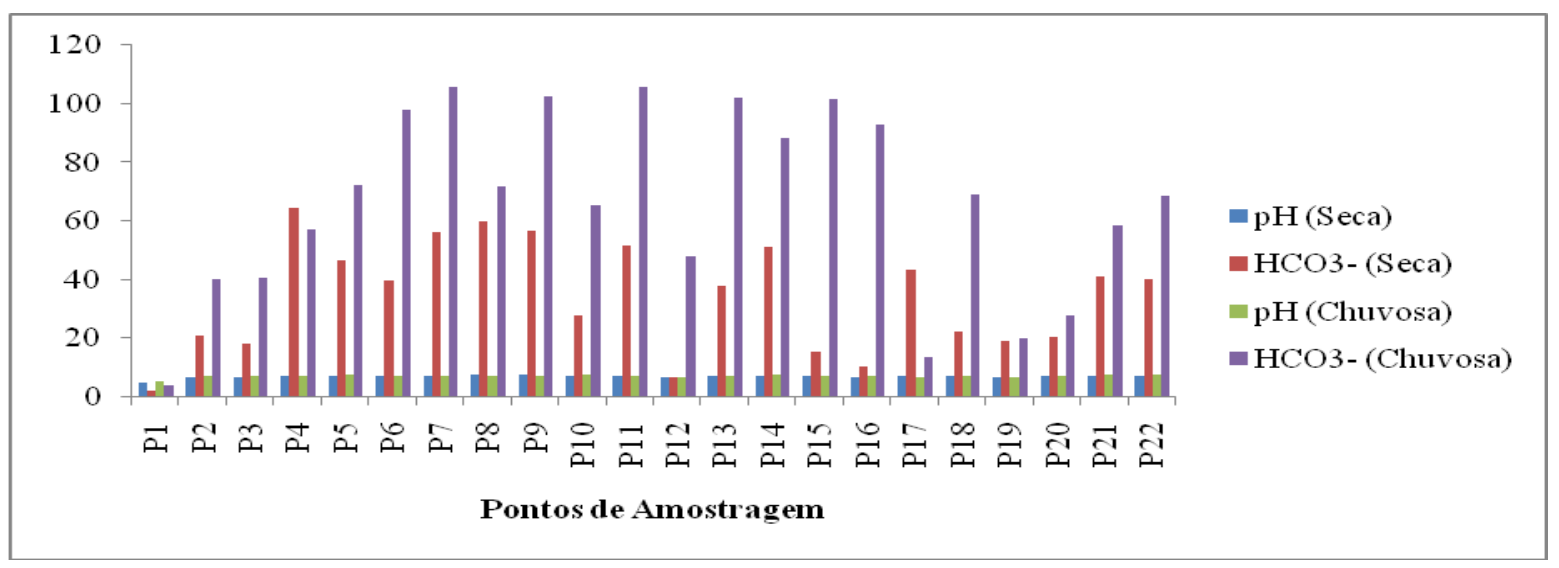

Figura 20- Concentração de $\mathrm{HCO}_{3}{ }^{-}\left(\mathrm{mg} \mathrm{L}^{-1}\right)$ e pH no Rio das Antas durante a estação seca e chuvosa. 
Águas enriquecidas com sais inibem a ação de microorganismos presentes nos processos biológicos, interferem na autodepuração dos cursos d'água e favorecem a precipitação de metais nos sedimentos (GREENBERG et al.,1992). Estes metais poderão ser liberados aos cursos d'água pela mudança de temperatura, potencial de oxi-redução, disponibilidade de ligantes e complexantes. No caso específico do Rio das Antas, o Fe e o Al em água ficaram abaixo do limite de quantificação (LQ) (LQ=0,20 para ambos os metais), mas apresentaram concentrações expressivas nos sedimentos de fundo (Figura 21). Em pH entre 4 e 11,5 como os encontrados nessa pesquisa, o Al geralmente está ligado a hidroxila $\mathrm{Al}(\mathrm{OH})_{3}$, mineral estável que favorece sua ausência no sistema hídrico. Os difratogramas da área (Anexo 6) demonstraram presença marcante da $\mathrm{Al}(\mathrm{OH})_{3}$ e da $\mathrm{FeO}(\mathrm{OH})$, minerais fornecedores de $\mathrm{Al}$ e $\mathrm{Fe}$, típicos de regiões com alto intemperismo e solos lixiviados. Luiz (2012), no estudo realizado em Goiânia-GO, encontrou solos ácidos, com baixos teores de Al propiciando a formação da $\mathrm{Al}(\mathrm{OH})_{3}$.

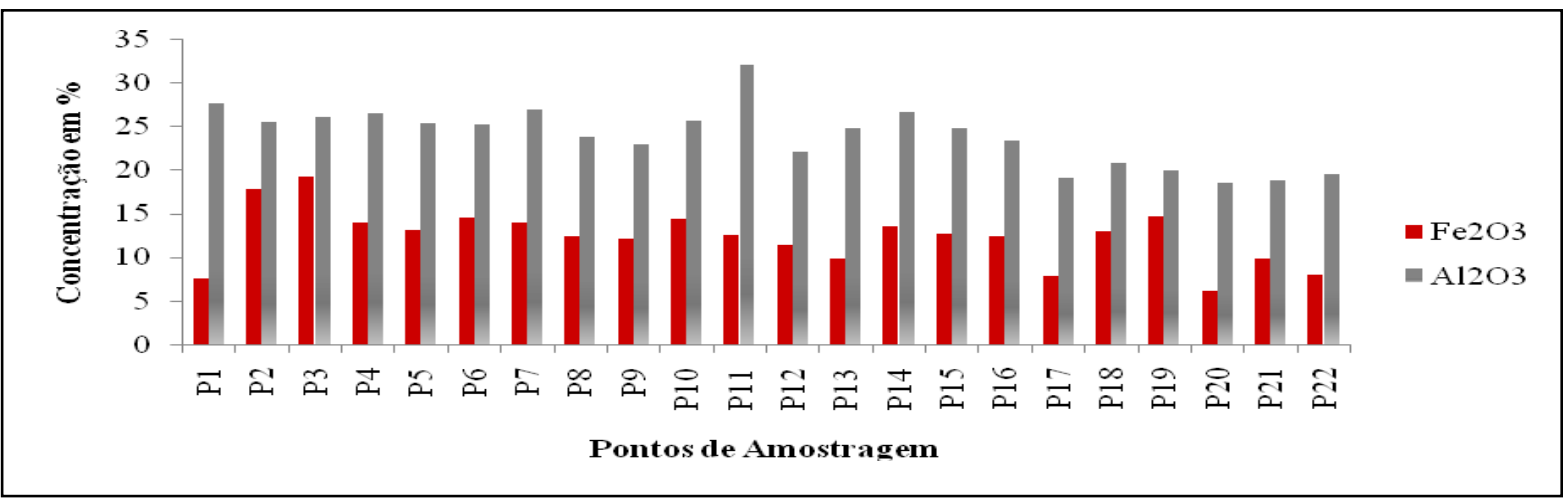

Figura 21- Concentração de $\mathrm{Fe}_{2} \mathrm{O}_{3}$ e $\mathrm{Al}_{2} \mathrm{O}_{3}(\%)$ no sedimento de fundo do Rio das Antas.

\subsubsection{Indicadores Bacteriológicos e correlação com Parâmetros Físico-Químicos da Água}

A Tabela 12 e a Figura 22 apresentam a concentração e a associação existente entre os diversos parâmetros coletados na terceira campanha (10 Pontos) respectivamente. Elevadas quantidades de bactérias coliformes (P6 a P10) correspondem às maiores quantidades encontradas de Escherichia Coli e DBO nas amostras analisadas. Os pontos dessas coletas localizam-se próximos à estação de tratamento de esgoto municipal de Anápolis e aterro sanitário, induzindo à alusão de que há influencia de percolação de efluentes e contaminação do aquífero conforme alerta Carvalho (2011). Quanto à turbidez, cor e pH, concentrações 
maiores situam-se nos pontos P4 e P5 (Bairro São Carlos) local com grande potencial erosivos e constantes assoreamentos.

Tabela 12- Descrição da concentração dos parâmetros microbiológicos e físico-químicos

\begin{tabular}{cccccccc}
\hline Parâmetros & Col. Total & $\boldsymbol{E}$. Coli & OD & DBO & Turbidez & Cor Ap. & pH \\
\hline P1 & $>1,6.10^{3}$ & $9,3.10^{-2}$ & 4,30 & 0,50 & 1,57 & 4,40 & 4,99 \\
P2 & $>1,6.10^{3}$ & $4,9.10^{-1}$ & 6,80 & 1,40 & 14,00 & 48,20 & 6,72 \\
P3 & $>1,6.10^{3}$ & $9,4.10^{-1}$ & 7,00 & 0,70 & 38,10 & 56,40 & 7,13 \\
P4 & $>1,6.10^{3}$ & $>1,6.10^{3}$ & 5,30 & 1,30 & 216,00 & 299,60 & 7,20 \\
P5 & $>1,6.10^{3}$ & $>1,6.10^{3}$ & 5,00 & 0,20 & 340,00 & 913,00 & 7,15 \\
P6 & $2,4.10^{5}$ & $4,9.10^{4}$ & 7,50 & 1,50 & 21,00 & 70,50 & 7,16 \\
P7 & $9,2.10^{5}$ & $2,4.10^{5}$ & 6,90 & 5,60 & 24,30 & 68,30 & 7,06 \\
P8 & $9,4.10^{4}$ & $7,9.10^{4}$ & 7,00 & 6,50 & 21,90 & 71,20 & 7,00 \\
P9 & $9,4.10^{4}$ & $7,9.10^{4}$ & 7,50 & 7,00 & 28,20 & 69,50 & 6,89 \\
P10 & $>1,6.10^{5}$ & $2,2.10^{4}$ & 7,20 & - & 25,00 & 73,00 & 7,00 \\
\hline
\end{tabular}

Nota: Col. Total e E.Coli (N.M.P 100mL), OD e DBO (mg L L), Turbidez (uT), Cor Ap.=Cor Aparente (uH) e pH (não há unidade de medida). N.M.P= número mais provável. - não determinado

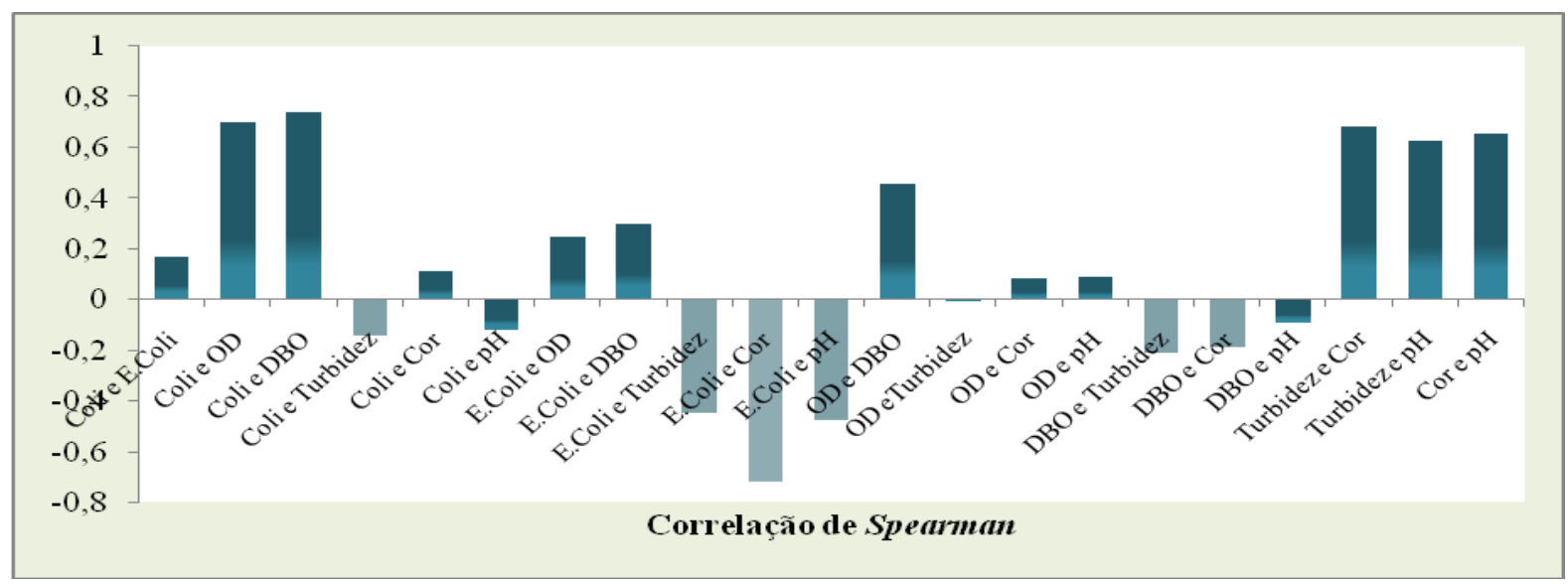

Figura 22- Coeficiente da Correlação de Spearman $(-1<r<1)$ e significância estatística dos parâmetros físico-químicos no Rio das Antas com valores de Coliformes Totais e E. Coli (significativo para $p<0,05$ ) na terceira campanha de coleta (10 Pontos).

Entre os indicadores bacteriológicos e parâmetros físico-químicos da água, seis correlações apresentaram como significativas. Destes, a significância positiva para Coliformes Totais, OD e DBO podem estar associada ao fato de que um elevado número de microorganismos aumenta a quantidade de OD necessária para ocorrer a oxidação da matéria orgânica biodegradável sob condições aeróbicas.

Na correlação de E.Coli e Cor Aparente (inexistência de materiais em suspensão) com significância inversamente proporcional, mostra que a quantidade de sólidos dissolvidos na água (cor real) está favorecendo a proliferação de microorganismos patogênicos. Terra (2010) encontrou também correlação negativa para Coliformes e IQA $(-0,49)$ quando avaliou a qualidade da água do rio Jacu Braço Norte-ES, associando correlação positiva entre 
Coliformes e Sólidos Totais $(0,48)$.

A classificação dos resultados das correlações entre os parâmetros determinados encontram-se na Tabela 13. Segundo Callegari-Jacques (2003, p. 90), o coeficiente ( $\rho$ ) de correlação pode ser avaliado qualitativamente e a interpretação de seu valor depende dos objetivos de utilização e as razões pelas quais estes são calculados. Na correlação deste estudo que analisa a qualidade da água quanto aos agentes biológicos, a maioria dos parâmetros constituiu associações fracas, sendo, correlação linear forte para agentes microbiológicos em $\rho$ valores entre 0,60 a 0,70 .

Tabela 13- Classificação da Correlação Spearman entre Parâmetros Microbiológicos e Físico-Químicos do Rio das Antas - GO

\begin{tabular}{|c|c|c|}
\hline $\begin{array}{c}\text { Correlação Linear } \\
\text { Fraca } \\
\text { se } 0,00<|\rho|<0, \mathbf{3 0}\end{array}$ & $\begin{array}{c}\text { Correlação Linear Moderada } \\
\text { se } 0,30<|\rho|<0,60\end{array}$ & $\begin{array}{c}\text { Correlação Linear Forte } \\
\text { se } 0,60<|\rho|<0,90\end{array}$ \\
\hline Col. e E.Coli & E.Coli e Turbidez & Col. e OD \\
\hline Col. e Turbidez & E.Coli e pH & Col. e DBO \\
\hline Col. e Cor & OD e DBO & E.Coli e Cor \\
\hline Col. e pH & - & Turbidez e Cor \\
\hline E.Coli e OD & - & Turbidez e pH \\
\hline E.Coli e DBO & - & Cor e $\mathrm{pH}$ \\
\hline OD e Turbidez & - & \\
\hline OD e Cor & - & - \\
\hline OD e pH & - & - \\
\hline DBO e Turbidez & - & - \\
\hline DBO e Cor & - & - \\
\hline $\mathrm{DBO}$ e $\mathrm{pH}$ & - & - \\
\hline
\end{tabular}

\subsubsection{Oxigênio Dissolvido (OD) e Demanda Bioquímica de Oxigênio (DBO)}

A entrada anômala de material nas drenagens, difusão pontual de despejos e a atividade microbiana podem ser observadas na associação de concentração dos parâmetros OD e DBO (Figura 23). Percebe-se que para os dois parâmetros estudados, há uma dispersão dos valores de concentração com tendências crescentes à medida que o rio percorre o perímetro urbano, com destaque para o aumento da DBO em áreas agricultáveis, receptoras do efluente da estação de tratamento de esgoto e drenagens do aterro sanitário (P6 a 10). A correlação linear entre essas duas variáveis é considerada moderada $(r=0,457326)$. 
O teor de OD avalia o efeito de despejos oxidáveis no recurso hídrico, serve como indicador das condições de vida na água e para verificar o processo de autodepuração (MACEDO et al, 2005; TUNDISI; TUNDISI, 2008). Quanto maior o grau de poluição (alteração das condições físicas, químicas ou biológicas do recurso hídrico), maior a DBO, assim, pode-se afirmar que o processo de autodepuração do rio esteja sendo comprometido pela entrada de matéria resultante das atividades humanas. Segundo Balls et al. (1996), caso o oxigênio no meio aquático seja totalmente consumido, tem-se condições anaeróbicas e a geração de condições redutoras, aumentando a toxicidade de muitos elementos químicos, que se tornam mais solúveis.

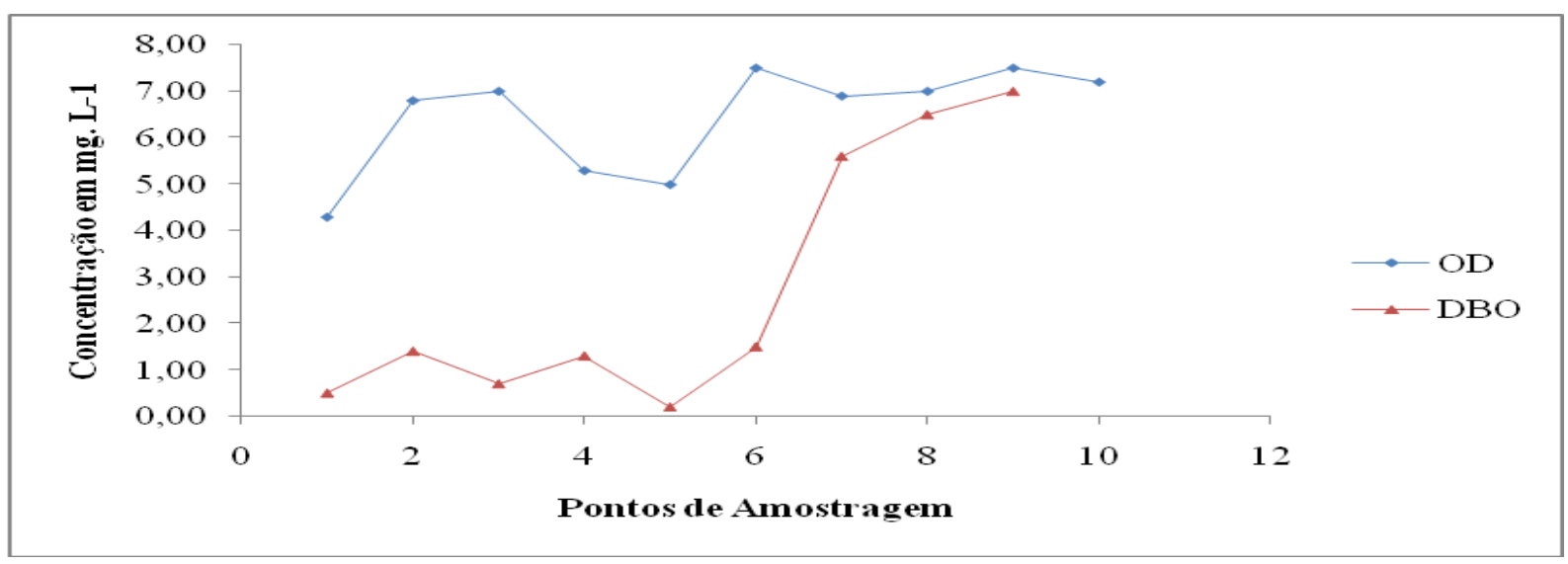

Figura 23- Concentração de $O D$ e $D B O\left(m g L^{-1}\right)$ no Rio das Antas - GO.

\subsubsection{Análise de Sedimentos Matéria Orgânica e Sólidos Voláteis (SV)}

A composição química dos teores médios de sedimentos de fundo do Rio das Antas é rica em $\mathrm{SiO}_{2}, \mathrm{Al}_{2} \mathrm{O}_{3}, \mathrm{Fe}_{2} \mathrm{O}_{3}$ e pobre em $\mathrm{TiO}_{2}, \mathrm{CaO}, \mathrm{Na}_{2} \mathrm{O}, \mathrm{K}_{2} \mathrm{O}$ e $\mathrm{MgO}$ (Tabela 14). Enquanto o $\mathrm{SiO}_{2}$ apresentou aumento de montante a jusante, notou-se situação inversa para $\mathrm{o} \mathrm{Al}_{2} \mathrm{O}_{3} \mathrm{e}$ SV, fato explicado pela remoção de mata ciliar, mata de galeria e impermeabilização do solo que reduz a presença da matéria orgânica e contribui para maior composição de arenitos quartzosos com baixos teores de metais (JESUS et al., 2004). $\mathrm{O} \mathrm{SiO}_{2}$ e o $\mathrm{Al}_{2} \mathrm{O}_{3}$ originam da mesma fonte, a caulinita, $\mathrm{o} \mathrm{Fe}_{2} \mathrm{O}_{3}$ da goethita, ambos presente em todos os pontos amostrados. A caulinita é formada a partir de minerais na gênese de rochas ígneas ou metamórficas, por alteração in situ de feldspatos e de minerais alumino-silicáticos, sua presença em solos fixa nas partículas de argila substâncias húmicas (SGARBI; HORN, 2014). Segundo Lima (2004), solos formados por granitos e gnaisses que originam a caulinita, biotita, ilmenita e outros 
minerais, são profundos (Latossolos), de textura grosseira a média, apresentam considerável teor de cascalhos e possuem coloração vermelho-amarela, peculiaridades registradas por Radaelli (2004) e Jesus (2013) na região de Anápolis. O enriquecimento em caulinita nos sedimentos de fundo também contribuiu para a retirada considerável do Fe e Al no Rio das Antas, pois, nas análises de água, apresentaram quantificações abaixo do limite de detecção.

Tabela 14- Resultados obtidos para Óxidos e Sólidos Voláteis (PC) nos Sedimentos de Fundo

\begin{tabular}{cccccccccccc}
\hline Amostras & $\mathbf{S i O}_{\mathbf{2}}$ & $\mathbf{A l}_{\mathbf{2}} \mathbf{O}_{\mathbf{3}}$ & $\mathbf{F e}_{\mathbf{2}} \mathbf{O}_{\mathbf{3}}$ & $\mathbf{C a O}$ & $\mathbf{M g O}$ & $\mathbf{T i O}_{\mathbf{2}}$ & $\mathbf{N a}_{\mathbf{2}} \mathbf{O}$ & $\mathbf{K}_{\mathbf{2}} \mathbf{O}$ & $\mathbf{P}_{\mathbf{2}} \mathbf{O}_{\mathbf{5}}$ & $\mathbf{P C}$ & $\mathbf{S o m a}$ \\
\hline P1 & 17,1 & 27,5 & 7,5 & 1,0 & 0,01 & 2,9 & 0,5 & 0,1 & 0,2 & 43,2 & 100,0 \\
P2 & 28,3 & 25,2 & 17,8 & 0,6 & 0,3 & 3,1 & 0,7 & 0,2 & 0,3 & 23,5 & 100,0 \\
P3 & 26,1 & 25,9 & 19,3 & 0,7 & 0,1 & 3,3 & 0,6 & 0,3 & 0,2 & 23,7 & 100,2 \\
P4 & 29,9 & 25,0 & 15,0 & 1,2 & 0,2 & 2,0 & 0,8 & 0,3 & 0,2 & 23,4 & 98,0 \\
P5 & 28,7 & 25,4 & 13,2 & 0,9 & 0,3 & 1,9 & 0,7 & 0,4 & 0,2 & 27,2 & 98,9 \\
P6 & 31,0 & 25,3 & 14,6 & 1,8 & 0,8 & 1,8 & 1,1 & 0,5 & 0,4 & 23,6 & 100,9 \\
P7 & 28,7 & 26,0 & 14,0 & 1,2 & 0,4 & 1,7 & 0,9 & 0,4 & 0,7 & 26,1 & 100,1 \\
P8 & 29,4 & 24,8 & 12,4 & 1,5 & 0,6 & 2,6 & 1,0 & 0,8 & 0,3 & 25,9 & 99,3 \\
P9 & 31,4 & 22,9 & 12,2 & 2,4 & 2,5 & 2,5 & 0,8 & 0,5 & 0,2 & 24,2 & 99,6 \\
P10 & 27,7 & 25,7 & 14,5 & 1,4 & 0,6 & 2,8 & 0,8 & 0,4 & 0,3 & 25,5 & 99,7 \\
P11 & 24,3 & 32,1 & 12,5 & 0,7 & 0,2 & 2,4 & 0,6 & 0,3 & 0,3 & 26,6 & 100,0 \\
P12 & 35,8 & 22,2 & 11,5 & 1,4 & 0,8 & 3,9 & 0,9 & 0,8 & 0,3 & 21,5 & 99,1 \\
P13 & 32,4 & 24,8 & 9,8 & 0,7 & 0,1 & 3,6 & 0,7 & 0,3 & 0,2 & 27,3 & 99,9 \\
P14 & 25,1 & 26,7 & 13,5 & 0,6 & 0,1 & 2,1 & 0,6 & 0,2 & 0,3 & 28,9 & 98,1 \\
P15 & 31,3 & 24,8 & 12,7 & 1,5 & 1,0 & 2,0 & 1,0 & 0,5 & 0,2 & 25,0 & 100,0 \\
P16 & 37,9 & 23,4 & 12,4 & 1,2 & 0,7 & 2,4 & 0,8 & 0,5 & 0,2 & 21,3 & 100,8 \\
P17 & 44,9 & 21,1 & 7,9 & 0,7 & 0,4 & 2,5 & 0,8 & 0,8 & 0,2 & 20,1 & 99,4 \\
P18 & 45,1 & 20,2 & 12,0 & 1,1 & 0,5 & 2,4 & 0,5 & 0,4 & 0,2 & 17,5 & 99,9 \\
P19 & 45,6 & 18,7 & 14,2 & 1,3 & 0,7 & 2,3 & 0,5 & 0,7 & 0,2 & 15,4 & 99,6 \\
P20 & 52,9 & 18,5 & 6,1 & 0,8 & 0,5 & 2,7 & 0,8 & 0,6 & 0,2 & 14,8 & 97,9 \\
P21 & 48,2 & 18,9 & 9,8 & 1,0 & 0,7 & 2,2 & 0,6 & 1,1 & 0,2 & 15,8 & 98,5 \\
P22 & 47,8 & 19,9 & 8,7 & 0,9 & 0,6 & 2,8 & 0,7 & 1,0 & 0,2 & 17,3 & 99,9 \\
\hline Nota: Valores calculados em \% para óxidos e PC. Abreviatura: PC= Perda por Calcinação. & & &
\end{tabular}

Os resultados da Tabela 14 apresentaram sequência de origem de solos mais intemperizados no topo em relação à jusante. $\mathrm{O}^{\mathrm{TiO}_{2}}$ presente na região provém de rochas ígneas alteradas pelo intemperismo na forma de Atanásio e Rutilo (difratograma 1, 2, 3, 12 e 13, Anexo 6), certos gnaisses e xistos da formação do Complexo Granulítico Anápolis-Itauçu. As proporções encontradas de $\mathrm{CaO}, \mathrm{Na}_{2} \mathrm{O}, \mathrm{K}_{2} \mathrm{O}$ e $\mathrm{MgO}$ está relacionada com o caráter distrófico dos solos região (pouca saturação em bases), feldspatos plagioclásio (resistentes à degradação química) e rochas calcárias que dispõe de pequenas proporções de $\mathrm{Ca}$ e $\mathrm{Mg}$.

\subsection{Valor de Referência e Índice de Geoacumulação}

A presença de atividades antrópicas na área da pesquisa dificultou o estabelecimento de 
valores de background para o cálculo do $\mathrm{I}_{\text {geo }}$. Destarte, foi definida a coleta realizada no ponto P1 situado à montante do Rio das Antas onde há vegetação preservada e água de nascentes, como Backgroud em valor referência. O valor de background estabelecido foi comparado com estudo realizado na Bacia do Piancó-Anápolis para validação de referência (Tabela 15).

Tabela 15 - Valores de background -Anápolis - GO

\begin{tabular}{c|c|c}
\hline & Bacia do Piancó (*) & Rio das Antas \\
\hline $\mathbf{S i O}_{\mathbf{2}}(\%)$ & 31,9 & 17,1 \\
$\mathbf{A l}_{\mathbf{2}} \mathbf{O}_{\mathbf{3}}(\%)$ & 26,3 & 27,5 \\
$\mathbf{F e}_{\mathbf{2}} \mathbf{O}_{\mathbf{3}}(\%)$ & 9,0 & 7,5 \\
$\mathbf{C a O}(\%)$ & 1,7 & 1,0 \\
$\mathbf{M g O}(\%)$ & $\mathrm{LQ}$ & 0,01 \\
$\mathbf{T i O}(\%)$ & 2,0 & 2,9 \\
$\mathbf{N a}_{\mathbf{2}} \mathbf{O}(\%)$ & 0,6 & 0,5 \\
$\mathbf{K}_{\mathbf{2}} \mathbf{O}(\%)$ & 0,2 & 0,1 \\
$\mathbf{P}_{\mathbf{2}} \mathbf{O}_{\mathbf{5}}(\%)$ & - & 0,2 \\
$\mathbf{C u}(\mathrm{ppm})$ & 121,0 & 47,4 \\
$\mathbf{Z n}(\mathrm{ppm})$ & 25,0 & 32,9 \\
$\mathbf{B a}(\mathrm{ppm})$ & 58,0 & 21,1 \\
$\mathbf{V}(\mathrm{ppm})$ & 186,0 & 317,1 \\
$\mathbf{S r}(\mathrm{ppm})$ & 26,0 & 3,4 \\
$\mathbf{C o}(\mathrm{ppm})$ & 11,0 & 3,2 \\
$\mathbf{C r}(\mathrm{ppm})$ & 167,0 & 75,6 \\
$\mathbf{M n}(\mathrm{ppm})$ & 22,0 & 55,8 \\
$\mathbf{N i}(\mathrm{ppm})$ & 12,0 & 11,0 \\
\hline
\end{tabular}

(*) BORGES (2009); Os valores de elementos maiores da pesquisa de Borges (2009) foram convertidos para óxidos; - não determinado; LQ= Limite de Quantificação

A partir do valor background calculou-se o índice de geoacumulação em cada amostra coletada de sedimentos de fundo. Por este índice (Tabela 10) é possível notar a complexidade e o grau da intensidade de contaminação a qual o sistema hídrico se encontra. A Tabela 16 classifica os pontos amostrados conforme $\mathrm{I}_{\text {geo }}$ obtido para cada óxido e elemento. 
Tabela 16 - Classificação das amostras de acordo com o índice de geocumulação

\begin{tabular}{|c|c|c|c|c|c|c|c|}
\hline \multirow[b]{2}{*}{ Amostra } & \multicolumn{7}{|c|}{ Índice de Geoacumulação } \\
\hline & 0 & 1 & 2 & 3 & 4 & 5 & 6 \\
\hline P1 & $\begin{array}{c}\mathrm{SiO}_{2}, \mathrm{Al}_{2} \mathrm{O}_{3}, \mathrm{Fe}_{2} \mathrm{O}_{3}, \mathrm{CaO}, \\
\mathrm{MgO}, \mathrm{TiO}_{2}, \mathrm{Na}_{2} \mathrm{O}, \mathrm{K}_{2} \mathrm{O} \\
\mathrm{Sr}, \mathrm{Ba}, \mathrm{V}, \mathrm{Cr}, \mathrm{Mn}, \mathrm{Co}, \mathrm{Ni}, \\
\mathrm{Cu}, \mathrm{Zn}, \mathrm{P}_{2} \mathrm{O}_{5}\end{array}$ & & & & & & \\
\hline $\mathbf{P 2}$ & $\begin{array}{c}\mathrm{Al}_{2} \mathrm{O}_{3}, \mathrm{CaO}, \mathrm{TiO}_{2}, \mathrm{Na}_{2} \mathrm{O} \\
\mathrm{K}_{2} \mathrm{O}, \mathrm{V}, \mathrm{Cr}, \mathrm{P}_{2} \mathrm{O}_{5}\end{array}$ & $\mathrm{SiO}_{2}, \mathrm{Fe}_{2} \mathrm{O}_{3}, \mathrm{Cu}$ & $\mathrm{Sr}, \mathrm{Ni}, \mathrm{Zn}$ & $\mathrm{Ba}$ & $\mathrm{Co}$ & $\begin{array}{c}\mathrm{MgO}, \\
\mathrm{Mn}\end{array}$ & \\
\hline $\mathbf{P 3}$ & $\begin{array}{c}\mathrm{Al}_{2} \mathrm{O}_{3}, \mathrm{CaO}, \mathrm{TiO}_{2}, \mathrm{Na}_{2} \mathrm{O} \\
\mathrm{K}_{2} \mathrm{O}, \mathrm{V}, \mathrm{P}_{2} \mathrm{O}_{5}\end{array}$ & $\mathrm{SiO}_{2}, \mathrm{Fe}_{2} \mathrm{O}_{3}, \mathrm{Sr}, \mathrm{Cr}$ & $\begin{array}{l}\mathrm{Ba}, \mathrm{Ni}, \mathrm{Cu}, \\
\mathrm{Zn}\end{array}$ & $\mathrm{Mn}, \mathrm{Co}$ & $\mathrm{MgO}$ & & \\
\hline P4 & $\begin{array}{c}\mathrm{Al}_{2} \mathrm{O}_{3}, \mathrm{CaO}, \mathrm{TiO}_{2}, \mathrm{Na}_{2} \mathrm{O} \\
\mathrm{K}_{2} \mathrm{O}, \mathrm{V}, \mathrm{Cr}, \mathrm{Cu}, \mathrm{P}_{2} \mathrm{O}_{5}\end{array}$ & $\mathrm{SiO}_{2}, \mathrm{Fe}_{2} \mathrm{O}_{3}, \mathrm{Zn}$ & $\begin{array}{l}\mathrm{Sr}, \mathrm{Ba}, \mathrm{Co}, \\
\mathrm{Ni}\end{array}$ & $\mathrm{Mn}$ & $\mathrm{MgO}$ & & \\
\hline P5 & $\begin{array}{c}\mathrm{Al}_{2} \mathrm{O}_{3}, \mathrm{CaO}, \mathrm{TiO}_{2}, \mathrm{Na}_{2} \mathrm{O} \\
\mathrm{K}_{2} \mathrm{O}, \mathrm{V}, \mathrm{P}_{2} \mathrm{O}_{5}\end{array}$ & $\mathrm{SiO}_{2}, \mathrm{Fe}_{2} \mathrm{O}_{3}, \mathrm{Sr}, \mathrm{Cr}, \mathrm{Cu}$ & $\mathrm{Ni}, \mathrm{Zn}$ & $\begin{array}{c}\mathrm{Ba}, \mathrm{Mn}, \\
\mathrm{Co}\end{array}$ & & $\mathrm{MgO}$ & \\
\hline P6 & $\mathrm{Al}_{2} \mathrm{O}_{3}, \mathrm{TiO}_{2}, \mathrm{~K}_{2} \mathrm{O}, \mathrm{V}$ & $\begin{array}{c}\mathrm{SiO}_{2}, \mathrm{Fe}_{2} \mathrm{O}_{3}, \mathrm{CaO}, \mathrm{Na}_{2} \mathrm{O}, \\
\mathrm{Cr}, \mathrm{P}_{2} \mathrm{O}_{5}\end{array}$ & $\mathrm{Ni}, \mathrm{Cu}$ & $\begin{array}{l}\mathrm{Sr}, \mathrm{Ba}, \\
\mathrm{Co}, \mathrm{Zn}\end{array}$ & $\mathrm{Mn}$ & & $\mathrm{MgO}$ \\
\hline P7 & $\mathrm{Al}_{2} \mathrm{O}_{3}, \underset{V}{\mathrm{CaO}}, \mathrm{TiO}_{2}, \mathrm{~K}_{2} \mathrm{O}$, & $\mathrm{SiO}_{2}, \mathrm{Fe}_{2} \mathrm{O}_{3}, \mathrm{Na}_{2} \mathrm{O}, \mathrm{Cr}$ & $\begin{array}{c}\mathrm{Ni}, \mathrm{Cu} \\
\mathrm{P}_{2} \mathrm{O}_{5}\end{array}$ & $\begin{array}{l}\mathrm{Sr}, \mathrm{Ba}, \\
\mathrm{Co}, \mathrm{Zn}\end{array}$ & $\mathrm{Mn}$ & $\mathrm{MgO}$ & \\
\hline P8 & $\mathrm{Al}_{2} \mathrm{O}_{3}, \mathrm{~K}_{2} \mathrm{O}, \mathrm{V}$ & $\begin{array}{c}\mathrm{SiO}_{2}, \mathrm{Fe}_{2} \mathrm{O}_{3}, \mathrm{CaO}, \mathrm{TiO}_{2} \\
\mathrm{Na}_{2} \mathrm{O}, \mathrm{Cr}, \mathrm{Cu}, \mathrm{P}_{2} \mathrm{O}_{5}\end{array}$ & $\mathrm{Sr}$, , Ni, Zn & $\begin{array}{l}\mathrm{Ba}, \mathrm{Mn}, \\
\mathrm{Co}\end{array}$ & & & $\mathrm{MgO}$ \\
\hline P9 & $\begin{array}{c}\mathrm{Al}_{2} \mathrm{O}_{3}, \mathrm{Na}_{2} \mathrm{O}, \mathrm{K}_{2} \mathrm{O}, \mathrm{V} \\
\mathrm{P}_{2} \mathrm{O}_{5}\end{array}$ & $\begin{array}{c}\mathrm{SiO}_{2}, \mathrm{Fe}_{2} \mathrm{O}_{3}, \mathrm{CaO}, \mathrm{TiO}_{2}, \\
\mathrm{Cr}, \mathrm{Cu}\end{array}$ & $\mathrm{Sr}, \mathrm{Zn}$ & $\begin{array}{l}\mathrm{Ba}, \mathrm{Ni}, \\
\mathrm{Mn}, \mathrm{Co}\end{array}$ & & & $\mathrm{MgO}$ \\
\hline P10 & $\begin{array}{c}\mathrm{Al}_{2} \mathrm{O}_{3}, \mathrm{CaO}, \mathrm{Na}_{2} \mathrm{O}, \mathrm{K}_{2} \mathrm{O}, \\
\mathrm{V}, \mathrm{P}_{2} \mathrm{O}_{5}\end{array}$ & $\begin{array}{c}\mathrm{SiO}_{2}, \mathrm{Fe}_{2} \mathrm{O}_{3}, \mathrm{TiO}_{2}, \mathrm{Cr} \\
\mathrm{Cu}\end{array}$ & $\mathrm{Sr}, \mathrm{Ba}, \mathrm{Zn}$ & $\begin{array}{l}\mathrm{Ni}, \mathrm{Mn}, \\
\mathrm{Co}\end{array}$ & & & $\mathrm{MgO}$ \\
\hline P11 & $\begin{array}{c}\mathrm{SiO}_{2}, \mathrm{Al}_{2} \mathrm{O}_{3}, \mathrm{CaO}, \mathrm{TiO}_{2} \\
\mathrm{Na}_{2} \mathrm{O}, \mathrm{K}_{2} \mathrm{O}, \mathrm{Sr}, \mathrm{V}, \mathrm{Cr} \\
\mathrm{P}_{2} \mathrm{O}_{5} \\
\end{array}$ & $\mathrm{Fe}_{2} \mathrm{O}_{3}, \mathrm{Ba}, \mathrm{Ni}, \mathrm{Cu}, \mathrm{Zn}$ & $\mathrm{Mn}, \mathrm{Co}$ & & $\mathrm{MgO}$ & & \\
\hline P12 & $\begin{array}{c}\mathrm{Al}_{2} \mathrm{O}_{3}, \mathrm{CaO}, \mathrm{TiO}_{2}, \mathrm{~K}_{2} \mathrm{O} \\
\mathrm{V},\end{array}$ & $\begin{array}{c}\mathrm{SiO}_{2}, \mathrm{Fe}_{2} \mathrm{O}_{3}, \mathrm{Na}_{2} \mathrm{O}, \mathrm{Cr} \\
\mathrm{Cu}, \mathrm{P}_{2} \mathrm{O}_{5}\end{array}$ & $\mathrm{Sr}, \mathrm{Ni}, \mathrm{Zn}$ & $\mathrm{Ba}, \mathrm{Co}$ & $\mathrm{Mn}$ & & $\mathrm{MgO}$ \\
\hline P13 & $\begin{array}{c}\mathrm{Al}_{2} \mathrm{O}_{3}, \mathrm{Fe}_{2} \mathrm{O}_{3}, \mathrm{CaO}, \mathrm{TiO}_{2}, \\
\mathrm{Na}_{2} \mathrm{O}, \mathrm{K}_{2} \mathrm{O}, \mathrm{V}, \mathrm{P}_{2} \mathrm{O}_{5}\end{array}$ & $\begin{array}{c}\mathrm{SiO}_{2}, \mathrm{Sr}, \mathrm{Ba}, \mathrm{Cr}, \mathrm{Mn}, \mathrm{Co}, \\
\mathrm{Cu}, \mathrm{Zn}\end{array}$ & $\mathrm{Ni}$ & $\mathrm{MgO}$ & & & \\
\hline P14 & $\begin{array}{c}\mathrm{SiO}_{2}, \mathrm{Al}_{2} \mathrm{O}_{3}, \mathrm{CaO}, \mathrm{TiO}_{2} \\
\mathrm{Na}_{2} \mathrm{O}, \mathrm{K}_{2} \mathrm{O}, \mathrm{Sr}, \mathrm{V}, \mathrm{Mo} \\
\mathrm{P}_{2} \mathrm{O}_{5}\end{array}$ & $\mathrm{Fe}_{2} \mathrm{O}_{3}, \mathrm{Ba}, \mathrm{Cr}, \mathrm{Ni}, \mathrm{Cu}, \mathrm{Zn}$ & $\mathrm{Mn}$ & Co & $\mathrm{MgO}$ & & \\
\hline P15 & $\mathrm{Al}_{2} \mathrm{O}_{3}, \mathrm{TiO}_{2}, \mathrm{~K}_{2} \mathrm{O}, \mathrm{V}$ & $\begin{array}{c}\mathrm{SiO}_{2}, \mathrm{Fe}_{2} \mathrm{O}_{3}, \mathrm{CaO}, \mathrm{Na}_{2} \mathrm{O}, \\
\mathrm{Cr}, \mathrm{Cu}, \mathrm{P}_{2} \mathrm{O}_{5}\end{array}$ & $\mathrm{Sr}, \mathrm{Ni}, \mathrm{Zn}$ & $\begin{array}{c}\mathrm{Ba}, \mathrm{Mn}, \\
\mathrm{Co}\end{array}$ & & & $\mathrm{MgO}$ \\
\hline P16 & $\begin{array}{c}\mathrm{Al}_{2} \mathrm{O}_{3}, \mathrm{CaO}, \mathrm{TiO}_{2}, \mathrm{Na}_{2} \mathrm{O} \\
\mathrm{K}_{2} \mathrm{O}, \mathrm{V}, \mathrm{Cu}, \mathrm{P}_{2} \mathrm{O}_{5}\end{array}$ & $\mathrm{SiO}_{2}, \mathrm{Fe}_{2} \mathrm{O}_{3}, \mathrm{Sr}, \mathrm{Cr}, \mathrm{Zn}$ & $\mathrm{Ni}$ & $\begin{array}{l}\mathrm{Ba}, \mathrm{Mn}, \\
\mathrm{Co}\end{array}$ & & & $\mathrm{MgO}$ \\
\hline P17 & $\begin{array}{c}\mathrm{Al}_{2} \mathrm{O}_{3}, \mathrm{Fe}_{2} \mathrm{O}_{3}, \mathrm{CaO}, \mathrm{TiO}_{2}, \\
\mathrm{Na}_{2} \mathrm{O}, \mathrm{K}_{2} \mathrm{O}, \mathrm{Sr}, \mathrm{V}, \mathrm{Cr}, \mathrm{Cu}, \\
\mathrm{P}_{2} \mathrm{O}_{5}\end{array}$ & $\mathrm{SiO}_{2}, \mathrm{Ni}$ & Co, $\mathrm{Zn}$ & $\mathrm{Ba}, \mathrm{Mn}$ & & $\mathrm{MgO}$ & \\
\hline P18 & $\begin{array}{c}\mathrm{Al}_{2} \mathrm{O}_{3}, \mathrm{CaO}, \mathrm{Na}_{2} \mathrm{O}, \mathrm{K}_{2} \mathrm{O} \\
\mathrm{V}, \mathrm{Cu}, \mathrm{P}_{2} \mathrm{O}_{5}\end{array}$ & $\mathrm{SiO}_{2}, \mathrm{Fe}_{2} \mathrm{O}_{3}, \mathrm{TiO}_{2}, \mathrm{Cr}, \mathrm{Zn}$ & $\begin{array}{c}\mathrm{Sr}, \mathrm{Ba}, \mathrm{Mn}, \\
\mathrm{Co}, \mathrm{Ni}\end{array}$ & & & & $\mathrm{MgO}$ \\
\hline P19 & $\begin{array}{c}\mathrm{Al}_{2} \mathrm{O}_{3}, \mathrm{CaO}, \mathrm{Na}_{2} \mathrm{O}, \mathrm{K}_{2} \mathrm{O} \\
\mathrm{V}, \mathrm{Cu}\end{array}$ & $\begin{array}{c}\mathrm{Fe}_{2} \mathrm{O}_{3}, \mathrm{TiO}_{2}, \mathrm{Sr}, \mathrm{Cr}, \mathrm{Zn}, \\
\mathrm{P}_{2} \mathrm{O}_{5}\end{array}$ & $\mathrm{Ba}, \mathrm{Ni}$ & $\mathrm{Mn}, \mathrm{Co}$ & & & $\mathrm{MgO}$ \\
\hline $\mathbf{P 2 0}$ & $\begin{array}{c}\mathrm{Al}_{2} \mathrm{O}_{3}, \mathrm{Fe}_{2} \mathrm{O}_{3}, \mathrm{CaO}, \mathrm{Na}_{2} \mathrm{O}, \\
\mathrm{K}_{2} \mathrm{O}, \mathrm{V}, \mathrm{Cu}, \mathrm{P}_{2} \mathrm{O}_{5}\end{array}$ & $\begin{array}{c}\mathrm{SiO}_{2}, \mathrm{TiO}_{2}, \mathrm{Sr}, \mathrm{Cr}, \mathrm{Mn}, \\
\mathrm{Zn}\end{array}$ & $\mathrm{Ba}, \mathrm{Co}, \mathrm{Ni}$ & & $\mathrm{MgO}$ & & \\
\hline $\mathbf{P 2 1}$ & $\begin{array}{c}\mathrm{Al}_{2} \mathrm{O}_{3}, \mathrm{Fe}_{2} \mathrm{O}_{3}, \mathrm{CaO}, \mathrm{TiO}_{2}, \\
\mathrm{Na}_{2} \mathrm{O}, \mathrm{Sr}, \mathrm{V}, \mathrm{P}_{2} \mathrm{O}_{5}\end{array}$ & $\mathrm{SiO}_{2}, \mathrm{~K}_{2} \mathrm{O}, \mathrm{Cr}, \mathrm{Cu}, \mathrm{Zn}$ & $\mathrm{Ba}, \mathrm{Ni}$ & $\mathrm{Mn}, \mathrm{Co}$ & & & $\mathrm{MgO}$ \\
\hline $\mathbf{P 2 2}$ & $\begin{array}{c}\mathrm{Al}_{2} \mathrm{O}_{3}, \mathrm{Fe}_{2} \mathrm{O}_{3}, \mathrm{CaO}, \mathrm{TiO}_{2}, \\
\mathrm{Na}_{2} \mathrm{O}, \mathrm{V}, \mathrm{Cu}, \mathrm{P}_{2} \mathrm{O}_{5}\end{array}$ & $\mathrm{SiO}_{2}, \mathrm{~K}_{2} \mathrm{O}, \mathrm{Cr}, \mathrm{Zn}$ & $\begin{array}{l}\mathrm{Sr}, \mathrm{Ba}, \mathrm{Co}, \\
\mathrm{Ni}\end{array}$ & $\mathrm{Mn}$ & & & $\mathrm{MgO}$ \\
\hline
\end{tabular}

Os resultados indicam estágios avançados de acumulação por compostos e elementos em toda extensão da pesquisa com destaque para o $\mathrm{MgO}, \mathrm{Mn}$, Co e $\mathrm{Ba}$ cujos valores se encontram "forte a extremamente enriquecidos", nível 3 a 6. A acumulação dos metais Mn, Co e Ba evidencia a dissolução de rochas carbonáticas pelo aumento de $\mathrm{MgO}$ e diminuição 
da concentração de $\mathrm{CaO}, \mathrm{Na}_{2} \mathrm{O}, \mathrm{K}_{2} \mathrm{O}$, logo eleva-se as concentrações de minerais menos solúveis e dos elementos a eles associados ( $\mathrm{Mn}$, Co e $\mathrm{Ba}$ ). A porcentagem de $\mathrm{MgO}$ nos sedimentos foi uma das menores, no entanto, por ser um óxido higroscópico, sua geoacumulação se encontra superior aos demais óxidos e elementos determinados. Sabe-se que, os valores médios de Co nos diferentes tipos de rochas variam bastante, em granitos e arenitos seus níveis são tipicamente baixos (REIMANN e CARITAT, 1998), no entanto, este elemento possui uma barreira geoquímica que é adsorção, explicando seus altos teores encontrados nos sedimentos de fundo. O estudo na bacia do Piancó-Anápolis, realizado por Borges (2009) constatou elevados índices de geoacumulação para Mg e Co considerando-o como "moderadamente alterado".

Nos níveis 1 e 2 "acumulação moderada" estão $\mathrm{SiO}_{2}, \mathrm{Fe}_{2} \mathrm{O}_{3}, \mathrm{Cu}, \mathrm{Ni}, \mathrm{Zn}, \mathrm{Sr}$, e Cr. A acumulação do $\mathrm{SiO}_{2}, \mathrm{Fe}_{2} \mathrm{O}_{3}$ demonstram origem associada a silicatos de ferro e alumínio, como os argilominerais. $\mathrm{O} \mathrm{Cu}$ e o $\mathrm{Zn}$, embora tenha origem geológica, seu aumento pode estar relacionado à decomposição da matéria orgânica depositada em solo hidromórfico vindo de plantações, hortaliças e outras lavouras. A maioria dos óxidos e elementos classificados como "ausência" de acumulação são provenientes de ação redox do meio e composição geológica. A classificação referência para os sedimentos do Rio das Antas por faixa de concentração, a partir da formulação de índices de geoacumulação e valores de background se encontra na Tabela 17. Considerando os resultados obtidos, os valores de referência definidos para esta pesquisa poderão ser aplicados em outros rios situados na região de Anápolis ou locais geologicamente semelhantes. 
Tabela 17- Referência Geoquímica para as concentrações de sedimentos de fundo no Rio das Antas Anápolis-GO.

\begin{tabular}{ccccccccc}
\hline & $\begin{array}{c}\text { Média de } \\
\text { background }\end{array}$ & $\mathbf{0}$ & $\mathbf{1}$ & $\mathbf{2}$ & $\mathbf{3}$ & $\mathbf{4}$ & $\mathbf{5}$ & $\mathbf{6}$ \\
\hline $\mathbf{S i O}_{\mathbf{2}}(\%)$ & 17,13 & $\leq 25$ & $26-51$ & $52-103$ & $104-206$ & $207-411$ & $412-822$ & $823-1645$ \\
$\mathbf{A l}_{\mathbf{2}} \mathbf{O}_{\mathbf{3}}(\%)$ & 27,74 & $\leq 41$ & $42-83$ & $84-166$ & $167-333$ & $334-666$ & $667-1331$ & $1332-2663$ \\
$\mathbf{F e}_{\mathbf{2}} \mathbf{O}_{\mathbf{3}}(\%)$ & 7,54 & $\leq 11$ & $12-23$ & $24-45$ & $46-91$ & $92-181$ & $182-362$ & $363-724$ \\
$\mathbf{C a O}(\%)$ & 0,96 & $\leq 1$ & $2-3$ & $4-6$ & $7-12$ & $13-23$ & $24-46$ & $47-92$ \\
$\mathbf{M g O}(\%)$ & 0,01 & $\leq 0,02$ & $0,02-0,03$ & $0,04-0,06$ & $0,07-0,11$ & $0,12-0,23$ & $0,24-0,47$ & $0,48-0,96$ \\
$\mathbf{T i O}(\%)$ & 2,31 & $\leq 3$ & $4-7$ & $8-14$ & $15-28$ & $29-55$ & $56-111$ & $112-222$ \\
$\mathbf{N a}_{\mathbf{2}} \mathbf{O}(\%)$ & 0,59 & $\leq 0,89$ & $1-2$ & $3-4$ & $5-7$ & $8-14$ & $15-28$ & $29-57$ \\
$\mathbf{K}_{\mathbf{2}} \mathbf{O}(\%)$ & 0,07 & $\leq 0,11$ & $0,12-0,21$ & $0,22-0,42$ & $0,43-0,86$ & $0,87-1,72$ & $1,73-3,46$ & $3,47-6,94$ \\
$\mathbf{P}_{\mathbf{2}} \mathbf{O}_{\mathbf{5}}(\%)$ & 0,2 & $\leq 0,3$ & $0,4-0,6$ & $0,7-1,2$ & $1,3-2,4$ & $2,5-4,8$ & $4,9-9,6$ & $9,7-19,2$ \\
$\mathbf{C u}(\mathrm{ppm})$ & 47,40 & $\leq 71$ & $72-142$ & $143-284$ & $285-569$ & $570-1138$ & $1139-2275$ & $2276-4550$ \\
$\mathbf{Z n}(\mathrm{ppm})$ & 32,90 & $\leq 49$ & $50-99$ & $100-197$ & $198-395$ & $396-790$ & $791-1579$ & $1580-3158$ \\
$\mathbf{B a}(\mathrm{ppm})$ & 21,10 & $\leq 31$ & $32-63$ & $64-127$ & $128-253$ & $254-506$ & 5071013 & $1014-2026$ \\
$\mathbf{V}(\mathrm{ppm})$ & 317,10 & $\leq 475$ & $476-951$ & $952-1903$ & $1904-3805$ & $3806-7610$ & $7611-15221$ & $15222-30442$ \\
$\mathbf{S r}(\mathrm{ppm})$ & 3,40 & $\leq 5$ & $6-10$ & $11-20$ & $21-41$ & $42-82$ & $83-163$ & $164-326$ \\
$\mathbf{C o}(\mathrm{ppm})$ & 3,20 & $\leq 4$ & $5-10$ & $11-19$ & $20-38$ & $39-77$ & $78-154$ & $155-307$ \\
$\mathbf{C r}(\mathrm{ppm})$ & 75,60 & $\leq 113$ & $114-227$ & $228-454$ & $455-907$ & $908-1814$ & $1815-3629$ & $3630-7258$ \\
$\mathbf{M n}(\mathrm{ppm})$ & 55,80 & $\leq 83$ & $84-167$ & $168-335$ & $336-670$ & $671-1339$ & $1340-2678$ & $2679-5357$ \\
$\mathbf{N i}(\mathrm{ppm})$ & 11,00 & $\leq 16$ & $17-33$ & $34-66$ & $67-132$ & $133-264$ & $265-528$ & $529-1056$ \\
\hline
\end{tabular}

\subsection{Correlação de Spearman - Parâmetros Físico-Químicos da Água e Sedimentos de Fundo}

As correlações simultâneas encontradas nas épocas de seca e chuva estão destacadas em vermelho na matriz de correlação de água e de azul na matriz correlação de sedimento de fundo (Tabela 18, 19 e 20 respectivamente). Os elementos $\mathrm{Cu}, \mathrm{Zn}, \mathrm{Ba}, \mathrm{Cr}$ e o parâmetro $\mathrm{CE}$, não apresentaram correlação com a matéria orgânica, demonstrando origem geológica. $\mathrm{O} \mathrm{Cr}$ (140 mg/g) obteve concentração abaixo do valor de background encontrado na bacia do Piancó (167 mg/g) sendo considerado para este estudo no Antas, um fator de acumulação "moderado". Apesar dos elementos $\mathrm{Cu}, \mathrm{Zn}, \mathrm{Ba}$ e $\mathrm{Cr}$ refletirem a composição geológica, o excesso em alguns pontos (P6 a P10, P12 e P15), indica incidência de efluentes industriais, urbanos e agrícolas que colaboram para o aumento percentual em suas concentrações. Conforme Campos et al. (2005), é importante avaliar o potencial de riscos ocasionados pelo uso abusivo de fertilizantes ou outras fontes de metais. Fertilizantes agroquimicos fosfatados possuem concentrações superiores de $\mathrm{Cr}, \mathrm{Cu}, \mathrm{Ni}$ e $\mathrm{Zn}$, nos termofosfatados e $\mathrm{Cu}, \mathrm{Ni}$ e $\mathrm{Zn}$ nos fosfatos naturais. A correlação do $\operatorname{Sr}$ x Ba $(0,78)$ pode ser explicada pela origem mineralógica de ambos (rochas sulfatadas) e pelo valor do raio iônico do cátion Ba ser semelhante ao elemento Sr oxidado, ocorrendo na natureza substituições em carbonatos sedimentares. 
Tabela 18- Correlação de Spearman na época seca. Os valores em vermelho apresentam correlação na época seca e chuvosa. Os valores em negrito apresentam correlação apenas na seca. $\mathrm{R} \geq 50 \%$

\begin{tabular}{|c|c|c|c|c|c|c|c|c|c|c|c|c|c|c|c|c|c|c|c|}
\hline \multicolumn{20}{|c|}{ Matriz de Correlação: Spearman } \\
\hline Seca & pH & C.E. & $\mathrm{Ca}$ & Mg & $\mathrm{Na}$ & $\mathbf{K}$ & $\mathrm{NH}_{3}$ & $\mathbf{F}^{-}$ & $\mathrm{Cl}^{-}$ & $\mathrm{NO}_{3}^{-}$ & $\mathrm{SO}_{4}{ }^{2-}$ & $\mathrm{HCO}_{3}^{-}$ & $\mathrm{Fe}$ & $\mathbf{S i}$ & Al & Turb. & $\mathrm{CO}_{2}$ & TDS & Temp \\
\hline pH & 1 & & & & & & & & & & & & & & & & & & \\
\hline C.E. & 0,89 & 1 & & & & & & & & & & & & & & & & & \\
\hline $\mathrm{Ca}$ & 0,86 & 0,95 & 1 & & & & & & & & & & & & & & & & \\
\hline Mg & 0,82 & 0,88 & 0,85 & 1 & & & & & & & & & & & & & & & \\
\hline $\mathrm{Na}$ & 0,81 & 0,95 & 0,85 & 0,79 & 1 & & & & & & & & & & & & & & \\
\hline $\mathbf{K}$ & 0,75 & 0,87 & 0,83 & 0,84 & 0,81 & 1 & & & & & & & & & & & & & \\
\hline $\mathrm{NH}_{3}$ & 0,72 & 0,78 & 0,68 & 0,67 & 0,82 & 0,86 & 1 & & & & & & & & & & & & \\
\hline $\mathbf{F}^{-}$ & 0,46 & 0,66 & 0,61 & 0,71 & 0,67 & 0,67 & 0,59 & 1 & & & & & & & & & & & \\
\hline Cl- & 0,82 & 0,98 & 0,91 & 0,85 & 0,96 & 0,82 & 0,75 & 0,69 & 1 & & & & & & & & & & \\
\hline $\mathrm{NO}_{3}{ }^{-}$ & 0,70 & 0,85 & 0,84 & 0,75 & 0,83 & 0,66 & 0,59 & 0,73 & 0,87 & 1 & & & & & & & & & \\
\hline $\mathrm{SO}_{4}^{2-}$ & 0,63 & 0,81 & 0,77 & 0,75 & 0,79 & 0,78 & 0,70 & 0,66 & 0,84 & 0,62 & 1 & & & & & & & & \\
\hline $\mathrm{HCO}_{3}^{-}$ & 0,91 & 0,93 & 0,93 & 0,88 & 0,85 & 0,92 & $\mathbf{0 , 8 3}$ & 0,62 & 0,86 & 0,72 & 0,75 & 1 & & & & & & & \\
\hline $\mathbf{F e}$ & $-0,16$ & $-0,26$ & $-0,38$ & $-0,22$ & $-0,20$ & $-0,25$ & $-0,22$ & $-0,22$ & $-0,26$ & $-0,35$ & $-0,19$ & $-0,28$ & 1 & & & & & & \\
\hline $\mathbf{S i}$ & 0,47 & 0,44 & 0,31 & 0,64 & 0,47 & $\mathbf{0 , 5 1}$ & $\mathbf{0 , 5 2}$ & 0,37 & 0,44 & 0,21 & 0,42 & 0,46 & 0,12 & 1 & & & & & \\
\hline Al & $-0,22$ & $-0,40$ & $-0,50$ & $-0,28$ & $-0,37$ & $-0,38$ & $-0,34$ & $-0,33$ & $-0,38$ & $-0,40$ & $-0,35$ & $-0,40$ & 0,76 & 0,20 & 1 & & & & \\
\hline Turb. & 0,06 & 0,13 & 0,07 & 0,18 & 0,15 & 0,22 & 0,35 & 0,01 & 0,16 & $-0,11$ & 0,52 & 0,15 & 0,05 & 0,26 & $-0,01$ & 1 & & & \\
\hline $\mathrm{CO}_{2}$ & $-0,16$ & 0,07 & 0,02 & 0,07 & 0,16 & 0,20 & 0,25 & 0,43 & 0,07 & 0,05 & 0,19 & 0,11 & $-0,23$ & $-0,03$ & $-0,47$ & 0,14 & 1 & & \\
\hline TDS & $\mathbf{0 , 8 9}$ & 1,00 & 0,95 & 0,88 & 0,95 & 0,87 & 0,78 & 0,66 & 0,98 & 0,85 & 0,81 & 0,94 & $-0,27$ & 0,44 & $-0,40$ & 0,12 & 0,07 & 1 & \\
\hline Temp. & 0,50 & 0,56 & 0,65 & 0,41 & 0,43 & 0,47 & 0,31 & 0,25 & 0,53 & 0,46 & 0,50 & 0,51 & $-0,66$ & 0,01 & $-0,50$ & 0,04 & $-0,11$ & 0,56 & 1 \\
\hline
\end{tabular}


Tabela 19- Correlação de Spearman na época chuvosa. Os valores em vermelho apresentam correlação na época seca e chuvosa. Os valores em negrito apresentam correlação apenas na época Chuvosa. $\mathrm{R} \geq 50 \%$

\begin{tabular}{|c|c|c|c|c|c|c|c|c|c|c|c|c|c|c|c|c|c|c|c|}
\hline \multicolumn{20}{|c|}{ Matriz de Correlação: Spearman } \\
\hline Chuva & pH & C.E. & Ca & $\mathrm{Mg}$ & $\mathrm{Na}$ & $\mathbf{K}$ & $\mathrm{NH}_{3}$ & $\mathbf{F}^{-}$ & $\mathrm{Cl}^{-}$ & $\mathrm{NO}_{3}{ }^{-}$ & $\mathrm{SO}_{4}{ }^{2-}$ & $\mathrm{HCO}_{3}^{-}$ & $\mathbf{F e}$ & Si & Al & Turb. & $\mathrm{CO}_{2}$ & TDS & Temp \\
\hline $\mathrm{pH}$ & 1 & & & & & & & & & & & & & & & & & & \\
\hline C.E. & 0,30 & 1 & & & & & & & & & & & & & & & & & \\
\hline $\mathbf{C a}$ & 0,36 & 0,91 & 1 & & & & & & & & & & & & & & & & \\
\hline Mg & 0,28 & 0,81 & 0,66 & 1 & & & & & & & & & & & & & & & \\
\hline $\mathrm{Na}$ & 0,21 & 0,75 & $\mathbf{0 , 5 3}$ & 0,66 & 1 & & & & & & & & & & & & & & \\
\hline $\mathbf{K}$ & 0,23 & 0,90 & 0,81 & 0,66 & 0,78 & 1 & & & & & & & & & & & & & \\
\hline $\mathbf{N H}_{3}$ & 0,05 & $\mathbf{0 , 8 3}$ & 0,63 & 0,67 & 0,68 & $\mathbf{0 , 8 0}$ & 1 & & & & & & & & & & & & \\
\hline $\mathbf{F}^{-}$ & 0,16 & 0,74 & 0,66 & 0,52 & 0,53 & 0,75 & 0,76 & 1 & & & & & & & & & & & \\
\hline $\mathrm{Cl}^{-}$ & 0,26 & 0,99 & 0,91 & 0,82 & 0,73 & 0,87 & 0,84 & 0,74 & 1 & & & & & & & & & & \\
\hline $\mathrm{NO}_{3}^{-}$ & 0,67 & 0,71 & 0,77 & 0,62 & 0,45 & 0,55 & 0,38 & 0,38 & 0,71 & 1 & & & & & & & & & \\
\hline $\mathrm{SO}_{4}{ }^{2-}$ & 0,14 & 0,89 & 0,81 & 0,61 & 0,71 & 0,87 & 0,89 & 0,81 & 0,91 & 0,51 & 1 & & & & & & & & \\
\hline $\mathrm{HCO}_{3}^{-}$ & 0,29 & 1,00 & 0,89 & 0,81 & 0,74 & 0,87 & 0,85 & 0,75 & 0,98 & 0,69 & 0,89 & 1 & & & & & & & \\
\hline $\mathbf{F e}$ & $-0,27$ & $-0,19$ & $-0,26$ & $-0,02$ & 0,15 & $-0,19$ & 0,10 & $-0,19$ & $-0,16$ & $-0,34$ & $-0,02$ & $-0,17$ & 1 & & & & & & \\
\hline $\mathbf{S i}$ & $-0,04$ & 0,29 & 0,13 & 0,50 & 0,33 & 0,29 & 0,40 & 0,19 & 0,30 & 0,15 & 0,29 & 0,29 & 0,56 & 1 & & & & & \\
\hline Al & $-0,01$ & 0,31 & 0,15 & 0,47 & 0,26 & 0,26 & 0,50 & 0,26 & 0,36 & 0,15 & 0,38 & 0,33 & 0,62 & 0,64 & 1 & & & & \\
\hline Turb. & 0,21 & 0,61 & 0,45 & 0,64 & 0,46 & 0,61 & 0,72 & 0,62 & 0,65 & 0,39 & 0,66 & 0,61 & 0,32 & 0,61 & 0,66 & 1 & & & \\
\hline $\mathrm{CO}_{2}$ & $-0,35$ & 0,30 & 0,03 & 0,23 & 0,32 & 0,29 & 0,58 & 0,52 & 0,30 & $-0,10$ & 0,36 & 0,33 & 0,01 & 0,06 & 0,06 & 0,30 & 1 & & \\
\hline TDS & 0,28 & 1,00 & 0,91 & 0,81 & 0,75 & 0,90 & 0,83 & 0,74 & 0,99 & $\mathbf{0 , 7 0}$ & 0,90 & 0,99 & $-0,19$ & 0,29 & 0,31 & 0,61 & 0,31 & 1 & \\
\hline Temp. & 0,52 & 0,59 & 0,46 & 0,53 & 0,59 & 0,56 & 0,37 & 0,17 & 0,52 & 0,61 & 0,35 & 0,58 & $-0,35$ & 0,11 & 0,01 & 0,24 & 0,05 & 0,57 & 1 \\
\hline
\end{tabular}


Tabela 20- Correlação de Spearman sedimentos de fundo. Os valores em azul apresentam correlação em que R $\geq 50 \%$.

\begin{tabular}{|c|c|c|c|c|c|c|c|c|c|c|c|c|c|c|c|c|c|c|c|}
\hline \multicolumn{20}{|c|}{ Matriz de Correlação: Spearman } \\
\hline & $\mathrm{SiO}_{2}$ & $\mathrm{Al}_{2} \mathrm{O}_{3}$ & $\mathrm{Fe}_{2} \mathrm{O}_{3}$ & $\mathrm{CaO}$ & $\mathrm{MgO}$ & $\mathrm{TiO}_{2}$ & $\mathrm{Na}_{2} \mathrm{O}$ & $\mathrm{K}_{2} \mathrm{O}$ & $P_{2} O_{5}$ & $S r$ & $B a$ & $V$ & $\mathrm{Cr}$ & $M n$ & Co & $\mathrm{Ni}$ & $\mathrm{Cu}$ & $Z n$ & $P F$ \\
\hline $\mathrm{SiO}_{2}$ & 1 & & & & & & & & & & & & & & & & & & \\
\hline $\mathrm{Al}_{2} \mathrm{O}_{3}$ & $-0,96$ & 1 & & & & & & & & & & & & & & & & & \\
\hline $\mathrm{Fe}_{2} \mathrm{O}_{3}$ & $-0,51$ & 0,48 & 1 & & & & & & & & & & & & & & & & \\
\hline $\mathrm{CaO}$ & 0,18 & $-0,19$ & 0,10 & 1 & & & & & & & & & & & & & & & \\
\hline MgO & 0,55 & $-0,56$ & $-0,07$ & 0,77 & 1 & & & & & & & & & & & & & & \\
\hline $\mathrm{TiO}_{2}$ & 0,00 & $-0,12$ & $-0,31$ & $-0,27$ & $-0,19$ & 1 & & & & & & & & & & & & & \\
\hline $\mathrm{Na}_{2} \mathrm{O}$ & 0,09 & $-0,04$ & 0,10 & 0,57 & 0,52 & $-0,18$ & 1 & & & & & & & & & & & & \\
\hline $\mathrm{K}_{2} \mathrm{O}$ & 0,77 & $-0,77$ & $-0,41$ & 0,42 & 0,74 & $-0,05$ & 0,36 & 1 & & & & & & & & & & & \\
\hline $\mathbf{P}_{2} \mathbf{O}_{5}$ & $-0,47$ & $\mathbf{0 , 5 0}$ & 0,41 & 0,13 & 0,03 & $-0,13$ & 0,40 & $-0,15$ & 1 & & & & & & & & & & \\
\hline $\mathbf{S r}$ & $-0,02$ & 0,01 & 0,41 & 0,58 & 0,50 & $-0,11$ & 0,69 & 0,12 & 0,51 & 1 & & & & & & & & & \\
\hline $\mathbf{B a}$ & 0,19 & $-0,23$ & 0,17 & 0,47 & 0,59 & $-0,15$ & 0,68 & 0,38 & 0,34 & 0,78 & 1 & & & & & & & & \\
\hline $\mathbf{V}$ & $-0,77$ & 0,82 & 0,34 & 0,05 & $-0,37$ & 0,04 & 0,06 & $-0,63$ & 0,49 & 0,13 & $-0,24$ & 1 & & & & & & & \\
\hline $\mathrm{Cr}$ & $-0,07$ & 0,02 & 0,22 & 0,24 & 0,19 & 0,09 & 0,08 & 0,00 & $-0,07$ & 0,13 & 0,07 & 0,25 & 1 & & & & & & \\
\hline Mn & 0,06 & $-0,08$ & 0,36 & 0,45 & 0,59 & $-0,18$ & 0,54 & 0,38 & 0,47 & 0,69 & 0,81 & $-0,15$ & 0,06 & 1 & & & & & \\
\hline Co & $-0,18$ & 0,11 & 0,47 & 0,34 & 0,46 & $-0,09$ & 0,41 & 0,10 & 0,54 & 0,62 & 0,63 & 0,05 & 0,42 & 0,76 & 1 & & & & \\
\hline $\mathbf{N i}$ & 0,07 & $-0,14$ & 0,19 & 0,52 & 0,47 & 0,11 & 0,35 & 0,19 & 0,08 & 0,59 & 0,56 & 0,13 & 0,73 & 0,47 & $\mathbf{0 , 5 8}$ & 1 & & & \\
\hline $\mathrm{Cu}$ & $-0,55$ & 0,58 & 0,61 & 0,27 & 0,05 & $-0,19$ & 0,41 & $-0,17$ & 0,69 & 0,45 & 0,29 & 0,66 & 0,37 & 0,51 & 0,54 & 0,42 & 1 & & \\
\hline $\mathbf{Z n}$ & $-0,12$ & 0,13 & 0,34 & 0,52 & 0,47 & $-0,13$ & 0,71 & 0,27 & 0,51 & 0,69 & 0,73 & 0,25 & 0,27 & 0,71 & 0,57 & 0,58 & 0,71 & 1 & \\
\hline PF & $-0,83$ & 0,85 & 0,19 & $-0,10$ & $-0,49$ & $-0,04$ & 0,01 & $-0,66$ & 0,35 & $-0,05$ & $-0,18$ & 0,82 & 0,24 & $-0,14$ & 0,08 & 0,05 & 0,51 & 0,16 & 1 \\
\hline
\end{tabular}




\subsection{Análise de Agrupamento Hierárquico (Cluster Analysis)}

As correlações positivas de Spearman $\geq 50 \%$ da água nos dois períodos (seco e chuvoso) e sedimento de fundo deram origem ao agrupamento hierárquico abrangendo a similaridade e o comportamento geoquímico dos óxidos e elementos maiores e traço na área de pesquisa (Figura 24).

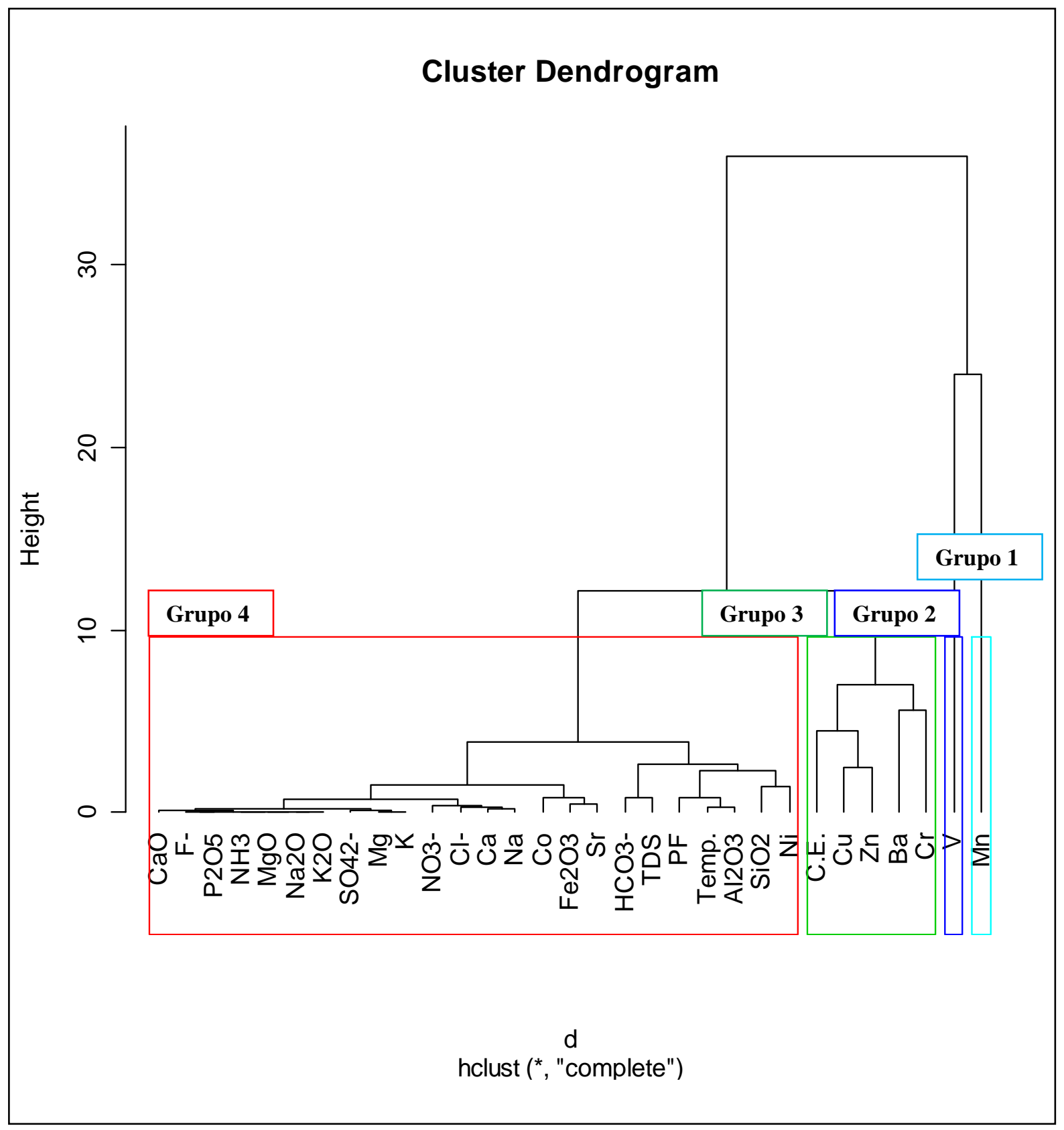

Figura 24- Dendograma de Cluster das análises de água no período seco e chuvoso e dos sedimentos de fundo do Rio das Antas. 
Os grupos 1 e 2 indicam elementos abundantes na área. A associação da formação geológica está representada nesses dois grupos, respectivamente, onde acontece o processo de liberação natural entre rocha e sistema hídrico. O magnésio da região (grupo 1) provém de minerais como a dolomita (ver difratograma P9 anexo 6) e muitas vezes, é encontrado na forma de óxido, hidróxido, silicatos e carbonatos. O V (grupo 2) não possui minerais comuns a outros elementos, mas aparece presente em minérios de Fe e argilominerais, sendo separado em um grupo específico no diagrama de cluster. Segundo Borges (2009), o V "geralmente substitui o $\mathrm{Fe}^{3+}$ nos minerais, em especial na magnetita, em lugar de formar seus próprios minerais". Sua ocorrência se dá principalmente em depósitos de sulfetos associado a $\mathrm{Zn}$ e $\mathrm{Cu}$, como ocorre na mineralogia regional.

O grupo 3 é composto por metais de interesse ambiental como resíduos em fertilizantes $(\mathrm{Cu}, \mathrm{Ba}$ e $\mathrm{Zn})$, micronutrientes $(\mathrm{Cu}$ e $\mathrm{Zn})$ e princípio ativo de biocidas $(\mathrm{Cu})$ (RAMALHO, 2000). Pelo dendograma, a formação do grupo 4 reúne compostos nitrogenados com elevado potencial de eutrofização, nutrientes, óxidos, metais e sais. $\mathrm{O} \mathrm{Cl}^{-}$apresenta correlação forte com $\mathrm{NO}_{3}^{-}, \mathrm{SO}_{4}{ }^{2-}, \mathrm{HCO}_{3}^{-}, \mathrm{Ca}, \mathrm{Mg}, \mathrm{Na}, \mathrm{K}, \mathrm{NH}_{3}, \mathrm{~F}^{-}$, permanecendo no mesmo grupo hierárquico. $\mathrm{O}$ composto $\mathrm{P}_{2} \mathrm{O}_{5}$, elemento tipicamente sedimentar, forma fosfatos de origem biológica insolúveis quando associado ao $\mathrm{Fe}, \mathrm{Al}$ e Ca ficando pouco disponível aos recursos hídricos. Este elemento obteve moderada correlação com $\mathrm{Al}_{2} \mathrm{O}_{3}$, indicando acúmulo antrópico em sedimento de fundo. Neste grupo é determinante a influencia da mineralogia em que os elementos $\mathrm{Sr}$ tende a associar-se ao $\mathrm{Al}$ proveniente de minerais argilosos (filossilicatos e $\mathrm{Al}_{2} \mathrm{O}_{3}$ ). A afinidade dos elementos $\mathrm{Ca}, \mathrm{Na}, \mathrm{K}$ reflete a composição da ação intempérica.

A composição física e química das águas e sedimentos de fundo refletem a mobilidade e solubilidade dos elementos associados ao processo intempérico típico de regiões tropicais onde, $\mathrm{Na}, \mathrm{Ca}$ e $\mathrm{Mg}$ foram liberados com mais facilidade ao corpo d'água e Al, Fe tenderam a permanecer no sedimento devido sua menor mobilidade. A área é enriquecida de $\mathrm{Al}_{2} \mathrm{O}_{3}, \mathrm{SiO}_{2}, \mathrm{Fe}_{2} \mathrm{O}_{3}$ em sedimentos de fundo originados de minerais como a gibbsite, caulinita, goethita e quartzo presente em todas as amostragens. Em menor escala, o $\mathrm{TiO}_{2}$ na forma de Atanás e Óxidos $\mathrm{CaO}, \mathrm{Na}_{2} \mathrm{O}, \mathrm{K}_{2} \mathrm{O}, \mathrm{MgO}$ originados de plagioclásios (fonte de $\mathrm{Na}$ e $\mathrm{Ca}$ ), biotita (intemperiza facilmente) e feldspato potássico (fonte de $\mathrm{Mg}$ e $\mathrm{K}$ ) (minerais mais resistentes ao intemperismo). A presença dos elementos $\mathrm{Na}, \mathrm{Ca}, \mathrm{Ka}$ e $\mathrm{Mg}$ na água em valores elevados indicou fontes externas ao meio físico e geológico ao sistema aquático. 


\section{CAPÍTULO 6}

CONSIDERAÇÕES FINAIS

As diversas técnicas estatisticas e análises empregadas no decorrer da pesquisa possibilitaram a interpretação dos resultados de água e sedimentos de fundo, ampliando os conhecimentos a respeito dos processos hidrogeoquímicos do Rio das Antas em Anápolis - GO. A análise de cluster (agrupamento hierárquico) permitiu avaliar a correlação entre os parâmetros, determinando agrupamentos entre eles. Esta técnica juntamente com a correlação de Spearman, auxiliou na distinção dos parâmetros de origem geológica e humanas que mais influenciaram na composição das águas. Assim, foi possível classificar as águas de acordo com os níveis de alteração (alta mineralização, relação de nitrogenados e nutrientes com metais, elementos mais abundantes de constituição geológica) além de determinar a intensidade dos impactos da cidade na qualidade dos sistemas aquáticos.

A difração de raios-X e o índice de geoacumulação indicaram os diferentes depósitos minerais na acumulação de metais nos sedimentos. Para a região do Rio das Antas, a maioria dos metais determinados possui participação direta da aceleração do intemperismo. Valores mais elevados de concentrações em parâmetros no período chuvoso são atribuídos ao escoamento superficial, tanto urbano quanto rural. O estudo em duas estações permitiu verificar em amostras de período seco, menos abundancia de parâmetros que amostras da estação chuvosa, comportamento compatível com a liviação terrestre pela água pluvial que coloca em solução parte dos metais e outras substâncias aplicadas nos diferentes usos do solo.

A análise dos sedimentos de fundo e mineralogia ajudaram a explicar processos hidrogeoquícos de adsorção e retirada de certos metais das águas como o $\mathrm{Al}$, Fe e $\mathrm{P}_{2} \mathrm{O}_{5}$. Os resultados da pesquisa mostraram que as águas estudadas, estão altamente alteradas pela urbanização, agricultura efluentes de esgoto doméstico, industriais e atividades relacionadas ao tratamento de água e esgoto pelas ETA e ETE. As altas concentrações de vários elementos químicos foram obtidas nas regiões de intensa urbanização e atividades agrícolas, onde a vegetação natural foi substituída ou até extinta aumentando o runoff e acúmulo de particulados, sólidos dissolvidos e matéria orgânica.

Elevadas concentrações de $\mathrm{SO}_{4}{ }^{2-}, \mathrm{NO}_{3}{ }^{-}, \mathrm{Cl}^{-}, \mathrm{P}_{2} \mathrm{O}_{5}, \mathrm{Cu}, \mathrm{Ba}$ e $\mathrm{Zn}$ comprovaram as ocorrências das alterações antropogênicas no sistema hídrico. Relações entre $\mathrm{NO}_{3}{ }^{-}$e $\mathrm{NH}_{3}$, 
revelaram contaminação antiga em sedimento de fundo e água através desses rejeitos. Quantidades superiores de bactérias do grupo coliformes, utilizadas como indicadores de contaminação patogênica, apontaram para resultados não muito satisfatórios do trabalho realizado pela estação de tratamento de esgoto municipal, as quais Coliformes Totais e Escherichia Coli excedem quantitativamente os limites estabelecidos para qualidade de águas superficiais.

Os sólidos dissolvidos totais nas águas estudadas e presente nos sedimentos de fundo são compatíveis com a geologia e pedologia da área onde o $\mathrm{Al}$ e o $\mathrm{Fe}$ podem, no entanto exercer influencia sobre a agregação dos solos e determinar a cimentação irreversível (concrecionamento). O Latossolo Férrico, da mesma forma, mostra baixos teores de fases solúveis e pouco contribui para a mineralização das águas superficiais. Através das análises e da estatística multivariada foi possível construir um modelo geoquímico para quantificação dos principais elementos e óxidos da região estudada. Esse modelo pode ajudar na interpretação de resultados futuros aplicáveis a pesquisas relacionadas ao meio ambiente e recursos hídricos de Anápolis e regiões geologicamente semelhantes. 
1. ALBERS, A. P. F.; MELCHIADES, F. G.; MACHADO, R.; Baldo J. B.; BOSCHI, A. O. Um método simples de caracterização de argilominerais por difração de raios $\mathrm{X}$. Revista Cerâmica 48 (305) Jan/Fev/Mar 2002.

2. AlloWAY, B.J. Heavy metals in soils. London: Blackie Academic \& Professional, 1995. 368p.

3. AIKAWA, J. K. 1991. Magnesium. In: MERIAN, E. Metals and theirs compounds in the environment. Cambridge: VCH. 1438p.

4. ANDREAZZINI, M. J.; FIGUEIREDO, B. R.; LICHT, O. A. B. Comportamento Geoquímico do Flúor em Águas e Sedimentos Fluviais da Região de Cerro Azul, Estado do Paraná, Brasil. Revista Brasileira de Geociências, Curitiba, p. 336 - 346. 2006.

5. ANDREOLI, C. V. \& CARNEIRO, C. (2005). Gestão integrada de mananciais de abastecimento eutrofizados. Sanepar, FINEP - Curitiba - PR

6. APHA. American Public Health Association. Standard methods for the examination of water and wastewater, 21 th ed. Washington: APHA; 2005. 135p.

7. ARAÚJO, D. F. Isótopos de Cu e Zn: Metodologia e Aplicação como Traçadores de Fontes e Processos Biogeoquímicos na Bacia do Lago Paranoá-DF.Geociencias Aplicadas (Dissertação de Mestrado) UnB, 2012.

8. AZEVEDO, J. H, CAMPOS, J. E, BOAVENTURA, G. R. Influência dos Fatores Geológicos e Hidrogeológicos na Estabilidade Química das Águas Freáticas no Sul do Estado do Tocantins. São Paulo, UNESP, Geociências, v. 33, n. 1, p.73-88 , 2014.

9. BAHIA FILHO, A. F. C., BRAGA, J. M., RESENDE, M., RIBEIRO, A. C. Relação entre adsorção de Fósforo e Componentes Mineralógicos da Fração Argila de Latossolos do Planalto Central. R. bras. Cio Solo 7:221-226, 1983.

10. BALLS, P. W.; BROCKIE, N.; DOBSON, J.; JONHSTON, W. Dissolved Oxygen and Nitrification in the Upper Forth Estuary During Summer (1982-92): Patterns and Trends. Estuarine, Coastal and Shelf Science. v.42, p. 117-134, 1996.

11. BARROS, C.B.(2002). Validação dos métodos analíticos. O Biológico. São Paulo, v.64, n.2, p.175-177.

12. BIGHAM, J. M. Iron mineralogy of red-yellow hued ultisols and oxisols as determined by Mõssbauer speetroscopy X-ray difractometry and supplemental 
laboratory techniques. Tese de Mestrado. Raleigh, North Carolina State Uníversity, 1977. 1965f. Mimeo.

13. BITTON, G. (1994). Wastewater microbiology. John Wiley \& Sons, inc. Publication.

14. BOAVENTURA, G.R. 1991. Performance do Espectrômetro de Emissão com Plasma (ICP), SPECTROFLAME FVM03, para Determinação de 20 Elementos Químicos nas Amostras de Referência Geoquímica DNC-1, W-2, UNB-B1 e UNB-G1. In: Anais Congr. .Bras. Geoq. 3 ed, São Paulo: SBGq. 423-426p.

15. BONNET, B. R. P.; FERREIRA, L. G.; LOBO, F. C. Relações entre Qualidade da Água e uso do Solo em Goiás: uma análise à escala da bacia hidrográfica. Revista Árvore [online] Viçosa-MG. 2008, vol.32, n.2, p. 311-322. ISSN 0100-6762. http://dx.doi.org/10.1590/S0100-67622008000200014.

16. BRANCO, C. C. Monitoramento Rio Ribeirão das Lajes - Rio Guandu. Relatório Técnico. RJ, 2011.

17. BRANCO, S. M. (1986). Hidrobiologia aplicada à engenharia sanitária. CETESB, $3^{\circ}$ ed., São Paulo - SP.

18. BRASIL, Decreto n. ${ }^{\circ}$ 5.704, de 27 de dezembro de 2002 - Cria a Área de Proteção Ambiental (APA) João Leite e dá outras providências. Disponível em: < http://www.gabinetecivil.go.gov.br/pagina_decretos.php?id=1450>. Acesso em 256/07/2013.

19. BRASIL. Ministério da Saúde. Secretaria de Vigilância em Saúde. Vigilância e controle da qualidade da água para consumo humano/ Ministério da Saúde, Secretaria de Vigilância em Saúde. - Brasília: Ministério da Saúde, 2006. 212 p. - (Série B. Textos Básicos de Saúde) ISBN 85-334-1240-1

20. BORGES, L. O. S. Qualidade da Água e Sedimento na Bacia do Piancó em Anápolis Goiás. (Dissertação de Mestrado) UFG, Goiânia - Goiás, 2009.

21. BORTOLUZZI, E. C. RHEINHEIMER, D. S. GONÇALVES, C. S. PELLEGRINI, J.B.R. ZANELLA, R. \& COPETTI, A. C.C. Contaminação de águas superficiais por agrotóxicos em função do uso do solo numa microbacia hidrográfica de Agudo, RS- R. Br. de Eng. Agrícola e Ambiental v.10, n.4, p.881-887, 2006 Campina Grande, PB.

22. CALLEGARI-JACQUES, Sidia M. Bioestatística: princípios e aplicações. Porto Alegre: Artemed, 2003. 255p.

23. CÃLIN, D. I. \& ROŞU, C. Drinking water quality assessment of rural wells from Aiud Area. Advances in Environmental Sciences - International Journal of the Bioflux Society, Romania, 2011. 
24. CALVIN, A. B. Relationship between Land Use and Surface Water Quality in a Rapidly Developing Watershed in Southeast Louisiana, University of New Orleans-Doctor of Philosophy in Engineering and Applied Science, 2008.

25. CAMPOS, M. L. et al . Determinação de cádmio, cobre, cromo, níquel, chumbo e zinco em fosfatos de rocha. Pesq. agropec. bras., Brasília , v. 40, n. 4, Apr. 2005 . Available from <http://www.scielo.br/scielo.php?script=sci_arttext\&pid=S0100204X2005000400007\&lng=en\&nrm=iso>. access on 21 Nov. 2014.

26. CARVALHO, R. M. W. N. Determinação de íons metálicos em moluscos bivalves do manguezal da região petrolífera de São Francisco do Conde, Recôncavo Baiano. Tese (Doutorado em Química Analítica) - Instituto de Química, Universidade Estadual de Campinas, Campinas, 2006.

27. CARvalho, M. M. C. Análise Ambiental do Aterro Sanitário do Município de Anápolis Estado de Goiás. (Dissertação de Mestrado) UniEVANGÉLICA, Anápolis Goias, 2011.

28. CASTRO, J. D. B. Anápolis: desenvolvimento industrial e meio ambiente. Anápolis: AEE, 2004.

29. CASTRO, J. B. Anápolis, Progresso e Desenvolvimento, um Estudo Econômico sobre a Cidade Centenária. Revista de Economia da UEG, Anápolis (GO), Vol. 05, nº 01, JAN-JUN/2009.

30. CEBALLOS, B.S.O.; LIMA, E.O.; KONIG, A.; MARTINS, M.T. Spatial and temporal distribution of fecal coliforms, coliphages, moulds and yeasts in freshwater at the semiarid tropic northeast region in Brazil (Estado da Paraíba). Revista de Microbiologia, São Paulo, v.26, p.90-1000, 1995.

31. CEOTTO, C. S.; "Comparação de técnicas analíticas para determinação de elementos traço em soluções de amostras ambientais". (Monografia), Vitória-ES, 2009.

32. CHEN, K., JIAO, J.J., HUANG, J. \& HUANG, R. 2007. Multivariate statistical evaluation of trace elements in groundwater in a coastal area in Shenzhen, China. Environmental Pollution, Volume 147, Issue 3, p. 771-780

33. CORRÊA, J. C. 2000 Manejo do uso do solo no município de Querência, MT. Embrapa Cerrados n.26, 40p.

34. CORRÊA, F. M. Impactos Antrópicos sobre a Qualidade da Água no Rio das Antas na Área Urbana da Cidade de Anápolis-Goiás: Uma abordagem para Gestão Ambiental. Dissertação de Mestrado em Planejamento e Gestão Ambiental da Universidade Católica de Brasília, Brasília, 2005. 
35. COTTA, J. A. O.; REZENDE, M. O. O.; PIOVANI, M. R.; Avaliação do teor de metais em sedimento do Rio Betari no Parque Estadual Turistico do Alto Ribeira - Petar, São Paulo, Brasil. Revista Quim. Nova, Vol. 29, No. 1, 40-45, 2006.

36. COTTON, F.A.; WILKINSON, G.; MURILLO, C.A. \& BOCHMANN, M. (1999) Advanced Inorganic Chemistry. Sixth edition. Jonh Wiley \& Sons, Inc., USA, 1355 p.

37. COUILLARD, D.; LEFEBVRE, Y. Analysis of water quality indices. Journal of Environmental Management, v.21, p.161-179, 1985.

38. CSUROS, M. e CSUROS, C. (2000) - Environmental sampling and analysis for metals. Lewis Publishers, USA, 372 p.

39. DEER, W.A., HOWIE, R.A., ZUSSMAN, J. 1966. An Introduction to the RockForming Minerals: London, Longmans, Green and Co, 1966.

40. de OLIVEIRA, R. C. B.; MARINS, R. V. Dinâmica de Metais-Traço em Solo e Ambiente Sedimentar Estuarino como um Fator Determinante no Aporte desses Contaminantes para o Ambiente Aquático: Revisão. Revista Virtual de Química, ISSN 1984-6835, 2011, vol.3 n 2, 88-102. Data de publicação na Web: 30 de junho de 2011 http://www.uff.br/rvq.

41. DIAS, J. C.; LIMA, W. N. Comparação de Métodos para a Determinação de Matéria Orgânica em Amostras Ambientais. Revista Científica da UFPA http://www.ufpa.br/revistaic Vol 4, abril 2004.

42. DOnAdiO, N. M. M.; GAlbiatTi, J.A; PAUla, R. C. Qualidade da Água de Nascentes com Diferentes Usos do Solo na Bacia Hidrográfica do Córrego Rico, Revista Eng. Agríc., Jaboticabal, v.25, n.1, p.115-125, jan./abr. 2005 - São Paulo, Brasil, 2005.

43. ESTEVES, F. A. Fundamentos de limnologia. Rio de janeiro: Inter- ciência/FINEP, 1998. 575p.

44. EMSLEY J 1998: The Elements. $3^{\text {a }}$ ed edition. Clarendon Press, Oxford, New York, USA

45. EMBRAPA (2006)- EMPRESA BRASILEIRA DE PESQUISA AGROPECUÁRIA -. Sistema brasileiro de classificação de solos. Centro Nacional de Pesquisa de Solos, Brasília, DF.

46. EMBRAPA (2009) - Empresa Brasileira de Pesquisa Agropecuária - Manual de Análises químicas de solos, plantas e fertilizantes. $2^{\circ}$ edição. Editor técnico: Fábio Cesar da Silva.

47. FERREIRA, F. MATOS, J. S. Qualidade de Águas pluviais na zona baixa de Alcântara, em Lisboa. Revista Recursos Hídricos, Vol. 33, No 2, 59-72, novembro de 2012. (C) APRH, ISSN 0870-1741 | DOI 10.5894/rh33n 2-5 
48. FERREIRA, P. E. Caracterização socioambiental da Microbacia do Rio das Antas no município de Anápolis (GO): Subsídios para gestão e conservação. (Dissertação de Mestrado), UNIEVANGÈLICA Centro Universitário de Anápolis - GO, 2009.

49. FIORUCCI, A. R. e BENEDETTI-FILHO, E. A importância do oxigênio dissolvido em ecossistemas aquáticos. Química Nova na Escola, n. 22, p. 10-16, 2005.

50. FONSECA, JANAÍNA. C. L. MARCHI, M. R. FONSECA, JASSYARA. C. L. Substâncias químicas perigosas à saúde e ao ambiente / Organização Mundial da Saúde, Programa Internacional de Segurança Química. São Paulo: Cultura Acadêmica, 2008. 106 p.

51. FORD, H. A.; TUCKER, D. P. H. Clogging of drip systems from metabolic products of iron and sulfur bacteria. International Drip Irrigation. Congress, Proceedings... San Diego. 1986 p.212-214.

52. FORMOSO, M. L. L. Some topics on geochemistry weathering: a review. Anais da Academia Brasileira de Ciências, v.78, n.4, p.809-820, 2006.

53. FÖStner, U. G.; WITTMAnN, G. T. W.; Metal Pollution in the Aquatic Environmental, Springer-Verlag: Berlin, 1980.

54. FÖRSTNER, U. 1983. Assessment of metal pollution in rivers and estuaries. In: THORNTON, I. (ed.) Applied Environmental Geochemistry. Londres: Academic Press. 395-423pp.

55. FRANCO, R. A. M. \& HERNANDEZ, F. B. T. Qualidade da água para irrigação na microbacia do Coqueiro, Estado de São Paulo. R. Bras. Eng. Agríc. Ambiental, v.13, n.6, p.772-780, 2009.

56. FREITAS, R. A. Anápolis: Passado e Presente. Anápolis: Voga, 1995.

57. GARRELS R. M, CHRIST C. L. Solutions, minerals, and equilibria. New York: Harper \& Row, 1965. $450 \mathrm{p}$.

58. GIMENO-GARCIA, E. H. Metals incidence in the application of inorganic fertilizers and pesticides to Rice farming soil. Environmental Pollution. 92:19-25 (1996).

59. GLEESON, C. \& GRAY, N. - The Coliform Index and Waterborne Disease: problems of microbial drinking water assessment. E \&FN Spon, 1st ed., London, 1997.

60.GRAY, L.D. Escherichia, Salmonella, Shigelthla and Yersinia. In: MURRAY, P.R. (Ed.). Manual of clinical microbiology. $6^{\text {ed }}$. Washington, D.C.: American Society for Microbiology, 1995. 450-456 p.

61. GREENBERG A.E., CLESCERI L.S., EATON A.D. (ED). 1992. Standard methods for the examination of water and wastewater. $18^{\text {ed }}$. Ed. American Public Health Association. 
62. GUEDES, J. A. (a) Geoquímica e Meio Ambiente. Revista GEO Temas, Pau dos Ferros, Rio Grande do Norte, Brasil, v 2, n. 1, p. 145-151, jan/jun., 2012.

63. GUEDES, J. A. (b) Teores geoquímicos em sedimentos de fundo do rio Jundiaí, Macaíba/RN Brazilian Geographical Journal: Geosciences and Humanities research medium, Uberlândia, v. 3, n. 1, p. 70-79, jan./jun. 2012.

64. GUILFORD, J. P. Fundamental statistics in psychology and education. $4 .{ }^{\text {ed }}$. New York: McGraw-hill Book, 1950. 605p.

65. HAASE, J.; KRIEGER, J. A. \& POSSOLI, S. Estudo da viabilidade do uso da técnica fatorial como um instrumento na interpretação de qualidade das águas da bacia hidrográfica do Guaíba, RS, Brasil. Ciência e Cultura. 41:576-582, Brasil, 1989.

66. HERMES, L. C.; SILVA, A. S. Avaliação da qualidade das águas: manual prático. Brasília: Embrapa Informação Tecnológica, 2004. 55p.

67. HERNANDEZ, F. B. T.; PETINARI, R. A. Qualidade da água para irrigação localizada. In: Congresso Brasileiro de Engenharia Agrícola, 27, 1998, Poços de Caldas, Anais. Poços de Caldas: SBEA, 1998, v.II, p.58-60.

68. HESPANHOL, K. M. H. Monitoramento e Diagnóstico da Qualidade da água do Ribeirão Morangueiro (Dissertação de Mestrado), Maringá, 2009.

69. HOODA, P. Trace elements in soils . Wiley Blackwell : Oxford, 2010, 618p.

70. HOLANDA, C. E. F. BUENO, G. T. Comportamento de Elementos Químicos em Ambiente Supergênico e Pedogênese - Parque Municipal das Mangabeiras, Quadrilátero Ferrífero, MG. Revista de Geografia. Recife: UFPE - DCG/NAPA, v. especial VIII SINAGEO, n. 3, Set. 2010.

71. HORTELLANI, M. A. SARKIS, J. E. S. MENEZES, L. C. B. BAZANTEYAMAGUISHI, R. PEREIRA, A. S. A. GARCIA, P. F. G. MARUYAMA, L. S. CASTRO. P. M. G. Assessment of metal concentration in the Billings Reservoir sediments, São Paulo State, Southeastern Brazil. J. Braz. Chem. Soc. [online]. 2013, vol.24, n.1, pp. 58-67.

72. IBGE, Instituto Brasileiro de Pesquisa e Estatística. Contagem da População População recenseada e estimada segundo os municípios - Goiás, 2010.

73. IBGE - INSTITUTO BRASILEIRO DE GEOGRAFIA E ESTATÍSTICA. Carta Topográfica 1/250.000 Folha Goiânia SE.22.X.B. Brasília: IBGE,1980.

74. JAWETZ, E.; MELNICK, J.L.; ADELBERG, E.A. Microbiologia Médica. 24a ed., São Paulo: MC Graw Hill, 2009. 249-262 p. 
75. JENNE, E. A. Controls on $\mathrm{Mn}, \mathrm{Fe}, \mathrm{Co}, \mathrm{Ni}, \mathrm{Cu}$ and $\mathrm{Zn}$ concentrations in soils and water: the significant role of hydrous Mn and Fe oxides. Amer. Chem. Soc., v. 73, p. 337387, 1968. (Advances in Chemistry Series).

76. JESUS, H. C.; COSTA, E. A.; MENDONÇA, A. S. F.; ZANDONADE, E. Distribuição de Metais Pesados em Sedimentos do Sistema Estuarino da Ilha de Vitória - ES. Revista Quim. Nova, Vol. 27, No. 3, 378-386, 2004.

77. JESUS, A. S. de. Impactos Ambientais na Alta Bacia Urbana do Rio das Antas em Anápolis (GO). (Dissertação Mestrado) - IESA. Universidade Federal de Goiás, Goiânia, 2007.

78. JESUS, A. S. (2013). Investigação Multidisciplinar de Processos Erosivos Lineares: Estudo de Caso da Cidade de Anápolis - GO. Tese de Doutorado, Publicação G.T.D 087/2013, Departamento de Engenharia Civil, Universidade de Brasília, Brasília, DF, 340 p.

79. JÚNIOR, A. P. P.; SILVA, D. S.; COSTA, W. G.; FERREIRA, T. P. Avaliação FisicoQuímica do Córrego das Antas. Revista Processos Químicos - Jan / Jun de 2010.

80. KABATA-PENDIAS, A.; PENDIAS, H. Trace elements in soils and plants. $3^{\mathrm{a}}$ ed . Boca Raton: CRC Press, 2001. 413p.

81. KEMERICH, P. D. C. MARTINS, S. R. KOBIYAMA, M. SANTI, A. L. FLORES, C. E. B. BORBA, W. F. FERNANDES, G. A. CHERUBIN, M. R. Qualidade da água oriunda do escoamento superficial simulado em bacia hidrográfica. Revista Ciência e Natura, Santa Maria, ISSN: 2179-460X v. 35 n. 2 dez. 2013, p. 136-151.

82. LACERDA, H.; TEIXEIRA, L. L. F. M.; OLIVEIRA, S. N. JESUS, A. S. SANTOS, L. R. Formas de Relevo, Uso da Terra e Riscos Geológicos na Área Central de Anápolis. Plurais, v.1 n.2, jan/jun. 2005. ISSN 1807-9083.

83. LANDIM, P. M. B. Análise estatística de dados geológicos multivariados. São Paulo. Oficina de Textos. 2011. 208 p.

84. LIEU, P.T.; HEISKALA, M.; PETERSON, P.A.; YANG, Y. The roles of iron in health and disease. Molecular Aspects of Medicine, v. 22, p. 1-87, 2001.

85. LICHT, O. A. B. Prospecção geoquímica: princípios, técnicas e métodos. Rio de Janeiro: CPRM, 1998.

86. LICHT, O. A. B.; A Geoquímica Multielementar na Gestão Ambiental - Identificação e Caracterização de Províncias Geoquímicas Naturais, Alterações Antrópicas da Paisagem, Áreas Favoráveis à Prospecção Mineral e Regiões de Risco para a Saúde no Estado do Paraná, Brasil - Geologia Ambiental (Tese de Doutorado) Curitiba, 2001.

87. LIMA, J. B. M. (2004) Estudo de redes de monitoramento de qualidade das águas superficiais - O caso da bacia do Rio Descoberto. Dissertação de Mestrado, Depto de 
Engenharia Civil e Ambiental, Universidade de Brasília, Brasília, 112p., PTARH.DM$69 / 2004$.

88. LUIZ, G. C. Influência da Relação Solo-Atmosfera no Comportamento Hidromecânico de Solos Tropicais não Saturados: Estudo de Caso - Município de Goiânia-GO. Tese de Doutorado, UnB, 2012.

89. MACEDO, J. A. B. Introdução à Química Ambiental. 2a edição. Belo Horizonte: CRQMG, 2006.

90. MACEDO J. A. B. Águas \& águas. 3 a ed. Belo Horizonte:CRQ-MG, 2007, 1027p.

91. MACEDO, M. A; FREIRE, R. G.; ARGENTA, C. R.; FILHO, O. J. N. E SILVA, P. C. Modelagem de um Sistema de Informação Geográfica para Avaliação de Potencial Poluidor Hídrico das Indústrias Instaladas na Cidade de Anápolis-Go. Anápolis, 2005.

92. MAIA, Y. L. M. Análise Multielementar em Água e Sedimentos de Corrente da Bacia Hidrográfica do Rio de Meia Ponte na Região Metropolitana de Goiânia e sua Relação com a Saúde. Universidade Católica de Goiás - (Dissertação de Mestrado) em Ciências Ambientais e Saúde, Goiânia - GO, 2004.

93. MALM, O., PFEIFFER, W.C., BASTOS, W.R. [et al.]. Utilização do acessório de geração de vapor frio para análise de mercúrio em investigações ambientais por espectrofotometria de absorção atômica. Ciência e Cultura, Rio de Janeiro, 41 (1), p. 8892, jan. 1989.

94. MARTINELLI, L.A. DEVOL, A. H.; FORSBERG, B.R.; VICTORIA, R.L.; RICHEY, J.E. 1989. Descarga de sólidos dissolvidos totais do rio Amazonas e seus principais tributários. Geochimica Brasiliensis, Rio de Janeiro, v.3, p. 141-148.

95. MARTINS, C. A. S. NOGUEIRA, N. O. RIBEIRO, P. H. RIGO, M. M. CANDIDO, A. O. A dinâmica de metais-traço no solo R. Bras. Agrociência, Pelotas, v.17, n.3-4, p.383391, jul-set, 2011.

96. METCALF \& EDDY, Wastewater Engineering: treatment, disposal, reuse. MCGrawHill series in water resources and environmental engineering, $2^{\text {nd }}$ ed., 1979.

97. MENDONÇA, F.; MARQUES, G. S. Degradação Ambiental e Qualidade da Água em Bacia Hidrográfica de Abastecimento Público: Rio Timbú - PR. Revista Entre-Lugar, Dourados, MS, ano 2, n. 3, p. 111-136, $1^{\circ}$ semestre de 2011.

98. MESTRINHO, S. S. P. 1999. Qualidade das águas. In: Mestrinho S.S.P. Geoquímica e Contaminação de Águas Subterrâneas. ABAS/PE, DNPM, 47-64.

99. MIRLEAN, N.; TELLES, R. M.; DUARTE, G. M. O que é geoquímica de paisagem? Geosul, v.21, n.41, p. 2006. 
100. MOITA NETO, J. M. Estatística multivariada: Uma visão didática- metodológica. Filosofia da Ciência. 2004.

101. MORAIS, P. B. Tratamento biológico de efluentes líquidos - Tratamento físicoquímico de efluentes líquidos. UNICAMP, 2008.

102. MORAIS JÚNIOR, O. P, MENDES, R. T, PACHECO, L. C. P. da S, PELÁ, A. PELÁ, G. de M. Influência da Calagem e do Fósforo na Eficiência da adubação Foliar com Zinco em Arroz de Terras Altas. Revista Agrotecnologia, Anápolis, v. 4, n. 2, p. 01 - 16, 2013. Disponível em: http://www.prp.ueg.br/revista/index.php/agrotecnologia. Acesso: 22 de jul. 2014.

103. MOREIRA, R.C.A. \& BOAVENTURA, G.R. (2003). Referência Geoquímica Regional para a para a Interpretação das Concentrações de Elementos Químicos nos Sedimentos da Bacia do Lago Paranoá - DF. Química Nova , São Paulo, v. 26, n. 6, p. 812820, 2003.

104. MULHOLLAND, D. S., BOAVENTURA, G. R. e ARAÚJO, D. F. Geological and anthropogenic influences on sediment metal composition in the upper Paracatu River Basin, Brazil Revista Environ Earth Sci (2012) 67:1307-1317-DOI 10.1007/s12665-0121574-6 Springer-Verlag 2012

105. MÜLLER, G. Schwermetalle in den Sedimenten des Rheins Veranderungen seit. Umschau, v. 79, n. 24, p. 778-783.1979.

106. NASCIMENTO, S. C.; HYPOLITO, R.; RIBEIRO, A. A. Disponibilidade de Metais Pesados em Aterro de Indústria Siderúrgica. Nota Técnica. Eng. Sanit. Ambient. Vol.11 $\mathrm{N}^{\mathrm{o}} 3$ - jul/set 2006, 196-202

107. NAVARRO, G. R. B.; ZANARDO, A.; CONCEIÇÃO, F. T. O Grupo Araxá na região sul-sudoeste do Estado de Goiás. Geol. USP, Sér. cient. São Paulo, v. 13, n. 2, jun. 2013.

108. NEVES, S. C. HORN, A. H. FRAGA, L. M. S. Geoquímica Ambiental da Sub-Bacia Hidrográfica do Ribeirão das Pedras, Diamantina, MG. R. GEONOMOS 16(2): 63 - 68, 2008.

109. OGERA, R.C. Remoção de nitrogênio no esgoto sanitário pelo processo de lodo ativado por batelada. 1995, Dissertação (Mestrado em Engenharia Civil) - Faculdade de Engenharia Civil, Universidade Estadual de Campinas, Campinas, 1995.

110. OLIVEIRA, E. N. A., SANTOS, D.C., MARTINS, J. N., MARQUES, D. I.D. Qualidade da água para consumo humano ofertada na cidade de Limoeiro do Norte, Ceará. Tecnol. \& Ciên. Agropec., João Pessoa, v.6, n.2, p.1-5, jun. 2012.

111. OLIVEIRA, C. A., BARCELlO, W. F., COLARES, C. J. G. Estudo das Características Físico-Químicas da Água de Lavagem de Filtro em uma Estação de Tratamento de Água para Fins de Reaproveitamento. Periódico Eletrônico 
"Forum Ambiental da Alta Paulista”, v.9, p.113 - 130, 2013.

112. OLIVEIRA, C. A.; BARCELlo, W. F. e PEIXOTO, J. Análise da Qualidade de Água do Córrego dos Cesários, Anápolis/GO. Periódico Eletrônico "Forum Ambiental da Alta Paulista". v. 9 n. 2, 2013.

113. OWENS, P.N. Conceptual models and budgets for sediment management at the River Basin Scale. Journal of Soils \& Sediments, v, 5, n.4, p.201-212, 2005.

114. PÁduA, H.B de Água - Parte II. 2010. Artigo em Hypertexto. Disponível em: <http://www.infobibos.com/Artigos/2010_2/agua2/index.htm>. Acesso em: 22/7/2014

115. PALÁCIO, H.A.Q; ANDRADE, E. M.; LOPES, F. B; ALEXANDRE, D. M. B; ARRAES, F. D. D.; Similaridade da qualidade das águas superficiais da bacia do Curu, Ceará, Revista Ciência Rural, ISSN 0103-8478, v.39, n.9, p.2494-2500 Santa Maria, 2009.

116. PAUlA FILHO, F. J.; DE MOURA, M. C. S.; MARINS, R. V. Fracionamento Geoquímico do Fósforo em Água e Sedimentos do Rio Corrente, Bacia hidrográfica do Parnaíba/PI. Rev. Virtual Quim., 2012, 4 (6), 623-640. Data de publicação na Web: 7 de novembro de 2012. Disponível em: http://www.uff.br/rvq. Acesso: 15 de agosto de 2014.

117. PEREIRA, R. S. Identificação e Caracterização das Fontes de Poluição em Sistemas Hídricos - Revista Eletrônica de Recursos Hídricos IPH-UFRGS, V.1 n.1p. 20-36.2004. Disponível em: http://www.abrh.org.br/informacoes/rerh.pdf. Acesso: 25 abr. 2014.

118. PEREIRA, J. C. SIlVA, A. K. G. JÚNIOR, H. A. N. SILVA, E. P. LENA, J. C. Distribuição, Fracionamento e Mobilidade de Elementos Traço em Sedimentos Superficiais. R. Quim. Nova, Vol. 30, No. 5, 1249-1255, 2007.

119. PEREIRA, S. F. P, FILHO, H. A. D. DANTAS, K. G. F. Química AmbientalUniversidade Federal do Paraná, Instituto de Ciências Exatas e Naturais, Faculdade de Química. Paraná, 2011.

120. PETERSEN, W., BertinO, L., CAllieS, U. \& ZORITA E. 2001. Process identification by principal component analysis of river water-quality data. Ecological Modelling, 138: 193-213p.

121. PETRUF, L. A., SACCO, V. A., LUCIO. L. C. Oxigênio Dissolvido (OD), Potencial Hidrogeniônico (pH), Temperatura e Condutividade Elétrica como Parâmetros Físicos Químicos da Água do Ribeirão Morangueira, Maringá PR. Anais Eletrônico (ISBN 97885-8084-055-1) - VII EPCC - Encontro Internacional de Produção Científica Cesumar CESUMAR - Centro Universitário de Maringá. Editora CESUMAR Maringá - Paraná Brasil (2011).

122. PETRY , C. F. Determinação de Elementos Traço em Amostras Ambientais por ICP OES. (Dissertação de Mestrado em Química)- Universidade Federal do Rio Grande do Sul. Porto Alegre, 2005. 
123. PHILLIPS, D.H.; AMMONS, J.T.; LEE, S.Y. et al. Deep weathering of calcareous sedimentary rock and redistribution of iron and manganese in soil and saprolite. Soil Science. v.63, n.1, p.71-81, 1998.

124. POPOVICI, C., VERART R., VAN DE KERK G., Romania on its way to a sustainable society. Sustainable Society Index, Fundaţia pentru o Societate Durabilă, Cluj Napoca, p.48-50, 2008.

125. PORTAL ACTION, site mantido pela empresa Estatcamp - Consultoria Estatística e Qualidade. Disponível em < http://www.portalaction.com.br>. Acesso: 30/07/2013.

126. PRIMAVESI, O.; FREITAS, A.R. de; PRIMAVESI, A.C.; OLIVEIRA, H.T. de. Water quality of Canchim's creek watershed in São Paulo, SP, Brazil, occupied by beef and dairy cattle activities. Brazilian Archives of Biology and Technology, Curitiba, v.45, n.2, p.209-17, 2002.

127. PROCHNOW, T. R. PROCHNOW, E. A. LIBERMAN, B. Efeitos Antrópicos sobre Concentrações de Metais Alcalinos na Região da Microbacia do Arroio Araçá, Canoas Rio Grande do Sul. Revista Quim. Nova, Vol. 32, No. 7, 1782-1786, 2009.

128. PUC-RIO - Certificação Digital No 0511103/CA. Aplicações Industriais de Difração de Raios-X. Disponível em: rio.br/pergamum/tesesabertas/0511103_07_cap_04.pdf> Acesso: 30/07/2013.

129. RADAELli, V. A. (Org). Programa de levantamentos geológicos básicos do Brasil.Brasília: DNPM/CPRM, 1994. 136p. cap.1, p.11 -18: Geologia Regional.

130. RAMAlhO, J. F. G. P.; SOBRINHO, N. M. B. A.; Velloso, A. C. X.; Pesq. Agropec. Brasil. 2000, 35, 1289.

131. REBERTUS, R.A. \& BOUL, S.W. Iron distribution in a developmental sequence of soils from mica gneiss and schist. Soil Science Soc. Am. Journal, 49, 1985, p. 713-720.

132. REBOUÇAS, A.C; BRAGA, B. Capital Ecológico, Uso e Conservação. Águas Doces no Brasil,Capítulo 2 - Água e o Desenvolvimento Sustentável 2. ${ }^{\circ}$ Edição Revisada e Ampliada. Escrituras. São Paulo - 2002.

133. REIMANN C, DE CARITAT P. Chemical elements in the environment -factsheets for the geochemist and environmental scientist.Berlin, Germany7 Springer-Verlag; 1998. ISBN 3-540-63670-6.

134. RIBEIRO, J. F.; WALTER, B. M. T. Fitofisionomias do Bioma Cerrado. In: SANO, S. M.; ALMEIDA, S. P. Cerrado: Ambiente fauna e flora. Planaltina: EMBRAPA, 1998.

135. RIBEIRO, L. F. M. Análise da cadeia produtiva do setor de mineração de rochas para produção de agregados no Estado de Goiás, com vistas ao aproveitamento dos 
resíduos em aplicações geotécnicas. Departamento de Engenharia Civil e Ambiental, UnB. Brasília, 2008.

136. RYDING, S. O. \& RAST, R. W.. The control of eutrophication of lakes and reservoirs. Paris: UNESCO, 1989.

137. ROCHA, A. A.; BRANCO, S. M. O Nitrogênio e Fósforo como fatores limitantes ao desenvolvimento de algas cianofíceas na Represa Bilings. Revista DAE - vol.45, $\mathrm{n}^{\circ} 141$, jun.1985.

138. ROHDE, G. M. A geoquímica ambiental. In: Geoquímica ambiental e estudos de Impacto. 2 ed. São Paulo: Signus, 2004. Pp. 36-45.

139. ROSE, A.W.; HAWKES, H.E.; WEBB, J. S. Geochemistry in mineral exploration. 2 ed. New York : Academic Press, 1979.

140. ROSS, J. L. S. Geomorfologia: ambiente e planejamento. São Paulo: Contexto, 2000. (Coleção repensando a Geografia).

141. SAMPAIO, S.C; SILVESTRO, M.G; FRIGO, E. P.; BORGES, C. M. Relação entre Série de Sólidos e Condutividade Elétrica em Diferentes Águas Residuárias. Irriga, Botucatu, v. 12, n. 4, p. 557-562, 2007.

142. SANTOS A.C. 1997. Noções de hidroquímica. In: Feitosa F.A.C. e Manoel Filho J. Hidrogeologia, Conceitos e Aplicações. Fortaleza, CPRM/LABHID/UFPE, 81-108.

143. SANTOS, P. P. Indicadores Bacteriológicos de Poluição e sua Relação com Parâmetros Físico-Químicos em Água de Abastecimento Humano, Antes e Após o Tratamento, em Goiânia. Dissertação de Mestrado UFG, Goiânia, 2010.

144. SCAPIN, M. A.; Aplicação da Difração e Fluorescência de Raios X (WDXRF): Ensaios em Argilominerais. Instituto de Pesquisas Energéticas e Nucleares (Dissertação de Mestrado em Ciências na Área de Tecnologia Nuclear - Materiais) São Paulo, 2003.

145. SEKABIRA, K. ORIGA, H. O. BASAMBA T. A.; MUTUMBA, G.; KAKUDIDI, E. Heavy metal assessment and water quality values in urban stream and rain water International Journal of Environment Science and Technology, Vol. 7, No. 4, 2010, pp. 759770

146. SELENIUS, O., ALlOWAY, B., CENTENO, J. A., FINKELMAN, R. B., FUGE, R., LINDH, U. \& SMIDLEY, P. Essentials of Medical Geology: Impacts of the Natural Evironment on Public Health. Academic Press, New York.832p. 2005.

147. SGARBI, G. N. C; HORN, A. H. Ocorrência de caulinita no Espinhaço, MG. Bol. IGUSP, Sér. Cient., São Paulo, $2014 . \quad$ Disponível em $<$ http://ppegeo.igc.usp.br/scielo.php?script=sci_arttext\&pid=S010262831992000100003\&lng=pt\&nrm=iso > . acessos em 06 nov. 2014. 
148. SIEG. 2013. Sistema Estadual de Geoinformação. http://www.sieg.go.gov.br, Goiania, GO.

149. SIEGEL, F.R. Review of research on modern problems in geochemistry. Earth Sciences, United Nations Educational, Scientific and Cultural Organization, N.Y., vol. 16,1979 .

150. SILVA, D. F.; GALVÍNCIO, J. D.; ALMEIDA, H. R. R. C.; Variabilidade da Qualidade de Água na Bacia Hidrográfica do Rio São Francisco e Atividades Antrópicas relacionadas.Qualit@s Revista Eletrônica ISSN 16774280 Vol.9. No 3 (2010).

151. SILVA, A. E. P.; ANGELIS, C. F.; MACHADO, L.A.T.; WAICHAMAN, A. V.; Influência da precipitação na qualidade da água do Rio Purus. Revista ACTA AMAZONICA, vol. 38(4) 2008: 733 - 742.

152. SINGH, K. P.; MALIK, A. \& SINHA, S. 2005. Water quality assessment and apportionment of pollution sources of Gomti river (India) using multivariate statistical techniques - a case study. Analytica Chimica Acta. 538:355-374p.

153. SIQUEIRA, E. M. de A.; ALMEIDA, S. G.; ARRUDA, S. Papel adverso do ferro no organismo. Comunicação em ciências da Saúde, v. 2, n. 3, jan. 2003.

154. SPERLING, M. Introdução à qualidade de águas e ao tratamento de esgotos. 2.ed.Belo Horizonte: DESA/UFMG, 1996. 243p.

155. SPOSITO, G. Dhechemistry of soils. 2ed. USA: Oxford University Press. 2008.

156. StUMM, W.; MORGAN, J. J. 1996. Aquatic Chemistry. $3^{\text {th }}$ ed. WileyInterscience. New York, USA. 1022p.

157. STURMER, F.C.R.; MORO, E.M.P.. SERAFIM, T. Análise e controle microbiológico da água distribuída em Cruz Alta- RS, Brasil In: CONGRESSO BRASILEIRO DE MICROBIOLOGIA, 21., 2001. Foz do Iguaçu. Anais...Foz do Iguaçu: SBM, 2001, p.23.

158. TABOADA, T., CORTIZAS, A. M., GARCIA, C., GARCÍA-RODEJA E. (2006). Particle-size fractionation of titanium and zirconium during weathering and pedogenesis of granitic rocks in NW Spain. Geoderma 131, 218-236.

159. TERRA, V. R, PRATTE-SANTOS, R. ALIPRANDI, R. B, BARCELOS, F. F, MARTINS, J. L. D, AZEVEDO JR, R. R., BARBIÉRI, R. S. (2010). Estudo limnológico visando avaliação da qualidade das águas do rio Jucu Braço Norte, ES. ESFA [on line] http://www.naturezaonline.com.br. 2014, ISSN 1806-7409. Acesso 29 nov.

160. TOLEDO, L.G.; NICOLELLA, G. Índice de qualidade de água em microbacia sob uso agrícola e urbano. Scientia Agricola, v.59, n.1, p.181-186, 2002.

161. TUCCI, C. E. M.; Água no meio Urbano. Capítulo 14 do Livro Água Doce, RS, 1997. 
162. TUCCI, C. E. M. (Organizador). Hidrologia: Ciência e Aplicação, $3^{a}$ edição, Porto Alegre, Editora da UFRGS/ABRH, 2004.

163. TUDOR A., Assessment of infantile acute methemoglobine cases generated from well water consume. Sintetic Report, Institute of Public Health Bucharest. In Romanian, 2007.

164. TUNDISI, J. G.; TUNDISI, T. M., 2008. Limnologia. Oficina de Textos. São Paulo, SP.631p.

165. WEBB, J. S. Environmental problems and the exploration geochemist. In : ELLIOT, I.L.; FLETCHER, W.K. (ed.) Geochemical Exploration 1974. Amsterdam : Elsevier, 1975. p 5-17. (Developments in Economic Geology, 1).

166. WEDEPOHL K. H. (Ed). 1978. Handbook of Geochemistry. Springer Verlag, Berlin, Heidelberg, 1:248.

167. WETZEL, R. G., 2001. Limnology. 3th ed. Elsevier. Academic Press. San Diego, Califórnia, USA. 1006p.

168. WHO - World Health Organization Environmental Health Criteria; Manganese; Geneva; 1981.

169. WHO - World Health Organization, Guidelines for drinking-water quality. $2^{\text {nd }}$ ed. 1997. Disponível em: <http://www.who.int/water_sanitation_health/dwq/guidelines2/en>. Acesso em 21 de janeiro 2015.

170. WHO. World Health Organization. Guidelines for drinking water quality. In: Recommendation $3^{\text {rd }}$ ed. Geneve. 2004. Chapter 7. 1:121-144. Available at <http://www.who.org>

171. VICINI, L. (2005) Análise Multivariada da Teoria à Prática. Monografia de Especialização, UFSM, Santa Maria, 215 p.

172. VANZELA, L. S.; HERNANDEZ, F. B. T. \& FRANCO, R. A. M. Influência do uso e ocupação do solo nos recursos hídricos do Córrego Três Barras, Marinópolis, Revista Brasileira de Engenharia Agrícola e Ambiental, v. 14, n. 1, p. 55-64, Campina Grande, PB, UAEA/UFCG, 2010.

173. VIANA, E. P. T. GALDINO, P. O. FERREIRA, R. C. DANTAS, R. T. ARAUJO, K. D. Poluição do Riacho Agon em Catolé do Rocha - PB. Revista Verde (Mossoró - RN Brasil) v.4, n.3, p. 77 - 84 julho/setembro de 2009 -http://revista.gvaa.com.br.

174. VOUDOURIS, K., PANAGOPOULOS, A. \& KOUMANTAKIS, J. 2000. Multivariate Statistical Analysis in the Assessment of Hidrochemistry of the Nothern Korinthia Prefecture Alluvial quifer System (Peloponnese, Greece). Natural Resources Research, Vol. 9, 2: 135146p. 
ANEXOS 
Anexo 1 - Resultados dos parâmetros físico-químicos nas amostras de água do período seco. Turbidez (FTU), Temp. $\left({ }^{\circ} \mathrm{C}\right)$, demais parâmetros (mg $\left.L^{-1}\right)$ exceto $\mathrm{pH}$.

\begin{tabular}{|c|c|c|c|c|c|c|c|c|c|c|c|c|c|c|c|c|c|c|c|c|}
\hline & pH & C.E & Ca & Mg & $\mathrm{Na}$ & $\mathbf{K}$ & $\mathrm{NH}_{3}$ & $\mathbf{F}^{-}$ & $\mathrm{Cl}^{-}$ & $\mathrm{NO}_{3}{ }^{-}$ & $\mathrm{PO}_{4}{ }^{3-}$ & $\mathrm{SO}_{4}{ }^{2-}$ & $\mathrm{HCO}_{3}^{-}$ & $\mathrm{Fe}$ & $\mathbf{S i}$ & Al & Turb. & $\mathrm{CO}_{2}$ & TDS & Temp. \\
\hline P1 & 4,63 & 6,65 & 0,09 & 0,01 & 0,88 & 0,08 & $<\mathrm{LQ}$ & $<\mathrm{LQ}$ & 0,07 & 0,89 & $<\mathrm{LQ}$ & $<$ LQ & 1,99 & $<\mathrm{LQ}$ & 0,97 & $<\mathrm{LQ}$ & 1,00 & 38 & 2,70 & $22^{\circ}$ \\
\hline P2 & 6,54 & 40,30 & 4,43 & 0,72 & 2,26 & 0,84 & 0,07 & $<\mathrm{LQ}$ & 0,86 & 1,90 & $<\mathrm{LQ}$ & 0,30 & 20,47 & $<\mathrm{LQ}$ & 2,71 & $<\mathrm{LQ}$ & 1,00 & 8,1 & 18,80 & $23^{\circ}$ \\
\hline P3 & 6,53 & 40,40 & 4,11 & 0,77 & 2,82 & 0,77 & 0,07 & $<\mathrm{LQ}$ & 1,29 & 0,80 & $<\mathrm{LQ}$ & 2,82 & 17,91 & $<\mathrm{LQ}$ & 2,76 & $<\mathrm{LQ}$ & 5,00 & 7,04 & 18,80 & $23^{\circ}$ \\
\hline P4 & 7,00 & 138,50 & 14,17 & 3,62 & 7,61 & 2,94 & 0,78 & $<\mathrm{LQ}$ & 4,73 & 6,92 & $<\mathrm{LQ}$ & 4,93 & 64,21 & $<\mathrm{LQ}$ & 3,68 & $<\mathrm{LQ}$ & 17,00 & 8,8 & 66,00 & $24^{\circ}$ \\
\hline P5 & 7,08 & 99,30 & 7,19 & 1,44 & 10,21 & 1,84 & 1,93 & $<\mathrm{LQ}$ & 4,38 & 2,50 & $<\mathrm{LQ}$ & 3,55 & 46,43 & $<\mathrm{LQ}$ & 3,87 & $<\mathrm{LQ}$ & 270,00 & 4,58 & 47,10 & $26^{\circ}$ \\
\hline P6 & 6,78 & 133,00 & 9,00 & 2,82 & 12,66 & 2,43 & 1,12 & 1,16 & 8,70 & 15,36 & $<\mathrm{LQ}$ & 5,55 & 39,45 & $<\mathrm{LQ}$ & 4,16 & $<\mathrm{LQ}$ & 19,00 & 12,3 & 63,20 & $23^{\circ}$ \\
\hline P7 & 6,83 & 157,30 & 10,99 & 3,18 & 14,83 & 3,07 & 2,30 & 0,15 & 10,21 & 12,87 & $<\mathrm{LQ}$ & 5,16 & 56,29 & $<\mathrm{LQ}$ & 3,99 & $<\mathrm{LQ}$ & 9,00 & 12,7 & 75,10 & $22^{\circ}$ \\
\hline P8 & 7,15 & 164,10 & 12,28 & 3,54 & 13,33 & 2,91 & 1,85 & 0,11 & 9,16 & 13,12 & $<\mathrm{LQ}$ & 4,24 & 59,95 & $<\mathrm{LQ}$ & 4,31 & $<\mathrm{LQ}$ & 4,00 & 7,39 & 78,70 & $23^{\circ}$ \\
\hline P9 & 7,14 & 144,20 & 12,13 & 2,20 & 13,42 & 2,53 & 1,12 & $<\mathrm{LQ}$ & 7,30 & 12,15 & $<\mathrm{LQ}$ & 3,11 & 56,74 & $<\mathrm{LQ}$ & 3,94 & $<\mathrm{LQ}$ & 4,00 & 7,39 & 68,70 & $22^{\circ}$ \\
\hline P10 & 6,70 & 81,10 & 6,49 & 1,04 & 8,18 & 1,70 & 0,48 & $<\mathrm{LQ}$ & 3,90 & 12,29 & $<\mathrm{LQ}$ & 2,04 & 27,64 & $<\mathrm{LQ}$ & 2,59 & $<\mathrm{LQ}$ & 1,00 & 7,04 & 42,20 & $20^{\circ}$ \\
\hline P11 & 7,07 & 140,80 & 11,77 & 2,86 & 11,23 & 2,53 & 0,90 & 0,11 & 7,13 & 14,44 & $<\mathrm{LQ}$ & 4,08 & 51,60 & $<\mathrm{LQ}$ & 3,89 & $<\mathrm{LQ}$ & 1,00 & 6,69 & 67,10 & $23^{\circ}$ \\
\hline P12 & 6,24 & 16,12 & 1,79 & 0,38 & 1,20 & 0,20 & $<\mathrm{LQ}$ & $<\mathrm{LQ}$ & 0,79 & 0,40 & $<\mathrm{LQ}$ & 2,28 & 6,62 & $<\mathrm{LQ}$ & 3,03 & $<\mathrm{LQ}$ & 6,00 & 8,8 & 7,20 & $18^{\circ}$ \\
\hline P13 & 6,91 & 112,00 & 9,63 & 2,04 & 10,23 & 0,68 & 0,07 & $<\mathrm{LQ}$ & 5,40 & 18,39 & $<\mathrm{LQ}$ & 1,80 & 37,86 & $<\mathrm{LQ}$ & 3,08 & $<\mathrm{LQ}$ & 1,00 & 6,34 & 53,20 & $22^{\circ}$ \\
\hline P14 & 7,05 & 144,00 & 11,41 & 2,42 & 12,09 & 2,64 & 0,56 & $<\mathrm{LQ}$ & 8,84 & 11,75 & $<\mathrm{LQ}$ & 4,44 & 51,09 & $<\mathrm{LQ}$ & 4,34 & $<\mathrm{LQ}$ & 2,00 & 6,69 & 68,60 & $27^{\circ}$ \\
\hline P15 & 6,70 & 41,10 & 3,16 & 0,83 & 3,95 & 0,50 & $<\mathrm{LQ}$ & $<\mathrm{LQ}$ & 2,92 & 2,20 & $<\mathrm{LQ}$ & 3,40 & 15,01 & 0,47 & 2,96 & $<\mathrm{LQ}$ & 8,00 & 4,58 & 19,20 & $21^{\circ}$ \\
\hline P16 & 6,50 & 18,30 & 1,27 & 0,78 & 1,07 & 0,94 & 0,10 & $<\mathrm{LQ}$ & 0,76 & 1,51 & $<\mathrm{LQ}$ & 0,12 & 10,11 & 0,20 & 3,79 & $<\mathrm{LQ}$ & 4,00 & 5,98 & 8,20 & $19^{\circ}$ \\
\hline P17 & 6,78 & 102,60 & 6,29 & 1,61 & 10,75 & 1,96 & 1,38 & 0,10 & 4,79 & 2,66 & $<\mathrm{LQ}$ & 4,14 & 43,35 & 0,23 & 3,99 & $<\mathrm{LQ}$ & 6,00 & 9,5 & 48,70 & $19^{\circ}$ \\
\hline P18 & 6,80 & 48,60 & 2,90 & 1,06 & 4,03 & 1,23 & 0,48 & $<\mathrm{LQ}$ & 2,00 & 1,36 & $<\mathrm{LQ}$ & 1,72 & 22,25 & 0,25 & 3,73 & $<\mathrm{LQ}$ & 4,00 & 7,04 & 22,70 & $19^{\circ}$ \\
\hline P19 & 6,60 & 30,20 & 2,41 & 1,40 & 1,68 & 0,70 & 0,08 & $<\mathrm{LQ}$ & 0,29 & 0,21 & $<\mathrm{LQ}$ & 0,36 & 18,96 & $<\mathrm{LQ}$ & 6,88 & $<\mathrm{LQ}$ & 5,00 & 8,1 & 13,90 & $19^{\circ}$ \\
\hline P20 & 6,76 & 38,10 & 2,73 & 1,97 & 1,66 & 0,84 & 0,04 & $<\mathrm{LQ}$ & 1,04 & 1,30 & $<\mathrm{LQ}$ & 0,31 & 20,40 & $<\mathrm{LQ}$ & 5,66 & $<\mathrm{LQ}$ & 4,00 & 5,28 & 17,70 & $19^{\circ}$ \\
\hline P21 & 6,83 & 91,30 & 6,20 & 1,48 & 10,02 & 1,80 & 0,97 & 0,13 & 3,84 & 2,90 & $<\mathrm{LQ}$ & 3,14 & 40,97 & 0,20 & 3,83 & $<\mathrm{LQ}$ & 3,00 & 9,5 & 43,30 & $19^{\circ}$ \\
\hline P22 & 6,83 & 91,50 & 6,20 & 1,47 & 10,30 & 1,88 & 1,00 & 0,08 & 4,20 & 3,53 & $<\mathrm{LQ}$ & 3,00 & 39,90 & 0,21 & 3,79 & $<\mathrm{LQ}$ & 5,00 & 10,6 & 43,40 & $20^{\circ}$ \\
\hline
\end{tabular}


Anexo 2 - Resultados dos parâmetros físico-químicos nas amostras de água do período chuvoso. Turbidez (FTU), Temp. $\left({ }^{\circ} \mathrm{C}\right)$, demais parâmetros $\left(m g L^{-1}\right)$ exceto $\mathrm{pH}$.

\begin{tabular}{|c|c|c|c|c|c|c|c|c|c|c|c|c|c|c|c|c|c|c|c|c|}
\hline & pH & C.E & $\mathrm{Ca}$ & $\mathrm{Mg}$ & $\mathbf{N a}$ & $\mathbf{K}$ & $\mathrm{NH}_{3}$ & $\mathbf{F}^{-}$ & $\mathrm{Cl}^{-}$ & $\mathrm{NO}_{3}{ }^{-}$ & $\mathrm{PO}_{4}{ }^{3-}$ & $\mathrm{SO}_{4}{ }^{2-}$ & $\mathrm{HCO}_{3}{ }^{-}$ & $\mathbf{F e}$ & $\mathbf{S i}$ & Al & Turb. & $\mathrm{CO}_{2}$ & TDS & Temp. \\
\hline P1 & 4,93 & 9,73 & 0,41 & 0,06 & 0,92 & 0,15 & $<\mathrm{LQ}$ & $<\mathrm{LQ}$ & 0,39 & 0,69 & $<\mathrm{LQ}$ & $<\mathrm{LQ}$ & 3,86 & $<\mathrm{LQ}$ & 1,15 & $<\mathrm{LQ}$ & 2,00 & 11,62 & 4,10 & $20^{\circ}$ \\
\hline P2 & 7,02 & 74,40 & 10,33 & 1,20 & 2,21 & 1,06 & $<\mathrm{LQ}$ & $<\mathrm{LQ}$ & 1,15 & 1,74 & $<\mathrm{LQ}$ & 0,79 & 40,22 & $<\mathrm{LQ}$ & 2,72 & $<\mathrm{LQ}$ & 17,00 & 3,17 & 35,10 & $25^{\circ}$ \\
\hline P3 & 7,05 & 79,50 & 10,26 & 1,48 & 2,94 & 1,07 & $<\mathrm{LQ}$ & $<\mathrm{LQ}$ & 1,49 & 2,95 & $<\mathrm{LQ}$ & 1,83 & 40,59 & $<\mathrm{LQ}$ & 3,25 & $<\mathrm{LQ}$ & 24,00 & 4,93 & 37,60 & $26^{\circ}$ \\
\hline P4 & 7,12 & 106,00 & 14,62 & 1,78 & 3,46 & 1,18 & 0,48 & $<\mathrm{LQ}$ & 1,60 & 2,88 & $<\mathrm{LQ}$ & 1,37 & 57,19 & $<\mathrm{LQ}$ & 3,37 & $<\mathrm{LQ}$ & 19,00 & 3,52 & 44,50 & $27^{\circ}$ \\
\hline P5 & 7,36 & 169,50 & 19,36 & 2,65 & 10,63 & 2,13 & 0,63 & $<\mathrm{LQ}$ & 6,52 & 15,47 & $<\mathrm{LQ}$ & 3,64 & 72,10 & $<\mathrm{LQ}$ & 4,44 & $<\mathrm{LQ}$ & 95,00 & 3,17 & 80,90 & $27^{\circ}$ \\
\hline P6 & 7,10 & 209,00 & 19,34 & 2,65 & 18,17 & 3,67 & 1,55 & 0,11 & 8,05 & 5,59 & $<\mathrm{LQ}$ & 7,27 & 97,71 & $<\mathrm{LQ}$ & 4,07 & $<\mathrm{LQ}$ & 170,00 & 7,04 & 100,00 & $27^{\circ}$ \\
\hline P7 & 7,06 & 232,00 & 23,14 & 2,65 & 18,58 & 3,62 & 2,45 & 0,11 & 9,25 & 9,36 & $<\mathrm{LQ}$ & 7,80 & 105,94 & $<\mathrm{LQ}$ & 4,43 & $<\mathrm{LQ}$ & 62,00 & 6,34 & 111,10 & $29^{\circ}$ \\
\hline P8 & 7,08 & 159,00 & 17,83 & 2,72 & 9,75 & 2,52 & 1,76 & $<\mathrm{LQ}$ & 5,35 & 11,09 & 0,74 & 3,30 & 71,78 & 0,46 & 4,44 & 0,88 & 461,00 & 6,51 & 75,90 & $28^{\circ}$ \\
\hline P9 & 7,00 & 231,00 & 22,66 & 3,02 & 19,44 & 3,49 & 2,40 & 0,10 & 9,80 & 10,99 & $<\mathrm{LQ}$ & 7,57 & 102,75 & $<\mathrm{LQ}$ & 4,26 & $<\mathrm{LQ}$ & 116,00 & 7,39 & 110,50 & $29^{\circ}$ \\
\hline P10 & 7,26 & 148,20 & 25,18 & 1,37 & 1,09 & 2,29 & $<\mathrm{LQ}$ & $<\mathrm{LQ}$ & 4,66 & 14,19 & $<\mathrm{LQ}$ & 2,63 & 65,14 & $<\mathrm{LQ}$ & 3,14 & $<\mathrm{LQ}$ & 9,00 & 1,76 & 70,70 & $26^{\circ}$ \\
\hline P11 & 6,96 & 235,00 & 37,23 & 3,05 & 3,80 & 3,50 & 1,84 & 0,09 & 9,89 & 10,64 & $<\mathrm{LQ}$ & 7,75 & 105,59 & $<\mathrm{LQ}$ & 4,18 & $<\mathrm{LQ}$ & 147,00 & 4,22 & 112,70 & $25^{\circ}$ \\
\hline P12 & 6,44 & 100,40 & 10,71 & 0,88 & 8,35 & 1,22 & 1,03 & $<\mathrm{LQ}$ & 2,88 & 1,18 & $<\mathrm{LQ}$ & 5,70 & 47,97 & 0,23 & 3,60 & $<\mathrm{LQ}$ & 12,00 & 5,28 & 47,60 & $21^{\circ}$ \\
\hline P13 & 6,94 & 230,00 & 36,04 & 1,87 & 6,49 & 3,22 & 1,65 & 0,11 & 9,57 & 10,75 & $<\mathrm{LQ}$ & 8,47 & 101,93 & $<\mathrm{LQ}$ & 3,90 & $<\mathrm{LQ}$ & 121,00 & 5,63 & 110,30 & $25^{\circ}$ \\
\hline P14 & 7,17 & 192,00 & 21,64 & 2,70 & 13,48 & 1,22 & $<\mathrm{LQ}$ & $<\mathrm{LQ}$ & 6,30 & 17,80 & $<\mathrm{LQ}$ & 1,20 & 88,41 & $<\mathrm{LQ}$ & 3,16 & $<\mathrm{LQ}$ & 4,00 & 3,52 & 91,80 & $29^{\circ}$ \\
\hline P15 & 6,95 & 224,00 & 24,65 & 2,92 & 16,12 & 3,18 & 1,40 & 0,08 & 9,53 & 10,28 & $<\mathrm{LQ}$ & 7,79 & 101,38 & $<\mathrm{LQ}$ & 4,15 & 0,26 & 104,00 & 3,52 & 107,50 & $26^{\circ}$ \\
\hline P16 & 7,02 & 203,00 & 22,32 & 2,81 & 13,85 & 2,93 & 1,12 & 0,10 & 8,19 & 9,05 & $<\mathrm{LQ}$ & 6,60 & 92,69 & $<\mathrm{LQ}$ & 4,08 & $<\mathrm{LQ}$ & 82,00 & 5,28 & 97,30 & $24^{\circ}$ \\
\hline P17 & 6,52 & 26,00 & 2,17 & 0,99 & 1,22 & 0,76 & $<\mathrm{LQ}$ & $<\mathrm{LQ}$ & 0,71 & 0,65 & $<\mathrm{LQ}$ & 0,39 & 13,22 & 0,61 & 3,91 & $<\mathrm{LQ}$ & 23,00 & 2,11 & 11,90 & $24^{\circ}$ \\
\hline P18 & 7,10 & 145,80 & 18,50 & 2,10 & 0,33 & 0,04 & 1,03 & $<\mathrm{LQ}$ & 5,01 & 9,19 & $<\mathrm{LQ}$ & 3,20 & 68,90 & 0,50 & 3,80 & $<\mathrm{LQ}$ & 99,00 & 5,28 & 69,50 & $24^{\circ}$ \\
\hline P19 & 6,22 & 34,10 & 2,73 & 1,36 & 1,56 & 0,69 & $<\mathrm{LQ}$ & $<\mathrm{LQ}$ & 0,79 & 0,31 & $<\mathrm{LQ}$ & $<\mathrm{LQ}$ & 19,62 & 0,84 & 4,64 & $<\mathrm{LQ}$ & 24,00 & 3,87 & 15,80 & $24^{\circ}$ \\
\hline P20 & 6,85 & 53,00 & 4,68 & 2,58 & 1,20 & 0,85 & $<\mathrm{LQ}$ & $<\mathrm{LQ}$ & 0,99 & 1,59 & $<\mathrm{LQ}$ & 0,55 & 27,78 & 0,43 & 5,48 & $<\mathrm{LQ}$ & 24,00 & 3,52 & 24,90 & $24^{\circ}$ \\
\hline P21 & 7,19 & 132,20 & 18,61 & 1,91 & 4,51 & 1,99 & 0,62 & 0,10 & 4,45 & 8,20 & 0,72 & 3,12 & 58,49 & $<\mathrm{LQ}$ & 3,79 & $<\mathrm{LQ}$ & 103,00 & 3,52 & 62,90 & $24^{\circ}$ \\
\hline P22 & 7,43 & 155,10 & 19,50 & 2,05 & 7,80 & 2,10 & 0,48 & $<\mathrm{LQ}$ & 5,10 & 13,12 & $<\mathrm{LQ}$ & 3,68 & 68,69 & 0,40 & 4,50 & $<\mathrm{LQ}$ & 147,00 & 3,17 & 74,00 & $25^{\circ}$ \\
\hline
\end{tabular}


Anexo 3 - Resultados da Análise de Sedimento de Fundo dos Elementos-Traço (ppm)

\begin{tabular}{|c|c|c|c|c|c|c|c|c|c|}
\hline & $\mathrm{Sr}$ & $\mathbf{B a}$ & $\mathbf{V}$ & $\mathrm{Cr}$ & Mn & Co & $\mathrm{Ni}$ & $\mathrm{Cu}$ & $\mathbf{Z n}$ \\
\hline P1 & 3,40 & 21,10 & 317,10 & 75,60 & 55,80 & 3,20 & 11,00 & 47,40 & 32,90 \\
\hline $\mathbf{P 2}$ & 20,00 & 311,10 & 232,00 & 94,10 & 2047,50 & 39,90 & 43,50 & 75,90 & 102,60 \\
\hline P3 & 8,30 & 66,60 & 303,90 & 198,00 & 423,70 & 19,40 & 45,80 & 157,10 & 104,70 \\
\hline P4 & 10,40 & 72,80 & 251,60 & 107,60 & 368,50 & 14,00 & 33,30 & 68,70 & 73,00 \\
\hline P5 & 10,00 & 138,00 & 291,40 & 162,90 & 545,20 & 19,50 & 54,70 & 90,40 & 105,30 \\
\hline P6 & 30,00 & 157,40 & 315,80 & 125,60 & 747,70 & 21,80 & 36,20 & 264,30 & 204,90 \\
\hline P7 & 20,60 & 225,70 & 306,90 & 130,00 & 725,10 & 23,40 & 51,40 & 211,80 & 248,70 \\
\hline P8 & 14,30 & 184,60 & 270,40 & 159,20 & 611,60 & 22,10 & 52,90 & 133,10 & 148,60 \\
\hline P9 & 14,30 & 160,80 & 238,00 & 202,70 & 541,30 & 23,90 & 74,50 & 72,00 & 111,40 \\
\hline P10 & 15,90 & 93,10 & 352,50 & 180,00 & 445,00 & 25,30 & 69,50 & 105,20 & 113,50 \\
\hline P11 & 4,10 & 32,40 & 340,10 & 97,00 & 168,80 & 9,60 & 25,80 & 89,70 & 81,30 \\
\hline P12 & 16,10 & 180,80 & 282,00 & 158,90 & 788,90 & 26,20 & 58,80 & 91,70 & 138,30 \\
\hline P13 & 6,40 & 60,00 & 319,20 & 162,60 & 90,10 & 9,50 & 45,70 & 78,00 & 92,80 \\
\hline P14 & 3,90 & 52,60 & 298,00 & 173,40 & 215,40 & 24,80 & 31,50 & 78,90 & 65,00 \\
\hline P15 & 14,50 & 172,30 & 272,80 & 161,90 & 448,60 & 23,80 & 56,90 & 81,70 & 118,60 \\
\hline P16 & 9,30 & 129,50 & 225,90 & 140,00 & 483,90 & 19,40 & 38,90 & 64,00 & 98,60 \\
\hline P17 & 4,60 & 128,10 & 172,20 & 82,80 & 406,10 & 14,00 & 24,40 & 44,90 & 112,70 \\
\hline P18 & 10,60 & 104,90 & 236,00 & 140,70 & 299,50 & 18,50 & 48,70 & 59,90 & 80,90 \\
\hline P19 & 8,50 & 119,20 & 215,60 & 147,50 & 426,70 & 19,20 & 44,30 & 63,60 & 81,70 \\
\hline P20 & 8,70 & 126,00 & 207,10 & 132,10 & 141,20 & 12,30 & 39,70 & 34,50 & 52,50 \\
\hline P21 & 2,90 & 85,60 & 171,10 & 127,70 & 547,60 & 20,40 & 36,50 & 72,50 & 80,80 \\
\hline P22 & 10,40 & 89,30 & 181,40 & 129,80 & 428,20 & 16,50 & 36,40 & 43,90 & 77,80 \\
\hline
\end{tabular}


Anexo 4-I $I_{\text {geo }}$ Calculado para Óxidos (\%)

\begin{tabular}{|c|c|c|c|c|c|c|c|c|c|}
\hline & $\mathrm{SiO}_{2}$ & $\mathrm{Al}_{2} \mathrm{O}_{3}$ & $\mathrm{Fe}_{2} \mathrm{O}_{3}$ & $\mathrm{CaO}$ & MgO & $\mathrm{TiO}_{2}$ & $\mathrm{Na}_{2} \mathrm{O}$ & $\mathbf{K}_{2} \mathbf{O}$ & $\mathbf{P}_{2} \mathbf{O}_{5}$ \\
\hline P1 & $-0,58$ & $-0,58$ & $-0,58$ & $-0,58$ & $-0,58$ & $-0,58$ & $-0,58$ & $-0,58$ & $-0,58$ \\
\hline P2 & 0,14 & $-0,71$ & 0,66 & $-1,32$ & 4,32 & $-0,49$ & $-0,10$ & 0,42 & $-0,45$ \\
\hline P3 & 0,03 & $-0,67$ & 0,78 & $-1,10$ & 2,74 & $-0,40$ & $-0,32$ & 1,00 & $-0,48$ \\
\hline P4 & 0,22 & $-0,72$ & 0,42 & $-0,32$ & 3,74 & $-1,12$ & 0,09 & 1,00 & $-0,61$ \\
\hline P5 & 0,16 & $-0,70$ & 0,23 & $-0,74$ & 4,32 & $-1,20$ & $-0,10$ & 1,42 & $-0,48$ \\
\hline P6 & 0,27 & $-0,71$ & 0,38 & 0,26 & 5,74 & $-1,27$ & 0,55 & 1,74 & 0,36 \\
\hline P7 & 0,16 & $-0,67$ & 0,32 & $-0,32$ & 4,74 & $-1,36$ & 0,26 & 1,42 & 0,94 \\
\hline P8 & 0,20 & $-0,73$ & 0,14 & 0,00 & 5,32 & $-0,74$ & 0,42 & 2,42 & $-0,11$ \\
\hline P9 & 0,29 & $-0,85$ & 0,12 & 0,68 & 7,38 & $-0,80$ & 0,09 & 1,74 & $-0,54$ \\
\hline P10 & 0,11 & $-0,68$ & 0,37 & $-0,10$ & 5,32 & $-0,64$ & 0,09 & 1,42 & $-0,17$ \\
\hline P11 & $-0,08$ & $-0,36$ & 0,15 & $-1,10$ & 3,74 & $-0,86$ & $-0,32$ & 1,00 & $-0,29$ \\
\hline P12 & 0,48 & $-0,89$ & 0,03 & $-0,10$ & 5,74 & $-0,16$ & 0,26 & 2,42 & $-0,16$ \\
\hline P13 & 0,34 & $-0,73$ & $-0,20$ & $-1,10$ & 2,74 & $-0,27$ & $-0,10$ & 1,00 & $-0,69$ \\
\hline P14 & $-0,03$ & $-0,63$ & 0,26 & $-1,32$ & 2,74 & $-1,05$ & $-0,32$ & 0,42 & $-0,47$ \\
\hline P15 & 0,29 & $-0,73$ & 0,17 & 0,00 & 6,06 & $-1,12$ & 0,42 & 1,74 & $-1,05$ \\
\hline P16 & 0,56 & $-0,82$ & 0,14 & $-0,32$ & 5,54 & $-0,86$ & 0,09 & 1,74 & $-1,10$ \\
\hline P17 & 0,81 & $-0,97$ & $-0,51$ & $-1,10$ & 4,74 & $-0,80$ & 0,09 & 2,42 & $-0,74$ \\
\hline P18 & 0,81 & $-1,03$ & 0,09 & $-0,45$ & 5,06 & $-0,86$ & $-0,58$ & 1,42 & $-0,63$ \\
\hline P19 & 0,83 & $-1,14$ & 0,34 & $-0,21$ & 5,54 & $-0,92$ & $-0,58$ & 2,22 & $-0,96$ \\
\hline P20 & 1,04 & $-1,16$ & $-0,88$ & $-0,91$ & 5,06 & $-0,69$ & 0,09 & 2,00 & $-0,94$ \\
\hline P21 & 0,91 & $-1,13$ & $-0,20$ & $-0,58$ & 5,54 & $-0,98$ & $-0,32$ & 2,87 & $-0,67$ \\
\hline $\mathbf{P 2 2}$ & 0,90 & $-1,05$ & $-0,37$ & $-0,74$ & 5,32 & $-0,64$ & $-0,10$ & 2,74 & $-0,81$ \\
\hline
\end{tabular}


Anexo 5-I $I_{\text {geo }}$ Calculado para Elementos-Traço (ppm)

\begin{tabular}{|c|c|c|c|c|c|c|c|c|c|}
\hline & $\mathrm{Sr}$ & $\mathbf{B a}$ & $\mathbf{V}$ & $\mathrm{Cr}$ & Mn & Co & $\mathbf{N i}$ & $\mathrm{Cu}$ & $\mathrm{Zn}$ \\
\hline P1 & $-0,58$ & $-0,58$ & $-0,58$ & $-0,58$ & $-0,58$ & $-0,58$ & $-0,58$ & $-0,58$ & $-0,58$ \\
\hline P2 & 1,97 & 3,30 & $-1,04$ & $-0,27$ & 4,61 & 3,06 & 1,40 & 0,09 & 1,06 \\
\hline P3 & 0,70 & 1,07 & $-0,65$ & 0,80 & 2,34 & 2,01 & 1,47 & 1,14 & 1,09 \\
\hline P4 & 1,03 & 1,20 & $-0,92$ & $-0,08$ & 2,14 & 1,54 & 1,01 & $-0,05$ & 0,56 \\
\hline P5 & 0,97 & 2,12 & $-0,71$ & 0,52 & 2,70 & 2,02 & 1,73 & 0,35 & 1,09 \\
\hline P6 & 2,56 & 2,31 & $-0,59$ & 0,15 & 3,16 & 2,18 & 1,13 & 1,89 & 2,05 \\
\hline P7 & 2,01 & 2,83 & $-0,63$ & 0,20 & 3,11 & 2,29 & 1,64 & 1,57 & 2,33 \\
\hline P8 & 1,49 & 2,54 & $-0,81$ & 0,49 & 2,87 & 2,20 & 1,68 & 0,90 & 1,59 \\
\hline P9 & 1,49 & 2,34 & $-1,00$ & 0,84 & 2,69 & 2,32 & 2,17 & 0,02 & 1,17 \\
\hline P10 & 1,64 & 1,56 & $-0,43$ & 0,67 & 2,41 & 2,40 & 2,07 & 0,57 & 1,20 \\
\hline P11 & $-0,31$ & 0,03 & $-0,48$ & $-0,23$ & 1,01 & 1,00 & 0,64 & 0,34 & 0,72 \\
\hline P12 & 1,66 & 2,51 & $-0,75$ & 0,49 & 3,24 & 2,45 & 1,83 & 0,37 & 1,49 \\
\hline P13 & 0,33 & 0,92 & $-0,58$ & 0,52 & 0,11 & 0,98 & 1,47 & 0,13 & 0,91 \\
\hline P14 & $-0,39$ & 0,73 & $-0,67$ & 0,61 & 1,36 & 2,37 & 0,93 & 0,15 & 0,40 \\
\hline P15 & 1,51 & 2,44 & $-0,80$ & 0,51 & 2,42 & 2,31 & 1,79 & 0,20 & 1,26 \\
\hline P16 & 0,87 & 2,03 & $-1,07$ & 0,30 & 2,53 & 2,01 & 1,24 & $-0,15$ & 1,00 \\
\hline P17 & $-0,15$ & 2,02 & $-1,47$ & $-0,45$ & 2,28 & 1,54 & 0,56 & $-0,66$ & 1,19 \\
\hline P18 & 1,06 & 1,73 & $-1,01$ & 0,31 & 1,84 & 1,95 & 1,56 & $-0,25$ & 0,71 \\
\hline P19 & 0,74 & 1,91 & $-1,14$ & 0,38 & 2,35 & 2,00 & 1,42 & $-0,16$ & 0,73 \\
\hline P20 & 0,77 & 1,99 & $-1,20$ & 0,22 & 0,75 & 1,36 & 1,27 & $-1,04$ & 0,09 \\
\hline P21 & $-0,81$ & 1,44 & $-1,48$ & 0,17 & 2,71 & 2,09 & 1,15 & 0,03 & 0,71 \\
\hline P22 & 1,03 & 1,50 & $-1,39$ & 0,19 & 2,35 & 1,78 & 1,14 & $-0,70$ & 0,66 \\
\hline
\end{tabular}




\section{Anexo 6 - Difratogramas obtidos nas análises mineralógicas}

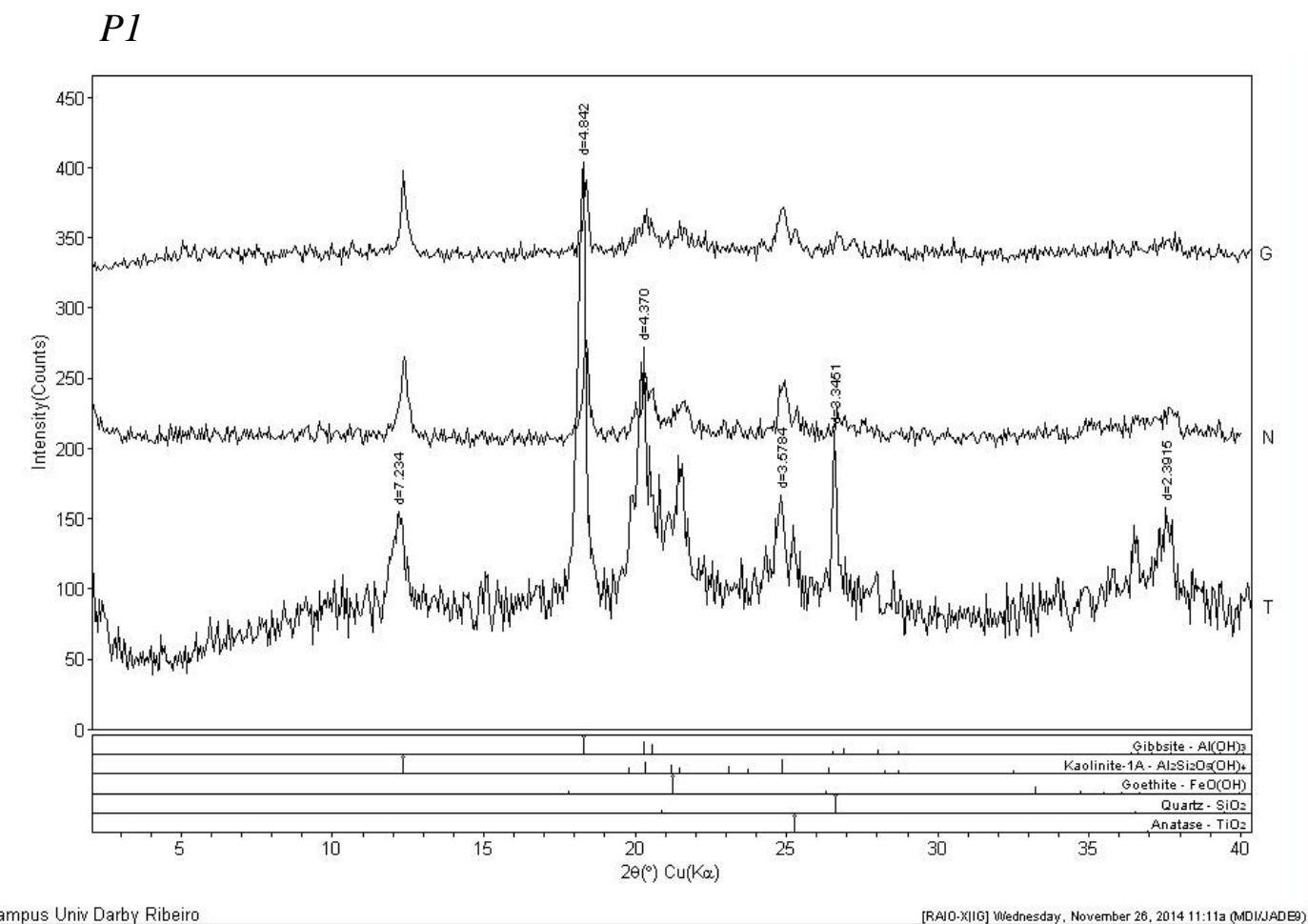

$\mathrm{P} 2$

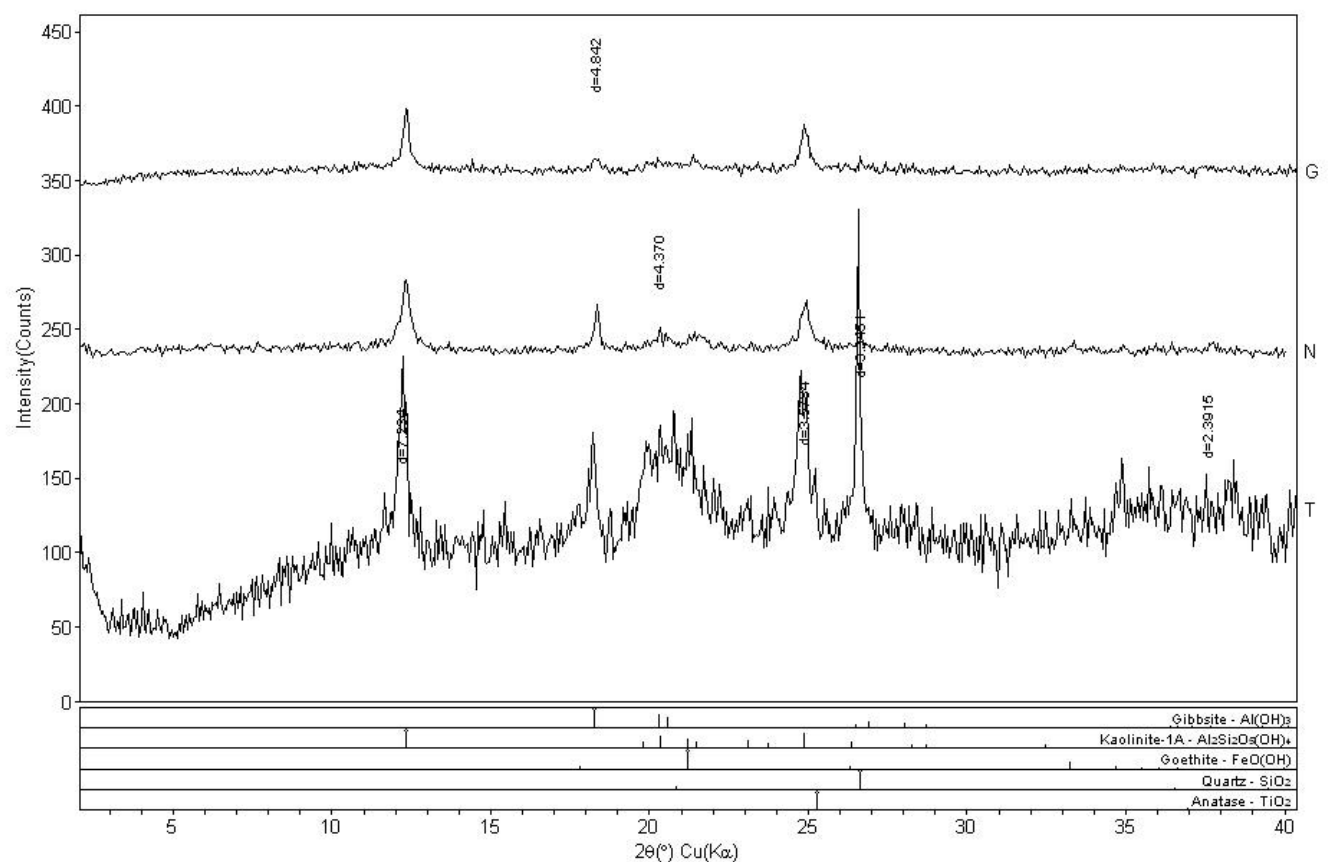



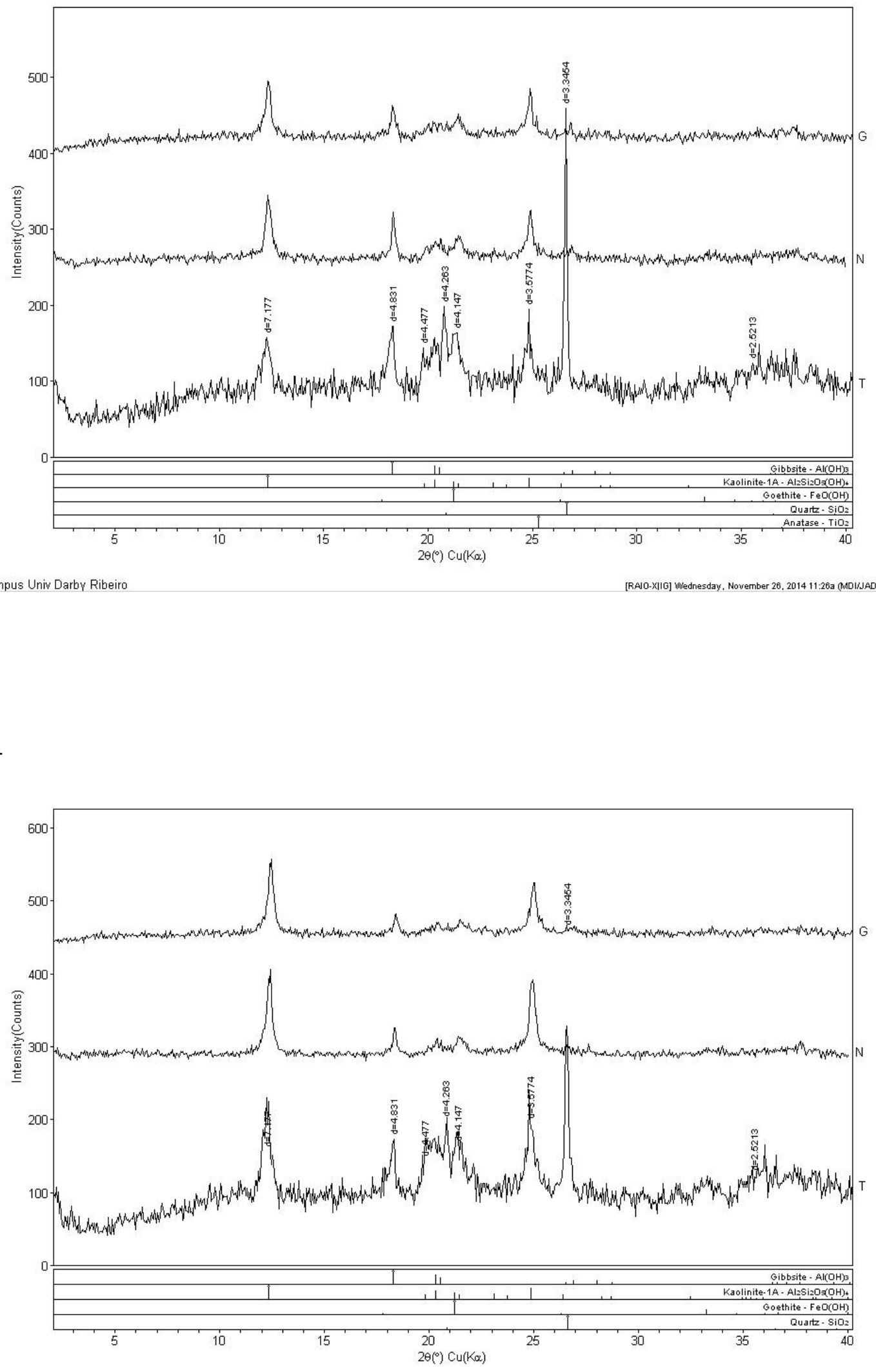

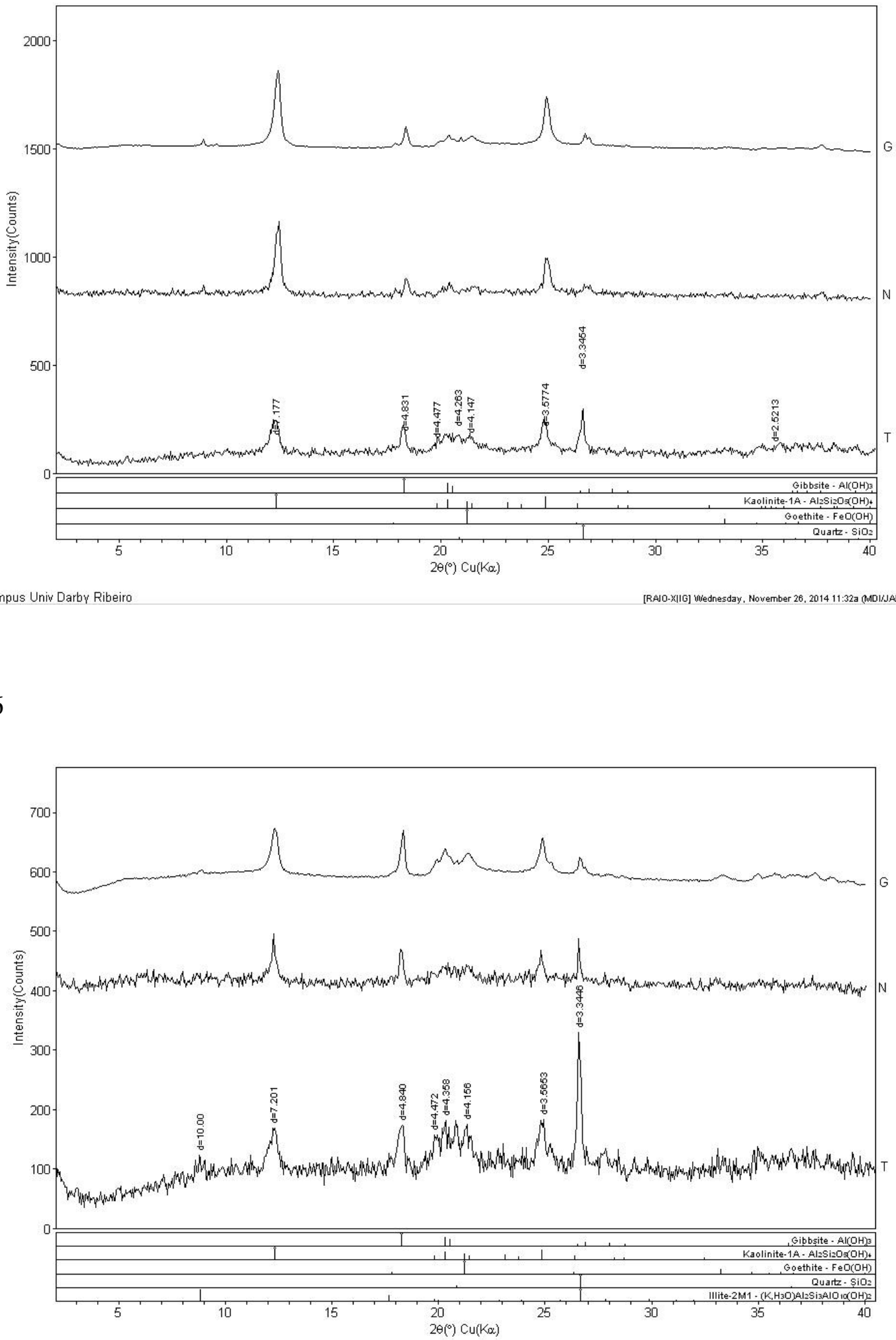

Campus Univ Darby Ribeiro 

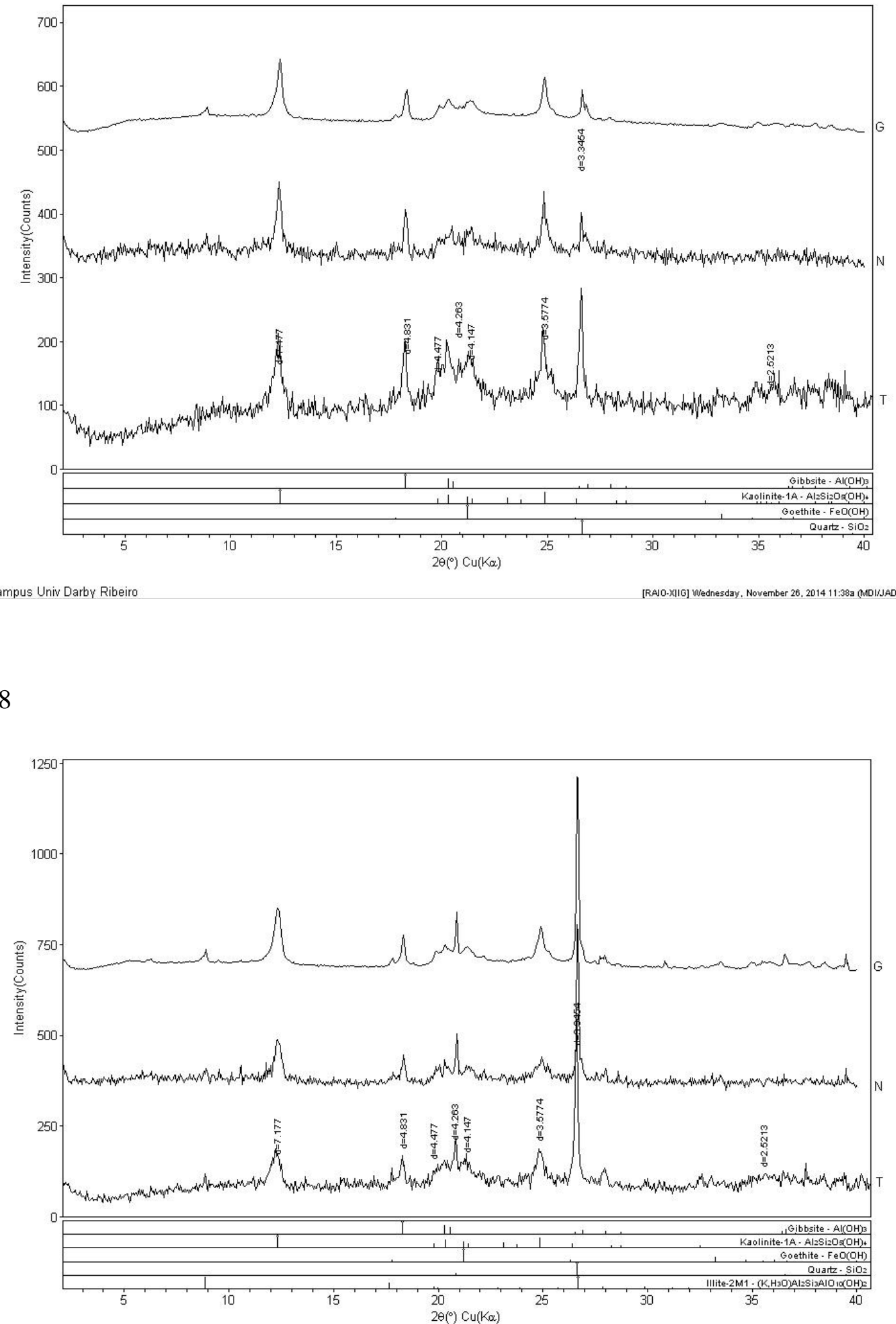

Campus Univ Darby Ribeiro 


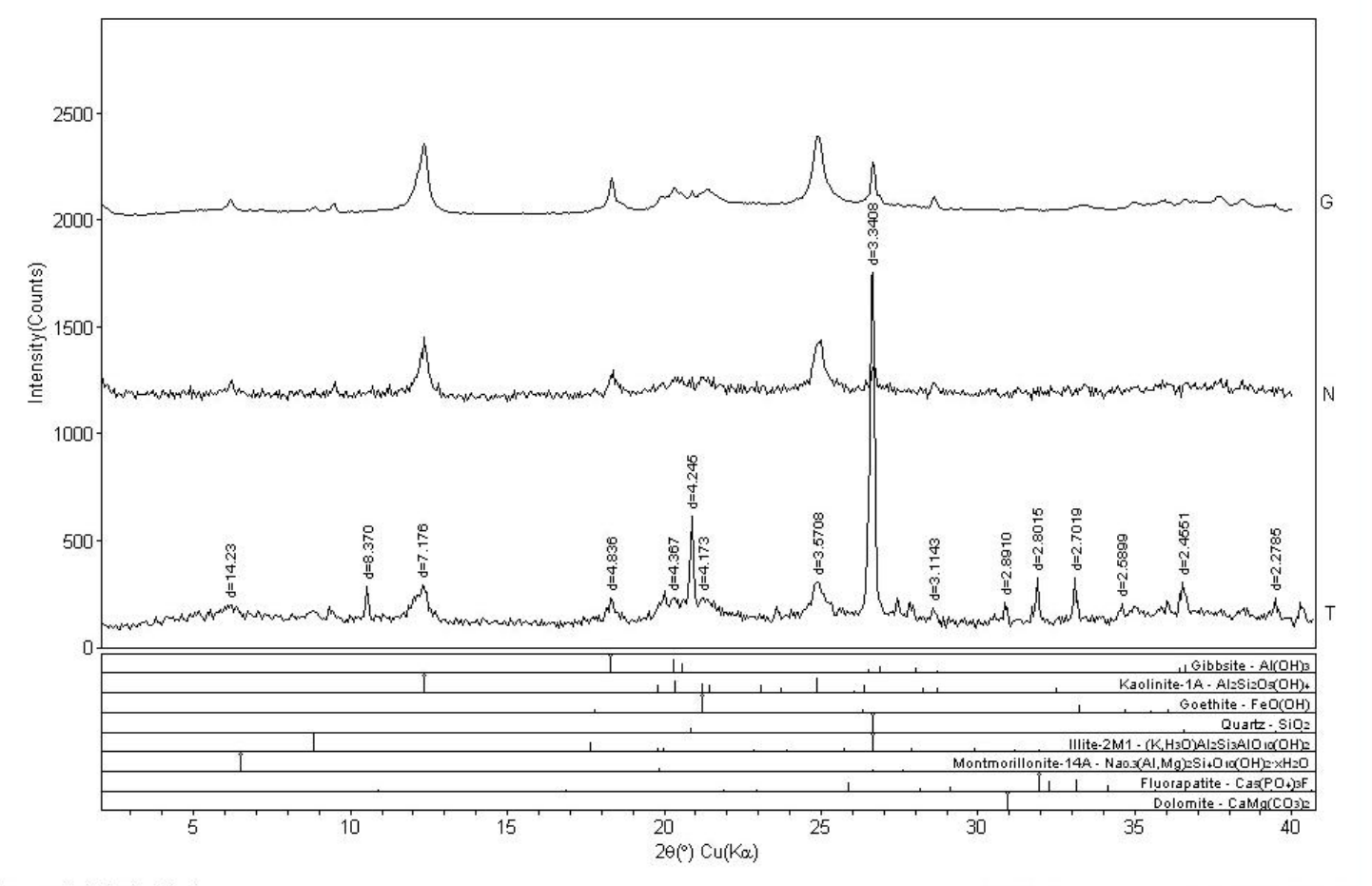

Campus Univ Darby Ribeiro

[RAO-X||G] Wednesday, November 26, 2014 11:43a (MDIJJADE9)

P10

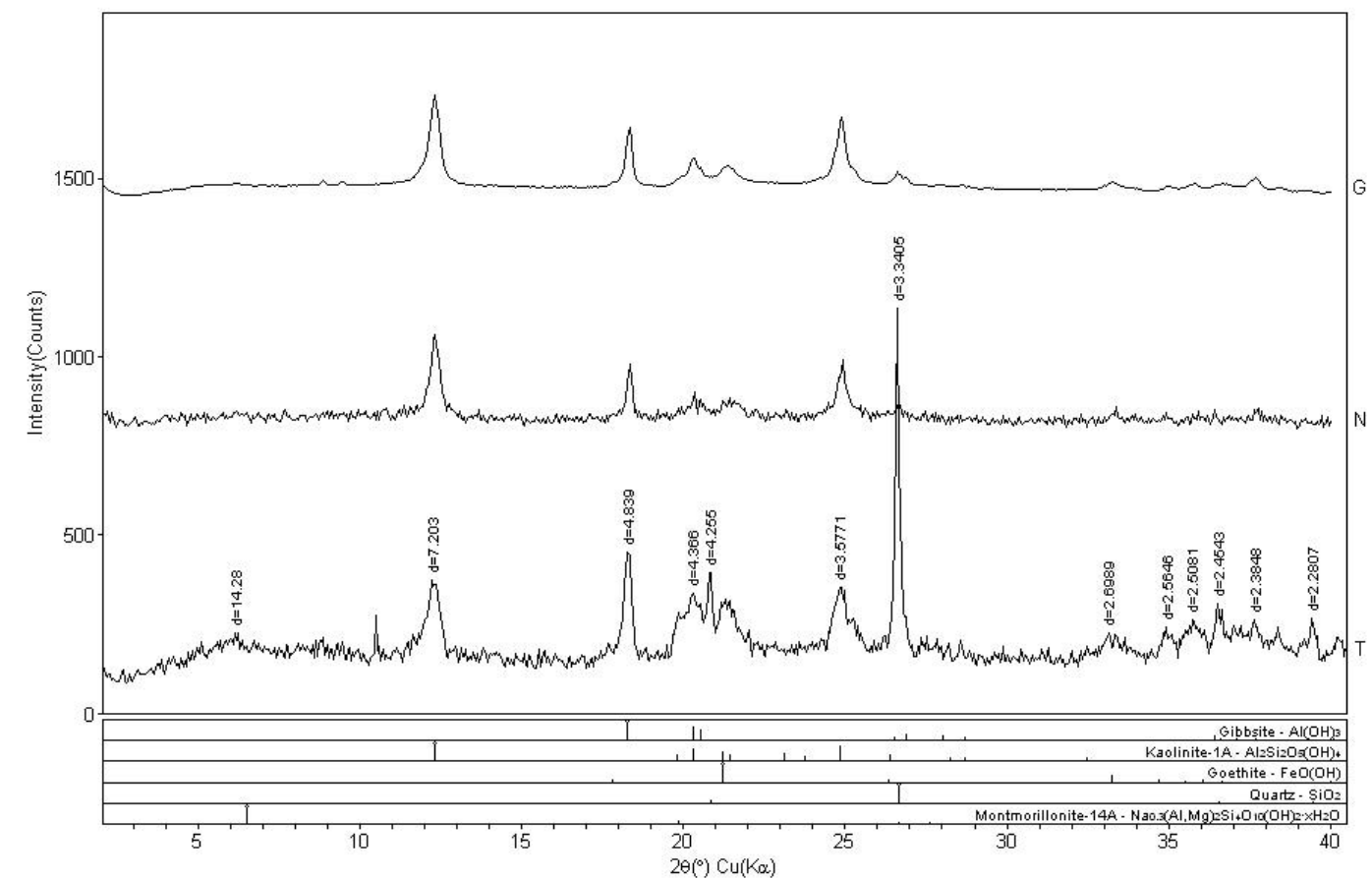

Campus Univ Darby Ribeiro

[RAO-X||G] Wednesday, Nowember 26, 2014 11:44a (MDIJJADE2) 
P11

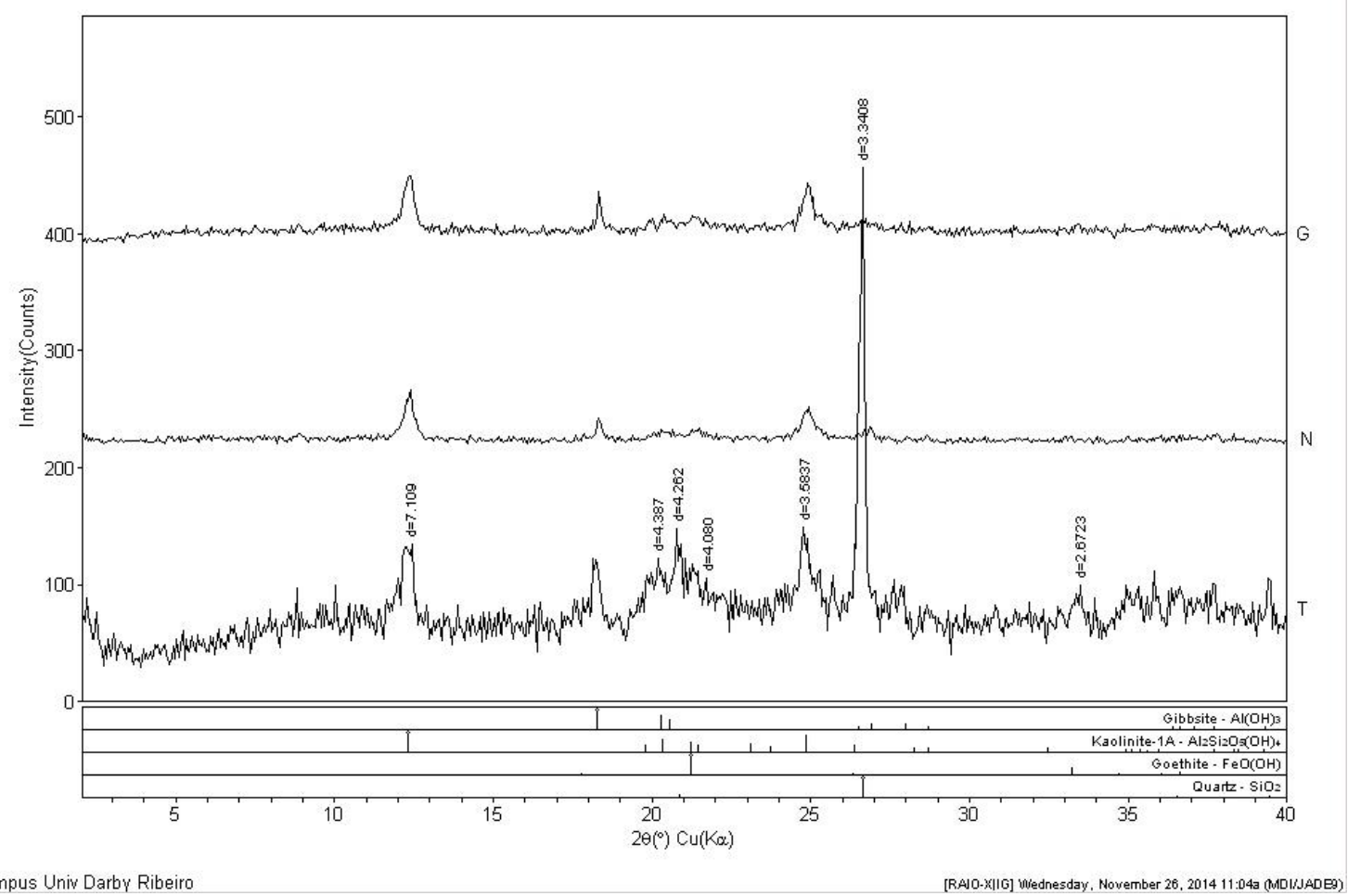

P12

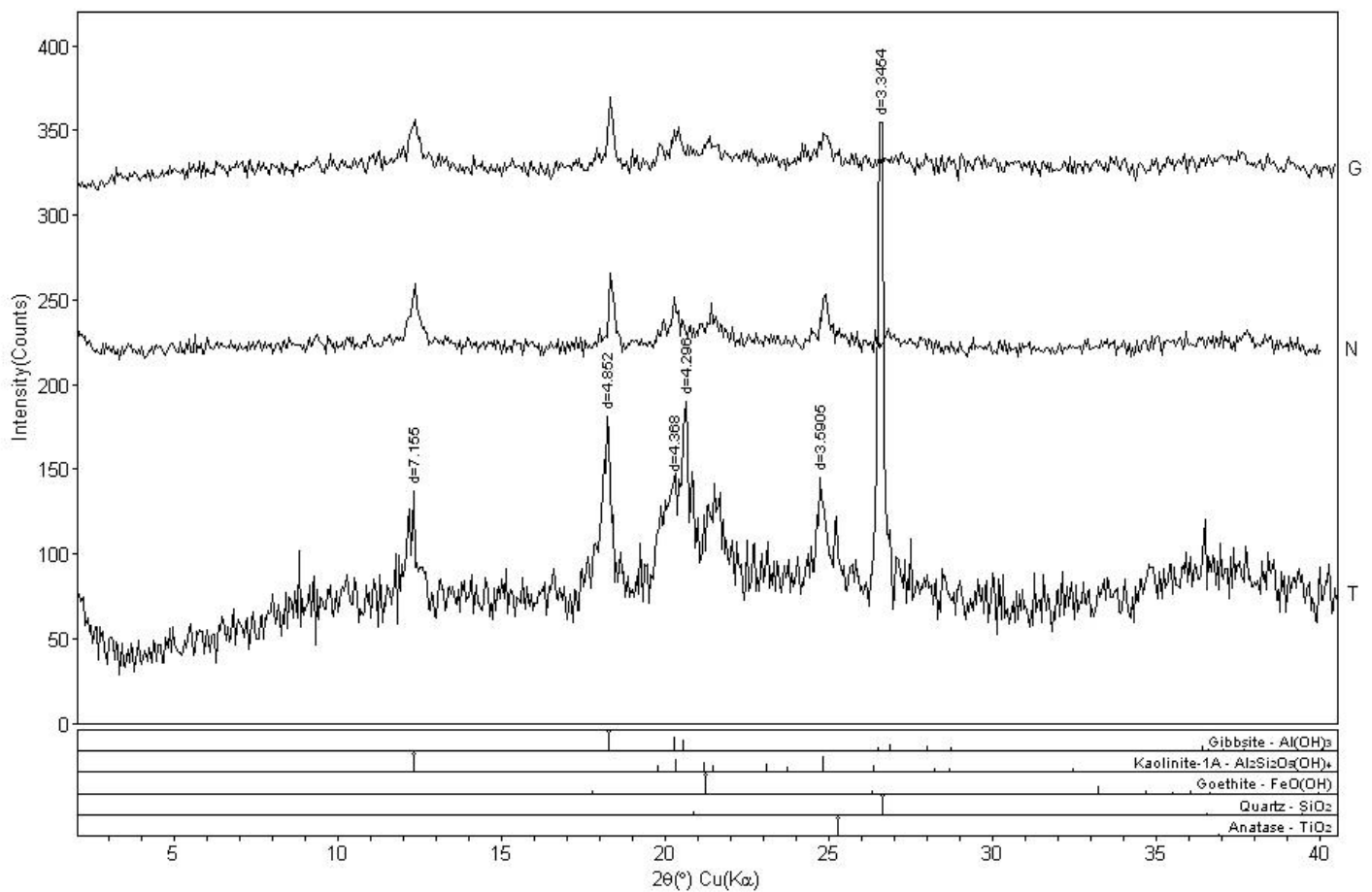

Campus Univ Darby Ribeiro

[RA0-X||G] Wednesday, November 26, 2014 11:03a MDIJJADES 
P13

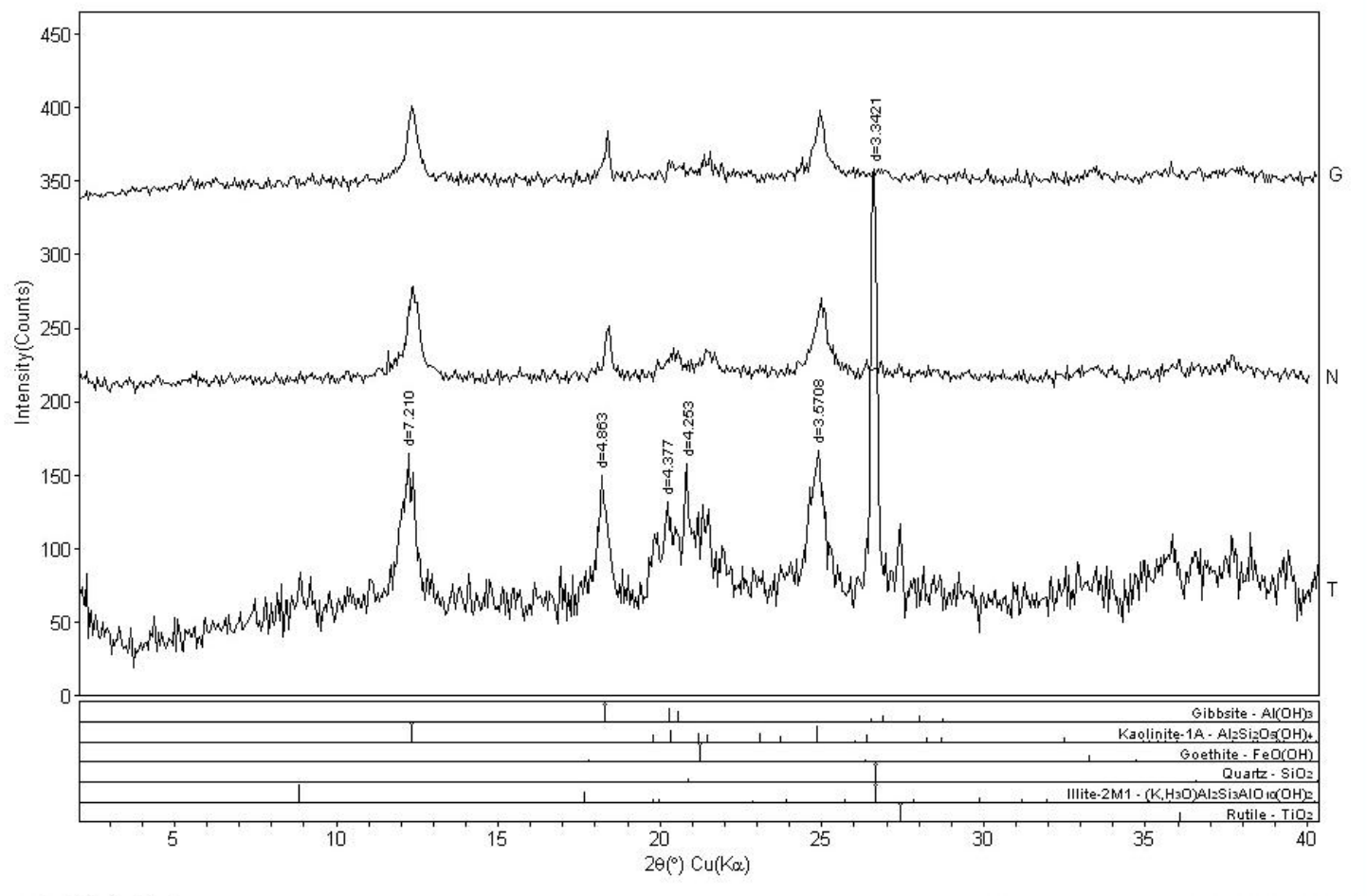

Campus Univ Darby Ribeiro

[RADO-X||G] Wednesday, November 26, 2014 11:00a (MDIJJADE?)

P14

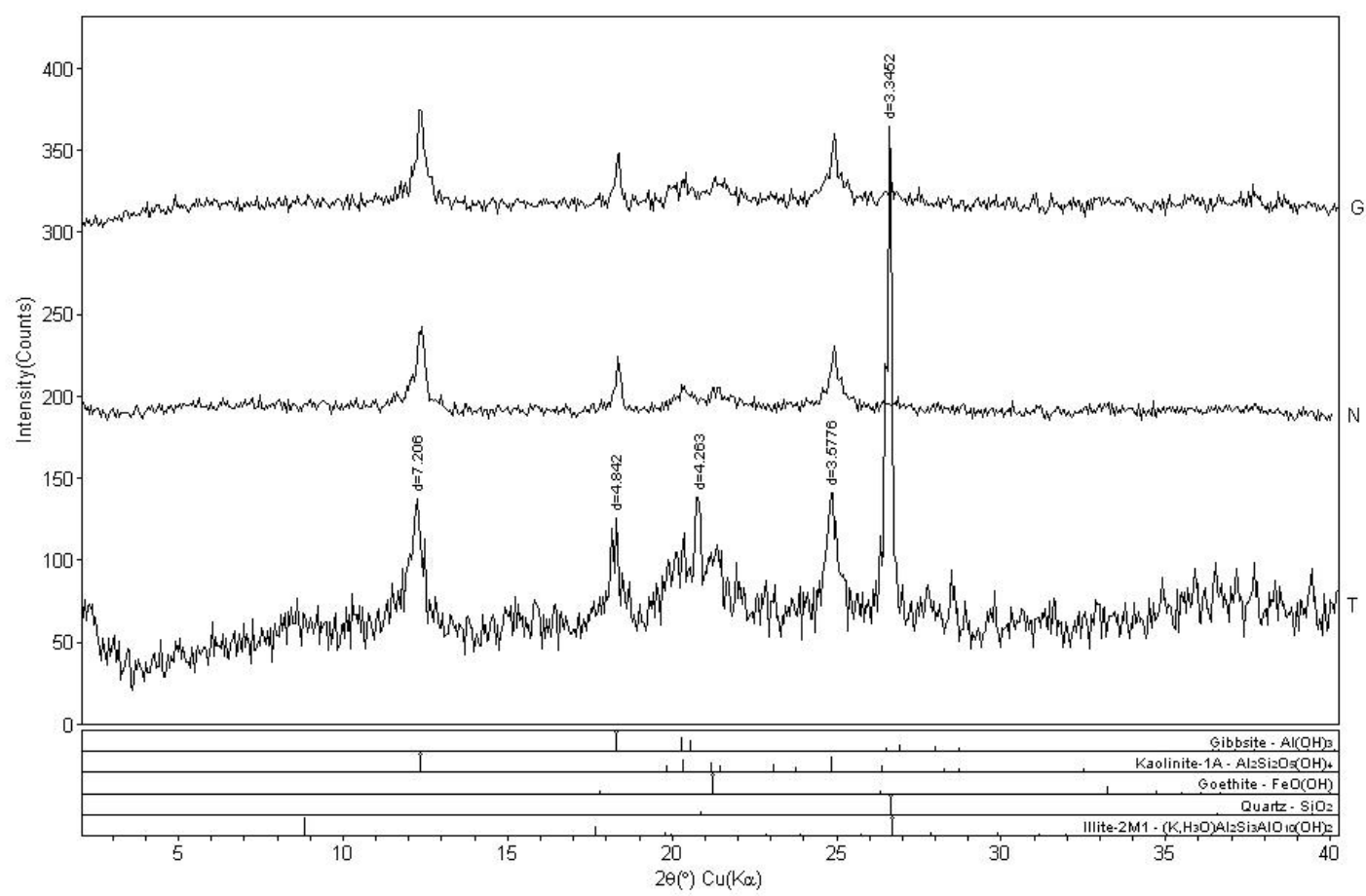

Campus Univ Darby Ribeiro

[RAlO-XIIG] Wiednesday, November 26, 2014 10:58a (MDIJADE9) 


\section{P15}

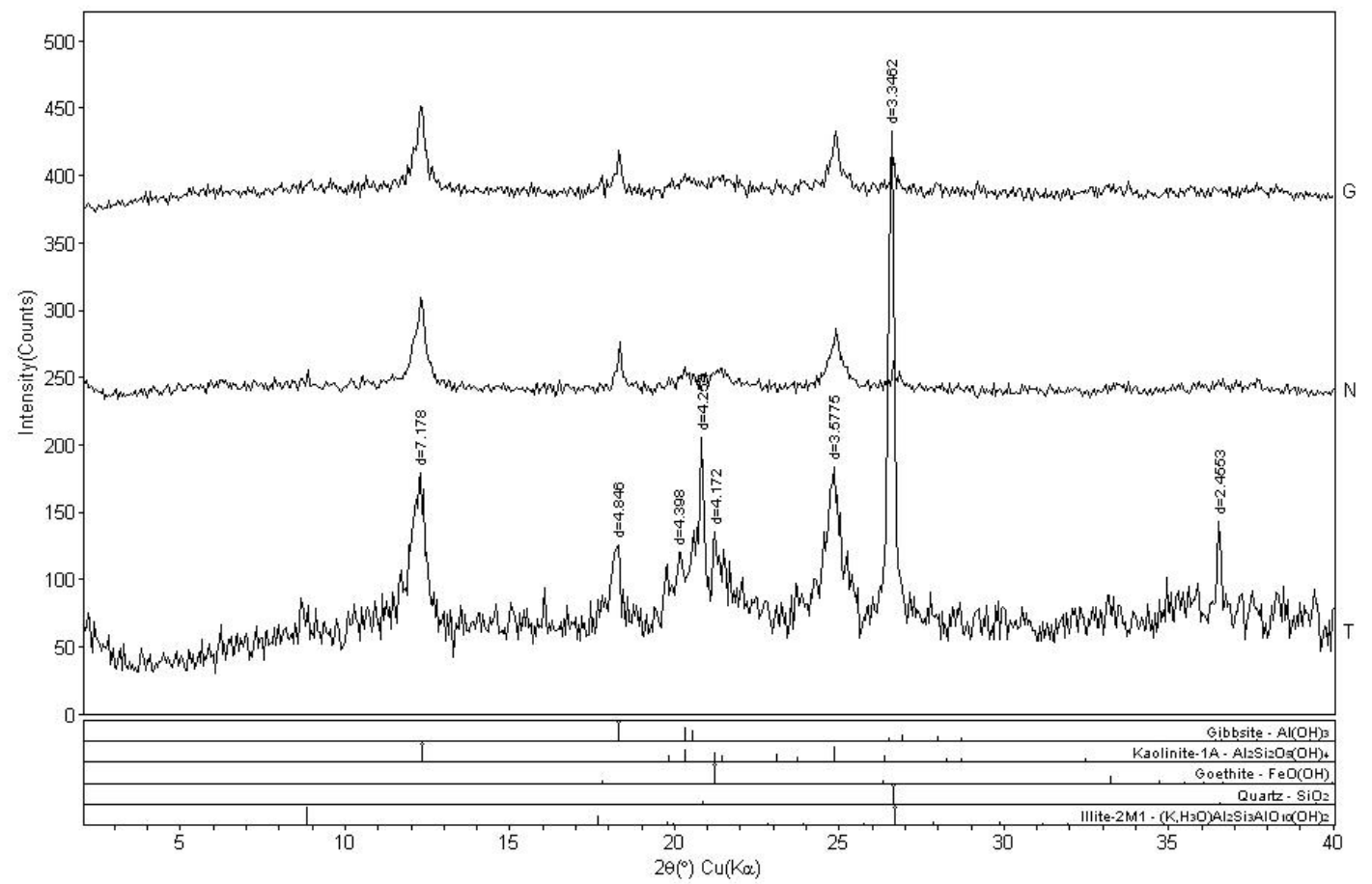

Campus Univ Darby Ribeiro

[RAN0-X||G] Wednesday, November 26, 2014 10:51a (MDIJAADE9)

P16

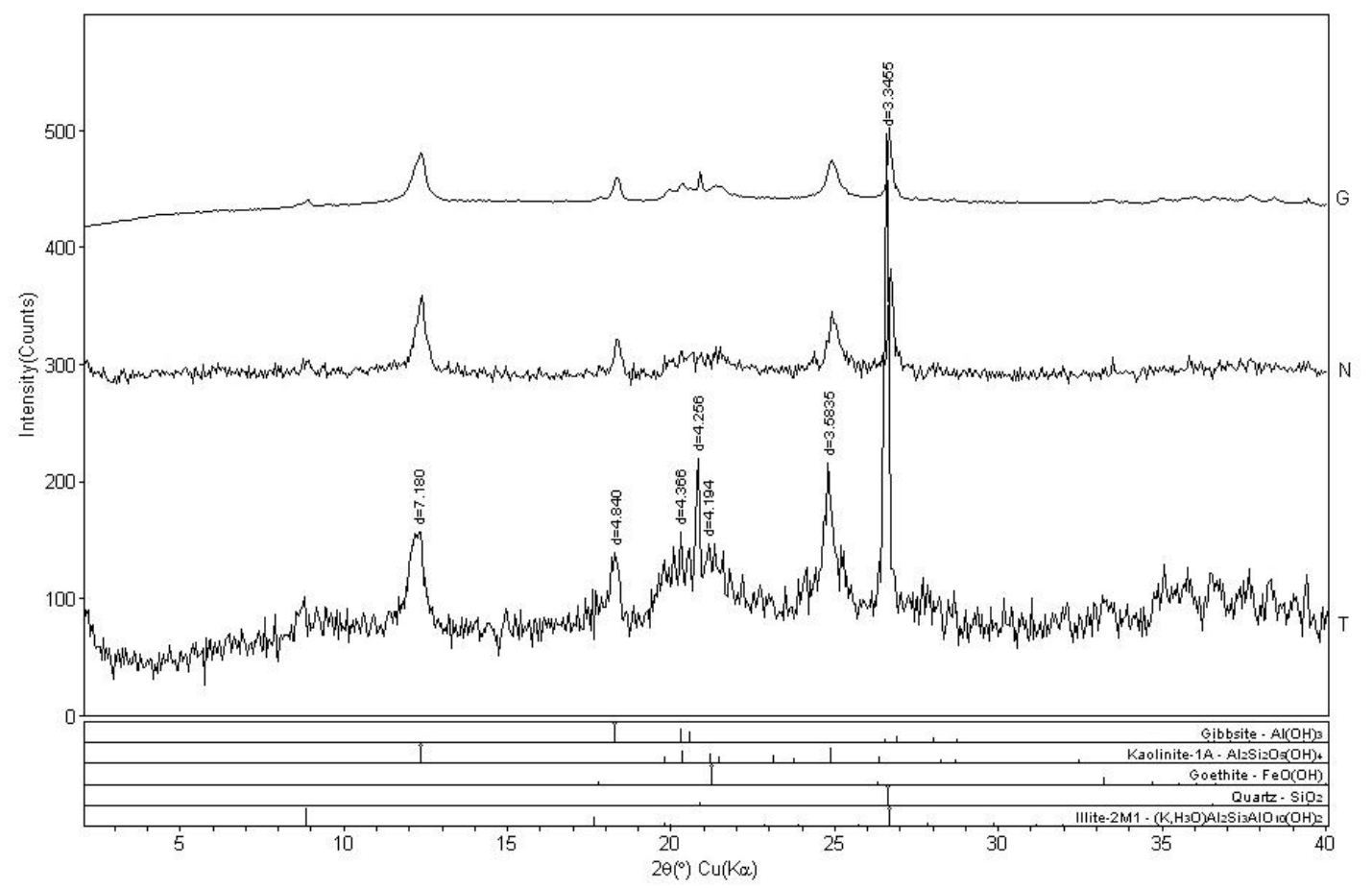

Campus Univ Darby Ribeiro

[RAO-X||G] Wiednesday, Norember 26, 2014 10:49 a MDIJADE 


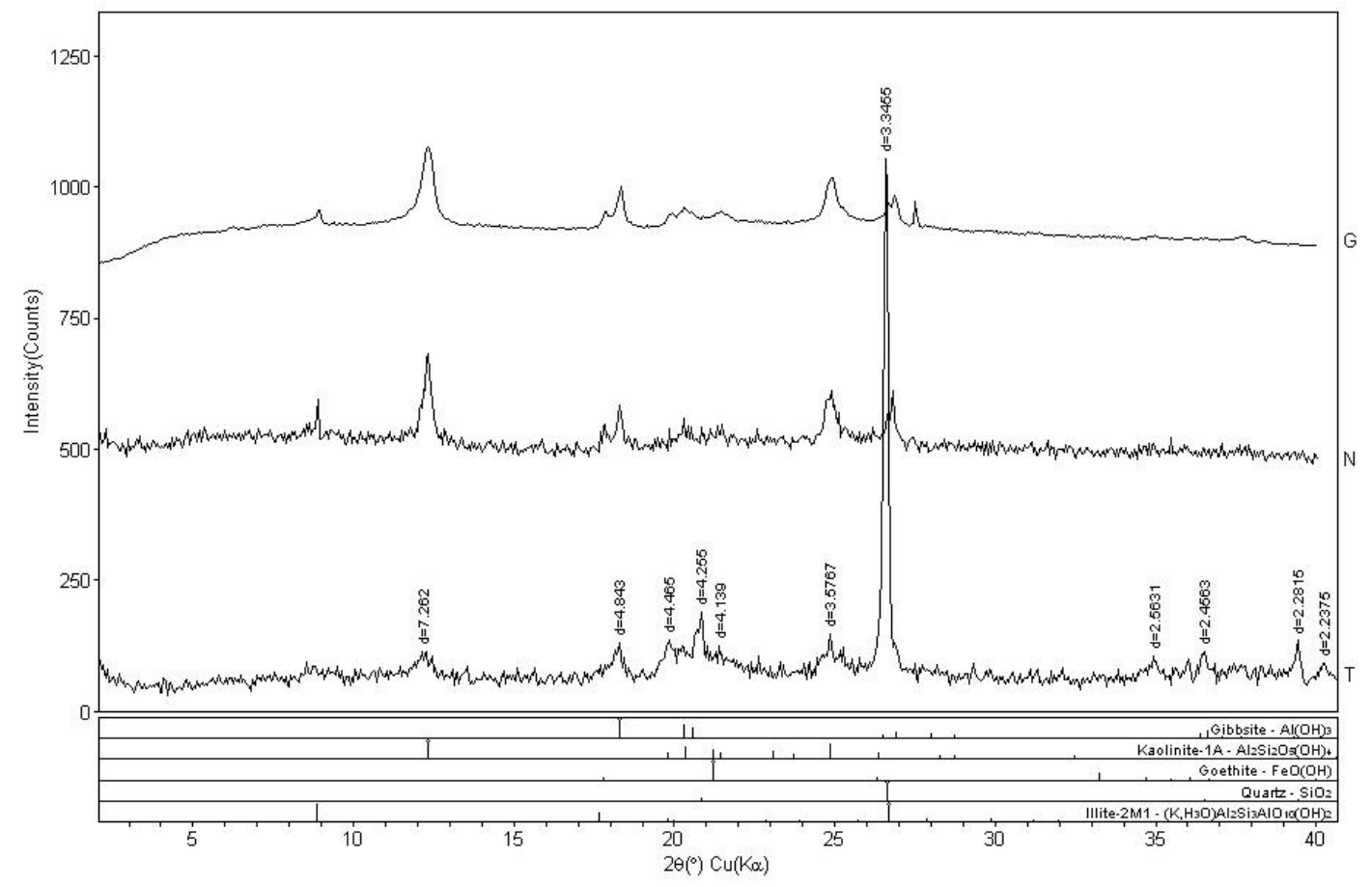

Campus Univ Darby Ribeiro

\section{P18}

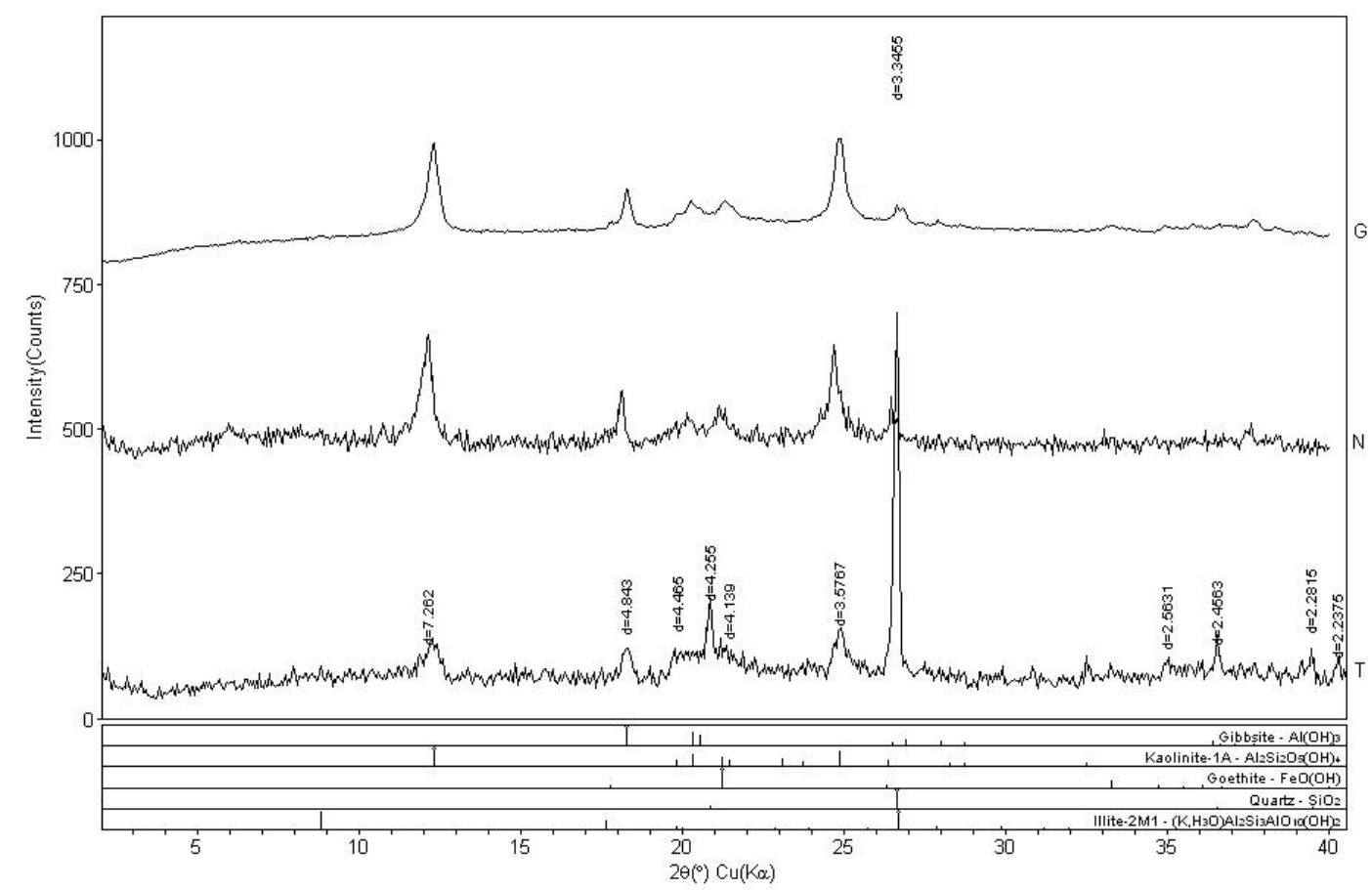




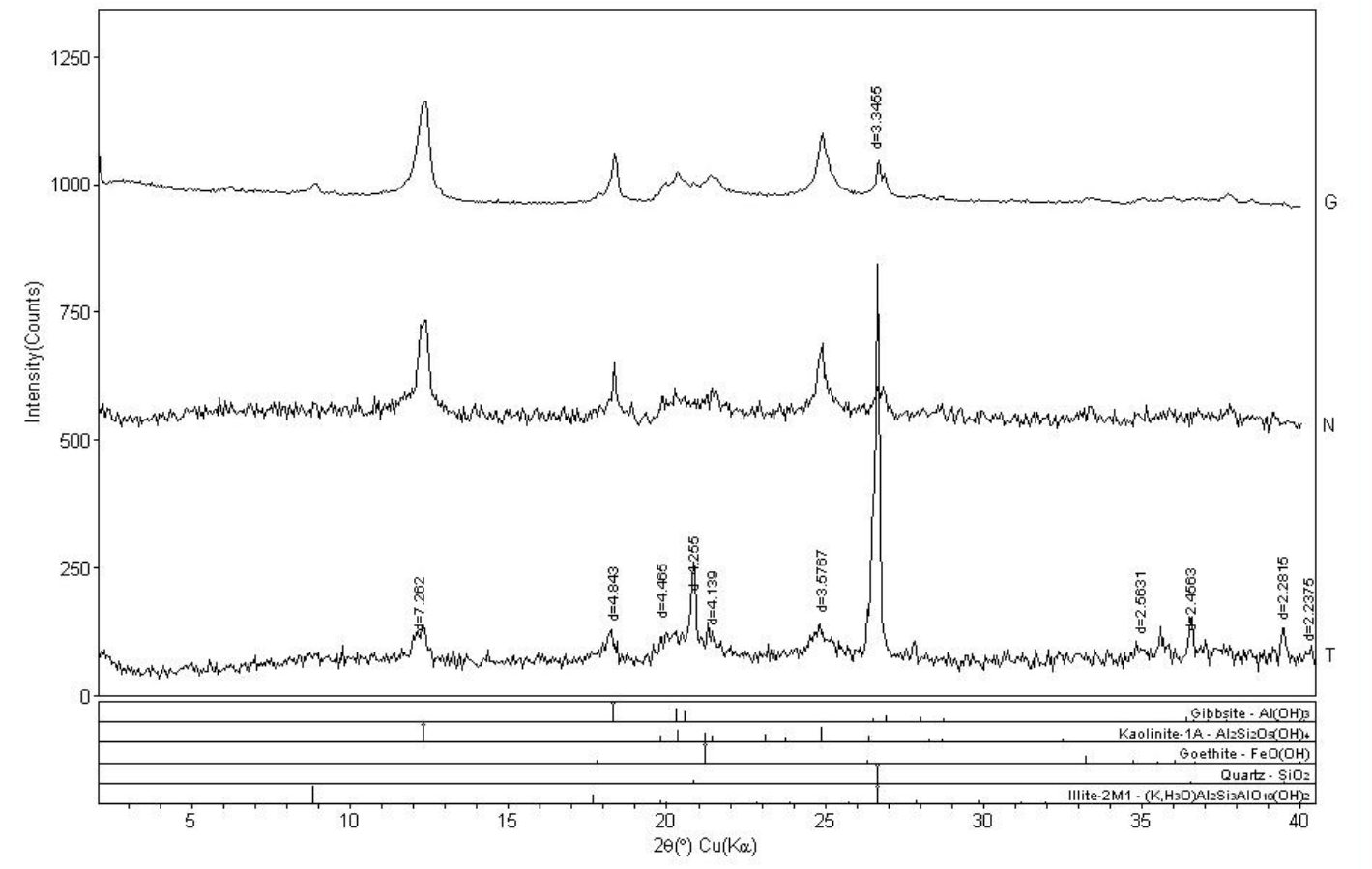

Campus Univ Darby Ribeiro

[RAOO-XIIG] Wednesday, November 26, 2014 10:39a (MDIJJADE9)

P20

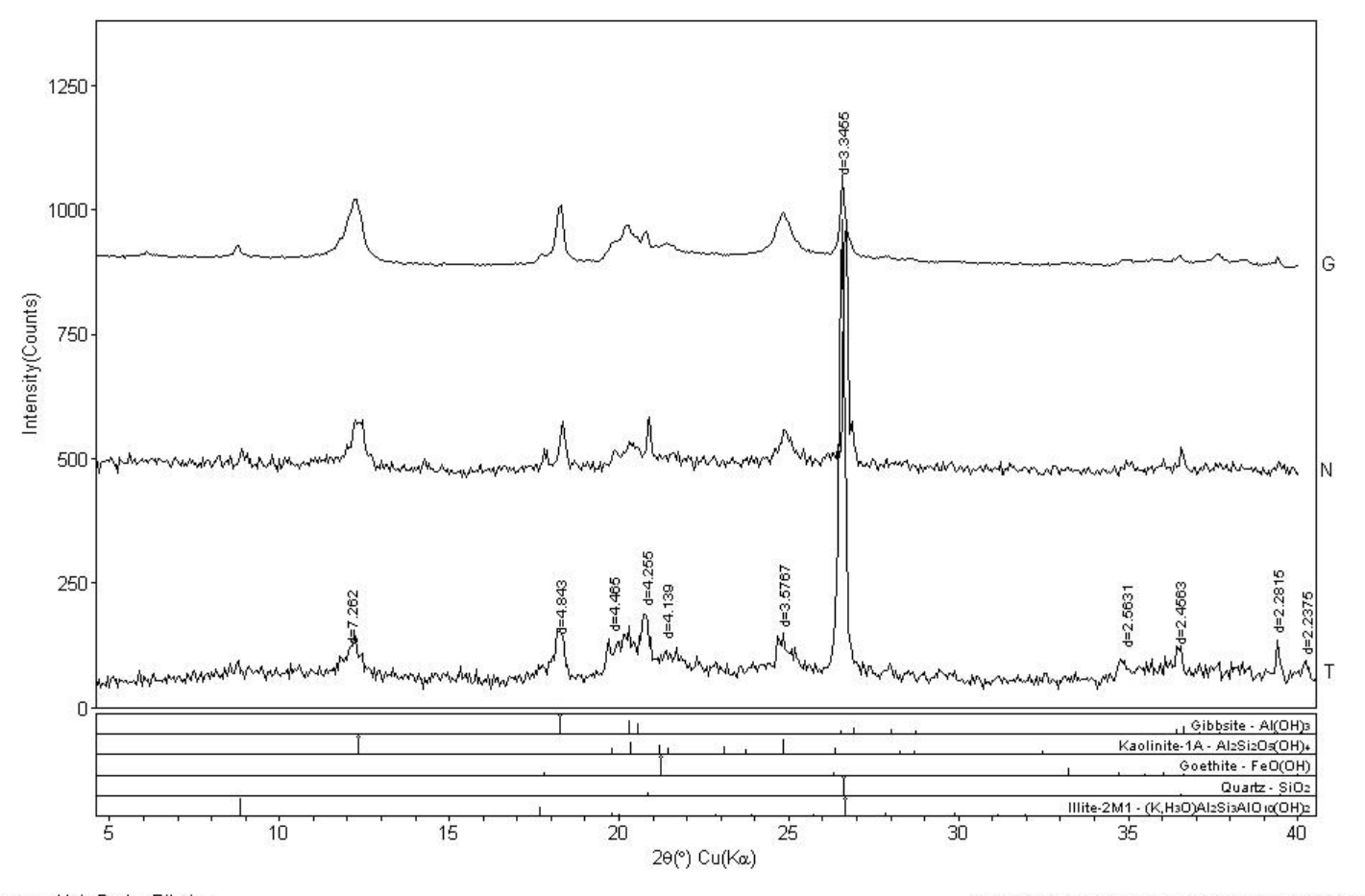

Campus Univ Darby Ribeiro

[RA10-XIIG] Wednesday, November 26, 2014 10:34a MDIJJADE9) 


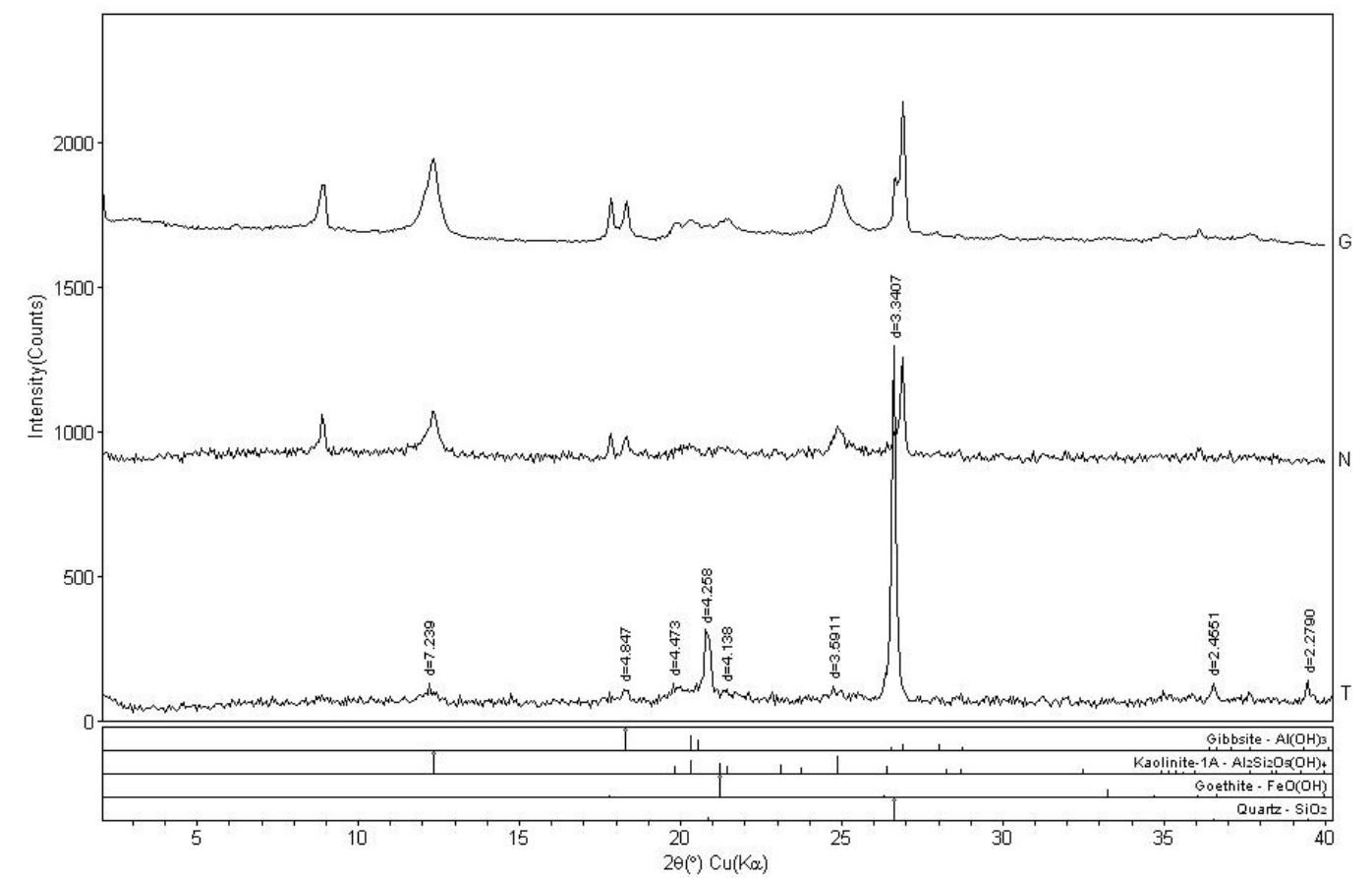

Campus Univ Darby Ribeiro

\section{$\mathrm{P} 22$}

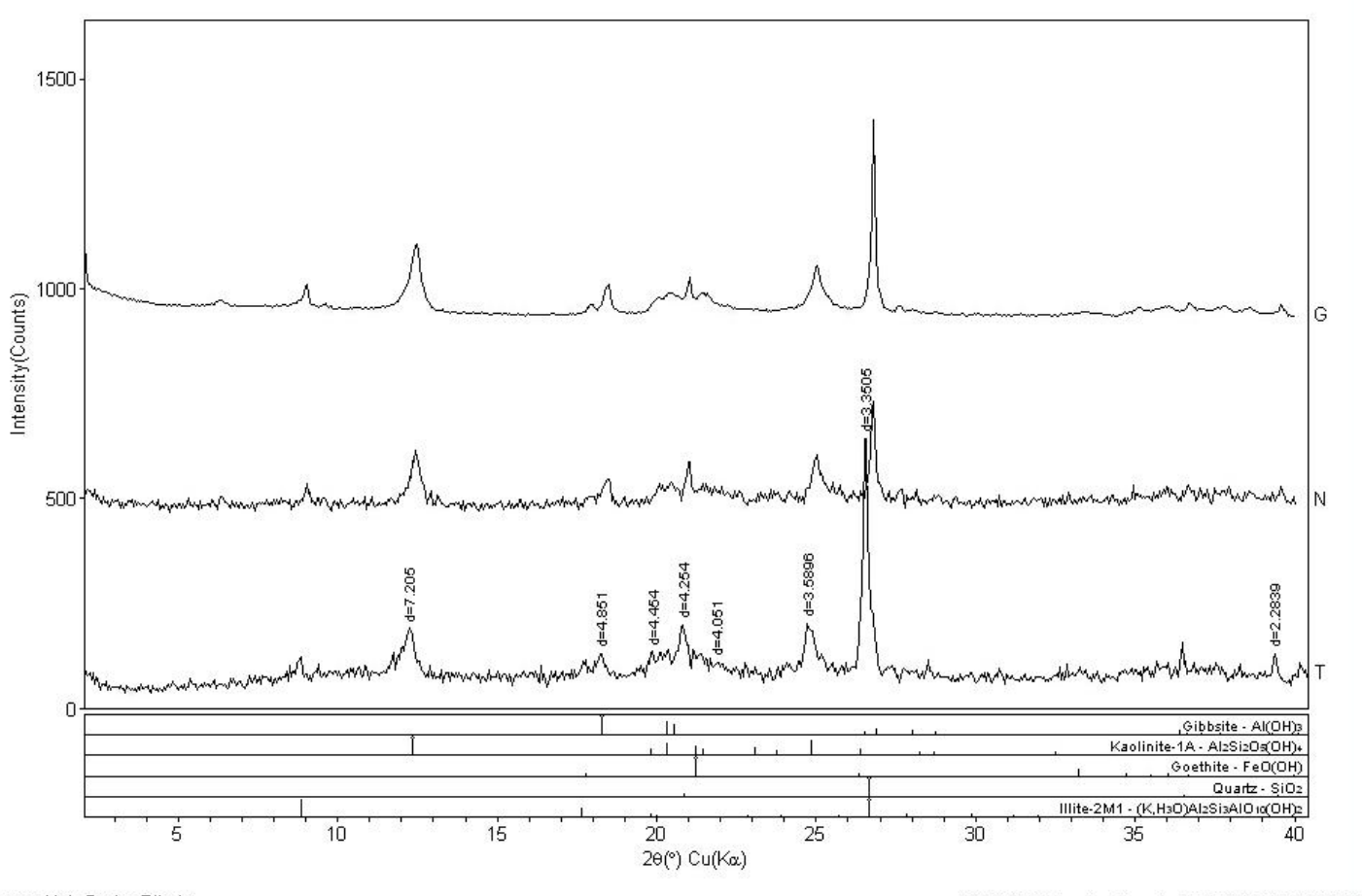

Campus Uniw Darby Ribeiro

[RAOO-X|IG] Wednesday, November 26, 2014 10:14a (MDI/JADEQ) 